CAmila AKemi Perruso

\title{
O DESAPARECIMENTO FORÇADO DE PESSOAS NO SISTEMA INTERAMERICANO DE DIREITOS HumANOS - DiREITOS HumANOS E MEMÓRIA
}

\author{
DISSERTAÇÃO DE MESTRADO \\ ORIENTAdORA: Prof ${ }^{a}$. CLÁUdiA PERRONE-MoISÉS
}

FACUldade de DiReito da Universidade de SÃo PaUlo

SÃO PAULO

2010 
CAmila AKemi Perruso

\section{O DESAPARECIMENTO FORÇADO DE PESSOAS NO SISTEMA INTERAMERICANO DE DIREITOS Humanos - DiReitos Humanos E MEMóRIA}

DISSERTAÇÃO APRESENTADA À FACULDADE DE DIREITO DA USP, COMO REQUISITO PARCIAL PARA A OBTENÇÃO DO TÍTULO DE MESTRE EM DIREITO

Área de CONCENTRAÇÃO: DiREITO INTERNACIONAL

Orientadora: Profa. CláUdia PERRONEMOISÉS

FACUldade DE DiREITo dA UniversidAde de São PAUlo 2010

SÃo PAULO 
Banca Examinadora:

-

——— - -


Aos familiares de desaparecidos, pela coragem. 


\section{AgradeCimentos}

À professora Cláudia Perrone-Moisés, que, com sua generosidade e seu exemplo, me ensina todos os dias os bons passos a se trilhar como ser humano. Para Hannah Arendt, o mestre é aquele que ajuda seus discípulos a tornarem-se eles mesmos, e é isso que faz a professora Cláudia, com amor. Agradeço-a pela confiança, pelo respeito, pela oportunidade, desejando continuar sua discípula por toda a vida.

A minha mãe, Liris Nakagawa, que por toda a vida me impulsiona para o mundo, acolhe meus medos e me incentiva a transbordar as alegrias. Ao meu pai, Valdir Perruso, não só por todo apoio e compreensão, mas especialmente porque juntos construímos um porto seguro onde nunca nos sentiremos sozinhos.

A minha irmã, Fernanda Perruso, que com sua sabedoria me acalma, e comigo compartilha a existência, quase como uma só vida. Ao meu irmão, Rodolfo Perruso, pois nossos entusiasmos e admiração só crescem.

A minha obatchan, Matsuko Nakagawa, pela linda vida que fez. Aos meus amados tios, ao Roberto pelo sempre cuidado, ao Hiroo e a Leonor, pela gentileza. Ao Eduardo e ao Mateus, pela esperança.

Às irmãs que escolhi na vida; a Mariana Oliveira e a Melissa Migliori, por me mostrarem, cada uma a seu jeito, a potência de existir, a Thana Campos e a Cecilia Oliverio, pela doçura, e por me acolherem como nunca poderia supor.

Às amadas Bruna Charifker e Maitê Gauto pela compreensão incondicional, e por me ajudarem a entender o significado da amizade. Às lindas amigas Akemi Kamimura, Estela Guerrini, Fernanda Fernandes e Julia Neiva, pelos sonhos compartilhados. A Adriana Zacchi e a Letícia Massula, que me acompanham no colorido da vida. À querida Rosana Monnerat, pelo carinho. Ao Fabrício Toledo, pela companhia da vida inteira. 
Aos amigos do TGB, especialmente ao Carlos Buby, ao Djalma Scartezini, a Juliana Porto, a Laura Correa, ao Luê Prado, a Márcia Murari, ao Ricardo Hida e ao Rodrigo Vieira, por me ajudarem a escolher os meus caminhos.

Aos amigos do LInC, Max Alvim, Ricardo Teixeira, Rogério da Costa, Rubens Kignel, Tuto Souza e Vera Mendes, pelos bons e alegres encontros.

Aos amigos do GVlaw, Aline Sanches, Fabia Veçoso, Karina Brazil, Leandro Pereira e Marina Feferbaum, pela intensa aprendizagem. Aos queridos do IBCCRIM, Bruno Shimizu, Fernanda Araújo e Gabriel Berla, pelo respeito mútuo.

À delicada Edna, pelas risadas e pelo carinho. Ao professor Guilherme Assis de Almeida, pelas oportunidades, pelo entusiasmo que me inspira e comunica ao mundo. Ao professor André de Carvalho Ramos, pelas valiosas contribuições na banca de qualificação.

Ao Sasakawa Young Leaders Fellowship Fund (SYLFF), representado pelos professores Adalberto Fischmann, Carlos Azzoni e João Grandino Rodas, e pela Malu do CCInt/USP, pelo apoio e incentivo à pesquisa. 
Ninguém fará crescer uma Lembrança

Que as Raizes perdeu Querer socar o Solo em sua volta

E em estacas erguê-la Pode enganar o Mundo - mas a planta Não se renovará Essa Memória, como os Pés do Cedro, Na Pedra é que se calçaNem se pode matar uma Lembrança Que já se arraigou Os seus Brotos de Ferro dispersados

Florescerão de novo -

(Emily Dickinson) 


\section{RESUMO}

No marco do direito internacional dos direitos humanos, a presente dissertação de mestrado analisa o desaparecimento forçado de pessoas, que, em razão de constituir grave violação de direitos humanos, foi tipificado crime contra a humanidade. Desse modo, tem por fim verificar o surgimento desse fenômeno nos regimes ditatoriais da América Latina, e o tratamento dispensado a ele pela comunidade internacional, observando-se a interdependência de ramos do direito internacional face ao desaparecimento. Ademais, visa a fazer uma aproximação entre memória e direitos humanos, temática intrinsecamente relacionada com o desaparecimento forçado de pessoas. Nessa perspectiva, apresenta uma análise dos casos de desaparecimento julgados pela Corte Interamericana de Direitos Humanos com vistas à sua compreensão acerca do direito à verdade, extraindo-se a afinidade desse direito com a construção de memórias. Dessa maneira, este estudo considera a relação direta entre a manipulação de memórias do passado, pelo ocultamento dos fatos relativos a crimes da natureza do desaparecimento forçado, e as violações de direitos humanos que ocorrem no presente.

Palavras-Chave: desaparecimento forçado de pessoas, direitos humanos, direito internacional, crime contra a humanidade, Corte Interamericana de Direitos Humanos, direito à verdade, memória, ditadura, democracia. 


\section{Abstract}

Within the framework of international human rights, this thesis analyzes the enforced disappearance of persons, which was typified as a crime against humanity due the fact of being a serious violation of human rights. Thus, it aims to determine the emergence of this phenomenon during dictatorial regimes in Latin America, and its treatment by the international community, emphasizing the interdependence between different international law branches to the disappearance. Moreover, it aims to make a connection between memory and human rights, a theme closely linked to enforced disappearance of persons. Through this perspective, it presents an analysis of disappearance cases judged by the Inter-American Court of Human Rights in order to depict its understanding about the right to the truth, extracting the affinity of this right with the construction of memory. Accordingly, this study considers the relationship between the manipulation of memories about the past through the concealment of facts related to enforced disappearance crimes, and ongoing human rights violations.

KEY-WORDS: enforced disappearances of persons, human rights, International Law, crime against humanity, right to the truth, memory, dictatorship, democracy. 


\section{Lista de AbREVIATURAS}

DUDH - Declaração Universal dos Direitos Humanos

ONU - Organização das Nações Unidas

OEA - Organização dos Estados Americanos

TPI - Tribunal Penal Internacional 


\section{ÍNDICE}

RESUMO …

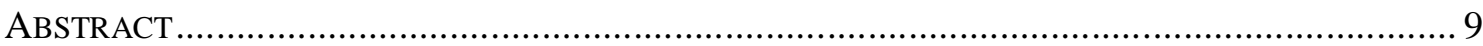

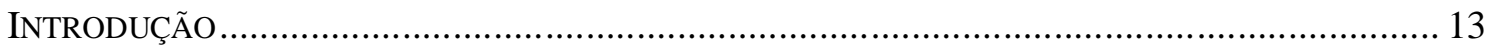

1. CONSTRUÇÃO HISTÓRICA E NORMATIVA DO CRIME DE DESAPARECIMENTO FORÇADO DE

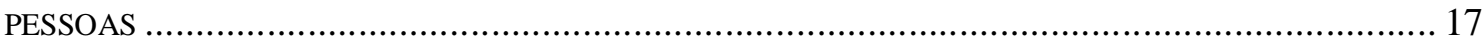

1.1. O fenômeno do desaparecimento forçado de pessoas ................................................. 17

1.2. Histórico da normativa internacional para proteção contra o desaparecimento forçado de pessoas no Direito Internacional …………………………..................................... 23

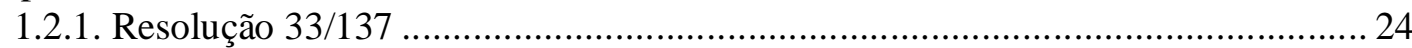

1.2.2. Declaração sobre a Proteção de Todas as Pessoas contra o Desaparecimento

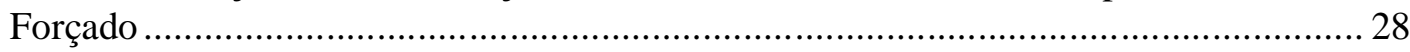

1.2.3. Convenção Interamericana sobre Desaparecimento Forçado de Pessoas................ 32

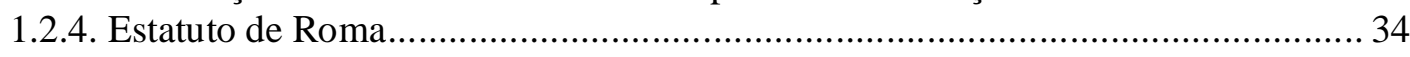

1.2.5. Convenção Internacional para Proteção de Todas as Pessoas contra o

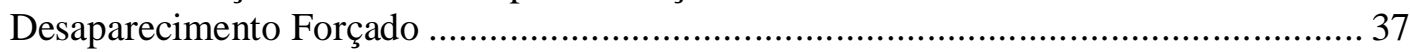

1.3 A contribuição do grupo de trabalho sobre desaparecimento forçado ou involuntário de

pessoas da ONU e das organizações não-governamentais................................................ 38

1.3.1. O grupo de trabalho sobre desaparecimento forçado ou involuntário da ONU ..... 40

1.3.2. O estabelecimento e a atuação do grupo de trabalho, sua relação com os Estados e

as organizações não-governamentais ......................................................................... 41

2. INTERDEPENDÊNCIA DE RAMOS DO DIREITO INTERNACIONAL PÚBLICO EM RELAÇ̃̃O AO

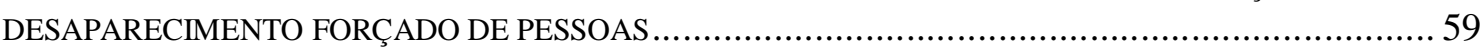

2.1. O direito internacional humanitário e o desaparecimento de pessoas.............................59

2.2. O direito internacional dos direitos humanos e o desaparecimento forçado ou

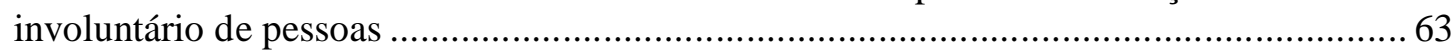

2.3. O direito internacional penal e o desaparecimento forçado de pessoas ......................... 73

2.4. Interdependência dos ramos do direito internacional público ........................................ 80

3. DIREITO À VERDADE E OS CASOS DE DESAPARECIMENTO DA CORTE INTERAMERICANA DE

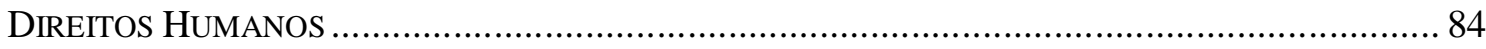

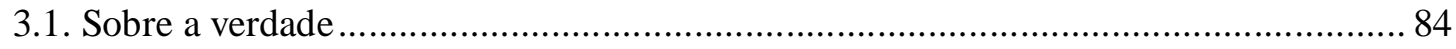

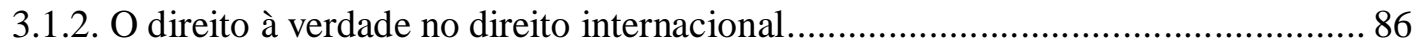

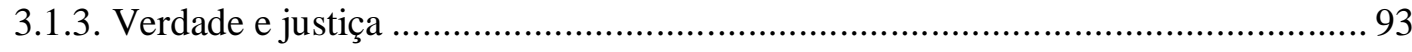

3.2. Os casos de desaparecimento da Corte Interamericana de Direitos Humanos e o direito

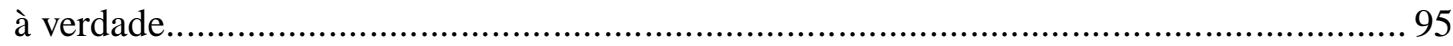

3.2.1 A Corte Interamericana de Direitos Humanos e as Reparações em caso de graves violações de direitos humanos .................................................................................. 95

3.2.2. Os casos da Corte Interamericana de Direitos Humanos de desaparecimento forçado de pessoas e o direito à verdade ………………………….............................. 99

3.2.3. O caso brasileiro na Corte Interamericana de Direitos Humanos ........................ 124

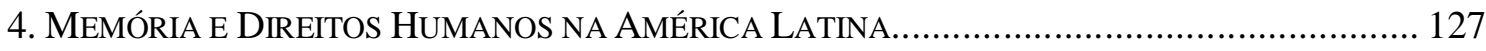

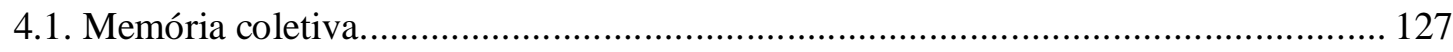

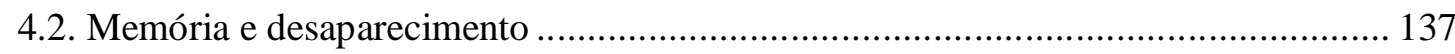

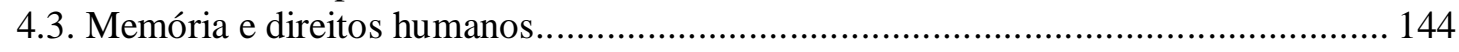


CONCLUSÃO

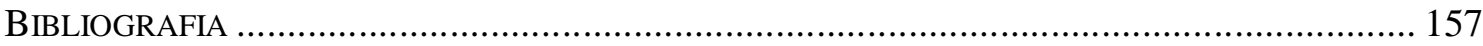

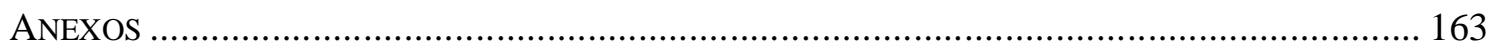




\section{INTRODUÇÃO}

A presente dissertação situa-se no âmbito do direito internacional dos direitos humanos e sua relação com a memória, colocada em relevo pela questão do desaparecimento forçado de pessoas e seus desdobramentos enquanto grave violação de direitos humanos. Dessa maneira, localiza-se no marco de um direito internacional de construção mais moderna, para dialogar com Perrone-Moisés, "que, dando relevância à proteção dos direitos humanos, se insere no campo dos valores compartilhados pela comunidade internacional."1

Considerando que o desenvolvimento dos direitos humanos no âmbito de tutela do direito internacional baseia-se especialmente na necessidade de proteção das pessoas face às atrocidades cometidas durante a política totalitária nazista, com o fim de evitar que aqueles atos pudessem novamente ser cometidos contra a humanidade, compreende-se que "a rememoração também significa uma atenção precisa ao presente, em particular a estas estranhas ressurgências do passado no presente, pois não se trata somente de não se esquecer do passado, mas também de agir sobre o presente. ${ }^{2,}$

Dessa forma, um dos objetivos do direito internacional dos direitos humanos é a instituição de patamares mínimos para a convivência humana, na perspectiva de que determinados atos do passado não são mais tolerados no presente. E é nesse esteio que se insere o desaparecimento forçado de pessoas, descrito por Perrone-Moisés da seguinte maneira:

\footnotetext{
Violações particularmente odiosas dos direitos humanos, os desaparecimentos forçados constituíram prática nos países latino-americanos durante as ditaduras militares. Ocorridos em larga escala nos anos 60 na Guatemala, deram origem à utilização do termo "desaparecidos" pelas famílias das vítimas que foram seqüestradas, presas, torturadas e muitas vezes mortas, sem que se soubesse do seu paradeiro. Colocados em um lugar onde não são mais protegidos pela lei ou pela sociedade, os "desaparecidos" acabam privados de todo e qualquer direito. Neste sentido, encontram-se naquela situação que Hannah Arendt detectara em relação às vítimas do nazismo: destituídas do "direito a ter direitos", são postas à margem do mundo, tornando-se supérfluas e descartáveis. ${ }^{3}$
}

\footnotetext{
1 PERRONE-MOISÉS, Cláudia. Imunidades de chefes de Estado e crimes internacionais. Tese de Livre Docência apresentada na Faculdade de Direito da USP, 2009, p. 2.

${ }^{2}$ GAGNEBIN, Jeanne Marie. Lembrar escrever esquecer. São Paulo: 34, 2006, p. 55.

${ }^{3}$ PERRONE-MOISÉS, Cláudia. Leis de anistia face ao Direito Internacional: "desaparecimentos" e "direito à verdade". In: PIOVESAN, Flávia (org.). Direitos humanos, globalização econômica e integração regional: desafios do direito constitucional internacional. São Paulo: Max Limonad, 2002, p. 288.
} 
O problema do desaparecimento forçado é motivo de debate da comunidade internacional na atualidade em razão de sua prática ainda ser recorrente em diversas partes do mundo. Ademais, os países da América Latina, onde os desaparecimentos surgiram como instrumento de repressão dos regimes ditatoriais, estão lidando com seus efeitos, à medida que a maioria dos casos de desaparecimento ainda não foram solucionados, e desdobramentos correlatos relativos às anistias, à possibilidade de punição dos responsáveis, à reparação às vítimas e aos familiares, ao direito à verdade, à construção das memórias etc, estão na ordem do dia.

Dessa maneira, essa questão está na pauta do debate jurídico internacional por se constituir uma violação multifacetada de direitos humanos e em razão disso ser tipificado crime contra a humanidade, rompendo com a clássica acepção acerca do dever do Estado de garantir a liberdade e segurança de seus cidadãos, pois este crime acontece pela ação ou aquiescência de suas instituições ou/e agentes. Assim, o desaparecimento forçado de pessoas levanta questões para o direito internacional que dizem respeito à tensão entre soberania dos Estados e promoção de direitos humanos, o fato de que nenhuma justificativa pode ser invocada para o cometimento de tal crime, pois assim determinaram o direito internacional de direitos humanos, direito internacional penal e direito internacional humanitário, guardiões dos valores comuns da humanidade. Além do que, o desaparecimento força a comunidade internacional não só a pressionar os Estados a não compactuarem com esse tipo de violência, mas também a proporem medidas para que os casos sejam investigados, os danos, reparados, e os responsáveis, punidos, tornando imperativo que se apresentem na cena internacional de maneira mais cooperativa.

Outro aspecto que aparece no debate acerca do desaparecimento, e também de graves violações de direitos humanos, é o direito à verdade, compreendido como basilar para os regimes que se pretendam democráticos - por vezes associado à transparência ou livre acesso às informações públicas. Saber os fatos relativos às circunstâncias das violações de direitos humanos consiste não só em direito das vítimas, mas de toda a sociedade, na perspectiva de que tem o potencial de disparar outros modos de se elaborar o passado, de forma a gerar no presente outros comportamentos de cidadania e relação com as instituições públicas.

Em suma, a importância de refletir acerca do crime de desaparecimento forçado, cometidos no recente passado ditatorial no contexto da América Latina, reside também na necessidade de afirmação dessas novas democracias, pois, observar esse processo de elaboração do ocorrido 
também pode ser um elemento que favorece olhar para o presente de maneira mais integral, e entender um pouco melhor a atuação e comportamentos das instituições públicas e as opções políticas feitas pelos atores sociais.

Para o tratamento desta problemática, a dissertação foi dividida em quatro capítulos, buscando abordar a construção do desaparecimento forçado de pessoas como fenômeno jurídico para o direito internacional, a interdependência de ramos do direito internacional em relação ao desaparecimento, a análise dos casos de desaparecimento julgados pela Corte Interamericana de Direitos Humanos à luz do direito à verdade, e, por fim, uma aproximação entre memória e direitos humanos.

No primeiro capítulo, intitulado "Construção histórica e normativa do crime de desaparecimento forçado de pessoas", foi sistematizado o desenvolvimento da formação normativa internacional concernente ao fenômeno do desaparecimento, desde a primeira manifestação da ONU em Resolução acerca da questão, datada de 1978, até 2009. É conferida especial atenção às atividades do grupo de trabalho da ONU, na medida em que a maioria das fontes utilizadas decorreu dos relatórios anuais desse grupo, apresentados à Comissão e ao Conselho de Direitos Humanos da ONU.

No capítulo subseqüente, "Interdependência de ramos do direito internacional público em relação ao desaparecimento forçado de pessoas", foi traçado o histórico de formação e desenvolvimento do direito internacional humanitário, direito internacional dos direitos humanos e direito internacional penal, de forma a demonstrar como eles se informam para a construção dos direitos humanos e, neste caso especificamente, para proteger as pessoas contra o desaparecimento.

Em seguida, foram analisados todos os casos de desaparecimento forçado de pessoas julgados pela Corte Interamericana de Direitos Humanos a partir do direito à verdade, no capítulo nomeado "Direito à verdade e os casos de desaparecimento da Corte Interamericana de Direitos Humanos". Foram observadas também as determinações da Corte acerca das violações da Convenção Americana, além das reparações foram estabelecidas em cada caso.

Finalmente, o último capítulo analisa a aproximação entre memória e direitos humanos, no sentido de compreender melhor a relação entre esses temas nos casos de desaparecimento 
forçado, chegando-se à conclusão de que fomentar a construção de memórias de vítimas de graves violações de direitos humanos, e considerá-las no debate público, pode favorecer uma leitura mais ampla do presente, evitando repetições daquilo que não está de acordo com os valores de direitos humanos. 


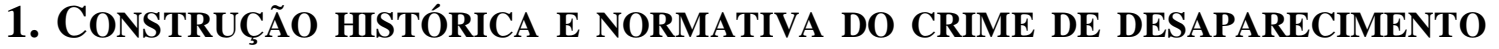 FORÇADO DE PESSOAS}

O prisioneiro desaparecido é o nome que damos aos membros das nossas famílias que foram tirados de nossas casas, sob nossos olhos, ou em seus locais de trabalho, universidades, sem testemunhas oculares ou provas de sua detenção. Quem o detém são membros dos serviços de inteligência militar. $\mathrm{O}$ desaparecido é mantido em segredo e todos nossos esforços, como habeas corpus, cartas e buscas junto aos órgãos governamentais, têm tido a seguinte resposta: esta pessoa nunca foi detida. ${ }^{4}$

Essa manifestação dos familiares de desaparecidos expressa na década de 1970 mostra com precisão o que foi esse fenômeno em seu início. É possível imaginar, para aqueles que não viveram, a atuação do aparelho repressivo em relação aos opositores do regime ditatorial, pautada na intolerância com a diferença. O desaparecimento forçado de pessoas localiza-se nesse campo de arbitrariedades de um Estado junto aos seus cidadãos, mas sobretudo onde o princípio de humanidade não impera ${ }^{5}$.

\subsection{O fenômeno do desaparecimento forçado de pessoas}

O desaparecimento de pessoas não é fenômeno recente na história da humanidade. Nos séculos passados, os corpos dos soldados mortos nas guerras não eram encontrados e, em razão disso, no século XIX, durante a guerra civil norte-americana, os soldados receberam uma placa de identificação, levada junto ao corpo, contendo nome, regimento e divisão a que faziam parte no exército, como uma estratégia para localizar os corpos em caso de morte nas batalhas. Após a Primeira Guerra Mundial, essas placas tornaram-se obrigatórias, de acordo

\footnotetext{
${ }^{4}$ The disappeared prisioners is the name we give to members of our families who have been taken from our homes, in front of our eyes, or in their work places, colleges and universitues, with eye-witnesses or strong proof of their detention. The people who detained them were members of the military intelligence services. They are being held in secret and all our efforts, such as writs of habeas corpus, letters and interviews with governamental officials, have been flung back in our faces with the following answer: this person has never been detained. Relato da Agrupación de familiares de los detenidos desaparecidos, Statement, Santiago, Chile, 1975. Apud: REOCH, Richard. "Disappearances" and the international protection of human rights. In: The year book of world affairs. Londres: Stevens \& Sons, 1982. (Todas as traduções desta dissertação foram feitas livremente pela autora).

${ }^{5}$ E/CN.4/1996/38, p. 37, para. 465. The systematic practice of acts of enforced disappearance is of the nature of a crime against humanity. In addition to the revival of systematic torture and genocide, the practice of enforced disappearances is one of the most heinous "contributions" of human beings to the twentieth century, which is often referred to as the most violent in history.
} 
com as determinações estabelecidas durante a Conferência Internacional da Cruz Vermelha ocorrida em $1925^{6}$. Esta foi uma das primeiras ações no sentido de reduzir o número de soldados desaparecidos em batalhas.

Durante a Segunda Guerra Mundial outro tipo de desaparecimento de pessoas passou a ser praticado, evidenciando que essa questão ia além dos soldados desaparecidos em campos de batalha. Dessa maneira, civis, por meio da política nazista de extermínio, foram separados de suas famílias, presos arbitrariamente e mortos. Essa tática de intimidação nazista remonta, precisamente, o decreto "Noite e Neblina"7, de 17 de dezembro de 1941, em que desaparecer com as pessoas era forma de deixar as vítimas e a população em geral sem saberem acerca do que poderia ocorrer com suas vidas ${ }^{8}$. O conteúdo desse decreto referia-se a retirar as pessoas que ameaçavam a segurança alemã dos territórios ocupados, e encaminhá-las a Alemanha para serem executadas. Toda essa ação não podia ser visível, ou seja, aos agentes envolvidos nesses desaparecimentos era proibido oferecer informações acerca do paradeiro dessas pessoas. ${ }^{9}$

Outra forma de desaparecimento de pessoas, que interessa a este trabalho, é aquele que se configurou durante as ditaduras da América Latina ${ }^{10}$. Essa denominação de desaparecimento forçado de civis difere-se daquele cometido durante o regime nazista, à medida que se pauta em motivações de repressão política e de maneira sistematizada ${ }^{11}$. Nesse sentido, o

\footnotetext{
${ }^{6}$ MARTIN, Sophie. The missing. In International Review of the Red Cross. Humanitarian debate: law, policy, action. Vol. 84, 2002, pp. 723-726. Cf. também Resolução I da 24 ${ }^{\text {a }}$ Conferência da Cruz Vermelha e do Crescente Vermelho, Manila, 1981.

7 Documento L-90 Vol. 7 das atas dos processos de Nuremberg. Para verificar a interpretação desse decreto ver Informe E/CN.4/2002/71, apresentado pelo Relator Independente Manfred Nowak, em seu exame sobre o marco internacional existente em matéria penal e de direitos humanos para a proteção das pessoas contra o desaparecimento forçado ou involuntário de pessoas, em conformidade com o para 11 da Resolução 2001/46 da Comissão de Direitos Humanos.

${ }^{8}$ PARAYRE, Sonia. La desaparición forzada de personas como violación continuada de derechos humanos y su incidência en la determinación de la competência ratione temporis de la corte interamericana de derechos humanos. In IDDH. Vol. 29, 1999, p. 26.

${ }^{9}$ Decreto Noite e Neblina, III. (...) In case German or foreign authorities inquire about such prisoners, they are to be told that they were arrested, but that the proceedings do not allow any further information.

${ }^{10} \mathrm{O}$ termo desaparecimento não era comum no vocabulário de direitos humanos até que essa prática passou a se desenvolver como política de repressão, inicialmente nos anos 1960 na Guatemala, e em seguida nos países vizinhos da América Latina. LIVERMORE, J. Daniel e RAMCHARAN, B. G. Enforced or involuntary disappearances: an evaluation of a decade of United Nations action. In Canadian Human Rights Year Book, 1989-1990, p. 218.

${ }^{11}$ ROJAS, Manuel Hinojo. Al hilo de la Declaración de 1992 de La Asamblea General de Naciones Unidas sobre aa protección de todas las personas contra lãs desapariciones forzadas. In Anuario de Derecho Internacional, Universidad de Navarra, Pamplona, 1996, p. 494.
} 
desaparecimento forçado de pessoas, expressão cunhada nesse momento histórico, constitui, de acordo com a primeira manifestação da ONU em 1978, no seguinte:

É a violação complexa de direitos fundamentais, alguns inderrogáveis, praticada por agentes públicos (geralmente os encarregados da segurança e/ou cumprimento das normas jurídicas), em que, de forma arbitrária, violenta e à margem da lei, detêm, encarceram e, não raras vezes, assassinam pessoas, não informando os fatos, o paradeiro da vítima ou a motivação da ação a quem de direito. Trata-se, desse modo, em qualquer situação ou circunstância, de um crime injustificável contra o direito à vida, à liberdade e à segurança pessoais, composto mediante tortura ou tratamento, pena ou castigo cruéis, e apartado do devido processo legal. Acima da normalidade, tem suas conseqüências extrapoladas além da vítima principal, seja em relação à angústia e à dor intermitente do cônjuge, dos filhos, dos parentes e dos amigos, que as circunstâncias do desaparecimento causam, seja na insegurança coletiva gerada por esses crimes, já que os ofensores (diretos ou indiretos) aos direitos fundamentais implicados são justamente os encarregados de garanti-los na entidade estatal. ${ }^{12}$

Diversos compromissos foram assumidos pela comunidade internacional a partir da Resolução da Assembléia Geral 33/173 de $1978^{13}$, no âmbito da ONU, inclusive com a criação do Grupo de Trabalho sobre Desaparecimento Forçado ou Involuntário de Pessoas, em 1980, para examinar as questões atinentes ao desaparecimento. Os Estados comprometeram-se a buscar os desaparecidos e apurar os fatos com imparcialidade, investigar e punir os responsáveis pelos desaparecimentos, e a cooperar com os outros Estados, com as organizações internacionais em geral, na busca efetiva pelas pessoas desaparecidas.

No ano de 1992, a Assembléia Geral da ONU aprovou a Declaração sobre a Proteção de Todas as Pessoas contra o Desaparecimento Forçado ou Involuntário. Na Declaração há o apelo à responsabilização jurídica dos agentes que promovem o desaparecimento forçado, assim como sua qualificação como crime contra a humanidade. Também se ocupa, em seu preâmbulo, em estabelecer uma limitação ao conceito de desaparecimento forçado:

Profundamente preocupado de que em muitos países, geralmente de modo persistente, ocorrem os desaparecimentos forçados, no sentido de que as pessoas são presas, detidas ou trasladadas contra sua vontade, sendo privadas de sua liberdade por agentes governamentais, de qualquer setor ou nível, ou grupos organizados que atuam em nome do governo, ou com seu apoio direto ou indireto, consentimento ou aquiescência, seguido por uma recusa em revelar a sorte ou o paradeiro dessas pessoas ou reconhecer que estão privadas de liberdade, subtraindo-as, assim, à

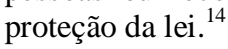

\footnotetext{
${ }^{12}$ JARDIM, Tarcisio Dal Maso. Crime do desaparecimento forçado de pessoas. Brasília: Brasília Jurídica, 1999 , pp. 33-34.

${ }^{13}$ Resolução 33/173 da Assembléia Geral da ONU, adotada na 90ª plenária da 33a . Sessão, em 20 de dezembro de 1978.

${ }^{14}$ Deeply concerned that in many countries, often in a persistent manner, enforced disappearances occur, in the sense that persons are arrested, detained or abducted against their will or otherwise deprived of their liberty by
} 
O Estatuto de Roma adotado em 17 de julho de 1998, ao criar o TPI e definir os crimes de sua competência, incluiu o desaparecimento forçado de pessoas como crime contra a humanidade, e conceituou-o da seguinte forma, em seu art. 7,2, i:

Por desaparecimento forçado de pessoas entende-se a prisão, detenção ou seqüestro de pessoas por um Estado ou por uma organização política, ou com a autorização, apoio ou aquiescência destes, seguidos da negativa de informar sobre a privação de liberdade ou dar informação sobre a sorte ou paradeiro dessas pessoas, com a intenção de deixá-las fora da lei por um período prolongado. ${ }^{15}$

A Convenção Internacional para Proteção de Todas as Pessoas contra o Desaparecimento Forçado, adotada em 2006 pela ONU, determina em seu art. 2 que "desaparecimento forçado é considerado a prisão, detenção, seqüestro ou qualquer outra forma de privação de liberdade por agentes do Estado ou por pessoas ou grupos agindo com sua autorização, apoio ou aquiescência, seguido por uma recusa em reconhecer a privação de liberdade ou ocultação do destino ou paradeiro da pessoa desaparecida, que deixam a pessoa à margem da proteção da lei." 16

Essas denominações foram tratadas no âmbito do sistema global de proteção dos direitos humanos. Contudo, é fundamental observar os trabalhos da OEA, que, em 1994, adotou a Convenção Interamericana sobre o Desaparecimento Forçado de Pessoas, e, por meio da Comissão e da Corte de Direitos Humanos, vem acompanhando diversos casos de desaparecimento, em decorrência das ditaduras vividas pelos Estados latino-americanos no século XX, e formando uma gama de jurisprudência acerca do assunto, sempre condenando os Estados a repararem os familiares dos desaparecidos, empreenderem esforços para localizar a pessoa, e demandando a punição dos responsáveis pela violação. Desse modo, o

officials of different branches or levels of Government, or by organized groups or private individuals acting on behalf of, or with the support, direct or indirect, consent or acquiescence of the Government, followed by a refusal to disclose the fate or whereabouts of the persons concerned or a refusal to acknowledge the deprivation of their liberty, which places such persons outside the protection of the law. A/RES/47/133, adotada em 18 de dezembro de 1992, na 92a . Plenária.

15 Enforced disappearance of persons" means the arrest, detention or abduction of persons by, or with the authorization, support or acquiescence of, a State or a political organization, followed by a refusal to acknowledge that deprivation of freedom or to give information on the fate or whereabouts of those persons, with the intention of removing them from the protection of the law for a prolonged period of time. A/CONF.183/9, adotada em 15 a 17 de julho de 1998.

${ }^{16}$ For the purposes of this Convention, "enforced disappearance" is considered to be the arrest, detention, abduction or any other form of deprivation of liberty by agents of the State or by persons or groups of persons acting with the authorization, support or acquiescence of the State, followed by a refusal to acknowledge the deprivation of liberty or by concealment of the fate or whereabouts of the disappeared person, which place such a person outside the protection of the law. A/RES/61/177, adotada em 20 de dezembro de 2006, na 61ª . Sessão. 
posicionamento do Direito Internacional vigente é no sentido de impor aos Estados onde ocorreu o desaparecimento forçado de pessoas, o dever de investigar os fatos e apurar a verdade sobre as circunstâncias dos desaparecidos, reparar a violação cometida, identificar os responsáveis e punir os culpados. ${ }^{17}$

O desaparecimento de pessoas tem seus desdobramentos no que diz respeito à violação de direitos civis, políticos, econômicos, sociais e culturais, da própria vítima do desaparecimento, mas também de sua família ${ }^{18}$. Em relação à pessoa desaparecida, considerase que seus direitos violados são o direito à liberdade e à segurança pessoal ${ }^{19}$, direito de não ser preso arbitrariamente ${ }^{20}$, direito a um julgamento justo ${ }^{21}$, direito de ser reconhecido como pessoa perante a lei $^{22}$, direito a condições mínimas de tratamento na prisão e de não ser submetido à tortura e outros tratamentos cruéis e degradantes ${ }^{23}$, direito à vida ${ }^{24}, \mathrm{e}, \mathrm{em}$ caso de mulheres grávidas desaparecidas, são negados direitos da mulher e da criança ${ }^{25}$. Esses direitos podem ser considerados como o cerne dos direitos violados da pessoa desaparecida, contudo, muitos outros também o são, como o direito à vida familiar ${ }^{26}$, e outros de natureza econômica, social ou cultural, de integridade psíquica da família do desaparecido ${ }^{27}$. Ademais, os familiares das vítimas têm o direito de saber o que aconteceu, conforme o Protocolo Adicional I das Convenções de Genebra ${ }^{28}$. É possível apontar que praticamente todos os direitos humanos básicos elencados na DUDH são violados quando ocorre o desaparecimento forçado

${ }^{17}$ COMPARATO, Fábio Konder. Que fizeste de teu irmão? In: TELES, Janaína (org.). Mortos e Desaparecidos Políticos: Reparação ou Impunidade? São Paulo: Humanitas, 2001, 2a ed., pp. 65-67.

${ }^{18}$ E/CN.4/1492, p. 65, para. 165. Ver também: KLEINMAN, Howard. Disappearances in Latin America: a human rights perspective. In Journal of international law and politics. Nova Iorque, 1987, pp. 1042-1045.

${ }^{19}$ Cf. DUDH, art. 5, Pacto de Direitos Civis e Políticos, art. 9, Convenção Americana, art. 7, Convenção Européia DH, art. 5.

${ }^{20}$ Cf. DUDH, art. 9, Pacto de Direitos Civis e Políticos, art. 9, Convenção Americana, art. 7, Convenção Européia DH, art. 5.

${ }^{21}$ Cf. DUDH, arts. 10 e 11, Pacto de Direitos Civis e Políticos, art. 14, Convenção Americana, art. 8, Convenção Européia DH, art. 6.

${ }^{22}$ Cf. DUDH, art. 6, Pacto de Direitos Civis e Políticos, art. 16, Convenção Americana, art. 3.

${ }^{23}$ Cf. DUDH, art. 5, Pacto de Direitos Civis e Políticos, art. 7 e 10, Convenção Americana, art. 5, Convenção Européia DH, art. 5. Ver também Resolução 663 (XXIV) do Conselho Econômico e Social acerca das Regras Mínimas para tratamento de prisioneiros, de 31 de julho de 1957, especialmente Regras 4 (aplicável a todas as categorias de prisioneiros), 7 (exigência de registros de cada preso), 37 (assegura a comunicação do preso com sua família), 44 (determina que a instituição prisional informe à família em caso de morte, doença ou transferência do preso) e 92 (garante ao preso que ainda não foi julgado a comunicar sua família da detenção).

${ }^{24}$ Cf. DUDH, art. 3, Pacto de Direitos Civis e Políticos, art. 6, Convenção Americana, art. 4, Convenção Européia DH, art. 2.

${ }^{25}$ Cf. DUDH, art.25, Pacto de Direitos Civis e Políticos, art. 24, Pacto de Direitos Econômicos, Sociais e Culturais, art. 10, Convenção Americana, art. 19.

${ }^{26}$ Cf. DUDH, art. 12 e 16., Pacto de Direitos Civis e Políticos, arts. 17 e 23, Convenção Americana, art. 4, Convenção Européia DH, art. 2.

${ }^{27}$ E/CN.4/1492, p. 67, para. 168.

${ }^{28}$ E/CN.4/1492, p. 67, para. 168. 
de uma pessoa. Ademais, diversos direitos das crianças e das mulheres grávidas consagrados como objeto de proteção em instrumentos internacionais ${ }^{29}$ são violados com o desaparecimento de um familiar, ou por vezes das próprias crianças. Há também uma série de direitos advindos da relação familiar que não são providos, como ser registrado após o nascimento $^{30}$, a obrigatoriedade de identificação das crianças separadas de seus pais em casos de conflitos armados ${ }^{31}$.

Entidades não-governamentais, em um esforço de analisar os tipos de sofrimentos causados em decorrência do desaparecimento forçado à vítima, e os impactos causados aos seus familiares, elaboraram um relatório durante o $2^{\circ}$. Congresso Latino-Americano dos Familiares das Pessoas Desaparecidas, em Caracas, em novembro de 1982. Quanto à pessoa desaparecida, os danos psicológicos dependem do modo como ela é detida, a que condições é submetida, e varia de acordo com sua faculdade crítica, seu nível de medo, sua convicção ideológica, e sua habilidade de não se sentir sozinho. Os efeitos para os familiares, segundo o mesmo diagnóstico, estão ligados a uma sensação de sofrimento e angústia prolongados e sem momento para terminar, já que esperam por seu ente querido sem cessar. São diversos estágios por que passam os familiares; o primeiro é de impotência e inatividade, decorrente do medo de represálias, e do receio de que suas ações no sentido de buscarem pelo desaparecido possam conduzi-lo à morte. O segundo é a busca individual do familiar, e o terceiro a associação a outros familiares que passam pela mesma situação, empreendendo ações coletivas para localizarem o desaparecido. As conseqüências do próprio desaparecimento e das buscas frustradas levam os familiares a culparem-se pelo fato, ocasionando uma ruptura na unidade familiar e uma paralisia frente ao convívio social. ${ }^{32}$

Dessa maneira, uma forma de se nomear o estado psicológico dos familiares e o grande prejuízo por eles sofridos é sustained shock, que é um prolongado e latente estado crítico que ficam, marcado por angústia e incerteza, caracterizado por uma busca inconclusiva do seu

\footnotetext{
${ }^{29}$ Cf. DUDH, art. 25, Pacto de Direitos Civis e Políticos, art. 24, Pacto de Direitos Econômicos, Sociais e Culturais, art. 10, Convenção sobre o Direito das Crianças, Convenção Americana, art. 19, Convenção de Genebra de 1949 sobre a proteção de civis em tempos de guerra, arts. 14, 17, 24, 38, quanto à mulher grávida, há violação da Convenção Americana, art. 4, do Pacto de Direitos Civis e Políticos, art. 6, e do Protocolo Adicional I art. 76, e Protocolo Adicional II art. 6 das Convenções de Genebra de 1949.

${ }^{30}$ Cf. Pacto de Direitos Civis e Políticos, art. 24, para $2^{\circ}$. A Convenção Americana, no art. 18 estabelece o direito que tem a criança de ser registrada com o sobrenome dos seus pais.

${ }^{31}$ Convenção de Genebra de 1949 sobre a proteção de civis em tempos de guerra, art. 50. E, se em caso de conflito esses direitos são garantidos, em tempo de paz, por óbvio, eles devem ser resguardados.

${ }^{32}$ E/CN.4/1983/14, pp. 47-8, paras. 135-6.
} 
ente querido. As crianças também ficam muito abaladas com o desaparecimento, pois participam diretamente do desgaste familiar, assinalado pelo medo, injustiça e silenciamento. Além disso, outras implicações do desaparecimento como diminuição dos recursos econômicos, estresses psicológicos que podem decorrer em outros problemas de saúde, mudanças da rotina, em virtude de boa parte do tempo ser dedicada a localizar os familiares desaparecidos, instabilidade jurídica e social. ${ }^{33}$

Do ponto de vista da criança, familiar do desaparecido, seu estado psicológico pode ser expresso pelos sentimentos de abandono e falta de proteção, especialmente porque todo o foco da sua família volta-se para a tentativa de encontrar a vítima. Essa síndrome de abandono somatizada na saúde física da criança, mostra a confusão que a acomete, marginalizando-a, tanto dentro da própria família, da sociedade, quando aquela a impõe ao isolamento visando a sua proteção, ou em caso das imposições das ações oficiais e das reações públicas e sociais que passam a rejeitar a criança. Outro ponto importante é o estresse ocasionado à criança quando seu familiar é preso em sua presença, pois desperta nela o sentimento de medo e impotência diante da violência, e como toda a família está tomada pelas mesmas angústias, fica incapaz de dar assistência a ela. ${ }^{34}$

Dessa maneira, cumpre reafirmar a atualidade e importância desse tema, pois, além de a maioria dos casos de desaparecimento forçado não ter sido solucionada, seus perpetradores não terem sido punidos, e as circunstâncias acerca dos fatos permanecerem em suspenso na vida de milhares de familiares da pessoa desaparecida, esse fenômeno constitui uma das mais graves violações de direitos humanos.

\subsection{Histórico da normativa internacional para proteção contra o desaparecimento forçado de pessoas no Direito Internacional}

A prática sistemática de desaparecimento forçado de pessoas teve início na década de 1960 , na Guatemala, em que agentes de segurança fora de expediente, formando esquadrões da morte, passaram a perseguir guerrilheiros opositores ao governo. Mesmo após o fim das guerrilhas, no fim dessa década, os esquadrões da morte continuaram a operar, abduzindo e

${ }^{33} \mathrm{E} / \mathrm{CN} .4 / 1984 / 21$, p. 51, para. 147.

${ }^{34}$ E/CN.4/1984/21, pp. 51 e 52, paras. 148-150. 
assassinando aqueles contrários ao governo e seus simpatizantes ${ }^{35}$. Em seguida, no começo da década de 1970, esse fenômeno passou a ser exercido em países da América Latina, especialmente no Chile e Brasil, e em outros da África, Ásia e Oriente Médio. Dessa forma, o termo desaparecido surgiu no Chile e Argentina, para designar o desaparecimento de pessoas em situações diversas, quando familiares, amigos, e advogados tinham razão para acreditar que essas pessoas haviam sido apreendidas por agentes do governo, ou seqüestrados sob seus auspícios. $^{36}$

A Assembléia Geral da ONU voltou efetivamente sua atenção para a temática em relevo muito em virtude dos desaparecimentos ocorridos no Chipre ${ }^{37}$, face à adoção da Resolução 32/128 de 1977, e pela situação no Chile, trazida para o seio da organização a partir das recomendações do Relator Independente acerca da questão das pessoas desaparecidas ${ }^{38}$. Em 15 de dezembro de 1980, a Assembléia aprovou a Resolução 35/I88, intitulada Proteção dos Direitos Humanos no Chile, expressando sua preocupação com o fenômeno do desaparecimento, determinando que as autoridades desse país investigassem e localizassem o paradeiro desses desaparecidos, anunciando inclusive a necessidade de instaurar procedimentos penais contra os responsáveis ${ }^{39}$.

\subsubsection{Resolução $33 / 137$}

O marco que reflete a preocupação da comunidade internacional acerca da questão do desaparecimento forçado de pessoas é a Resolução 33/173 adotada pela Assembléia Geral da ONU em 20 de dezembro de 1978, em sua 33ª Sessão. A Resolução tem como tema o desaparecimento de pessoas e aponta a clara violação aos artigos 3, 4, 5, 9 e 11 da DUDH, ou seja, o direito à vida, à liberdade e segurança, a não ser submetido a torturas, a não ser arbitrariamente preso e a não ter um julgamento justo e legal ${ }^{40}$.

\footnotetext{
${ }^{35}$ REOCH, Richard. "Disappearances" and the international protection of human rights. In: The year book of world affairs. Londres: Stevens \& Sons, 1982, p. 166-7.

${ }^{36}$ Idem, pp. 168-9

${ }_{38}^{37}$ E/CN.4/1435, p. 6, para. 20.

${ }^{38}$ Cf. Resolução Assembléia Geral 34/179; Relatório A/34/583/Add.1.

${ }^{39}$ E/CN.4/1435, p. 7, para. 21.

${ }^{40}$ DUDH; Resolução 33/173.
} 
Nessa Resolução a Assembléia Geral da ONU expressou sua preocupação com a quantidade de casos de desaparecimento relatados de várias partes do mundo, como resultado do excesso e arbitrariedades cometidas pelos agentes estatais responsáveis pela segurança e órgãos correlatos, além da dificuldade de obter informações a respeito desses casos, causando angústia e sofrimento aos familiares dos desaparecidos ${ }^{41}$. Recomendou aos governos que despendessem recursos para localizar os desaparecidos e o fizessem mediante investigações imparciais; que os sistemas de justiça e segurança dos Estados fossem fiscalizados em relação à sua atuação, que deveria estar de acordo com a lei, e, em caso de arbitrariedades, que os agentes fossem responsabilizados; que assegurassem o respeito aos direitos humanos de todas as pessoas, especialmente em caso de prisão e detenção; e que colaborassem com outros países, com a ONU, suas agências especializadas, e órgãos humanitários, para a localização das pessoas desaparecidas ${ }^{42}$.

Em outubro de 1979 a Assembléia Geral da Comissão de Direitos Humanos da OEA adotou, na sua 9 ${ }^{a}$. sessão regular ocorrida em La Paz, a Resolução intitulada Relatório Anual da Comissão Interamericana de Direitos Humanos, que apontou o desaparecimento forçado como instituto intolerável para o hemisfério sul, contrário aos valores construídos em âmbito da organização ${ }^{43}$. Na sessão seguinte, em 27 de novembro de 1980, em sua décima sessão regular, a Assembléia Geral da OEA apontou a necessidade premente de colocar fim a esse tipo de violação de direitos humanos, e a importância de empreender esforços para localizar as pessoas desaparecidas. Ademais, recomendou aos governos que fizessem um levantamento de todas as pessoas desaparecidas para que todos soubessem das detenções, e que elas fossem realizadas apenas por agentes autorizados e sob os auspícios da lei ${ }^{44}$.

A Anistia Internacional, na $36^{\circ}$. sessão da Comissão de Direitos Humanos ocorrida em 22 de fevereiro de 1980, elencou dois elementos essenciais que caracterizam o desaparecimento de pessoas. O primeiro é que a detenção ou seqüestro da pessoa não é cometido por terroristas ou criminosos comuns, mas por agentes do governo, ou grupos diretamente envolvidos com ele. O segundo diz respeito à negação, por parte do governo, da detenção; ele alega que não sabe do paradeiro da pessoa desaparecida, que ela não está sob sua jurisdição. Essa violação de

\footnotetext{
${ }^{41}$ Resolução 33/173.

${ }^{42}$ Resolução 33/173; E/CN.4/1435, p. 09, para. 14

43 Neste mesmo ano, o Conselho de Ministros do Comitê da Europa, por meio da Recomendação n. R(79)6, também expressou sua preocupação em localizar as pessoas desaparecidas.

${ }^{44}$ E/CN.4/1435, p. 13, para. 24.
} 
direitos humanos difere-se da prisão arbitrária, por exemplo, porque neste caso o governo ao menos admite que a pessoa está sob sua custódia ${ }^{45}$. Em razão dessa negação do governo, a pessoa fica completamente sem nenhuma proteção jurídica nacional ou internacional, porque todos os instrumentos presumem saber ao menos onde a pessoa se encontra.

Essa negação do governo pode acontecer de diversas formas, pode ser explícito, por meio de uma declaração formal, ou implícito, pela omissão em relação à apreensão. Essa situação pode acontecer quando o sistema de detenção já não respeita as garantias em relação a todos os presos, e por conseguinte o devido processo legal está prejudicado. Outra forma dessa omissão ocorrer se dá quando a apreensão é feita por agentes desconhecidos, por grupos não oficiais, e as autoridades governamentais negam-se a investigar o caso. Essa negação pode ser interpretada como a participação do governo na detenção, e sua conseqüente tentativa de se exonerar do seu papel no caso de desaparecimento. Há também instâncias em que o governo admite a prisão, e anuncia que a pessoa foi solta, embora ela nunca apareça. ${ }^{46}$

Na Conferência sobre o Direito das Mulheres ocorrida em Copenhagen, entre 14 e 30 de julho de 1980, a questão do desaparecimento forçado apareceu, pois mulheres e seus filhos também são vítimas diretas desse crime, além de indiretas. A recomendação da Conferência foi no sentido de que a Assembléia Geral propusesse aos governos que empreendessem esforços para erradicar esse tipo de violação de direitos humanos, e que assistissem as mulheres e os filhos das vítimas de desaparecimento forçado ${ }^{47}$.

No sexto Congresso das Nações Unidas sobre a prevenção do crime e o tratamento dos criminosos, que aconteceu em Caracas, de 25 de agosto a 05 de setembro de 1980, foi adotada a Resolução sobre "Execuções extralegais", registrando que o desaparecimento forçado de pessoas é relacionado com o assassinato cometido pelo governo ou com sua anuência, determinando que os governos tomassem as medidas necessárias para prevenir esses atos. Foi também citada a medida determinada pela Assembléia Geral na Resolução 34/178 de 1979 da importância dos remédios constitucionais, como o habeas corpus, para proteger as pessoas de prisão arbitrária e não amparada em lei, por motivos políticos ou religiosos, e revelar os fatos

\footnotetext{
${ }^{45}$ REOCH, Richard. "Disappearances" and the internationals protection of human rights. In KEETON, George e SCHWARZENBERGER Georg (Editores), The year book of world affairs, 1982. Londres: Stevens e Sons, 1982. pp. 166-181.

${ }^{46}$ Idem, p. 169.

${ }^{47}$ Res. 33/173; E/CN.4/1435, p. 12, para. 22.
} 
e circunstâncias aos familiares dos desaparecidos. Nesta Resolução a Assembléia Geral determinou que todos os Estados efetivassem o direito de habeas corpus a todos os cidadãos de seu território ${ }^{48}$.

Em novembro de 1981, durante a Conferência Internacional da Cruz Vermelha, com a participação de 83 governos, do Comitê Internacional da Cruz Vermelha e da Liga das Sociedades da Cruz Vermelha, foi adotada a Resolução sobre o Desaparecimento Forçado ou Involuntário, apontando a situação alarmante do fenômeno que acontece com o consentimento dos governos, e sua consequiência em relação ao sofrimento causado às vítimas e às famílias. Nessa Conferência frisou-se o direito das famílias de saberem o lugar em que o desaparecido está preso, bem como suas condições de saúde. Além disso, foi reforçada a importância das atividades do Grupo de Trabalho sobre Desaparecimento Forçado ou Involuntário de Pessoas da ONU, das organizações não-governamentais com foco em acabar com esse tipo de violação, e encorajado aos governos a condenarem tais práticas e empreenderem esforços para a localização das pessoas desaparecidas. $\mathrm{Na} 24^{\mathrm{a}}$. Conferência Internacional da Cruz Vermelha e do Crescente Vermelho, em 1981, a Resolução II dita que o Comitê Internacional da Cruz Vermelha e qualquer organização humanitária é responsável por garantir todas as facilidades para se descobrir o destino das pessoas desaparecidas. Na Conferência seguinte, em 1986, determina-se, pela Resolução XIII, a obrigatoriedade de as partes beligerantes fornecerem cartões de identificação para suas forças armadas e instalarem centros de informações durante os conflitos. $^{49}$

A Comissão Interamericana de Direitos Humanos, em seu Relatório Anual de 1980 para a Assembléia Geral da OEA, assinalou a natureza cruel e desumana da prática do desaparecimento forçado de pessoas em relação à vítima, logo após sua detenção, em termos de danos à integridade física e psicológica, além, obviamente, dos danos causados aos familiares do desaparecido. Apontou também uma aparente diminuição dos casos de desaparecimento, mas que o fenômeno não estaria resolvido até que fosse feito um relatório completo acerca da situação de todos os casos reportados. Todavia, alertou para o fato de que a estrutura dos governos permitia esse tipo de prática, e enquanto as instituições continuassem a negar os fatos e o paradeiro das vítimas seria improvável a resolução dos casos. Dessa maneira, recomendou à Assembléia Geral que forçasse os Estados, onde tivesse havido tal

\footnotetext{
${ }^{48}$ E/CN.4/1435, pp. $12-3$, para. 23.

${ }^{49}$ E/CN.4/1492, p. 7, para. 21.
} 
violação, a localizarem as pessoas desaparecidas, e a criar um registro centralizado com o nome de todas as pessoas presas e locais de sua detenção ${ }^{50}$.

Em 1987, pela primeira vez, uma corte internacional apreciava três casos de desaparecimento forçado de pessoas. A Corte Interamericana de Direitos Humanos julgaria casos hondurenhos, e havia grande expectativa quanto a esses julgamentos, pois a Corte deveria se pronunciar acerca de várias questões adicionais ao fenômeno de desaparecimento, o que daria mais substância aos órgãos da ONU para a compreensão da questão ${ }^{51}$. Com o primeiro julgamento dessa jurisdição internacional, em $1989^{52}$, estabeleceu-se um precedente quanto à investigação e ajuizamento de um caso de desaparecimento forçado de pessoas, pois a sentença declarou que o desaparecimento forçado constitui crime contra a humanidade e violação múltipla e continuada de inúmeros direitos humanos, e por isso as sanções jurídicas não podiam estar restritas às limitações aplicadas a outros delitos quanto ao marco cronológico ${ }^{53}$.

\subsubsection{Declaração sobre a Proteção de Todas as Pessoas contra o Desaparecimento Forçado}

O projeto da Declaração sobre a Proteção de todas as Pessoas do Desaparecimento Forçado ou Involuntário nasceu de um pedido da Comissão de Direitos Humanos a Subcomissão de Prevenção de Discriminações e Proteção de Minorias, para que elaborasse uma declaração contra a prisão arbitrária e, em 1988, o presidente do grupo de trabalho sobre detenção e o relator independente Louis Joinet apresentaram o projeto elaborado por representantes de organizações não-governamentais, a Anistia Internacional, o Comitê de Advogados pelos Direitos Humanos e a Comissão Internacional de Juristas. ${ }^{54}$

O projeto foi submetido à apreciação do Grupo de Trabalho sobre Desaparecimento Forçado ou Involuntário pela Subcomissão de Prevenção de Discriminações e Proteção de Minorias

\footnotetext{
${ }^{50}$ E/CN.4/1492, p. 7, para. 22.

${ }^{51}$ E/CN.4/1988/19, p. 71, para. 248.

${ }^{52} \mathrm{O}$ primeiro caso julgado pela Corte Interamericana foi o Velasquéz Rodrigues $v s$. Honduras, que se tratava de desaparecimento forçado. Todos os casos de desaparecimento apreciados por esta Corte serão analisados no capítulo 3 desta dissertação, com vistas ao tratamento do direito à verdade.

${ }_{53}$ E/CN.4/1989/18, pp. 8-10, paras. 26 a 33.

54 BRODY, Reed e GONZALEZ, Felipe. Nunca más: an analyses of international instruments on “disappearances”. In: Human Rights Quaterly, vol. 19, n. 12, The Johns Hopkins University Press, 1997, p. 372.
} 
por sua Resolução 1988/17, e também a comentários das organizações não-governamentais com as quais o segundo grupo de trabalho vinha realizando suas atividades de maneira cooperativa $^{55}$. Considerou que o projeto era grande iniciativa no sentido da construção de uma definição jurídico-normativa ao fenômeno do desaparecimento, e, com o intuito de incorporar sugestões das organizações alinhadas a sua experiência, propôs apresentar suas observações na 41 ${ }^{\text {a }}$ Sessão da Subcomissão. Ademais, ressaltou a importância da contribuição do projeto de convenção formulada pela Comissão de Direitos Humanos da OEA, considerando que deveria seguir planejando o desenvolvimento de uma convenção internacional em âmbito global. $^{56}$

Quanto às considerações do grupo de trabalho sobre desaparecimento forçado ou involuntário de pessoas relativas ao projeto, manifestou a importância de que os trabalhos da ONU e da OEA concernentes a essa temática se desenvolvessem paralelamente, sobretudo porque esta segunda organização vinha construindo uma base consistente do desaparecimento como fenômeno jurídico internacional. Além disso, ressaltou que o impacto para a erradicação do desaparecimento com um instrumento próprio ao fenômeno seria direto, pois com a adoção do instrumento não seria mais necessário recorrer às outras normas de direito internacional para definir esse crime, que, apesar de tangenciarem a definição do desaparecimento, não especificam em si estratégias concretas para clarificar os casos de desaparecimento, bem como para prevenir que futuros acontecessem. ${ }^{57}$

\footnotetext{
${ }^{55}$ E/CN.4/Sub.2/1988/28, anexo; E/CN.4/Sub.2/1989/29/Rev.1.; E/CN.4/Sub.2/1990/WG.1/Add.1.

${ }^{56}$ E/CN.4/1989/18, pp. 8 e 86 , paras. 4 e 25 e 311.

57 E/CN.4/1990/13, pp. 7-10, paras. 29-38. Manifestação do grupo de trabalho: "The Working Group wishes to point to ongoing efforts outside the United Nations towards international standard-setting in this area, notably by the Organization of American States. The General Assembly of that organization has recently submitted to OAS member States for comments a preliminary draft of an Inter-American Convention on forced disappearance of persons. The Sub-Commission might wish to study this draft, prepared by the Inter-American Commission on Human Rights, as it contains many elements that are relevant to the consideration of the draft declaration. More generally, it would seem appropriate if the OAS and the United Nations exercises on this score would develop in a parallel manner and the two instruments be fully consistent.

"The Working Group has noted that at the present stage the Sub-Commission's draft does not contain a definition of the term of 'enforced or involuntary disappearance'. Indeed, it would not seem necessary to include a fully-fledged definition, given the fact that a declaration does not warrant one to the same extent as a convention, in which the obligations of States parties need to be accurately delineated. Nevertheless, in the Working Group's view, the normative content of the declaration may be strengthened considerably if the main elements of what constitutes a disappearance, would be reflected in the preamble to the declaration. Based on its own description of a typical example of disappearance, as presented to the Commission in 1988 (E/CN.4/1988/19, paragraph. 17), the Working Group suggests the following language:

"Deeply concerned that in many countries persons are detained or abducted against their will, for whatever reason, by officials of any branch or level of government or by organized groups or private individuals acting on behalf of or in connivance with the government, followed by a refusal to disclose the fate or whereabouts of the persons concerned or a refusal to acknowledge their arrest or detention, and that as a result such persons are placed outside the protective precinct of the law." Idem, p. 8, para. 31.
} 
A Subcomissão de Prevenção de Discriminações e Proteção de Minorias em sua 42a . Sessão aprovou o texto do projeto de Declaração sobre a proteção de todas as pessoas contra o desaparecimento forçado ou involuntário ${ }^{58}$. A resolução 29/1992 da Comissão de Direitos Humanos também aprovou o projeto, e decidiu submeter à Assembléia Geral por meio do Conselho Econômico e Social, compreendendo que a Declaração teria o potencial de guiar as ações dos Estados-Membros da ONU e da comunidade internacional, no sentido de erradicar a prática do desaparecimento forçado, que viola os princípios básicos de qualquer sociedade no mundo. ${ }^{59}$

A Declaração em tela, fruto da preocupação da comunidade internacional com a questão do desaparecimento forçado de pessoas por mais de uma década, foi adotada pela Assembléia Geral em 18 de dezembro de 1992, em sua Resolução 47/133. Invoca, em seu preâmbulo, todos os documentos internacionais de proteção de direitos humanos ${ }^{60}$ relacionados à prática do desaparecimento forçado de pessoas, e salienta que, apesar desses documentos contribuírem para a classificação do desaparecimento como uma grave violação de direitos humanos, seria essencial instituir um instrumento próprio, que propõe medidas efetivas para prevenir e erradicar tal conduta.

Está reunida na Declaração aquilo que a ONU compreende por desaparecimento forçado de pessoas como afronta à dignidade da pessoa humana, às normas de direito internacional concernentes à proteção dos direitos humanos ${ }^{61}$, conseqüentemente normas de ius cogens, com efeito erga omnes $^{62}$. Elenca diretrizes para os Estados prevenirem e erradicarem a prática

${ }^{58}$ E/CN.4/1991/20, p. 7, paras. 27-29.

${ }^{59}$ E/CN.4/1993/25, p. 15 , para. 56.

${ }^{60}$ Carta das Nações Unidas, Resolução da Assembléia Geral 33/173, Convenções de Genebra e Protocolos Adicionais, Declaração Universal de Direitos Humanos, Pacto de Direitos Civis e Políticos, Convenção contra a Tortura e Outros Tratamentos ou Penas Cruéis, Desumanos ou Degradantes, Código de conduta para os funcionários responsáveis pela aplicação da lei, Princípios fundamentais sobre a utilização da força e de armas de fogo pelos funcionários encarregados de fazer cumprir a lei, Declaração sobre os princípios fundamentais de justiça para as vítimas de delitos e de abuso de poder, Regras mínimas para o tratamento de prisioneiros, Conjunto de princípios para a proteção de todas as pessoas submetidas a qualquer forma de detenção ou prisão, Princípios relativos a uma eficaz prevenção e investigação das execuções extralegais, arbitrárias ou sumárias Resolução da Assembléia Geral 44/162.

${ }^{61}$ Declaração sobre a Proteção de Todas as Pessoas contra o Desaparecimento Forçado, art. 1.

${ }^{62}$ Cf. PERRONE-MOISÉS, Cláudia. Imunidades de chefes de Estado e crimes internacionais. Tese de Livre Docência apresentada na Faculdade de Direito da USP, 2009, pp. 11-6. Este núcleo duro da Declaração seria formado pelo direito à vida, à liberdade e segurança pessoal, direito de não ser submetido à tortura, a penas cruéis e degradantes e ao reconhecimento da personalidade jurídica. Dessa maneira, o desaparecimento forçado de pessoas constitui-se em si mesmo como delito autônomo de outras violações de direitos humanos. ROJAS, ROJAS, Manuel Hinojo. Al hilo de la Declaración de 1992 de La Asamblea General de Naciones Unidas sobre 
do desaparecimento, vedando sua autorização ou promoção, e propondo sua cooperação com todos os interessados em coibir tal prática ${ }^{63}$. Destaque-se especialmente para a determinação de os Estados tipificarem em suas legislações nacionais penais o desaparecimento como crime, passível de sanção penal, somada à responsabilidade civil do agente ${ }^{64}$. Expressa também que ninguém poderá se furtar da responsabilidade sob a alegação de cumprimento de ordens, assim como nenhum motivo político será razão para o cometimento do desaparecimento ${ }^{65}$.

Seqüencialmente, a Declaração determina que o acesso ao paradeiro da vítima deve ser garantido aos familiares, de modo que todas as instituições públicas e prisionais devem ser legítimas, e as condições de detenção previstas em lei, assim como as garantias processuais obedecidas $^{66}$. Ademais, salienta que somente as jurisdições comuns têm competência para julgar os agentes responsáveis pelo cometimento do desaparecimento forçado, excluindo-se assim a militar ${ }^{67}$. Determina, finalmente, que o desaparecimento é delito continuado até que os fatos sejam esclarecidos e o paradeiro da vítima conhecido ${ }^{68}$.

A Declaração foi referendada durante a Conferência de Viena, em que participaram representantes de 171 Estados, evidenciando a cristalização dos princípios desenvolvidos ao longo dos anos de atuação da ONU acerca da temática do desaparecimento forçado de pessoas $^{69}$. A validade jurídica deste instrumento para o direito internacional é incontestável, na medida em que foi adotada mediante consenso dos Estados, além de desenvolver e especificar aquilo já preconizado na Carta das Nações Unidas, e, por ser objeto de proteção de direitos humanos, constituir-se princípio geral de direito internacional ${ }^{70}$.

la protección de todas las personas contra lãs desapariciones forzadas. In Anuario de Derecho Internacional, Universidad de Navarra, Pamplona, 1996, pp. 499 a 501.

${ }^{63}$ Declaração sobre a Proteção de Todas as Pessoas contra o Desaparecimento Forçado, arts. 2 e 3.

${ }^{64}$ Idem, arts. 4 e 5.

${ }^{65}$ Idem, arts. 6 a 10.

${ }^{66}$ Idem, arts. 9 a 13 .

${ }^{67}$ Idem, art. 16.

${ }^{68}$ Idem, art. 17.

69 Cf. A/CONF.157/24 (Part I), p. 43, para. 62: The World Conference on Human Rights, welcoming the adoption by the General Assembly of the Declaration on the Protection of All Persons from Enforced Disappearance, calls upon all States to take effective legislative, administrative, judicial or other measures to prevent, terminate and punish acts of enforced disappearances. The World Conference on Human Rights reaffirms that it is the duty of all States, under any circumstances, to make investigations whenever there is reason to believe that an enforced disappearance has taken place on a territory under their jurisdiction and, if allegations are confirmed, to prosecute its perpetrators.

${ }^{70}$ ROJAS, ROJAS, Manuel Hinojo. Al hilo de la Declaración de 1992 de La Asamblea General de Naciones Unidas sobre la protección de todas las personas contra lãs desapariciones forzadas. In Anuario de Derecho 


\subsubsection{Convenção Interamericana sobre Desaparecimento Forçado de Pessoas}

Em 1987 a Assembléia Geral da OEA solicitou à Comissão Interamericana de Direitos Humanos que preparasse um primeiro projeto de Convenção sobre desaparecimento forçado de pessoas, que, em concerto com organizações não-governamentais, apresentou-a no ano seguinte. Foi estabelecido um grupo de trabalho pelo Comitê do Conselho Permanente sobre Negócios Jurídicos e Políticos da OEA e durante anos apreciou o projeto quando, em 1992, apresentou uma versão bastante criticada por países como Argentina, Chile e Canadá, e organizações não-governamentais, em razão de as propostas não proverem efetiva proteção das pessoas contra desaparecimento forçado, além de aceitar a obediência devida como justificativa para escusa de responsabilidade criminal. Daí em diante, o Conselho passou a incorporar no projeto as questões das organizações, inspirado pelas previsões mais progressistas da Declaração de 1992 da ONU. ${ }^{71}$

A Resolução da Assembléia Geral da OEA 1256(XXIV-0/94), de 9 de junho de 1994 adotou, em Belém do Pará, Brasil, a Convenção Interamericana sobre Desaparecimento Forçado de Pessoas, após projeto elaborado pela Comissão de Direitos Humanos, e apreciado pela Assembléia Geral da $\mathrm{OEA}^{72}$. A Convenção entrou em vigor na data 28 de março de 1996. Já no preâmbulo, a Convenção aponta que a prática sistemática do desaparecimento constitui crime contra a humanidade, pois afronta hediondamente a dignidade da pessoa humana, por meio da violação de uma série de direitos humanos consagrados pela Convenção Americana de Direitos Humanos, bem como pela DUDH.

Em seu art. 2 a Convenção assim caracteriza o desaparecimento forçado de pessoas:

Para os efeitos desta Convenção, entende-se por desaparecimento forçado a privação de liberdade de uma pessoa ou mais pessoas, seja de que forma for, praticada por agentes do Estado ou por pessoas ou grupos de pessoas que atuem com autorização, apoio ou consentimento do Estado, seguida de falta de informação ou da recusa a reconhecer a privação de liberdade ou a informar sobre o paradeiro da pessoa, impedindo assim o exercício dos recursos legais e das garantias processuais pertinentes.

Internacional, Universidad de Navarra, Pamplona, 1996, pp. 497 a 500. A questão da força normativa da Declaração será desenvolvida no capítulo 2 desta dissertação.

71 BRODY, Reed e GONZALEZ, Felipe. Nunca más: an analyses of international instruments on “disappearances". In: Human Rights Quaterly, vol. 19, n. 12, The Johns Hopkins University Press, 1997, p. 375.

${ }^{72}$ Resoluções da AG/OEA: AG/doc.3072/94; AG/RES.890(XVII-0/87); AG/RES.950(XVIII-0/88); 1014(XIX0/89); AG/RES.1033(XX-0/90); AG/RES.1172(XXII-0/92). 
Os termos da Convenção dizem respeito à obrigatoriedade de os Estados-Partes não praticarem, tolerarem ou permitirem o desaparecimento, nem em estado de exceção; punirem os causadores desse fenômeno, assim como sua tentativa; além de criarem condições jurídicas, administrativas e legislativas para cumprirem com os compromissos assinalados na Convenção. Além disso, determina que devem cooperar entre si para a localização, identificação, traslado de corpos de desaparecidos.

Quanto à tipificação como crime, em seu art. 3 a Convenção determina que os Estados-Partes devem adotar as medidas legislativas necessárias para tipificar o crime de desaparecimento, considerando sua extrema gravidade, e seu caráter permanente e contínuo até que se localize o paradeiro da vítima. Ademais, autoriza a atenuação da pena do agente, a depender da sua colaboração para a elucidação dos fatos e cooperação com a investigação. Considera em seu artigo seguinte que todos os atos constitutivos do desaparecimento (seqüestro, prisão arbitrária, tortura, homicídio etc) devem ser considerados delitos em qualquer Estado, e estes são responsáveis por estabelecerem as medidas para sua jurisdição.

No mesmo sentido, a Convenção estabelece que a alegação de delito político não poderá ser considerada para os efeitos da extradição, pois o desaparecimento deverá ser incluído em todos os tratados de extradição celebrados entre os Estados, passados e vindouros, assim como, aqueles que não tiverem tratado bilateral concernente a essa matéria, poderão basear juridicamente seu pedido de extradição com fundamento na Convenção. Os Estados que não extraditarem o agente deverão exercer jurisdição como se os atos tivessem sido praticados em seus territórios, conforme estabelecido nos arts 5 e 6.

Determina a Convenção que a ação penal do crime de desaparecimento não se submeterá à prescrição, assim como a pena imposta por ela. A obediência devida não será fundamento para a prática do desaparecimento, de modo que quem receber tal ordem de algum superior hierárquico tem a obrigação de desobedecê-la. Outro aspecto relevante da Convenção é a proibição do julgamento de tais atos por jurisdições especiais, tal como a militar. ${ }^{73}$

\footnotetext{
${ }^{73}$ Convenção Interamericana sobre Desaparecimento Forçado de Pessoas, arts. 7 a 11.
} 


\subsubsection{Estatuto de Roma}

O Estatuto de Roma $^{74}$, tratado internacional que cria o TPI e define os crimes de sua competência, adotado em 1998, e em vigor a partir de 2002, classifica o desaparecimento forçado de pessoas como crime contra a humanidade em determinadas circunstâncias, em seu art. 7, parágrafo 1, i. Essa tipificação decorre de sua extrema gravidade face à violação multifacetada de direitos humanos que é inerente à prática do desaparecimento forçado.

No que se refere aos elementos do crime de desaparecimento forçado de pessoas ${ }^{75}$, estabelecidos pelo TPI com o fim de auxiliá-lo a interpretar os crimes de sua competência e aplicar as disposições concernentes a eles, considera autor aquele tenha apreendido, detido ou seqüestrado uma ou mais pessoas, ou negado a reconhecer tal ato, e consequientemente a dar informações acerca do paradeiro e sorte da pessoa, da mesma forma que essa privação de liberdade tenha sido acompanhada de uma negativa por informar o paradeiro da pessoa ou pessoas desaparecidas. $\mathrm{Na}$ mesma medida, estipula que o desaparecimento tenha ocorrido com a autorização ou aquiescência do Estado ou organização política mediante seu apoio ou autorização, além da intenção de manter o desaparecido fora do amparo da lei por período prolongado. E finalmente, que a conduta tenha sido parte de um ataque generalizado ou sistemático, dirigido contra a população civil, e o agente saiba desse fato.

O projeto "The missing" iniciado pelo Comitê Internacional da Cruz Vermelha no início dos anos 2000 visou mobilizar esforços de atores humanitários com o fim de minimizar o desaparecimento de pessoas e a angústia sofrida pelos familiares em situação de violência interna e conflitos armados. Em sua primeira fase, o Comitê desenvolveu, juntamente com instituições universitárias e especialistas, estudos acerca do fenômeno e ações possíveis para reduzir seus impactos. O resultado dessa primeira etapa foi a formulação de um conjunto de recomendações práticas sobre assuntos jurídicos e operacionais com a finalidade de ajudar a prevenir os desaparecimentos, prestar assistência aos familiares e descobrir a sorte das vítimas. $^{76}$

\footnotetext{
${ }^{74}$ Mais detalhes acerca de sua criação serão tratados no capítulo 2 da presente dissertação.

${ }^{75}$ ICC-ASP/1/3, adotado em 09.09.2002 pelos Estados Membros do TPI.

${ }^{76}$ CICR. Prácticas operacionales idóneas en relación con el tratamiento de los restos humanos y de la información sobre los fallecidos para personal no especializado. Genebra: CICR, 2004, P. 5
} 
A segunda fase, ocorrida em fevereiro de 2003 o Comitê Internacional da Cruz Vermelha promoveu uma importante Conferência reunindo mais de 350 especialistas governamentais e não-governamentais acerca da temática das pessoas desaparecidas (the missing ${ }^{77}$ ), no sentido de proposição de ações para resolver essa problemática em lugares onde houvesse conflitos armados ou distúrbios internos, e para oferecer assistência às famílias dos desaparecidos. Dessa maneira, a missão do Comitê nesta Conferência era de conscientizar e engajar os governos, militares, entidades nacionais e internacionais nas medidas para ação e comunicação com o fim de resolver a situação dos desaparecidos, além de assistirem aos familiares e prevenirem futuros desaparecimentos ${ }^{78}$.

Os objetivos da Conferência eram dar respostas mais imediatas aos familiares dos desaparecidos, incluir essa questão como prioridade na agenda dos governos, da ONU e das organizações não-governamentais, definir mecanismos e procedimentos mais eficazes para a obtenção de resultados concretos de maneira mais rápida, padronizar os métodos entre todos aqueles que trabalham com a busca de pessoas desaparecidas e reforçar o direito internacional e nacionais para evitar desaparecimentos. O Alto Comissário de Direitos Humanos das Nações Unidas, Sérgio Vieira de Melo, manifestou ser o desaparecimento forçado o problema que mais preocupa esse organismo internacional, e ressaltou a necessidade de cooperação entre todos os atores internacionais, já que os procedimentos até então aplicados para resolver esse crime estavam aquém do necessário. Expressou também em seu discurso que os instrumentos jurídicos de direito internacional dos direitos humanos e direito internacional humanitário devem ser complementares para tutelar essa questão, e finalmente que a impunidade dos perpetradores do desaparecimento, ou seja, a ausência de justiça a esse crime, é intolerável do ponto de vista da reconciliação ${ }^{79}$.

Os painéis que deram o tônus propositivo da Conferência tiveram entre as temáticas a necessidade de os familiares saberem do ocorrido com seus parentes ${ }^{80}$, a exumação e

77 The concept of "missing" in international humanitarian law is certainly much broader than that of "forced disappearance" as formulated in international human rights law. "Missing" in international humanitarian law covers all those situations in which the fate or whereabouts of a person are unknown. Estudo sobre direito à verdade ONU, E/CN.4/2006/91, p. 4.

${ }^{78}$ Conferência Internacional The missing - the right to know. www.icrc.org

${ }^{79}$ Las personas desaparecidas - Conferencia - Boletin diário n. 2 - www.icrc.org

${ }^{80}$ Além da análise dos impactos psicológicos causados aos familiares face ao desaparecimento de um ente querido, e da necessidade de receberem informações confiáveis quando do seu falecimento, a proposta advinda do painel foi de que o registro das informações relativas a mortes em caso de conflito armado ou violência interna deve ser feita de forma sistematizada pelas autoridades, entretanto, quando estas não têm condições, os 
identificação dos restos mortais ${ }^{81}$, o papel das forças e grupos $\operatorname{armados}^{82}$, e os mecanismos destinados a resolver os problemas relativos às pessoas dadas por desaparecidas ${ }^{83}$. Ao término da Conferência três aspectos essenciais foram destacados, a saber: o sofrimento das vítimas, a importância do direito como ferramenta indispensável para mitigar esse sofrimento e que a busca por maneiras de resolver o problema do desaparecimento de pessoas deveria continuar $^{84}$. Além disso, foi adotado o documento Observações e Recomendações ${ }^{85}$ acerca dessa temática, para ser difundido no plano internacional.

No mesmo ano, durante a XXVIII Conferência Internacional da Cruz Vermelha e do Crescente Vermelho, ocorrida em dezembro, foi aprovada a Resolução 1 acerca da Declaração e do Programa de Ação Humanitária, que teve como um dos quatro focos a questão das pessoas desaparecidas, em razão de conflito armado ou de outras situações de violência armada. Para tanto, o Programa estabeleceu seis objetivos relativos à questão das pessoas desaparecidas ${ }^{86}$, e todos os participantes da Conferência deveriam empreender esforços para alcançá-los no período de 2004 a 2007.

atores humanitários devem se responsabilizar pelos registros, como forma de informar aos familiares da eventual morte de seu parente desaparecido. Las personas desaparecidas - Conferencia - Boletin diário n. 3 www.icrc.org

${ }^{81} \mathrm{O}$ objetivo deste painel foi o de evidenciar a importância de um marco comum de trabalho em matéria de coleta, exumação e identificação de restos mortais, ressaltando que as atividades das autoridades estatais e grupos armados devem ter parâmetros claros e instituídos no processo de exumação, autópsia e identificação dos restos humanos. Idem.

${ }^{82}$ Reafirmou-se nesse painel que devem ser oferecidos meios de identificação dos membros das forças armadas, respeitando-se a adoção das placas de identificação que representam o mínimo absoluto de identificação em situação de conflito armado ou violência interna. Ademais, apontou sua responsabilidade no que concerne à divulgação de informações às autoridades e familiares acerca dos feridos, doentes, pessoas privadas de liberdade ou mortas. Idem.

${ }^{83}$ Este último painel tratou dos limites dos mecanismos existentes em relação à transmissão de informações acerca dos desaparecidos - de responsabilidade das autoridades estatais e dos militares, que devem agir com imparcialidade e de forma independente -, assim como essas informações devem ser rapidamente transmitidas, para que sejam exercidas as garantias jurídicas. Idem.

${ }^{84}$ Las personas desaparecidas - Conferencia - Boletin diário n. 4 - www.icrc.org

${ }^{85}$ Os termos desse documento pautam-se na necessidade de prevenção do desaparecimento, esclarecimento do ocorrido, tratamento das informações das pessoas dadas por desaparecidas, instalação de oficinas de informação encarregadas de transmitir informações assim que se iniciam os conflitos armados, tratamento dos restos mortais e das informações acerca dos mortos e sua devolução aos familiares, assistência à família e respeito aos mortos e ritos fúnebres. Informe del CICR: Las personas desaparecidas y SUS familiares - resumen de las conclusiones de consultas anteriores a la Conferencia Internacional de expertos gubernamentales y no gubernamentales (del 19 al 21 de febrero de 2003). ICRC/TheMissing/01.2003/ES/10, pp. 18-20.

${ }^{86}$ Os objetivos contidos no Programa concernente ao desaparecimento são: Evitar o desaparecimento de pessoas, esclarecer a sorte das pessoas desaparecidas, gerir as informações acerca das pessoas desaparecidas, buscar, reconhecer, identificar e tratar adequadamente os restos mortais das pessoas desaparecidas e mortas, apoiar os familiares dos desaparecidos, orientar os grupos armados e forças armadas para resolver o problema dos desaparecidos, que orientem as famílias e evitem novos desaparecimentos. Idem, pp. 23-25. 


\subsubsection{Convenção Internacional para Proteção de Todas as Pessoas contra o Desaparecimento Forçado}

Em 29 de julho de 2006 o Conselho de Direitos Humanos da ONU aprovou pela Resolução 1/1 a Convenção Internacional para Proteção de Todas as Pessoas contra o Desaparecimento Forçado, de modo que a Assembleia Geral da ONU adotou-a em 20 de dezembro do mesmo ano pela Resolução 61/177. Em seu preâmbulo a Convenção considera os documentos internacionais concernentes à garantia dos direitos humanos, em especial aqueles diretamente relacionados ao desaparecimento, como a Declaração de 1992 e o Estatuto de Roma de 1998. Ademais, salienta a gravidade do crime de desaparecimento forçado e a necessidade de empreender esforços para erradicar sua prática, pôr fim à impunidade, reparar as vítimas e conhecer a verdade acerca dos fatos concernentes ao desaparecimento.

Logo em seu art. 1, a Convenção trata da proibição absoluta ao desaparecimento forçado, de modo que nenhuma justificativa pode ser invocada para sua prática, como estados de exceção ou instabilidade interna. No mesmo sentido, determina aos Estados que tipifiquem o crime de desaparecimento em suas legislações internas, persigam os responsáveis penalmente, e estabelecem critérios para prescrição, sem prejuízo do caráter de imprescritibilidade do desaparecimento como crime contra a humanidade ${ }^{87}$. No mesmo sentido, a Convenção considera que o desaparecimento não poderá ser considerado crime político ou conexo a um crime político, nem crime inspirado por razões políticas, de forma que nenhuma solicitação de extradição poderá ser negada com base nesses fundamentos ${ }^{88}$.

Em seu art. 24 a Convenção trata do conceito de vítima, considerando que ele se aplica a todos aqueles que tiverem sofrido algum prejuízo em decorrência do desaparecimento. Também aponta o direito de conhecer a verdade sobre as circunstâncias, evolução e resultados acerca da sorte do desaparecido, obrigando os Estados a tomarem todas as medidas cabíveis para a efetiva busca e localização dessas pessoas, com o fim de devolver os restos aos familiares. Determina ademais que os Estados devem garantir o direito à reparação das vítimas, abarcando a restituição, readaptação, satisfação, indenização e garantias de não repetição. Na segunda parte da Convenção, há as diretrizes para a criação de um Comitê

\footnotetext{
${ }^{87}$ Convenção Internacional para Proteção de Todas as Pessoas contra o Desaparecimento Forçado, arts. 4-8.

${ }^{88}$ Idem, art. 13.
} 
contra o desaparecimento forçado, dedicado ao monitoramento da implementação do tratado nos Estados-Partes.

Em suma, a Convenção da ONU proíbe explicitamente o desaparecimento forçado em âmbito global. Antes dela, o desaparecimento forçado tinha sido visto apenas como uma violação de determinados direitos, tais como a proibição da tortura, o direito à liberdade ou à vida. Mas o desaparecimento forçado é mais que a soma desses diferentes aspectos. Caracteriza-se pelo aspecto específico da negação da própria existência da pessoa seqüestrada, a negação de manter as famílias informadas a respeito de seus parentes. Este aspecto é reconhecido na Convenção porque ela considera o desaparecimento forçado como uma violação em si. Dessa maneira, não obstante algumas das compreensões formadas na Declaração de 1992 e na Convenção Interamericana de 1994 não terem sido incorporadas a esta Convenção ${ }^{89}$, ela representa grande avanço para a prevenção e erradicação da prática de desaparecimento forçado em âmbito mundial.

\subsection{A contribuição do grupo de trabalho sobre desaparecimento forçado ou involuntário de pessoas da ONU e das organizações não-governamentais}

A questão dos desaparecidos ganha relevo no contexto jurídico internacional a partir da atuação dos familiares das vítimas, das organizações não-governamentais, dos órgãos das organizações internacionais da ONU e OEA. Dessa maneira, é essencial observar como esses diversos atores informam as instâncias responsáveis por desenvolver a normativa internacional no que concerne ao fenômeno do desaparecimento forçado de pessoas, questão em que os aspectos político e jurídico guardam uma relação bastante estreita, na medida em que, simplificadamente, são os governos que cometem tal crime, mas também são eles os responsáveis por erradicar esse tipo de grave violação de direitos humanos. Dessa maneira, a conscientização, a sensibilização e todos os esforços dos atores não estatais em concerto com os atores estatais constituíram e constituem atividades fundamentais para a construção jurídica do desaparecimento forçado de pessoas tendo em vista sua erradicação do mundo humano.

\footnotetext{
${ }^{89} \mathrm{Um}$ dos aspectos que não foi mencionado na Convenção, mas relevante em relação ao cotejo com os dois instrumentos anteriores, é a proibição do julgamento dos autores de desaparecimento forçado por cortes militares. Em ambos os documentos da década de 1990 há expressa determinação de que os perpetradores devem ser julgados por cortes comuns, e não por cortes militares ou especiais, e na Convenção não há menção a esse ponto.
} 
Nesse sentido, apesar do perigo que correm em suas atividades de pressão para denunciar os abusos cometidos pelos Estados, bem como para imprimir nas sociedades nacionais e comunidade internacional os princípios dos direitos humanos, organizações não governamentais e indivíduos trabalham de diversas formas para dar visibilidade à situação dos desaparecidos em seus âmbitos locais, gerando impacto global. Assim, realizam pesquisas e buscam junto às autoridades informações acerca do paradeiro dos desaparecidos, recorrem ao Poder Judiciário interpondo habeas corpus em favor das vítimas, dão assistência aos familiares das vítimas ou se constituem por elas, investigam casos individuais e documentam o alcance de tais práticas, informam o público de seus direitos a partir das normas de direito internacional $^{90}$, organizam fóruns mobilizando a opinião pública e atores governamentais para suas demandas etc.

Dessa forma, as organizações não governamentais trabalham em favor das vítimas ${ }^{91}$, no sentido de proteger e buscar a promoção de seus direitos humanos, fazendo frente às arbitrariedades de Estados incapazes de garanti-los. Da mesma maneira se organizaram os familiares de desaparecidos, que fundaram organizações em razão de sua necessidade de buscar a verdade dos acontecimentos e de evitar que novas violações de direitos humanos dessa natureza ocorram no futuro ${ }^{92}$.

Cumpre destacar a atuação do Grupo de Trabalho sobre Desaparecimento Forçado ou Involuntário da ONU que, desde 1980, desempenha um papel de canalizador de diversas demandas dessas organizações não-governamentais, bem como das vítimas individuais, fazendo a interface com os governos no sentido de clarificar os casos de desaparecimento, e com outras instâncias da ONU, sendo ator essencial para a construção normativa internacional do fenômeno.

\footnotetext{
${ }^{90}$ AMNESTY INTERNATIONAL. Desapariciones forzadas y homicídios políticos - La crisis de los derechos humanos em los noventa. Manual para la acción. Madrid: Editorial Amnistía Internacional - EDAI, 1994, p. 266.

${ }^{91}$ Como já explicitado no item 1.1, em caso de desaparecimento forçado compreende-se vítima não só a vítima de desaparecimento, mas o conceito é estendido para seus familiares, que também têm seus direitos humanos violados quando privados da convivência com seu ente querido, e de saber seu paradeiro.

${ }^{92}$ AMNESTY INTERNATIONAL. Desapariciones forzadas y homicídios políticos - La crisis de los derechos humanos em los noventa. Manual para la acción. Madrid: Editorial Amnistía Internacional - EDAI, 1994, pp. 268-9
} 


\subsubsection{O grupo de trabalho sobre desaparecimento forçado ou involuntário da ONU}

O grupo de trabalho sobre Desaparecimento Forçado ou Involuntário ${ }^{93}$ está vinculado ao Conselho de Direitos Humanos da ONU, e até 2006 exercia suas atividades a partir das determinações da extinta Comissão de Direitos Humanos. Ele tem como objetivo dar assistência aos familiares das vítimas de desaparecimentos forçados, no que diz respeito ao desvelamento dos casos. Recebe denúncias dos familiares ou seus representantes, encaminha a situação aos governos responsáveis requerendo a devida investigação, e respostas a cada caso individual. Desse modo, tem como principais funções solucionar os casos de desaparecimentos forçados, auxiliando os familiares a descobrirem o que aconteceu com as vítimas, e observar a implementação nos países das disposições da Declaração de 1992.

Esse grupo foi o primeiro mecanismo de Procedimento Temático estabelecido pela ONU, dedicado a analisar violação particular de direitos humanos, cometida em escala global. Antes disso, havia relatores ou grupos especiais para verificar situações em algum país ou território. Nos anos subseqüentes a ONU criou outros grupos de Procedimento Temático, tais como a nomeação de relatores especiais sobre execuções extrajudiciais, sumárias ou arbitrárias; para a tortura; independência dos juízes e advogados; pessoas internamente deslocadas; liberdade de opinião e de expressão; violência contra as mulheres; intolerância e discriminação baseadas na religião ou na convicção; racismo, discriminação racial e xenofobia; consequências dos produtos tóxicos e perigosos no gozo dos direitos humanos; venda de crianças, prostituição e pornografia infantis; utilização de mercenários. Foi também estabelecido o Grupo de Trabalho sobre Detenção Arbitrária. ${ }^{94}$. O total de casos transmitidos a governos pelo grupo de trabalho desde sua criação soma 52.952, e há 42.393 sob consideração, que ainda não foram solucionados, de 79 países, de acordo com o último relatório apresentado ao Conselho de Direitos Humanos ${ }^{95}$.

O método de trabalho do grupo funda-se em ser o canal de comunicação entre os governos e as famílias dos desaparecidos. Isso porque ele parte do pressuposto de que o Estado é responsável por prevenir e investigar as violações de direitos humanos ocorridas em seu território. Funciona, nesse sentido, como um facilitador para que os casos de desaparecimentos sejam solucionados. Essa característica de intervenção em defesa dos direitos das vítimas de saberem o ocorrido com seus familiares tem natureza humanitária. $\mathrm{O}$

\footnotetext{
${ }^{93}$ Cf. Fact Sheet no 6 (Rev.2).

${ }^{94}$ Idem.

${ }^{95}$ A/HRC/10/9, Summary, p. 2.
} 
grupo não se ocupa das situações de conflito armado internacional, haja vista a competência do Comitê Internacional da Cruz Vermelha em tais situações e as disposições das Convenções de Genebra e dos Protocolos Adicionais ${ }^{96}$.

Atualmente o grupo de trabalho tem mandato de três anos, e relata anualmente suas atividades ao Conselho de Direitos Humanos. Ocorrem três sessões privadas de trabalho por ano, contudo, o grupo geralmente convida representantes dos governos, instituiçõos nãogovernamentais, familiares e testemunhas para participarem dos encontros, de acordo com as necessidades e os casos analisados. Logo após as sessões do ano o grupo envia ao Conselho de Direitos Humanos um relatório contendo todos os casos em que interveio, país por país, e a situação de cada um; gráficos contendo o desenvolvimento do desaparecimento em países com mais de 50 casos denunciados; suas conclusões e recomendações. A partir de 1993 o grupo incorporou em seus relatórios anuais a situação da implementação pelos países da Declaração sobre a Proteção de todas as Pessoas do Desaparecimento Forçado, e os obstáculos encontrados para tal fim.

Em 04 de dezembro de 2008 o grupo de trabalho revisou seus métodos de trabalho, considerando que para um caso ser admissível deve ser encaminhado por um familiar, ou por alguma instituição mediante sua autorização, reafirmando não se ocupar de casos de conflito internacional. Ademais, solicita o máximo de informações possível dos denunciantes, como o nome completo, idade, profissão, sexo, nacionalidade, data e local do desaparecimento, as medidas adotadas pela família para localizar a vítima. Ao comunicar o caso ao governo, o grupo mantém relação somente com ele, por entender que é o responsável por responder pelos casos de desaparecimento. O grupo considera um caso aclarado quando o governo revela os fatos acerca do desaparecimento, ou emite uma declaração de presunção de morte, em acordo com os familiares. ${ }^{97}$

\subsubsection{O estabelecimento e a atuação do grupo de trabalho, sua relação com os Estados e as organizações não-governamentais}

\footnotetext{
${ }^{96}$ E/CN.4/1988/19, para. 18.

${ }^{97}$ A/HRC/10/9, p. 100-4, Anexo I.
} 
Em 20 de dezembro de 1978 a Assembléia Geral da ONU adotou a Resolução 33/173, que tem como objeto o desaparecimento forçado de pessoas. Em razão de diversas denúncias baseadas em arbitrariedades cometidas por governos, polícias e entidades afins, motivadas especialmente nos casos do Chipre e do $\mathrm{Chile}^{98}$, e a dificuldade de obter informações acerca dos casos, a Assembléia determinou aos governos, à Comissão de Direitos Humanos e ao Secretário-Geral que despendessem esforços para investigar o que estava acontecendo em relação ao assunto. O Conselho Social e Econômico da ONU, por meio da Resolução 1979/38, de 10 de maio de 1979, estabeleceu que o desaparecimento forçado de pessoas deveria ser prioridade nos trabalhos da Comissão de Direitos Humanos, assim como a Resolução 5 B (XXXII), adotada em 5 de setembro de 1979, pela Sub-Comissão para Prevenção da Discriminação e Proteção das Minorias.

Dessa maneira, em 29 de fevereiro de 1980, a Comissão de Direitos Humanos, pela Resolução 20 (XXXVI), decidiu criar, pelo período de um ano, um grupo de trabalho composto de cinco membros, com o fim de apontar e examinar as questões atinentes ao desaparecimento forçado de pessoas. De acordo com essa Resolução, o grupo de trabalho deveria colher informações junto aos governos, organizações não-governamentais, humanitárias, e outras fontes confiáveis, e, ao término do período, na $37^{a}$. sessão da Comissão de Direitos Humanos, entregar um relatório das atividades, somado às conclusões e recomendações.

Durante a $33^{\mathrm{a}}$. sessão da Sub-Comissão para Prevenção da Discriminação e Proteção das Minorias, na Resolução 18 (XXXIII), declarou-se a importância de estender o mandato do grupo de trabalho, face à gravidade do fenômeno do desaparecimento forçado de pessoas, e ressaltou a urgência de ações de outros órgãos da ONU, em colaboração aos trabalhos do grupo. No mesmo ano, em 15 de dezembro, a Assembléia Geral da ONU, na Resolução 35/193, expressou sua receptividade quanto à atuação do grupo de trabalho e reafirmou a necessidade da cooperação dos governos.

Em sua primeira sessão, o grupo procurou delimitar seu escopo e métodos de atuação. Decidiram na ocasião que teriam três sessões, e, por meio da sumarização dos casos, buscariam informações acerca do ocorrido, e também da sua situação atual. Assim, além da cooperação dos outros órgãos da ONU, o grupo procurou estabelecer uma relação com os

\footnotetext{
${ }^{98}$ Cf. primeiro relatório do Grupo de Trabalho sobre Desaparecimento Forçado ou Involuntário, E/CN.4/1435.
} 
governos, entidades não-governamentais, de assistência humanitária, visando obter informações. Por isso sua abordagem deixava claro que não se pretendia julgar o ocorrido, mas desvelar os casos, e encontrar soluções para o problema dos desaparecidos. Decidiram, dessa maneira, que suas ações seriam desenvolvidas com espírito humanitário. "Apenas os casos antigos devem ser investigados, quaisquer outros potenciais devem ser prevenidos" 99 . Importante notar que os familiares têm um papel fundamental no envio de informações acerca dos desaparecimentos desde o princípio.

O grupo de trabalho realiza suas atividades em três níveis diferentes. Na maior parte o grupo se ocupa de casos individuais, ajudando os parentes a descobrirem a sorte e o paradeiro de seus entes queridos. Em um segundo nível, o grupo estuda a situação de desaparecimento em determinados países, apresentando suas observações e recomendações, assim como informes especiais em caso de visita. Em terceiro lugar, observa o fenômeno do desaparecimento forçado em si, sua dinâmica e dimensões ${ }^{100}$.

No primeiro relatório ${ }^{101}$, entregue em 26 de janeiro de 1981, o grupo de trabalho priorizou sistematizar e analisar as denúncias recebidas antes do início de suas atividades. Também teve como foco os países em que a prática do desaparecimento forçado havia se tornado comum. Desse modo, o grupo deparou-se com um número entre 11.000 e 13.000 casos, especialmente dos países: Argentina, Bolívia, Brasil, Chile, Chipre, El Salvador, Etiópia, Guatemala, Indonésia, México, Nicarágua, Peru, Filipinas, África do Sul e Uruguai. Os casos foram reportados por diversos atores, como os próprios governos, entidades não governamentais, familiares das vítimas, organizações intergovernamentais, pessoas que testemunharam as ações, e até mesmo as envolvidas com o crime em questão ${ }^{102}$. Inicialmente, o grupo de trabalho enviou uma carta aos governos em que casos de desaparecimento forçado haviam sido conhecidos, anunciando suas atividades, propondo que fizessem uma visita a esses países $^{103}$.

Os casos considerados pelo grupo de trabalho foram aqueles em que as pessoas desaparecidas não constavam em nenhum registro oficial de prisão ou morte, o que levava então à presunção

\footnotetext{
${ }^{99}$ Just older cases must be investigated, so, too, news must be prevented. E/CN.4/1435, p. 08, para 10.

${ }^{100}$ E/CN.4/1990/13, p. 90, para, 148.

${ }^{101}$ E/CN.4/1435.

${ }^{102}$ E/CN.4/1435, p. 21, para. 44

${ }^{103}$ E/CN.4/1435, p. 16, para. 31.
} 
de sua detenção arbitrária e possível assassinato. Dessa maneira, à parte os casos em que a pessoa foi reportada morta, não havia evidência suficiente para saber se o desaparecido estava vivo ou morto ${ }^{104}$. Dessa maneira, o grupo de trabalho, incapaz de acompanhar todos os casos reportados, estabeleceu algumas prioridades, como por exemplo a submissão do caso por algum familiar ou alguma organização, pois não teria condições . O grupo não teria condições de verificar todos os casos ocorridos, por isso ele recebe as denúncias para então atuar. Contudo, o grupo tem especial interesse nos casos de Estados em que a utilização da desaparição forçada é sistemática, e aqueles que ocorrem em países que eventualmente não saibam da atuação e existência do desse mecanismo ${ }^{105}$.

Diversas conferências sobre desaparecimento forçado foram realizadas por entidades não governamentais em 1981. O grupo de trabalho assinalou a relevância do primeiro e segundo ${ }^{106}$ Congresso Latino Americano dos Familiares das Pessoas Desaparecidas. Diversas entidades não governamentais passaram a enviar suas intenções de colaborar com as atividades do grupo. Ademais, a questão do desaparecimento passou a ser discutida em seminários e pela mídia em geral ${ }^{107}$, demonstrando a visibilidade que esse fenômeno começou a ganhar em escala mundial.

As observações deste primeiro relatório evidenciaram que o problema do desaparecimento forçado de pessoas é bastante complexo, e as circunstâncias variam de acordo com o contexto de cada o país. É gravíssimo pois viola uma série de direitos da pessoa desaparecida, como a vida, a liberdade, a integridade física, mas também estende à família grande angústia por não saber o ocorrido com o desaparecido. Além disso, é uma questão persistente, na medida em que as denúncias foram recebidas ao longo de anos, e não cessaram durante as atividades do grupo. Constatou-se também que o método de trabalho desenvolvido é pertinente para investigar os casos, e uma estratégia para a cessação desta prática de violação de direitos humanos. Recomendou, desse modo, que a Comissão de Direitos Humanos, e a ONU de um modo geral, continuassem a dar estreita atenção à questão do desaparecimento forçado de pessoas $^{108}$.

\footnotetext{
${ }^{104} \mathrm{E} / \mathrm{CN} .4 / 1435$, p. 06.

${ }^{105} \mathrm{E} / \mathrm{CN} .4 / 1435$, p. 07

${ }^{106} \mathrm{Um}$ representante do grupo de trabalho participou do segundo congresso, a convite dos familiares. Deste encontro criou-se a Federação Latino-Americana de Associação de Familiares de Pessoas Desaparecidas (FEDEFAM). E/CN.4/1435, p. 8, para. 23.

${ }^{107} \mathrm{E} / \mathrm{CN} .4 / 1435$, p. 8 , para 24.

${ }^{108}$ E/CN.4/1435, p. 82-3 , seção 6.
} 
Em 26 de fevereiro de 1981 a Comissão de Direitos Humanos, por meio da Resolução 10 $(\text { XXXVII })^{109}$ estendeu o mandato do grupo de trabalho por mais um ano, decisão referendada pelo Conselho Econômico e Social, na Decisão 1981/139 ${ }^{110}$ de 08 de maio do mesmo ano. No segundo relatório ${ }^{111}$, datado de 31 de dezembro de 1981, o grupo de trabalho dedicou-se a investigar especialmente dois aspectos, as crianças desaparecidas ${ }^{112}$, e a situação dos casos antes do estabelecimento do grupo. Neste mandato foi marcada a primeira visita do grupo de trabalho ao México, em janeiro de 1982. No relatório em debate foram tratadas denúncias de casos de desaparecimentos dos seguintes países: Argentina, Bolívia, Brasil, Chile, Chipre, El Salvador, Etiópia, Guatemala, Guiné, Honduras, Indonésia, Irã, Lesoto, México, Nicarágua, Filipinas, Sri Lanka, Uganda, Uruguai e Zaire ${ }^{113}$.

Cumpre apontar também a continuidade das denúncias e o aumento da colaboração das instituições e familiares no que concerne à disponibilização de informações. Desse modo, o grupo examinou informações de aproximadamente 2.100 pessoas desaparecidas, e pediu esclarecimentos aos respectivos governos de 1.950 desses casos, até aquele ano. Apesar do elevado número de casos levados à apreciação do grupo, considerou-se que o número poderia ser bastante inferior à realidade, e as hipóteses disso eram o desconhecimento da atuação do grupo em certos países, e as ameaças sofridas pelos familiares e advogados, como instrumento de represálias pelas denúncias ${ }^{114}$.

Dessa maneira, o grupo observou a dificuldade dos familiares e entidades de buscarem seus familiares, face à inatividade dos sistemas de justiça, que não tinham acesso às ações das forças militares, prejudicando o exercício dos cidadãos de praticarem suas liberdades constitucionais, inclusive porque os agentes do poder judiciário poderiam sofrer alguma represália em caso de buscarem investigar os fatos relativos aos desaparecimentos ${ }^{115}$. Essa submissão do Judiciário ao Executivo foi característica dos regimes autoritários, e a principal

\footnotetext{
${ }^{109}$ E/CN.4/1492.

${ }^{110} \mathrm{E} / \mathrm{CN} .4 / 1492$.

${ }^{111}$ E/CN.4/1492.

${ }^{112} \mathrm{O}$ desaparecimento de crianças foi estratégia bastante corrente na Argentina. O grupo recebeu um relatório da Associação de avós de crianças desaparecidas deste país, em setembro de 1981, apontando o desaparecimento de 77 crianças, tanto de adolescentes, quanto de mulheres grávidas que foram detidas e conseqüentemente suas crianças desapareceram. E/CN.4/1492, paras. 39 e 40.

${ }_{113}^{11}$ E/CN.4/1492, p. 11, para. 32.

${ }^{114}$ E/CN.4/1492, p. 11, para. 32.

${ }^{115}$ E/CN.4/1492, pp. 71-2, para. 182.
} 
razão porque aquele poder não teve atuação na tentativa de desvelamento dos desaparecimentos dizia respeito à retaliação que poderia sofrer do governo em exercício.

Diversos casos levados à apreciação do grupo de trabalho dizem respeito a pessoas desaparecidas em territórios dos quais não eram nacionais. Em muitos deles foi alegada a colaboração das forças de segurança dos países ${ }^{116}$. Esta situação de que forças de segurança operavam fora de seu território nacional, em cooperação com as outras forças de segurança, formando uma rede de apoio para perseguir e desaparecer com opositores aos regimes autoritários, chamou a atenção da comunidade internacional ${ }^{117}$. Isso porque, a despeito da construção internacional para proteção das pessoas em qualquer lugar do mundo ${ }^{118}$, esse tipo de colaboração para perseguir pessoas reinventa o que durante o período nazista autorizou o extermínio daqueles que não tinham a proteção do seu Estado nacional. Nesse período de ditaduras latino-americanas as pessoas não só foram perseguidas por seus próprios Estados, mas também em outros em que fossem buscar proteção, já que eles estavam operando em rede para buscar aqueles que eram contra o sistema.

$\mathrm{O}$ artigo $4^{\circ}$ do Pacto de Direitos Civis e Políticos garante direitos às pessoas em caso de estado de emergência e estado de sítio. Apesar de os Estados suspenderem determinados direitos humanos quando decretam estados de exceção, o direito internacional protege o direito à vida, a proteção contra a tortura e outros atos cruéis ou degradantes e o reconhecimento de todas as pessoas perante à lei como inderrogáveis, em qualquer situação $^{119}$. O grupo de trabalho identificou diversos casos de juízes persistentes e outros agentes que trabalharam no sentido de garantir os direitos estabelecidos pelo Pacto, mesmo sofrendo restrições em sua atuação e ameaças ${ }^{120}$.

Neste relatório o grupo enfatizou a importância de os governos investirem no registro de todas as informações acerca das pessoas presas, para que as famílias e todos os interessados pudessem ter acesso aos acontecimentos relativos aos desaparecimentos. Além disso, evidenciou que as prisões e julgamentos deveriam ser realizados exclusivamente pelas

\footnotetext{
${ }_{116}^{116}$ E/CN.4/1492, p. 61, para. 152.

${ }_{117}^{11}$ E/CN.4/1492, p. 62, para. 157.

${ }^{118} \mathrm{Cf}$. art. 14 da DUDH relativo ao direito a asilo político, e art. 33 do Estatuto do Refugiado.

${ }^{119}$ E/CN.4/1492, p. 72, para. 182.

${ }^{120}$ E/CN.4/1492, paras. 276-293.
} 
autoridades legítimas $^{121}$. Todas as suas recomendações dirigem-se à aplicação das legislações nacionais unicamente, não sendo necessário realizar nenhuma emenda, pois os direitos violados não eram reconhecidos somente pelo direito internacional, mas estavam previstos internamente ${ }^{122}$.

O terceiro relatório do grupo de trabalho, adotado em 10 de dezembro de 1982 foi apresentado na 39 . Sessão da Comissão de Direitos Humanos. Durante este ano o grupo optou por sumarizar todos os casos recebidos, e iniciar a organizar as estatísticas relativas aos casos admitidos, transmitidos aos governos ${ }^{123}$ com o intuito de obter informações acerca dos desaparecimentos, as respostas para solucioná-los e outras respostas. Observou-se também menos resistência dos governos em cooperar com as atividades do grupo, assim como as denúncias dos casos por parte das organizações não-governamentais tornaram-se mais freqüentes e mais céleres, provavelmente pela consolidação do grupo de trabalho no cenário mundial de proteção de direitos humanos, sobretudo por sua característica humanitária ${ }^{124}$. Neste ano de trabalho o grupo não recebeu convites para visitar nenhum país, contudo, acompanhou o congresso da FEDEFAM em Lima, Peru, em que se adotou um projeto de Convenção sobre desaparecimento forçado de pessoas, e dois membros foram verificar a situação no Chipre. ${ }^{125}$

O grupo de trabalho apontou também os esforços empreendidos pelos Estados para localizar as pessoas desaparecidas, que surgiram especialmente após as recomendações da comunidade internacional, como por exemplo em El Salvador houve o estabelecimento de uma comissão especial para investigação dos prisioneiros políticos e desaparecidos em 1979, e na Bolívia a comissão nacional para investigação das pessoas desaparecidas foi instituída em 1982. A associação de familiares FEDEFAM sugeriu que fosse observado se as comissões internas que estavam sendo criadas para investigar os casos de desaparecimento obedeciam a certos critérios, tais quais a independência dos membros em relação ao Poder Executivo e às forças armadas, se eram parte do Poder Judiciário, e se os casos já haviam sido apresentados a ele no passado, o nível de poder investigativo da comissão, se ela tinha acesso aos centros de detenção ou apenas às informações do governo, e se os familiares das vítimas obtiveram

${ }^{121}$ E/CN.4/1492, p. 72, para. 184.

${ }^{122} \mathrm{E} / \mathrm{CN} .4 / 1492$, p. 73 , para. 185.

${ }^{123}$ Foram transmitidos casos aos governos da Argentina, Bolívia, Chipre, El Salvador, Guatemala, Honduras, Indonésia, México, Nicarágua, Filipinas e Uruguai, em que houve mais de vinte denúncias de desaparecimento

${ }^{124} \mathrm{E} / \mathrm{CN} .4 / 1983 / 14$, pp. 1-2, para. 1-7.

${ }^{125}$ E/CN.4/1983/14, p. 5, para. 19. 
informações acerca do paradeiro de suas vítimas. Além disso, propôs que a ONU acompanhasse e ajudasse a formar as comissões nacionais de investigação para justamente evitar que elas fossem constituídas de forma arbitrária e não atingissem os objetivos que eram identificar os acontecimentos acerca dos desaparecimentos ${ }^{126}$.

O relatório apresentado à Comissão de Direitos Humanos em 1985, de acordo com as diretrizes estabelecidas por sua Resolução 1984/23, que estendeu o mandato de trabalho do grupo, sumarizou os casos recebidos e transmitidos dos países que estabeleceram relação com o grupo, elencando o número de pessoas desaparecidas, quantas denúncias haviam sido realizadas pelos familiares, por não-familiares, o número de casos solucionados e quantos ainda restavam desvelar ${ }^{127}$. Com esse material disponível o grupo verificaria as principais características e medidas tomadas para atender à Resolução 133/73 da Assembléia Geral ${ }^{128}$. Dessa maneira, para continuar os esforços no sentido de solucionar os casos e prevenir o desaparecimento de pessoas, o grupo aprimorou seus métodos de trabalho ${ }^{129}$ e adotou algumas estratégias para estreitar sua relação com os governos, tais quais a retransmissão dos casos sumarizados que ainda não tivessem sido solucionados, a requisição de informações sobre o resultado das investigações, o requerimento de que o governo esclarecesse as informações enviadas pelas entidades não-governamentais, e a solicitação de visita aos países pelo grupo $^{130}$.

A Anistia Internacional, em carta ao grupo de trabalho datada de 24 de setembro de 1984, expressou sua preocupação quanto ao não cumprimento pelos países da Resolução 133/73. Observou que os países não estavam investigando com imparcialidade e celeridade os casos de desaparecimento, que não estavam sendo implementadas medidas contra os perpetradores para evitar que continuassem a praticar tal violação, que não estavam promovendo os direitos humanos das vítimas, e a cooperação com as entidades internacionais para um esforço conjunto de localização dos desaparecidos não estava sendo efetiva. No sentido de

\footnotetext{
${ }^{126}$ E/CN.4/1983/14, pp. 59 a 61, paras. 162-7.

${ }^{127}$ E/CN.4/1985/15/Add 1.

${ }^{128}$ E/CN.4/1985/15, p. 13, paras. 43-5.

${ }^{129}$ No sentido de sumarizar os casos para transmissão aos governos, o grupo de trabalho devia tomar o cuidado de triá-los, considerando que também eram recebidos em gravações, e não identificar os familiares das vítimas, que pediam sigilo. Além disso, geralmente necessitava pedir informações adicionais pois nem sempre o caso reportado já continha todos os elementos para pedir explicações aos governos. A organização dos casos continha o nome da pessoa desaparecida, a data e o lugar da detenção e o responsável se sabido, se não, a data e local aproximados e as circunstâncias do desaparecimento. E/CN.4/1985/15, p. 24, para 85-7.

${ }^{130}$ E/CN.4/1985/15, p. 23, para. 79.
} 
aperfeiçoamento das investigações nos países, para cumprimento da Resolução em destaque, essa entidade propôs que o grupo de trabalho visitasse os países para ajudar a investigar os casos e prevenir futuros desaparecimentos, que a Assembléia Geral ou a Comissão de Direitos Humanos da ONU enviasse observadores pela para regiões onde os desaparecimentos ocorriam com mais freqüência, com o fim de monitorar o problema e auxiliar os governos a controlar a situação, e que fosse levado à Comissão de Direitos Humanos os países que não estivessem cooperando com as atividades do grupo de trabalho, para ações mais incisivas. ${ }^{131}$

Durante seu $14^{\circ}$ encontro em São José, Costa Rica de 03 a 11 de outubro de 1984, a FEDEFAM fez uma análise da situação na América Latina. Distinguiu a situação dos países em quatro regimes, ditaduras militares, ditaduras em estilo antigo (como Paraguai e Haiti), governos constitucionais seguidos de ditaduras e governos constitucionais, e entendeu que o desaparecimento era fenômeno em todos os regimes, não apenas naqueles em ditadura. Sugeriu, então, que medidas em diversos níveis deveriam ser tomadas, como o encorajamento às famílias e entidades não governamentais, reformas judiciais e constitucionais, inclusão do desaparecimento forçado como crime nos códigos penais internos, e o estabelecimento de institutos forenses para identificação dos corpos das vítimas. No sentido de otimização da atuação do grupo de trabalho, propôs que este visitasse os países para verificar a situação constitucional e jurídica e o estado das instituições, e estreitasse a relação com os familiares e entidades não-governamentais, além de estimular a criação de comissões nacionais para investigar os casos. Também incentivou que o grupo desse visibilidade aos casos não solucionados pelos governos, para pressioná-los frente à comunidade internacional, e que estimulasse a criação de uma campanha internacional contra o desaparecimento forçado, para mobilizar a opinião pública. ${ }^{132}$

A FEDEFAM revisou seu projeto de Convenção sobre o desaparecimento forçado de pessoas adotada na conferência do ano anterior, e propôs que o grupo de trabalho analisasse e empreendesse esforços para recomendar sua adoção pela ONU. Nesta versão, o projeto focava não apenas as circunstâncias das pessoas desaparecidas, mas envolvia a detenção das vítimas. Apontou todos os direitos violados que compõem o desaparecimento forçado, bem como todos os atos ou omissões empreendidos para realizar o desaparecimento. Previu duas jurisdições para julgamento dos atos constitutivos da violação, em âmbito nacional e

${ }^{131}$ E/CN.4/1985/15, pp. 13-4, paras. 46-7.

${ }^{132}$ E/CN.4/1985/15, pp. 11-2, paras. 38 a 40; anexo II, pp. 1 a 7. 
internacional, classificando-a como crime contra a humanidade. A definição do desaparecimento forçado nesse projeto é a seguinte: "Desaparecimento forçado de pessoas significa qualquer ato ou omissão que é empreendido para ocultar o paradeiro de um dissidente ou oponente político, surpreendendo seus familiares e amigos, e é cometido por agentes do governo, com o intuito de suprimir, prevenir e impedir, com suporte e permissão do poder estabelecido" $" 133$.

De maneira experimental, a Comissão de Direitos Humanos, na Resolução 1986/55 de 13 de março de 1986, prorrogou o mandato do grupo de trabalho por 2 anos, face à recomendação do próprio grupo. ${ }^{134}$ Neste ano de 1986 o grupo não conseguiu realizar as três sessões, parte de seus métodos de trabalho, em virtude da crise econômica sofrida pela ONU. Contudo, realizou sua segunda visita ao Peru ${ }^{135}$, graças à colaboração de seu governo, que em 1985 criou uma Comissão de Paz ligada à Presidência da República, com o foco de investigar as graves violações de direitos humanos ocorridas durante o período ditatorial. Essa colaboração de um governo é retrato do aumento da cooperação dos Estados com as atividades do grupo de trabalho, que cada vez mais se dispuseram a responder as comunicações e estabelecer algum tipo de diálogo ${ }^{136}$.

Na mesma perspectiva, o novo governo constitucional da Guatemala, instituído em 1986, convidou o grupo a visitar seu país, devido a milhares de comunicações de desaparecimento que o grupo havia recebido nas duas décadas anteriores, além de este país ter sido o precursor da prática sistemática de desaparecimento forçado de pessoas, configurando-se como exemplo de repressão aos seus vizinhos latino-americanos ${ }^{137}$. Em uma seqüência de visitas do grupo de

${ }^{133}$ E/CN.4/1985/15, pp. 12-3, paras. 41 e 42, Art. 2. Projeto FEDEFAM, anexo III, p. 1. In the present Convention, the enforced disappearance of persons means any act or omission witch is designed to conceal the whereabouts of a political opponent or dissident, of whose fate his family, friends or supporters are unaware, and it is committed with intent to suppress, prevent or impede opposition or dissidence by persons in government office, by government officials at any level or by organized groups of private individuals acting with support or permission of the foregoing.

${ }^{134}$ E/CN.4/1987/15, p. 2, para. 6.

${ }^{135}$ E/CN.4/1987/15, p. 3, para. 9, E/CN.4/1987/15/Add.1. A primeira visita feita pelo grupo de trabalho ocorreu em junho de 1985 (E/CN.4/1986/18/Add.1), e foi notória a diferença entre a postura do antigo governo, que não assumia a responsabilidade pelos abusos dos agentes estatais, da do novo presidente García Pérez, quando afirmou que não combateria "a barbárie com barbárie", expresso pelas reformas na administração pública no sentido da transparência e imparcialidade. Contudo, as ações das forças armadas no sentido de liquidar o grupo Sendero Luminoso ainda eram contrárias às novas diretrizes governamentais.

${ }^{136}$ E/CN.4/1987/15, pp. 48 e 49, paras. 123-4.

${ }^{137}$ E/CN.4/1988/19/Add. 1, p. 24, para. 86. Assim como no Peru, o grupo observou em sua visita ocorrida em outubro de 1987, que a transição para um regime democrático abriu as portas do país para a verificação da situação de direitos humanos por parte da comunidade internacional e, apesar das propostas de reestruturação das legislações e instituições públicas, ainda havia muitas práticas de violação dos direitos, mas, no próprio dizer do 
trabalho a países, o seguinte a convidá-lo foi a Colômbia ${ }^{138}$, oportunidade em que o grupo reafirmou a importância de investigar os crimes e responsabilizar penalmente os perpetradores do desaparecimento forçado, como forma de evitar outros desaparecimentos ${ }^{139}$.

Muitos governos propuseram ao grupo de trabalho que fosse feito um comparativo da situação de desaparecimento forçado nos países sob um regime militar repressivo com os governos eleitos $^{140}$. Nesse sentido, é interessante observar que há uma abertura à comunicação dos países da América Latina na segunda metade da década de 1980 com o grupo e demais organismos internacionais, possivelmente em razão do término dos regimes ditatoriais e início da instituição de governos democráticos.

Em 1988 o grupo de trabalho recebeu uma "Declaração sobre a preocupação que inspira a prática de desaparecimentos forçados visando a sua suspensão, proibição e supressão definitiva”, da Coalizão de Organizações Não-Governamentais, conjunto de organizações de direitos humanos, sobre a impunidade dos violadores de direitos humanos, que continha os seguintes termos: a responsabilidade do Estado é contínua, independentemente da mudança de governo, e sua ação para localizar o paradeiro da vítima deve seguir até o cumprimento do objetivo, além de proporcionar reparações pecuniárias aos familiares; que todos os comandantes do governo, bem como das forças armadas devem ser responsabilizados pelas ações ou omissões relativas à execução do desaparecimento, e não devem ser agraciados com anistia, asilo político, e devem ser submetidos à extradição, assim como ter os direitos políticos suspendidos até que se aclare sua situação, e não podem escusar-se com justificativa de cumprimento de ordens superiores. ${ }^{141}$

grupo: "Não é razoável esperar que uma nação que passou por 20 anos de carnificina mude radicalmente da noite para o dia".

${ }^{138}$ Logo em seguida o grupo foi convidado para visitar El Salvador, Sri Lanka e Filipinas. E/CN.4/1990/13, p. 3, para. 10.

${ }_{139}$ E/CN.4/1989/19/Add.1. A visita a Colômbia ocorreu em novembro de 1988, ocasião em que o grupo verificou a realidade conturbada do país em razão das tensões provocadas pelo tráfico de drogas como elemento fundamental para a situação de violência. Todavia, baseado nas evidências das denúncias, o grupo concluiu que os casos de desaparecimento eram frutos da ação das forças armadas e de segurança, ou seja, executados por agentes do Estado. Outro elemento expressivo é a curta duração dos casos de desaparecimento, que, a princípio poderiam ser confundidos com execuções extrajudiciais - a pessoa desaparecia e era encontrada horas ou dias depois com o corpo marcado por torturas e mutilações. Esse tipo de ação mais característica de execução extrajudicial passou a ser mais recorrente no final dos anos 1980, razão porque o grupo de trabalho passou a envolver o Relator Independente para Execuções Sumárias ou Arbitrárias na apreciação dos casos, já que entende ter havido a clarificação da questão de desaparecimento. E/CN.4/1989/19, p. 5, para 16.

${ }^{140}$ E/CN.4/1988/19, p. 70, para. 241.

${ }^{141}$ E/CN.4/1989/18, p. 5, para. 14. 
O grupo de trabalho acompanhou diversas propostas de projetos de lei nos países latinoamericanos, por vezes iniciativas das assembléias legislativas, outras de organizações nãogovernamentais, que pretendiam criar em suas legislações a tipificação do desaparecimento como crime, na compreensão que vinha se formando nesse momento acerca dos reflexos da impunidade na persistência de tal prática ${ }^{142}$. Contudo, apesar dessas iniciativas, o grupo recebeu informes de que diversos países estavam promulgando leis de anistia que preconizavam a impunidade contra as sanções legais aos violadores de direitos humanos, inclusive aos responsáveis pelos desaparecimentos ${ }^{143}$.

A questão da impunidade passou a ser motivo de análise do grupo de trabalho que, a despeito de seu fundamento humanitário, postulava a relação direta entre a continuidade do fenômeno com a falta de punição aos perpetradores. Além disso, a ausência de sistemas de justiça e sua substituição por tribunais militares, assim como instituições públicas incapazes de responder aos familiares e à sociedade o paradeiro do desaparecido, e vedar esse crime, contribuíam para a permanência desse tipo de estratégia repressiva. Da mesma maneira, a concessão de anistia ou perdão a perpetradores de graves violações de direitos humanos, sob o manto de promover a reconciliação e pacificação social, obsta a investigação, responsabilização e repetição de tais atos. ${ }^{144}$

A Comissão de Direitos Humanos, durante sua $48^{\circ}$. Sessão, decidiu estender o mandato do grupo de trabalho por três anos por meio da Resolução 30/1992, com o fim de que tivesse tempo suficiente de conhecer e encaminhar todos os casos. Todavia, continuou-se com a obrigação de enviar um relatório anual, como já vinha sendo feito ${ }^{145}$. Como nos anos anteriores, o grupo de trabalho seguiu recebendo denúncias de diversos países, com números expressivos do Peru, Colômbia, Sri Lanka e Iraque, sendo que em muitos países o mero fato de entidades e agentes do Poder Judiciário relatarem os casos gerou retaliações e represálias, tanto em relação a perseguições pessoais quanto ao afastamento de cargos. Ademais, apesar de alguns países já estarem em regimes democráticos, as investigações dos casos de desaparecimento não estavam sendo feitas, bem como as informações das forças armadas acerca dos fatos ocorridos não haviam sido reveladas. Contudo, grupos parlamentares,

${ }^{142}$ E/CN.4/1989/18, p. 86, para. 312.

${ }^{143}$ E/CN.4/1990/13, p. 6, para. 23.

${ }^{144}$ E/CN.4/1991/20, pp. 97-8, paras. 406-410. Impunity is perhaps the single most important factor contributing to the phenomenon of disappearance. Perpetrators of human rights violations, whether civilian or military, become all the more irresponsible if they are not held to account before a court of law.

${ }^{145}$ E/CN.4/1993/25, p. 4, para. 12. 
entidades não-governamentais de alguns países informaram o grupo de trabalho que estavam pressionando seus governos a definirem o desaparecimento como crime em suas legislações internas. $^{146}$

A ação do grupo de trabalho em relação à impunidade ${ }^{147}$ dos perpetradores dos desaparecimentos forçados foi no sentido de enviar de $\operatorname{cartas}^{148}$ aos Estados-Membros da ONU e às organizações não governamentais solicitando que apontassem como ela afetava a continuidade do cometimento desse fenômeno. Atendendo o incentivo da Comissão de Direitos Humanos na Resolução 30/1992 o grupo enviou uma segunda carta àqueles Estados que não haviam respondido, considerando a importância do habeas corpus, instrumento mais célere e efetivo para prevenir desaparecimentos e identificar os responsáveis pela prisão arbitrária; a necessidade de uma administração de justiça adequada para que haja identificação e responsabilização do agente, bem como a proteção de todas as pessoas envolvidas na investigação dos casos de desaparecimento; a urgência de considerar todos os atos constitutivos do desaparecimento como crimes definidos pelas legislações penais ${ }^{149150}$, assim como a revogação de qualquer imunidade ou anistia a quem praticou tais atos; a obediência da persecução penal aos princípios internacionalmente reconhecidos, como o do devido processo legal, e o julgamento de tais crimes em cortes civis ${ }^{151}$, a despeito de o agente ser militar; a invalidade de escusas face à obediência devida e a acuidade de tornar público os resultados das investigações, como modo de estabelecer um governo accountable. ${ }^{152}$

Durante o ano de 1991 diversas organizações não governamentais relataram a descoberta de cadáveres em valas comuns, bem como a necessidade de exumação e reconhecimento dos corpos, haja vista que eles poderiam ser de desaparecidos. As respostas a essa intenção

\footnotetext{
${ }^{146}$ E/CN.4/1993/25, pp. 8-9, paras. 30 a 35, Uma situação de destaque neste momento é a da Iugoslávia que, em situação de guerra civil, vinha produzindo milhares de pessoas refugiadas, deslocadas e desaparecidas; Cf. E/CN.4/1993/25, pp. 09-11, paras. 36-44.

${ }^{147}$ Em resposta à carta, o Chile elencou impunidade moral e política, além daquela no sentido de julgamento e punição penal dos agentes. A impunidade política seria a legitimação dos atos de violação de direitos humanos de funcionários públicos, que exerceram suas atividades de modo a combaterem o "crime", e por isso foram congratulados. Por sua vez, a impunidade moral seria aquela em que o Estado justificaria os atos de seus agentes para conter a "subversão" ou defender a pátria como heróicos. E/CN.4/1993/25, p. 131, para. 26.

${ }_{148} \mathrm{E} / \mathrm{CN} .4 / 1992 / 18$, pp. 6 e 7 , para 22.

${ }^{149} \mathrm{O}$ único país neste momento a ter em sua legislação a previsão da proibição do desaparecimento forçado era a Colômbia. E/CN.4/1993/25, p. 127, para 6.

${ }^{150} \mathrm{O}$ Chile defendeu em sua resposta que o crime de desaparecimento deveria ser considerado como crime continuado, só sendo encerrado quando a vítima fosse encontrada. E/CN.4/1993/25, p. 128, para. 15.

${ }^{151}$ Países como Colômbia e Bolívia concordaram em parte com esta consideração, pois suas legislações internas previam a atuação das cortes militares quando militares cometiam crimes.

${ }^{152}$ E/CN.4/1993/25, paras. 45-6, pp. 11-2.
} 
variavam de acordo com os países, e havia desde aqueles em que instituições públicas financiavam e cooperavam com os familiares no processo de exumação e identificação até aqueles que não participavam e ameaçavam as pessoas e entidades envolvidas nesse processo. Desse modo, as organizações não governamentais afirmaram que a tentativa dos governos de ocultar o ocorrido não contribuiria em nada para a prevenção de futuros desaparecimentos. ${ }^{153}$

Na Resolução da Comissão de Direitos Humanos 24/1992, foi sugerido ao grupo que dialogasse com organizações do campo das ciências forenses, que consultou a American Association for the Advancement of Science, ao Physicians for Human Rights e ao Grupo de Antropologia Forense da Argentina, cujas experiências em missões para exumar e identificar vítimas de graves violações de direitos humanos eram reconhecidas internacionalmente, além do fato de estas organizações terem as técnicas mais modernas para esse tipo de localização, oferecendo cursos e treinamentos a organizações em diversos locais de seus países. Neste primeiro momento o grupo consultou médicos e antropólogos forenses, mas visualizava a necessidade de consultar profissionais de áreas correlatas. ${ }^{154}$

Em dezembro de 1992 a Anistia Internacional lançou o Programa de 14 Pontos para Prevenir os Desaparecimentos Forçados, a partir da campanha mundial da organização em prol da eliminação dos desaparecimentos forçados, na tentativa de envolver organizações nãogovernamentais para promoverem juntas o Programa. São os pontos: a intolerância estatal ao desaparecimento como diretriz política; a responsabilidade dos oficiais e agentes que comandarem ações de desaparecimento; o recebimento exato das informações relativas à situação dos desaparecidos pelos familiares e advogados; a criação de condições jurídicas, por parte dos governos, para que os familiares saibam do paradeiro do desaparecido; a eliminação de detenções secretas; a proibição de prisões arbitrárias e cometidas por agentes não autorizados por lei; o acesso dos familiares aos presos; a proibição jurídica por meio da punição penal pelo cometimento do desaparecimento forçado de pessoas; a orientação em relação à responsabilidade individual e a obrigação de desobedecer em caso de mando para participação de alguma desaparição; a investigação de todas as denúncias de desaparecimento forçado; o julgamento dos responsáveis pelos desaparecimentos; a reparação às vítimas de desaparecimento e aos familiares; a ratificação dos instrumentos internacionais de direitos

${ }^{153}$ E/CN.4/1992/18, p. 9, para. 30 e 31.

${ }^{154}$ E/CN.4/1993/25, p. 13, paras. 50-1 
humanos e sua respectiva implementação; a responsabilidade dos Estados em intercederem em outros Estados que perpetuam o desaparecimento. ${ }^{155}$

Em 1993 o grupo de trabalho enviou cartas aos países e organizações não-governamentais, com o objetivo de identificar os obstáculos para implementação da Declaração adotada em 1992 em cada país. Para as organizações não-governamentais, haver conflitos armados internos seria o principal fator, somado a uma falta de vontade política para pôr fim à questão dos desaparecimentos, expressa pelas leis de anistia e pela inefetividade dos instrumentos de proteção judicial, como o habeas corpus. Ademais, apontaram a falta de legislação interna específica de tutela ao desaparecimento, e da falta de divulgação da Declaração dentre as instâncias de poder do governo, e para a sociedade em geral. ${ }^{156}$ Nos anos seguintes o grupo de trabalho seguiu coletando informações acerca da situação de desaparecimentos nos países, buscando incentivar a implementação da Declaração em âmbito interno. Especial atenção foi dada à questão na Ex-Iugoslávia, a partir também das considerações do relator independente Sr. Manfred Nowak ${ }^{157}$.

No ano de 1996 a Sub-Comissão para Prevenção da Discriminação e Proteção das Minorias deu início aos trabalhos preparatórios para redação de um projeto de Convenção sobre Desaparecimento Forçado ${ }^{158}$, sendo que em sua $35^{\text {a }}$. sessão o grupo de trabalho fez uma audiência pública com representantes de organizações não-governamentais para discutir o projeto, em particular a proposta de monitoramento do mecanismo. Assim, o grupo compreendeu que junto com a adoção da Convenção deveria ser criado um grupo para acompanhamento e monitoramento da implementação das determinações da Convenção. Dessa forma, o grupo foi chamado a participar da $2^{\mathrm{a}}$. reunião dos expertos para elaboração da Convenção, ocorrida em novembro de $1997 .{ }^{159}$

Em 27 de junho de 1997, em decorrência de diversos países começarem a indenizar pecuniariamente os familiares de desaparecidos, o grupo de trabalho decidiu enviar questões aos Estados que tinham mais de 20 casos de desaparecimento pendentes de solução, com o

\footnotetext{
${ }^{155}$ AMNESTY INTERNATIONAL. Desapariciones forzadas y homicídios políticos - La crisis de los derechos humanos em los noventa. Manual para la acción. Madrid: Editorial Amnistía Internacional - EDAI, 1994, pp. 291-3.

${ }^{156}$ E/CN.4/1994/26, pp. 22-3, para. 87.

${ }^{157}$ E/CN.4/1996/38, p. 17 , para. 59 .

${ }_{158}$ E/CN.4/1997/34, p. 11, para. 31

${ }^{159}$ E/CN.4/1998/43, p. 8, paras. 18-20.
} 
fim de ajudá-los a organizar suas compensações. As perguntas enviadas foram: qual a base jurídica para compensação; o que é necessário para presunção de morte, e se ela pode ser determinada mesmo contra a vontade da família; se o governo usou o método de exumação para identificar o desaparecido; se o governo indeniza os familiares das vítimas. Nesse sentido, o grupo visava a compreender como os países vinham tratando das questões de exumação e identificação dos corpos dos desaparecidos, bem como o modo como interpretavam a presunção de morte de pessoas desaparecidas, face às implicações que essas duas questões faziam emergir no que concerne às indenizações, mas especialmente à satisfação dos familiares dos desaparecidos. ${ }^{160}$

No ano de 1998, em razão do aniversário de cinqüenta anos da DUDH e dos cinco anos da Conferência de Viena, o grupo de trabalho teceu algumas considerações acerca do fenômeno do desaparecimento forçado de pessoas em seu $18^{\circ}$. Relatório. Lembrou que o desaparecimento surgiu na década de 1960 na América Latina sob regimes ditatoriais, e rapidamente se proliferou em outras regiões do mundo, destacando sua ocorrência no Iraque, Sri Lanka, e países da Ex-Iugoslávia, e em outros países sob situação de conflitos armados internos e tensões étnicas e religiosas. Constatou que grande parte dos casos sob sua análise advinha da América Latina, ocorridos na década de 1970, e o aumento do interesse dos países em saber das circunstâncias nessa década de 1990, por isso o grupo intensificou suas atividades no sentido de mediar a relação entre os familiares dos desaparecidos e os governos, para encontrar soluções a esses antigos casos satisfatórias a todas as partes, a despeito das leis de anistia promulgadas nessa região, que impedia a apuração integral dos fatos ${ }^{161}$. Um método que considerou indispensável para solucionar os casos de desaparecimento dizia respeito às ações de exumação e identificação dos restos mortais localizados em valas comuns, iniciadas em 1990. Apontou também que a indenização pecuniária era somente uma forma de reparar as vítimas, na medida em que ela não substituiria outras formas de reparação de ordem moral e simbólica. Refletiu que uma das razões essenciais que permitiam a continuidade desse fenômeno no mundo era a impunidade dos autores de tal crime, bem como a falta de reforma das instituições políticas, penais e administrativas dos Estados, e o respeito às garantias judiciais. Por fim, o grupo chamou mais uma vez a atenção dos Estados para colaborarem com as atividades das Nações Unidas no sentido de clarificar os casos de desaparecimento

\footnotetext{
${ }^{160}$ E/CN.4/1998/43, p. 9, para. 23.

161 Relata que um bom exemplo disso era a Comissão sobre Mortos e Desaparecidos criada no Brasil em 1995, que visava a reconhecer essas vítimas e indenizar os familiares. E/CN.4/1998/43, p. 84, para. 413.
} 
forçado, pois este crime era desconhecido há trinta anos, e somente seria possível que desaparecesse da história tão rapidamente como apareceu, se houvesse vontade política dos governos em erradicar tal prática. ${ }^{162}$

Dando continuidade à elaboração de um projeto de Convenção, em 23 de abril de 2001, por meio da Resolução 2001/46, a Comissão de Direitos Humanos decidiu estabelecer um grupo de trabalho e nomear um experto independente para examinar o marco internacional existente em matéria penal e de direitos humanos, para a proteção de todas as pessoas contra o desaparecimento forçado, e deveria trabalhar em concerto com o grupo de trabalho sobre desaparecimento forçado de pessoas, sendo que um dos membros do grupo encarregado do projeto era o Sr. Manfred Nowak, que tinha larga experiência na temática em questão. ${ }^{163}$

No ano de 2005 o grupo de trabalho recebeu um alto número de denúncias de desaparecimentos, e expressou sua preocupação pela situação desse crime no mundo, inclusive pela demora em clarificar os casos antigos ${ }^{164}$. Destacou a situação das crianças, além da vulnerabilidade das testemunhas, dos familiares, dos defensores de direitos humanos, determinando que os Estados dessem proteção a tais grupos. Reafirmou o caráter mundial do desaparecimento forçado, que nesse momento acontecia em países onde havia conflitos internos. ${ }^{165}$ Expressou em seguida sua preocupação com o fato de que em diversos países não existiam organizações não-governamentais estruturadas para trabalhar com a questão do desaparecimento. ${ }^{166}$

O último relatório acerca das atividades do grupo de trabalho, analisado por esta dissertação, ressalta a preocupação no que concerne às medidas adotadas para lutar contra o terrorismo, no sentido de restrição de liberdades individuais e garantias judiciais, típica de contextos ditatoriais. Aponta que em determinadas circunstâncias o desaparecimento forçado de pessoas constitui crime contra a humanidade, e reafirma a necessidade de julgar os perpetradores. Adicionalmente, o grupo aponta a necessidade de os Estados repararem as vítimas, e de efetivarem o direito à verdade, com o fim de promover a reconciliação de suas sociedades, e garantir a não repetição de graves violações de direitos humanos, especialmente os

${ }^{162}$ E/CN.4/1998/43, pp. 82-6, paras. 408-19.

${ }^{163} \mathrm{E} / \mathrm{CN} .4 / 2002 / 79$, p. 14 , paras. 24-5.

${ }^{164} \mathrm{~A} / \mathrm{HRC} / 4 / 41$, p. 11 , paras. 24-7.

${ }_{165}^{165}$ E/CN.4/2006/56, pp. 6-7, paras. 4-8.

${ }^{166} \mathrm{~A} / \mathrm{HRC} / 4 / 41$, p. 11, para. 28. 
desaparecimentos forçados. Nesse sentido, o grupo de trabalho destacou os esforços de 79 Estados para a adoção da Convenção de 2006, e afirmou a necessidade deste importante tratado para pôr fim aos desaparecimentos no mundo. ${ }^{167}$

Fazer a análise da atuação do grupo de trabalho da ONU, desde o seu estabelecimento em 1980, mostrou-se pertinente, pois foi possível verificar o histórico do desenvolvimento da construção fática e normativa do fenômeno do desaparecimento forçado de pessoas a partir de um órgão comprometido com as vítimas e com a promoção dos direitos humanos no mundo. Dessa forma, foi possível observar o histórico das questões atinentes ao desaparecimento, que informaram a elaboração dos instrumentos normativos. Por exemplo, durante a década de 1980 a comunidade internacional tratava de compreender e definir juridicamente o desaparecimento forçado, grave violação de direitos humanos, com natureza de crime contra a humanidade - como expresso na Declaração de 1992 e Convenção Interamericana de 1994. $\mathrm{Na}$ década seguinte, questões adicionais passaram a ganhar relevo, tais como a impunidade, as leis de anistia, a localização de valas comuns com restos mortais, além de contextos diversos daquele em que se originou o fenômeno, como situações de conflitos armados internos. No fim dos anos 1990 e início dos 2000 outros assuntos ganham destaque, como a necessidade de reparação às vítimas e o direito à verdade.

Em suma, esses desdobramentos do complexo fenômeno do desaparecimento forçado foram sendo percebidos ao longo dos anos e das atividades do grupo de trabalho da ONU, das organizações não-governamentais, dos familiares das vítimas, da comunidade internacional em geral, dos próprios Estados, haja vista a ocorrência dessa grave violação de direitos humanos ter se originado no passado recente. E, assim como o desaparecimento forçado lançou-se como desafio para a humanidade, as ações relativas à erradicação e à minimização de suas conseqüências não estão previstas, e continuam a ser construídas.

${ }^{167}$ A/HRC/10/9, pp. 97-9, paras. 448-60. 


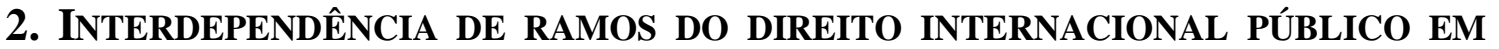 RELAÇÃO AO DESAPARECIMENTO FORÇADO DE PESSOAS}

Ao se tratar da normativa internacional do desaparecimento forçado de pessoas, conforme disposto no primeiro capítulo desta dissertação, tem-se o direito internacional humanitário, o direito internacional dos direitos humanos e o direito Internacional Penal como os ramos do direito internacional público desenvolvidos a partir e para garantir a dignidade humana, e conseqüentemente se ocupando da constituição de uma base de direito internacional a fim de tutelar a complexidade do fenômeno do desaparecimento.

Desse modo, este capítulo tem por fim discorrer acerca da interdependência dos ramos direito internacional humanitário, direito internacional dos direitos humanos e direito internacional penal, no que se refere ao tratamento do desaparecimento forçado de pessoas. Enquanto o primeiro traça definições à proteção das pessoas contra o desaparecimento forçado em caso de conflitos, e estabelece regras para lidar com as situações, especialmente oferecendo amparo às famílias, o segundo ramo do direito internacional define as diretrizes para proteção das pessoas contra o desaparecimento, determina a responsabilidade dos Estados e outros sujeitos da comunidade internacional para prevenção, investigação e reparação a essa grave violação de direitos humanos. O direito internacional penal, por sua vez, concebe o desaparecimento forçado de pessoas como crime contra a humanidade, inaugurando uma vertente de proteção dos valores mínimos comuns à humanidade, e estabelecendo a responsabilidade penal individual.

Nessa perspectiva, a partir do desaparecimento forçado de pessoas, será compreendido como esses ramos do direito Internacional Público atuam de maneira interdependente frente ao tema em análise, por meio da construção de sua base normativa referente à tutela dos interesses das vítimas e da humanidade como um todo.

\subsection{O direito internacional humanitário e o desaparecimento de pessoas}


O direito internacional público - classicamente direito das gentes - tem suas bases na regulação do direito da guerra, que a partir do século XVI confundia-se com o direito da guerra e da paz. Desta feita, o direito internacional humanitário ${ }^{168}$, direito dos conflitos armados ou direito da guerra é ramo do direito internacional público que, durante conflitos armados, visa a proteger as pessoas que não participam ou deixaram de participar das hostilidades, e a limitar os meios e métodos aplicados na guerra. Tem origem convencional ou consuetudinária, e compreende dois braços distintos em seu processo de positivação que se inicia no século XIX, o Direito de Genebra e o Direito de Haia, que foram unificados com o chamado Direito de Nova Iorque. ${ }^{169}$ Tem como princípios a humanidade, a necessidade - para limitar a ação -, a proporcionalidade, a distinção entre combatentes e civis, a proibição de causar danos e sofrimentos desnecessários, e a independência entre o ius in bello e o ius ad bellum.

"Em 1859 Henry Dunant, um cidadão suíço, de passagem pela zona de hostilidades da Batalha de Solferino, envolvendo a Itália, França e Áustria, fica indignado com as condições dos feridos de guerra: 40.000 vítimas, deixadas sem socorro na zona de conflito."170 A partir das sugestões em seu relato intitulado "Uma lembrança de Solferino", publicado em 1862, iniciou-se um movimento para criação de instituições de socorro aos militares feridos em batalha, além da convocação de uma conferência entre os Estados com o fim de discutir as normas que iriam reger o funcionamento dessas instituições. No ano seguinte, em 1863, Henry Dunant, Guillaume-Henri Dufour, Gustave Moynier, Louis Appia e Théodore Maunoir, todos suíços, fundaram o Comitê Internacional da Cruz Vermelha - que veio a assumir esse nome em 1980, anteriormente chamado Comitê Internacional de socorro aos militares feridos -, dando início ao Movimento Internacional da Cruz Vermelha e do Crescente Vermelho ${ }^{171}$. Em 1864 foi elaborada a primeira Convenção de Genebra, a

\footnotetext{
168 Para estudo mais aprofundado acerca do Direito internacional humanitário verificar: SWINARSKI, Christophe. Introdução ao direito internacional humanitário. Brasília: Comitê Internacional da Cruz Vermelha e Instituto Interamericano de Direitos Humanos, 1993.

${ }^{169}$ COMITÊ INTERNACIONAL DA CRUZ VERMELHA, Droit International Humanitaire. Réponses à vos questions. Genebra: CICR, $2^{\text {a }}$. ed., 2004, pp. 4-5.

${ }^{170}$ PERRONE-MOISÉS, Cláudia. Imunidades de chefes de Estado e crimes internacionais. Tese de Livre Docência apresentada na Faculdade de Direito da USP, 2009, pp. 17-8.

${ }^{171} \mathrm{O}$ Movimento Internacional da Cruz Vermelha e do Crescente Vermelho é formado pelo Comitê Internacional da Cruz Vermelha, as Sociedades Nacionais da Cruz Vermelha e do Crescente Vermelho, e a Liga de Sociedades da Cruz Vermelha e do Crescente Vermelho.
} 
Convenção da Cruz Vermelha, primeira iniciativa de positivação do Direito internacional humanitário, que tinha por fim melhorar as condições dos militares feridos. ${ }^{172}$

Durante as Conferências de Paz, ocorridas em 1899 e 1907, foram adotadas as Convenções de Haia, destinadas a regulamentar os meios e métodos utilizados nas hostilidades, de modo que a partir de então os Estados não seriam mais livres para escolher o modo como praticariam as hostilidades, mas que obedeceriam a certas normas, com o fim de não causar sofrimento desnecessário. Assim, com o nascimento do Direito de Genebra e do Direito de Haia, começou-se a normativizar o ius in bello, tendo destaque o Protocolo de Genebra de 1925, que proibia a utilização de determinadas armas e gases durante a guerra, as duas Convenções de Genebra de 1929, cujos objetos eram a revisão da Convenção de Genebra de 1906 - que revisou a de 1884 - e o tratamento aos prisioneiros de guerra. Em 1945 acontece mudança significativa no espectro do direito internacional humanitário, com a Carta da ONU, que passa a proibir o ius ad bellum. ${ }^{173}$

Contudo, a despeito da determinação do referido tratado, o direito internacional humanitário seguiu desenvolvendo sua normativa, adotando, em 1949, as quatro Convenções de Genebra, com o fim de proteger os feridos e enfermos em batalha, os náufragos, os prisioneiros de guerra e finalmente os civis. Em 1977 foram adotados os dois Protocolos Adicionais às Convenções de Genebra, reforçando a proteção das vítimas nos conflitos armados internacionais e não internacionais. Dessa maneira, esses dois instrumentos compõem os principais documentos do direito internacional humanitário. Sua positivação tem seqüência em 1980 com a Convenção quadro sobre Certas Armas Convencionais, a Convenção das Armas Químicas de 1993, a Convenção sobre a proibição do emprego, armazenamento, produção e transferência de minas anti-pessoais e sua destruição de 1997, o Estatuto de Roma que define os crimes de guerra e os estabelece sob jurisdição do TPI, o Protocolo Facultativo sobre crianças e conflito armado de $2000 .{ }^{174}$

Dessa forma, os princípios e normas de direito internacional humanitário são aplicados em caso de conflito armado internacional, e visam a proteger os indivíduos que não participam do

${ }^{172}$ PERRONE-MOISÉS, Cláudia. Imunidades de chefes de Estado e crimes internacionais. Tese de Livre Docência apresentada na Faculdade de Direito da USP, 2009, p. 18.

${ }^{173}$ Idem, pp. 18-9

${ }^{174}$ COMITÊ INTERNACIONAL DA CRUZ VERMELHA, Droit International Humanitaire. Réponses à vos questions. Genebra: CICR, 2a ${ }^{\text {a }}$ ed., 2004, pp. 10-1 
combate ou não estão mais em combate, como os militares enfermos, náufragos, prisioneiros de guerra e população civil, como os refugiados e estrangeiros, os civis em territórios ocupados, os presos, os agentes de saúde, de organizações de proteção civil etc. Também são aplicados em caso de conflito armado não-internacional, de modo que o direito internacional humanitário protege as forças armadas regulares ou não, que tomam parte no conflito, e os indivíduos que não participam ativamente nas hostilidades, como por exemplo, os combatentes enfermos, os presos em decorrência do conflito, a população civil, os agentes de saúde e religiosos. ${ }^{175}$

No que diz respeito à tutela do direito internacional humanitário em relação aos desaparecimentos $^{176}$, sua base está nas Convenções de Genebra de 1949 e nos Protocolos Adicionais de 1977, que determinam, basicamente, o direito dos familiares de saberem a sorte de seus parentes ${ }^{177}$. Da mesma maneira, as partes beligerantes têm a obrigação de buscar as pessoas cujo desaparecimento tiver sido apontado pela parte adversa ${ }^{178}$. Se a pessoa está desaparecida em razão de interrupção dos serviços de comunicação, o contato com os familiares deve ser restaurado tão logo seja possível, a fim de unificar novamente a família ${ }^{179}$. Caso a pessoa esteja desaparecida em virtude de detenção ou hospitalização pela parte contrária, as autoridades devem imediatamente informar sua captura ou hospitalização ${ }^{180}$, e permitir ao detento que se corresponda com a família ${ }^{181}$. Ademais, as autoridades que detém prisioneiros são obrigadas a responder inquirições acerca das pessoas protegidas ${ }^{182}$.

A situação é mais delicada quando a pessoa desaparecida encontra-se morta, pois as partes em conflito têm responsabilidade em relação a essas pessoas, devendo trocar informações sobre o lugar exato onde se encontram as sepulturas e assinalá-las, assim como proporcionar os dados

\footnotetext{
${ }^{175}$ Idem, pp. 16-7

${ }^{176}$ Missing persons are either dead or alive. If they are alive, they are either detained by the enemy or free, but separated from their families by front lines or borders. In both cases they are entitled to the protection offered by international humanitarian law to the category (civilians, prisoners of war, wounded and sick etc) to which they belong. In addition international humanitarian law ensures that most of them do not remain considered as missing. SASSÒLI, Marco e TOUGAS, Marie-Louise. The ICRC and the missing. In International Review of the Red Cross. Humanitarian debate: law, policy, action. Vol. 84, 2002, p. 730.

${ }^{177}$ Protocolo Adicional I, art. 32.

${ }^{178}$ Protocolo Adicional I, art. 33.

$1794^{\mathrm{a}}$. Convenção de Genebra, arts. 25 e 26.

$1801^{\text {a }}$. Convenção de Genebra, art. 16; $2^{a}$. Convenção de Genebra, art. 19; $3^{\mathrm{a}}$. Convenção de Genebra, arts. 70, 122 e 123; 4 ${ }^{\text {a }}$. Convenção de Genebra, arts. 106, 136 e 140; Protocolo Adicional I, art. 33 (2).

${ }^{181} 3^{\text {a }}$. Convenção de Genebra, art. 71 e $4^{\text {a }}$. Convenção, art. 107.

$1823^{\mathrm{a}}$. Convenção de Genebra, arts. 122 (7); $4^{\mathrm{a}}$. Convenção de Genebra, art. 137 (1)
} 
das pessoas sepultadas ${ }^{183}$. Por conseguinte, os beligerantes devem coletar todas as informações que ajudam a identificar a pessoa morta, garantindo acesso dos familiares ao local de sepultamento de seu parente, podendo reaver seus restos mortais, a partir do acordo das partes beligerantes ${ }^{184}$ - contudo, os familiares geralmente recebem os restos mortais de seu parente somente após o fim do conflito.

O Comitê Internacional da Cruz Vermelha trabalha no sentido de combater os desaparecimentos forçados, mediante determinadas ações, tais como visitando lugares de detenção e registrando os nomes dos prisioneiros; mantendo uma Agência Central de Busca para localizar as pessoas que tenham desaparecido, ou aquelas cujos familiares não tenham recebido notícia; promovendo, junto com as Sociedades Nacionais da Cruz Vermelha e do Crescente Vermelho, a disseminação dos princípios e leis aplicadas à guerra ${ }^{185}$. No entanto, apesar das ações destinadas ao tratamento dos desaparecidos, se as regras especificadas pelo direito internacional humanitário fossem devidamente aplicadas em situação de conflitos armados, internos ou internacionais, certamente haveria uma redução do número de pessoas desaparecidas nestas circunstâncias ${ }^{186}$.

\subsection{O direito internacional dos direitos humanos $e$ o desaparecimento forçado ou involuntário de pessoas}

$\mathrm{O}$ direito internacional clássico, como intitulado até o final da $2^{\mathrm{a}}$. Guerra Mundial, era o direito que regulava as relações entre os Estados da sociedade internacional. Até então, os Estados eram os únicos sujeitos de direito, e este direito servia para garantir sua coexistência, pois afirmava sua soberania, e pretendia organizar a interdependência necessária, preservando a independência dos Estados. O início de internacionalização dos direitos humanos remonta à criação da Liga das Nações e da Organização Internacional do Trabalho, nas quais a projeção dos direitos humanos tinha objetivos pontuais e diversos - respectivamente a proteção dos direitos fundamentais em situação de conflito armado, bem como a manutenção da paz e segurança internacional; e o estabelecimento de condições de trabalho mínimas. A proteção

$1831^{\text {a }}$. Convenção, art. 17; Protocolo Adicional I, art. 34

${ }^{184}$ Protocolo I, art. 34 (2), (4).

185 ANISTIA INTERNACIONAL. Desapariciones forzadas y homicídios políticos: La crise de los derechos humanos em los noventa. Madri: EDAI, 1994, p. 267.

${ }^{186}$ SASSÒLI, Marco e TOUGAS, Marie-Louise. The ICRC and the missing. In International Review of the Red Cross. Humanitarian debate: law, policy, action. Vol. 84, 2002, p. 731. 
dos direitos humanos por estas organizações gerou mudanças no direito internacional, pois rompeu com a noção de soberania absoluta dos Estados, ao admitir intervenções no plano nacional em defesa dos direitos humanos.

Todavia, foi apenas com a criação da ONU, por meio da Carta da ONU, em 1945, que as pessoas e organizações foram admitidas sujeitos de direito para o direito internacional. Neste momento, a sociedade de Estados soberanos começou a dar espaço para uma comunidade internacional, cujos membros passaram a se relacionar de maneira mais comunitária e de equidade, em prol da defesa do valor-fonte da dignidade da pessoa humana. Assim, o direito internacional dos direitos humanos, como atualmente é conhecido, nasceu no século XX, com o fim da $2^{\text {a }}$ Guerra Mundial.

A ascensão da pessoa à categoria de sujeito deveu-se às atrocidades cometidas durante o regime nazista. Até então, embora os direitos do homem fossem inalienáveis e irredutíveis, a única autoridade que os estabelecia eram os Estados, pois não havia nenhuma outra que os garantisse. Na política totalitária de Hitler, a desnacionalização tornou-se uma arma poderosa, pois era a forma que as pessoas perdiam seus direitos de homem ${ }^{187}$, e sem eles poderiam simplesmente desaparecer. Esse momento da história produziu pessoas descartáveis e supérfluas, que legitimou o genocídio e outras formas de aniquilação, por isso os padrões éticos, jurídicos e políticos da humanidade foram revistos, e com isso a formação de uma nova ordem internacional que protegesse as pessoas, independentemente de sua nacionalidade ou relação com um Estado, fez-se necessária ${ }^{188}$.

Nessa nova perspectiva, a comunidade internacional passou a criar diversos acordos, na forma de normativa internacional, para que os direitos humanos fossem respeitados, tendo como princípio basilar a dignidade da pessoa humana. Nesse sentido, Andorno trata da noção de dignidade humana:

Dignidade humana é o centro do núcleo duro de direitos humanos; direitos humanos são justificados por se referirem à dignidade humana; seres humanos têm direitos porque eles são dignos de respeito. Se quisermos expressar a dignidade humana usando a terminologia dos direitos, o máximo que podemos dizer é que a dignidade

${ }^{187}$ ARENDT, Hannah. Origens do Totalitarismo. São Paulo: Companhia das Letras, 1989, pp. 324-325.

${ }^{188}$ LAFER, Celso. Reconstrução dos Direitos Humanos. São Paulo: Companhia das Letras, 2001, p. 167. 
humana é o 'o direito a ter direitos', ou, em outras palavras, 'o direito a ser reconhecido como uma pessoa'. 189

O processo de positivação dos direitos humanos no direito internacional iniciou-se no período imediato pós $2^{\text {a }}$. Guerra Mundial, com o escopo de afastar a prepotência do poder tal como exercido pelo regime nazista. Assim, a adoção da DUDH em 1948 inaugurou uma nova etapa no tema dos direitos humanos, servindo de parâmetro de inspiração e orientação no processo de desenvolvimento de toda comunidade internacional, visto que estabelece direitos mínimos a serem obedecidos por toda a comunidade internacional em prol da humanidade.

Nesse sentido, a DUDH constitui expressão dos valores universais da humanidade, eleita e elaborada de maneira consensual pelos Estados, portanto representa a vontade de todos em "incrustar o respeito da dignidade da pessoa humana na consciência da comunidade universal e evitar o ressurgimento da idéia e da prática da descartabilidade do homem, da mulher e da criança" ${ }^{190}$. Embora a DUDH não seja formalmente um tratado internacional, compreende-se que ela é vinculante e obrigatória aos Estados, e, de acordo com decisão da Corte Internacional de Justiça, tem o mesmo status jurídico que a Carta da ONU. Na atualidade, seus dispositivos constituem normas consuetudinárias de direito internacional, e formam o corpo do ius cogens.

Normas de ius cogens são aquelas imperativas para o direito internacional, ou seja, todas são obrigatórias na medida em que constituem consenso entre os Estados. A despeito de não existir hierarquia entre as fontes de direito internacional, existem entre as normas, sendo que as de ius cogens estão acima de todas as outras, pois não admitem derrogação. De acordo com Virally as normas são inderrogáveis, pois não dizem respeito ao interesse individual dos Estados - normas de direitos humanos -, e porque tem como base a proteção daqueles menos poderosos. Assim, “o ius cogens limita a autonomia dos Estados e torna a soberania absoluta

${ }^{189}$ ANDORNO, Roberto. The paradoxical notion of human dignity. In Rivista Internazionali di filosofia Del diritto, 2001, p. 159. Human dignity is the center core of human rights; human rights are justified by reference to human dignity; human beings have rights because they are worthy of respect. If we want to express human dignity using the terminology of rights, the most we can say is that human dignity is the 'right to have rights', or in other words, 'the right to be recognized as a person'.

${ }^{190}$ ALMEIDA, Guilherme Assis de. A Declaração Universal dos Direitos Humanos de 1948: matriz do Direito internacional dos direitos humanos. In: ALMEIDA, Guilherme Assis de e MOISÉS, Cláudia Perrone (org.). Direito internacional dos direitos humanos. São Paulo: Atlas, 2002, pp. 13-4. 
uma noção abstrata. A soberania absoluta vai de encontro, precisamente, aos interesses da comunidade internacional em seu conjunto, que o ius cogens pretende defender."191

A comunidade internacional gera a existência de determinada ordem pública; e, por mais que tenham fundamento ético, as normas de ius cogens não se constituem em direito natural; o “ius cogens evolui em função das transformações sócio-históricas da sociedade internacional e constitui o direito positivo de determinada sociedades em determinado momento." ${ }^{\prime 192}$ Estas normas contém valores compartilhados pela comunidade internacional, e cria instituições guardiãs e promotoras desses valores, de modo que "a afirmação da responsabilidade penal individual em relação a crimes internacionais e o reconhecimento de obrigações em relação à comunidade internacional, (obrigações erga omnes) vêm transformando o direito internacional, e em decorrência, o conceito clássico de soberania."193

Contudo, a despeito de a DUDH ter esse poder basilar na construção jurídica internacional, os direitos humanos não são protegidos apenas com sua proclamação, sendo necessário estabelecer mecanismos para sua proteção. Nesse sentido, a comunidade internacional passou a desdobrar os princípios contidos na DUDH em tratados internacionais, em que Bobbio ${ }^{194}$ nomeou de etapa de proliferação ou multiplicação dos direitos. Essa proliferação ocorreu de três formas, houve um aumento na quantidade de bens considerados merecedores de tutela; a titularidade de alguns direitos foi estendida a sujeitos diversos do homem; o homem passou a ser visto na concreticidade de cada um dos papéis que desempenha na sociedade. No primeiro processo, Bobbio ressalta a passagem dos direitos de liberdade para os direitos políticos e sociais, os quais requerem a intervenção direta do Estado. No segundo caso, a titularidade de direitos deixou de ser atribuída apenas ao ser humano individualmente, e passou a ser atribuída a outros sujeitos, família, minorias étnicas, humanidade etc. O terceiro refere-se à especificação de grupos, o homem deixou de ser considerado genericamente e passou a ser visto especificamente, baseado em critérios legítimos de diferenciação, como sexo, idade, condições físicas etc.

${ }^{191}$ PERRONE-MOISÉS, Cláudia. Imunidades de chefes de Estado e crimes internacionais. Tese de Livre Docência apresentada na Faculdade de Direito da USP, 2009, pp. 13-4.

${ }^{192}$ Idem, p. 15

${ }^{193}$ Idem, p. 16.

${ }^{194}$ BOBBIO, Norberto. A era dos direitos. Rio de Janeiro: Campus, 2004, p. 83. 
Nesse esteio, em 1966 a ONU adotou o Pacto de Direitos Civis e Políticos e o Pacto de Direitos Econômicos, Sociais e Culturais, desdobramentos da DUDH, que teve seus princípios reescritos em forma de lei, obrigando os Estados que os ratificassem a cumprir e garantir os direitos estabelecidos. Nesse bojo, os direitos humanos foram considerados indivisíveis, integrados e universais, sendo que todos os direitos civis, políticos, econômicos, sociais e culturais foram entendidos como interdependentes. Nesta lógica, a DUDH foi jurisdicionalizada mediante tratados internacionais, cuja função é a de regular e aplicar os direitos humanos internacionalmente reconhecidos e estabelecer um sistema de controle para assegurar sua implementação. A formação de um sistema internacional integrado por tratados internacionais reflete a consciência ética contemporânea compartilhada pelos Estados, visando à salvaguarda de parâmetros protetivos mínimos, o chamado 'mínimo ético irredutível $^{195}$. Assim, a DUDH somada aos dois Pactos de 1966 formam a Carta Internacional dos Direitos Humanos (International Bill of Rights), que inaugura o sistema global de âmbito geral de proteção dos direitos humanos.

Esta foi a primeira fase de proteção dos direitos humanos, marcada pela tônica da proteção geral da pessoa humana. Contudo, era insuficiente tratar o indivíduo de modo genérico, geral e abstrato, e percebeu-se a necessidade de conferir a determinados grupos uma proteção particular e especial, em virtude de sua vulnerabilidade. Nesse sentido de especificação do sujeito de direitos, aponta Piovesan:

O processo de internacionalização dos direitos humanos, conjugado com o processo de multiplicação desses direitos, resultou em um complexo sistema internacional de proteção, marcado pela coexistência do sistema geral e do sistema especial de proteção. [...] O sistema especial de proteção realça o processo de especificação do sujeito de direito, em que o sujeito de direito é visto em sua especificidade e concreticidade. Isto é, as Convenções que integram este sistema são endereçadas a determinados sujeitos de direito, ou seja, buscam a responder a determinada violação de direito. ${ }^{196}$

Assim, a ONU passou a criar, após a delimitação das regras gerais que servem para todos, um sistema específico de proteção aos direitos humanos, destinados a pessoas determinadas, ou em situações especiais. Por exemplo, as mulheres, crianças, têm um sistema específico de proteção, pois se considera que possuem necessidades especiais, além de estarem em grupos que historicamente têm direitos violados, por isso considerados vulneráveis.

195 PIOVESAN, Flávia. Direitos Humanos e o Direito Constitucional Internacional. São Paulo: Max Limonad, 2002, pp. 307-317.

196 Idem, pp. 201-2. 
O ápice do processo de positivação dos direitos humanos ocorreu em 1993 durante a II Conferência Mundial de Direitos Humanos. A Declaração de Viena é o documento mais abrangente sobre o tema dos direitos humanos adotado pela comunidade internacional. Dentre as grandes conquistas da Declaração pode-se citar a reafirmação da universalidade dos direitos humanos, o reconhecimento da legitimidade da preocupação internacional com a promoção e proteção dos direitos humanos, o reconhecimento do direito ao desenvolvimento e, o estabelecimento do princípio norteador do documento, a interdependência entre democracia, desenvolvimento e respeito aos direitos humanos. ${ }^{197}$

Em Viena, reafirmou-se que os direitos humanos devem receber o tratamento de tema global, superando a posição de que se tratava de assunto de competência exclusiva dos Estados, adquirindo o caráter de valores fundamentais, que pautam a atuação de todos os atores internacionais, incluindo as organizações internacionais, sendo todos co-responsáveis por sua promoção. No plano horizontal, houve a preocupação de incluir a temática dos direitos humanos em todas as atividades e programas dos organismos que compõem a ONU. No plano vertical, buscou-se ressaltar a importância de incorporação dos direitos humanos no plano interno e da adoção de medidas nacionais para implementar os instrumentos internacionais de proteção dos direitos humanos. ${ }^{198}$

Paralelamente ao sistema global de proteção aos direitos humanos, existem os sistemas regionais, que internacionalizam os direitos humanos no âmbito das regiões da Europa, América e África. Os sistemas global e regionais têm entre si uma relação de complementaridade. O sistema regional europeu estruturou-se a partir da Convenção Européia para a Proteção de Direitos Humanos e das Liberdades Fundamentais (1950) e da Carta Social Européia (1961). Ele serviu de modelo para a estruturação do sistema de proteção americano, que tem a Convenção Americana de Direitos Humanos (1969) como seu documento mais importante. O sistema regional africano completa o conjunto do sistema regional, e tem como documento referência a Carta Africana de Direito dos Povos (1981).

Nesse sentido, o sistema internacional global e regional de proteção dos direitos humanos caracteriza-se pela complementaridade e subsidiariedade, além de operarem na lógica da

197 ALVES, José Augusto Lindgren. Direitos Humanos como tema global. São Paulo: Perspectiva, 2003, pp. $137-8$.

${ }^{198}$ Idem. 
interação com os sistemas nacionais, de acordo com o valor da primazia da pessoa humana. Assim, o direito internacional dos direitos humanos aprimora e fortalece o grau de proteção dos direitos humanos nos países, jamais restringem ou delimitam. É possível identificar essa relação na construção jurídica da tutela ao desaparecimento forçado de pessoas, em que os sistemas da ONU e da OEA operaram de forma conjunta.

Nesse sentido, o movimento de internacionalização dos direitos humanos contribuiu para o processo de democratização do próprio cenário internacional, pois, além de outros sujeitos de direitos participarem da arena internacional, a abertura é também no sentido de que os Estados confluam para a proteção da máxima que é a dignidade humana. Além do mais, a sistemática internacional de proteção permite a tutela, supervisão e monitoramento de direitos por organismos internacionais. Bobbio ${ }^{199}$ classifica as atividades realizadas pelos organismos internacionais para a tutela dos direitos humanos em atividades de promoção, controle e garantia. As atividades de promoção têm um duplo objetivo, que são o de induzir os Estados a introduzir mecanismos específicos para a tutela dos direitos humanos em seus ordenamentos e, ao mesmo tempo, incentivar os Estados que já os introduziram a aprimorá-los. As atividades de controle referem-se ao conjunto de medidas que os organismos internacionais utilizam para verificar em que medida as convenções e recomendações foram implementadas pelos Estados. As atividades de garantia procuram estabelecer um mecanismo de tutela internacional autônomo, capaz de substituir ou suprir os mecanismos estatais.

Nesse sentido, o que se observa é uma abertura cada vez maior no âmbito internacional para a promoção e proteção dos direitos humanos, que permeiam o modo dos Estados relacionaremse e operarem em relação aos seus cidadãos, que já não estão mais ligados à sua nacionalidade para terem direitos, mas pertencem à categoria humanidade, que por serem humanos, dotados de dignidade, são cidadãos universais, e têm seus direitos garantidos em qualquer lugar do mundo. Como aponta Delmas-Marty,

A partir dos direitos do homem fica possível imaginar um 'direito dos direitos' que permitiria aproximar, e não unificar, os diferentes sistemas. Aproximá-los numa harmônica feita tanto da subordinação deles a uma ordem supranacional como da coordenação deles segundo princípios comuns. Como nuvens que, levadas por um mesmo sopro, se ordenassem aos poucos guardando seu ritmo próprio, suas formas próprias. $^{200}$

${ }^{199}$ BOBBIO, Norberto. A era dos direitos. Rio de Janeiro: Campus, 2004, pp. 58-9.

${ }^{200}$ DELMAS-MARTY, Mireille. Por um direito comum. São Paulo: Martins Fontes, 2004, p. 306. 
Apresentado brevemente os princípios do direito internacional dos direitos humanos, cumpre compreender como os instrumentos adotados neste âmbito para erradicar a prática do desaparecimento forçado de pessoas, tais quais a Declaração da ONU, a Convenção Interamericana e a Convenção da ONU têm sua efetividade a partir do prisma do Direito Internacional.

O processo de codificação da Declaração sobre Desaparecimento Forçado ou Involuntário de Pessoas em âmbito do sistema global da ONU e da Convenção Interamericana sobre Desaparecimento Forçado no sistema regional da OEA foi simultâneo, e seguramente uma serviu a outra, em momentos diferentes, no sentido de reforçá-las ${ }^{201}$. Os grupos de direitos humanos insistentemente afirmaram que para haver efetiva prevenção e punição aos casos de desaparecimento, a Declaração de 1992 e a Convenção de 1994 deveriam conter dois elementos, quais sejam, que o desaparecimento forçado deveria ser considerado crime contra a humanidade, e tivesse efeitos legais enquanto esta categoria de crime, como a proibição à anistia ou asilo político aos perpetradores, e que deveriam conter mecanismos efetivos para prevenir desaparecimentos, como formas efetivas de investigar o ocorrido com os desaparecidos, a punição aos responsáveis, a reparação às vítimas ${ }^{202}$. Graças à atuação das organizações não-governamentais, ambos os instrumentos asseguram suas principais reivindicações. Primeiro que a prática sistemática do desaparecimento constitui crime contra a humanidade. Segundo que contém mecanismos para prevenir, investigar e sancionar os perpetradores, assim como para reparar as vítimas. ${ }^{203}$

Dessa maneira, durante as décadas de 1970, 1980 e meados de 1990, diversas manifestações políticas e jurídicas ${ }^{204}$ manifestaram que a gravidade e características do desaparecimento forçado justificariam a categorização da grave violação de direitos humanos como crime contra a humanidade, sendo previsto, então, a competência repressiva universal, a inadmissibilidade de leis de anistia e a imprescritibilidade. Contudo, não havia nenhum

201 BRODY, Reed e GONZALEZ, Felipe. Nunca más: an analyses of international instruments on "disappearances". In: Human Rights Quaterly, vol. 19, n. 12, The Johns Hopkins University Press, 1997, p. 371.

${ }^{202}$ Idem, p. 376.

${ }^{203}$ Idem, p. 403.

${ }^{204}$ Sentenças da Corte Interamericana de Direitos Humanos, Assembléia Geral da OEA, Assembléia Parlamentar do Conselho da Europa. 
instrumento até o Estatuto de Roma que assim o definisse, apesar de a Declaração definir que o desaparecimento "tem natureza de crime contra a humanidade"205.

Em relação à anistia e impunidade, a Declaração, a partir da manifestação da Comissão Interamericana de Direitos Humanos acerca de as leis de anistia da Argentina e Uruguai violarem a Convenção Americana de Direitos Humanos em razão dos abusos e graves violações de direitos humanos, prevê que os perpetradores de desaparecimento forçado não devem se beneficiar de anistia. Entretanto, a Convenção Interamericana não trata dessa questão, e há interpretação de que, como ela determina o julgamento dos perpetradores, seria redundante falar em proibição de anistia. ${ }^{206} \mathrm{Na}$ mesma perspectiva de tratamento do desaparecimento forçado como grave violação de direitos humanos, que se apóia nos princípios de direito internacional penal, direta ou indiretamente expressos pela Declaração e Convenção, a questão da obediência devida como escusa para a prática do desaparecimento não se configura legítima, e as pessoas que recebem tais ordens superiores têm o dever de desobedecer. $^{207}$

Na Convenção sobre a não aplicabilidade de limitações estatutárias para crimes de guerra e crimes contra a humanidade há a previsão de que esses crimes não são passíveis de prescrição, pois, devido a sua gravidade, o tempo não pode ser um óbice a sua prevenção e punição. Não obstante, os países onde o desaparecimento forçado ocorre, não têm um sistema de justiça adequado para conduzir tais investigações, e geralmente a apuração dos fatos só é possível quando há mudança de regime político. Contudo, apesar dessa compreensão, na preparação de ambos os instrumentos os Estados ficaram resignados em adotar a completa imprescritibilidade, de modo que consideraram os atos constitutivos do desaparecimento como continuado até que a situação se clarifique. ${ }^{208}$ Ambos os instrumentos também prevêem que o desaparecimento deve ser julgado em tribunais competentes, e não militares, assim como não admitem privilégios, imunidades, ou exceções aos perpetradores. ${ }^{209}$ Em relação aos países oferecerem asilo político aos perpetradores do desaparecimento, a Declaração é

\footnotetext{
${ }^{205}$ The systematic practice of such acts is of the nature of a crime against humanity. Preâmbulo da Declaração sobre Desaparecimento Forçado ou Involuntário de Pessoas.

206 BRODY, Reed e GONZALEZ, Felipe. Nunca más: an analyses of international instruments on “disappearances". In: Human Rights Quaterly, vol. 19, n. 12, The Johns Hopkins University Press, 1997, p. 3856.

${ }^{207}$ Idem, pp. 386-388.

${ }^{208}$ Idem, pp. 388-90.

${ }^{209}$ Idem, p. 393.
} 
ambígua, ao dizer que o fato de alguém ter participado no cometimento de desaparecimentos deve ser levado em conta quando da concessão ou não de asilo, enquanto a Convenção não faz menção a essa possibilidade. ${ }^{210}$

Quanto ao dever que tem o Estado de investigar, prevenir e punir o desaparecimento forçado ambos os instrumentos determinam essa responsabilidade dos Estados, que devem atuar no sentido de cooperarem entre si para erradicar tal prática, por meio de reformas legislativas, administrativas, judiciárias. E, se as ações dos Estados não forem suficientes para atingir tais objetivos, eles devem responder perante a comunidade internacional. Além disso, os documentos determinam que os Estados incorporem em suas legislações internas a provisão do desaparecimento como crime, e ofereçam alguma diminuição de pena àqueles que colaborarem para localizar os desaparecidos. ${ }^{211}$ Em relação à reparação às vítimas e familiares, a Declaração é clara no sentido do dever do Estado restituir integralmente o dano, enquanto a Convenção não menciona em seu texto essa questão, embora nos casos julgados pela Corte Interamericana seja determinada a reparação, pois compreende que os Estados têm o dever de compensar as vítimas de violações de direitos humanos. ${ }^{212}$

A outra razão pela qual os grupos de direitos humanos pressionaram as instâncias internacionais para a adoção de instrumentos era a criação de instrumentos efetivos para prevenir e investigar os desaparecimentos. Tanto na Declaração quanto na Convenção há a estipulação de que o habeas corpus é remédio preciso para localizar os desaparecidos, bem como saber suas condições de privação de liberdade, e identificar os agentes responsáveis por sua detenção. Tanto em âmbito da ONU quanto da OEA, há menções de que a suspensão desse tipo de garantia judicial não deve ser tolerada, em situações de estado de exceção, emergência ou guerra. Na mesma perspectiva, os dois documentos determinam que os prisioneiros devem ser levados a lugares oficiais, e serem apresentados a autoridades judiciais - ou seja, o cumprimento do devido processo legal deve ser efetivo. Além disso, compreendem que constitui forma eficaz de prevenir os desaparecimentos a rápida localização

\footnotetext{
${ }^{210}$ Idem, p. 395.

211 BRODY, Reed e GONZALEZ, Felipe. Nunca más: an analyses of international instruments on “disappearances". In: Human Rights Quaterly, vol. 19, n. 12, The Johns Hopkins University Press, 1997, p. 3834. ${ }^{212}$ Idem, p. 394.
} 
do paradeiro das pessoas detidas, por isso os Estados têm a obrigação de organizarem e oferecerem as informações e os locais de detenção. ${ }^{213}$

A Convenção sobre Desaparecimento Forçado ou Involuntário, por sua vez, adotada em 2006 no âmbito da ONU, conta com 8 ratificações, sendo necessário o número de 20 para entrar em vigor $^{214}$. Em seguida a isso, os Estados signatários deverão estabelecer em suas legislações nacionais os instrumentos legais e políticos para aplicar o tratado com o fim de erradicar a prática de desaparecimento internamente. Este tratado nasce na perspectiva de que o cometimento desse crime ainda é recorrente em diversas partes do mundo, a despeito de ter se originado na década de 1960 no seio da America Latina.

Dessa maneira, o direito internacional dos direitos humanos tanto em âmbito global como regional tem formado uma gama protetiva em relação ao desaparecimento forçado de pessoas no sentido de erradicação de tal prática, de forma a pressionar os Estados a assumirem essa obrigação internacional. "Sem tal vinculação entre responsabilidade internacional do Estado e os direitos humanos estaremos a um passo de afirmar o caráter de mero conselho ou exortação moral da proteção internacional dos direitos humanos" ${ }^{215}$. Não é demais ressaltar, contudo, que toda violação do Estado aos direitos humanos reconhecidos, incluída a prática do desaparecimento forçado, constitui ilícito internacional, e por essa razão pode ser internacionalmente responsabilizado. ${ }^{216} \mathrm{O}$ que se observa, contudo, é uma articulação entre o direito internacional dos direitos humanos e direito Internacional Penal cada vez mais próxima e coerente no que diz respeito à tutela de direitos humanos, formando, assim, uma cultura universal de que alguns atos e violações não podem mais ser tolerados pela humanidade.

\section{3. $O$ direito internacional penal e o desaparecimento forçado de pessoas}

\footnotetext{
${ }^{213}$ Idem, pp. 396-9.

${ }^{214}$ Status de ratificação em 04 de março de 2010. Disponível em http://treaties.un.org/Pages/ViewDetails.aspx?src=TREATY\&mtdsg_no=IV-16\&chapter=4\&lang=en

${ }^{215}$ RAMOS, André de Carvalho. Processo internacional de direitos humanos: análise dos sistemas de apuração de violações de direitos humanos e implementação das decisões no Brasil. Rio de Janeiro: Renovar, 2002, p. 10.

${ }^{216}$ ROJAS, Manuel Hinojo. Al hilo de la Declaración de 1992 de La Asamblea General de Naciones Unidas sobre la protección de todas las personas contra lãs desapariciones forzadas. In Anuario de Derecho Internacional, Universidad de Navarra, Pamplona, 1996, p. 503.
} 
Como conseqüência da ascensão da pessoa à categoria de sujeito, para o Direito Internacional, também se atualizou a mudança da perspectiva da responsabilidade internacional, que é a imputação de um fato a um sujeito que cometeu um ato ilícito. Na concepção clássica o Estado era o único que tinha a obrigação de reparar os danos causados por uma violação. É a partir do estabelecimento do Tribunal de Nuremberg, em 1945, quando pela primeira vez aparece a imputação de responsabilidade individual face ao direito internacional ${ }^{217}$. Dessa forma, além do desenvolvimento do direito internacional dos direitos humanos, pós Segunda Guerra, iniciou-se o desenvolvimento do direito internacional penal, dando origem a uma responsabilização dos indivíduos culpados de cometer graves violações de direitos humanos e de direito internacional humanitário. Nasceu a idéia de "crimes internacionais de direitos humanos" ${ }^{218}$ que diz respeito àqueles cometidos pelos indivíduos e que gera responsabilidade penal internacional. Nesse sentido, o crime constitui o fator da responsabilidade penal, pois se seu autor é capaz de cometê-lo, também é capaz de responder penalmente. Se a responsabilidade internacional tinha uma função inicial de reparação dos danos, a função repressiva da responsabilidade penal internacional se exerce progressivamente, e consiste na proteção dos valores eleitos pela comunidade internacional.

O direito internacional penal constitui-se paralelamente ao direito internacional dos direitos humanos, pois se baseia em valores comuns partilhados pela comunidade internacional. Assim, o surgimento de uma jurisdição penal e internacional evidencia um alto grau do universal normativo $^{219}$, na medida em que apresenta a punição como resposta aos crimes cometidos. "O direito internacional penal protege, de acordo com a tradição de Nuremberg, interesses fundamentais, bens supremos, como a paz e a dignidade do ser humano."220 Nesse mesmo sentido, "as normas que proíbem os crimes do núcleo duro do direito internacional penal pertencem ao ius cogens e constituem obrigações erga omnes."221

\footnotetext{
217 Antes do julgamento dos crimes do nazismo pelo Tribunal de Nuremberg já havia tido uma iniciativa de imputação de responsabilidade penal internacional em seguida à Primeira Guerra Mundial, com a proposta de julgar o ex-imperador da Alemanha, Guilherme II, que não foi entregue pela Holanda com a justificativa de que os crimes cometidos por ele eram políticos, não passíveis de extradição. PERRONE-MOISÉS, Cláudia. Imunidades de chefes de Estado e crimes internacionais. Tese de Livre Docência apresentada na Faculdade de Direito da USP, 2009, p. 20.

${ }^{218}$ Idem, p. 10.

${ }^{219}$ DELMAS-MARTY, Mireille. Por um direito comum. São Paulo: Martins Fontes, 2004, p. 64.

${ }^{220}$ PERRONE-MOISÉS, Cláudia. Imunidades de chefes de Estado e crimes internacionais. Tese de Livre Docência apresentada na Faculdade de Direito da USP, 2009, p. 9.

${ }^{221}$ Idem, p. 14
} 
Pode-se, contudo, subdividir os crimes previstos pelo direito internacional penal em duas categorias, na primeira a que tutela bens supremos, tais quais a paz e a dignidade do ser humano. Constituem então os crimes contra a paz, os crimes de guerra, os crimes contra a humanidade, e o crime de genocídio ${ }^{222}$.

Geralmente o direito internacional considera crimes de direitos humanos a violação entendida como atrocidade por seu efeito corporal ou espiritual e sua gravidade em relação à pessoa humana. A Comissão de direito internacional da ONU apontou características ao crime de direitos humanos: a gravidade do comportamento que afeta os fundamentos da sociedade humana, podendo ser deduzida do caráter do ato (crueldade, monstruosidade, barbárie etc); o alcance de seus efeitos (massivos) e em algumas hipóteses, a intenção do autor (genocídio). ${ }^{223}$

Como segunda categoria dos crimes estão aqueles que se desdobram com o direito penal internacional, na medida em que tratam dos crimes contra a segurança dos Estados, tais quais o narcotráfico, o terrorismo e a lavagem de dinheiro. A partir de uma concepção mais atual e ampliada, estes crimes também colocam em risco a ordem e a paz mundiais, por isso deveriam ser tratados com os crimes internacionais instituídos em Nuremberg. ${ }^{224}$

O direito internacional penal, dessa maneira, desenvolveu-se a partir do Acordo de Londres, que estabeleceu o Tribunal de Nuremberg e definiu os crimes de sua competência, que seriam julgados no pós Segunda Guerra. Em seguida, em 1946, os Estados aliados aprovaram a carta que criou o Tribunal Internacional Militar para processar os crimes de guerra cometidos pelos japoneses. A ONU, em 1997, adota a Convenção para Prevenção e Punição do Crime de Genocídio, e na mesma Resolução a Assembléia Geral convoca a Comissão de Direito Internacional para estudar a possibilidade de criação de um órgão judicial internacional para julgar pessoas que cometessem genocídio. Durante 1949 a 1954 a Comissão desenvolveu uma série de projetos, mas a divergência entre as opiniões obstaram a continuidade do projeto, e, durante a Guerra Fria essa proposta manteve-se bloqueada, até que, em 1989, a pedido de Trinidad e Tobago, a ONU requisitou à Comissão que seguisse o projeto de criação de uma corte internacional penal competente para julgar também o tráfico de drogas. ${ }^{225}$

\footnotetext{
${ }^{222}$ Estatuto de Roma, arts. 6, 7 e 8.

223 PERRONE-MOISÉS, Cláudia. Imunidades de chefes de Estado e crimes internacionais. Tese de Livre Docência apresentada na Faculdade de Direito da USP, 2009, p. 11.

${ }^{224}$ Idem, p. 10.

${ }^{225}$ Sítio do Tribunal Penal Internacional: http://www.icc-cpi.int/Menus/ICC
} 
Em 1994 a Comissão apresentou o projeto de um estatuto para um tribunal penal internacional, e submeteu à Assembléia Geral da ONU, que criou um Comitê Ad-Hoc para o estabelecimento desse tribunal. No ano seguinte o Comitê apresentou seu relatório à Assembléia Geral, que designou a criação de um Comitê Preparatório para o Estabelecimento de um Tribunal Penal Internacional, com o fim de preparar um projeto para submeter em uma conferência diplomática, finalizando o projeto em abril de 1998. Em 17 de julho de 1998, durante a Conferência de Plenipotenciários de Roma, o Estatuto de Roma foi adotado, com a participação de 160 Estados, 33 organizações intergovernamentais, e a Coalisão de 236 organizações não-governamentais, sendo que 120 Estados votaram a favor, 7 contra e 21 se abstiveram. O TPI não foi estabelecido como órgão da ONU, mas como uma organização independente, com orçamento independente. Em 11 de abril de 2002 o estatuto do TPI obteve as 60 ratificações necessárias para entrar em vigor, de modo que em 1 de julho de 2002, qualquer pessoa que cometa algum dos crimes tipificados nesse tratado pode ser processado e julgado por essa corte. ${ }^{226}$

O genocídio, destruição intencional de grupos, foi primeiro concebido como crime contra a humanidade, mas adquiriu significado autônomo como um crime específico a partir de 1948, com a Convenção para a Prevenção e a Repressão do Crime de Genocídio. A convenção qualifica o crime de genocídio contra os direitos humanos que pode ser cometido em tempos de paz ou em tempos de guerra, e é entendido como o crime dos crimes, o mais grave dos crimes contra a humanidade. O próprio Estatuto de Roma tipifica-o isoladamente aos outros crimes. Para Celso Lafer ${ }^{227}$ em sua leitura da análise de Hannah Arendt no caso Eichmann, o genocídio não é uma discriminação em relação a uma minoria, não é um assassinato em massa, não é um crime de guerra nem um crime contra a paz. É um crime burocrático sem precedentes, cometidos por pessoas aterradoramente normais, como o Eichmann. Assim, o genocídio representa um ataque à diversidade humana como tal. Para Arendt, o genocídio é então um crime contra a humanidade, perpetrado no corpo do povo judeu, porque visa a eliminar a diversidade e a pluralidade que caracterizam a condição humana ${ }^{228}$.

\footnotetext{
${ }^{226}$ Idem.

${ }^{227}$ LAFER, Celso. A reconstrução dos direitos humanos: um diálogo com o pensamento de Hannah Arendt. São Paulo: Companhia das Letras, 1998, p. 179.

${ }^{228}$ ARENDT, Hannah. Eichmann em Jerusalém - Um relato sobre a banalidade do mal. São Paulo: Companhia das Letras, 1999.
} 
Conforme o Estatuto de Roma, os crimes contra a humanidade são aqueles ataques generalizados ou sistemáticos, lançados contra uma população civil. São eles: homicídio, extermínio, escravidão, deportação ou transferência à força de uma população, prisão ou outra forma de privação da liberdade de modo contrário às normas internacionais, tortura, violências no campo sexual, perseguição de grupos e coletividades, apartheid, desaparecimento forçado de pessoas, e outros atos desumanos de caráter semelhante que causem intencionalmente grande sofrimento, ferimentos graves. Importante ressaltar que são crimes imprescritíveis, o que traz ao debate, por exemplo, a possibilidade de julgar internamente os criminosos das ditaduras recentes da América Latina.

Para distinguir os crimes contra a humanidade de atos isolados, a comunidade internacional estabeleceu critérios tais como ser um ataque generalizado e sistemático contra um grupo relativamente numeroso; que os atos inumanos sejam dirigidos a uma multiplicidade de vítimas; e pelo efeito singular de um ato inumano de uma amplitude extraordinária. Assim, um ato único pode constituir crime contra a humanidade, como decidiu o TPI para a ExIugoslávia no caso Hospital de Vukovar ${ }^{229}$, esses crimes devem ser distinguidos dos crimes de guerra contra pessoas. Um único ato pode evidenciar as características de um crime contra a humanidade, e o indivíduo pode ser culpado se seus atos forem parte de um contexto de violação identificada como crimes contra a humanidade. A internacionalização dos crimes contra a humanidade é consagrada pela comunidade internacional. Ainda no caso Erdemovic $^{230}$, o TPI para a Ex-Ioguslávia apontou que aqueles crimes não eram de caráter interno. São de caráter universal, reconhecidos no direito internacional como violações graves de direitos humanos e que transcendem os interesses de um Estado. Assim, não há que se ter objeção a um tribunal legalmente constituído para julgar esses crimes em nome da comunidade internacional.

Desse modo, a destruição daquilo que há de humano no homem constitui crime contra a humanidade, como faz o crime de desaparecimento forçado. A noção de crimes contra a humanidade é nova, e só entra no debate jurídico a partir de Nuremberg. Esses crimes não tinham precedente específico no passado, e procuravam tipificar o ineditismo da dominação totalitária, que pelas suas características próprias tinha uma especificidade que transcendia os

\footnotetext{
${ }^{229}$ ASCENSIO, Hervé ; DECAUX, Emmanuel; PELLET, Allain (orgs.). Droit International Pénal. Paris: A. Pedone, 2000, pp. 293-9.

${ }^{230}$ Idem.
} 
crimes contra a paz e os crimes de guerra. Eles designam certos fatos graves de violência cometidos por indivíduos, que são ou não agentes do Estado, contra outros indivíduos por motivos políticos, ideológicos, raciais, nacionais, étnicos ou religiosos. ${ }^{231}$

A idéia de humanidade está associada à gravidade dos atos, que se caracteriza por gerar sérias conseqüências. Todavia, esse critério é totalmente subjetivo, e é a comunidade internacional que determina se o ato cometido foi ou não grave, de modo que vai definindo os crimes internacionais em tratados. Ela visa, com a gravidade desses crimes, não somente constituir um elemento de classificação, mas também fundar sua internacionalização, a partir das vítimas. O crime contra a humanidade introduz a categoria de vitimização absoluta. Simboliza a vítima do sacrifício, a passividade total, a vitória definitiva sobre o corpo do outro que é excluído mesmo do combate; ela encarna um novo ser no mundo, ou melhor, um não-ser. ${ }^{232} \mathrm{~A}$ humanidade traz à reflexão o significado da desumanização ${ }^{233}$, que não se consuma com a morte física, mas na morte antes da morte. A vítima prova da experiência de total não pertencimento do mundo que é uma das experiências mais radicais e desesperadas do homem. Ela passa a não pertencer mais a nenhum mundo político; a nenhum Estado, a nenhuma terra, a nenhuma família. É a retirada do direito a ter direitos, e o testemunho do desaparecimento das relações humanas como fundamento da política, pois destrói a singularidade insubstituível de um ser humano. Nesse sentido, recorre-se ao que Hannah Arendt $^{234}$ designa como $^{2}$ pluralidade humana, que engloba aspectos da igualdade e diferença, aparentemente excludentes, mas que manifestam a distinção do ser humano em relação aos outros seres da natureza. As pessoas são iguais por entenderem-se, entender o passado de sua espécie, e planejar o futuro. São diferentes porque cada pessoa possui diversas opiniões e experiências diante dos assuntos humanos. Essa diferença significa que todas as pessoas são capazes de exprimir o que pensam acerca dos assuntos compartilhados por todos, e serem únicas no mundo.

Pode-se considerar, dessa forma, o direito como o ente absoluto na tipificação desses crimes como também absoluto na punição a eles. Nessa perspectiva, os crimes contra a humanidade,

\footnotetext{
231 Idem.

232 GARAPON, Antoine. Des crimes qu'on ne peut ni punir ni pardonner: pour une justice internationale. Paris: Odile Jacob, 2002, p.125-152.

${ }^{233}$ Idem, p. 130-7.

${ }^{234}$ ARENDT, Hannah. O que é política? Rio de Janeiro: Bertrand Brasil, 1999.
} 
como sugerido por Delmas-Marty ${ }^{235}$, aparecem como uma possibilidade de construção de valores comuns a todo o coletivo humano. Significa que esses crimes podem referenciar a elaboração do que é comum a todos os povos, independentemente das diferenças culturais. Isso porque, a despeito de todas as divergências que têm, o valor humanidade liga e identifica todos os seres humanos.

[...] é para o lado das vítimas que é preciso estar voltado para procurar valores comuns, apesar das civilizações diferentes, talvez até opostas. Mesmo nos países em que o estupro e a tortura não são tipificados como tais, nem sancionados penalmente, podemos pensar que as vítimas devem se sentir, contudo, humilhadas, ultrajadas em sua dignidade de ser humano. E a mesma observação diz respeito às crianças quando são vítimas de tratamento desumano ou degradante, talvez até de tortura ou de escravidão. Onde quer que estejamos, tais práticas suscitam indignação, no sentido próprio de um termo que nos envia precisamente à dignidade do ser humano. ${ }^{236}$

Nesse sentido, os crimes internacionais de direitos humanos configurariam um esboço de uma simbologia comum, a despeito dos relativismos. A questão que se lança é a possibilidade da comunidade humana enriquecer-se com a diversidade, buscando o consenso como fundamento das relações humanas. Assim, a busca de valores comuns pressuporia não apenas a enumeração dos comportamentos criminosos, mas também a definição desse fundo comum de valores chamados de humanidade.

É, portanto a despersonalização das vítimas que, chegando à negação de sua humanidade, fundamentaria o crime contra a humanidade, inclusive em determinados casos qualificados hoje como terrorismo. $\mathrm{O}$ que emanaria assim de modo implícito da noção penal de crime contra a humanidade é a consagração de uma humanidade plural, envolvendo ao mesmo tempo a singularidade de cada ser e sua igual vinculação com a comunidade humana. ${ }^{237}$

$\mathrm{Na}$ direção da construção de valores comuns por meio da tipificação e denominação dos crimes contra a humanidade, proposto por Delmas-Marty, inevitável que se reflita acerca da punição a esses crimes, como outra forma de estabelecer uma unidade universal à humanidade. Isso porque, para esses crimes não existe proporção para aplicação de pena, não há como retribuir o dano causado. Nesse sentido, o direito depara-se com o problema de saber qual é a punição suficiente. Isso porque a configuração de crimes dessa natureza e sua complexidade invoca ao direito estabelecer qual é a punição justa, o que significa abandonar o

${ }^{235}$ DELMAS-MARTY, Mireille. Os crimes internacionais podem contribuir para o debate entre universalismo e relativismo de valores? In: CASSESSE, Antonio e DELMAS-MARTY, Mireille (orgs.) Crimes Internacionais e Jurisdições Internacionais. São Paulo: Manole, 2004, pp. 61-72.

${ }^{236}$ Idem, p. 69.

${ }^{237}$ Idem, p. 72. 
equilíbrio da justiça representado pela balança e instaurar um princípio absoluto, ilustrado pela presença da espada. E a punição tem uma função de espiar a culpa de um indivíduo que atenta contra o princípio da humanidade, e tentar, de alguma forma, promover alguma reconciliação no tecido social. Nesse sentido, a punição realizada pelo direito poderia ser entendida como o grau máximo de sua possibilidade de atuar sobre as relações humanas. Assim, o direito internacional penal seria arrebatador em relação aos direitos humanos, na medida em que não propõe compensação, e sim purificação, por meio da punição às afrontas cometidas contra a humanidade.

\subsection{Interdependência dos ramos do direito internacional público}

Nesse esteio, Perrone-Moisés trata do direito internacional penal em confluência com os outros ramos do direito internacional público, apontando que sua interface com o direito internacional dos direitos humanos reside no fato de os crimes tipificados por aquele ramo são as graves violações de direitos humanos, ou seja, nem toda violação constitui crime, somente aquelas mais graves eleitas pela comunidade internacional. Quanto ao direito internacional humanitário, "o julgamento e aplicação de pena das condutas consideradas crimes de guerra" constitui essa estreita relação ${ }^{238}$. Analisa do seguinte modo:

[...] destinado a responder, de forma vigorosa e efetiva, às atrocidades cometidas em tempos de guerra ou de paz, consideradas crimes internacionais. Trata-se de ramo híbrido, pois é impregnado de noções, princípios e construções jurídicas derivadas dos direitos penais nacionais e da normativa dos direitos humanos. Essa heterogeneidade de fontes normativas resulta num conjunto complexo de padrões presentes neste ramo do direito. Para Cassese, a relação entre o direito internacional penal e o direito internacional dos direitos humanos pode ser vista de duas formas: de um lado, os tratados de direitos humanos e a jurisprudência produzida pelas Cortes regionais de direitos humanos vêm contribuindo para o desenvolvimento do direito internacional penal, expandindo, reforçando e criando maior sensibilidade em relação aos valores protegidos por esse ramo do direito internacional público, como a vida e a dignidade humana; por outro lado o direito internacional dos direitos humanos protege o direito das vítimas, das testemunhas e, não menos importante, constitui fonte de proteção das garantias processuais dos acusados. No que diz respeito à relação com os direitos internos, cabe lembrar que muitas noções do direito internacional penal foram transpostas dos direitos nacionais penais e de sua jurisprudência. $^{239}$

238 PERRONE-MOISÉS, Cláudia. Imunidades de chefes de Estado e crimes internacionais. Tese de Livre Docência apresentada na Faculdade de Direito da USP, 2009, p. 7-8.

${ }^{239}$ Idem, pp. 5-6. 
Dessa maneira, pode-se depreender especialmente cinco elementos de complementaridade e convergência entre o direito internacional dos direitos humanos e o direito internacional penal, tais quais a construção da figura da pessoa como sujeito de direito internacional, adquirindo assim personalidade jurídica; a conceitualização dos crimes contra a humanidade; a relação complementar entre a responsabilidade internacional do Estado e dos indivíduos; a prevenção e garantia de não-repetição e a justiça reparatória estabelecida por essas duas vertentes do direito internacional público. ${ }^{240}$

A concepção dos dois ramos do direito internacional acerca da compreensão do indivíduo como sujeito de direito internacional, de modo ativo no direito internacional dos direitos humanos, e passivo no direito internacional penal, constitui a grande ruptura para o direito internacional clássico, na medida em que lança o indivíduo à ação em escala internacional, o que significa ter voz para além do seu Estado nacional, bem como responder por seus atos na mesma escala de amplitude. Pode-se depreender dessa nova condição do sujeito em esfera mundial uma forma mais autônoma de existência diante daquele conceito de humanidade tratado ao longo deste capítulo.

Adicionalmente, a participação do sujeito nas jurisdições internacionais mostra-se de maneira ativa no curso de seus procedimentos, seja em razão de ser vítima do processo, ou testemunha nos julgamentos de violações de direitos humanos nas cortes de direitos humanos. A exemplo das jurisdições de direitos humanos, o TPI tem previsto em seus procedimentos a participação da vítima, de modo que se estabelece também como justiça reparatória, pois mesmo sendo punitiva e sancionatória, prevê formas de reparação individuais e coletivas ${ }^{241}$. Ainda quanto à personalidade jurídica internacional do indivíduo, a consolidação da responsabilidade individual devido à prática de crimes internacionais, imputando deveres aos sujeitos, fortalece o controle no direito internacional por abusos cometidos, confirmando que o indivíduo é sujeito de direito internacional.

Um segundo ponto de aproximação da relação entre o direito internacional dos direitos humanos e direito internacional penal reside no fato de que a conceitualização dos crimes contra a humanidade deriva das diretrizes estabelecidas pelo direito internacional dos direitos humanos. Assim, os crimes tipificados pelo direito internacional penal visam à condenação

${ }^{240}$ Caso Goiburú e outros vs. Paraguai, sentença de mérito, voto arrazoado Cançado Trindade, pp. 1-23.

${ }^{241}$ Estatuto de Roma, art. 75. 
universal das graves e sistemáticas violações de direitos humanos inderrogáveis, ou seja, de ius $\operatorname{cogens}^{242}$. Ademais, a prática de crimes contra a humanidade tem amparo nas políticas estatais, na medida em que seus perpetradores contam com o uso das instituições do Estado, seus recursos, de forma planejada e calculada. São, nesse sentido, crimes de Estado, organizados por uma política criminal estatal. Dessa maneira, o cometimento de crimes contra a humanidade compromete a responsabilidade tanto do Estado quanto dos indivíduos que executam essas diretrizes de crimes cometidos sob as diretrizes de uma política de Estado. Dessa maneira, como o fim desses ramos do direito internacional é de, no limite, tutelar os direitos humanos, evidencia-se a complementaridade entre esses dois ramos, na medida em que tanto o Estado como os indivíduos são responsáveis por garantir sua eficácia. E, caso algum desses sujeitos descumpram, respondem, cada qual em sua condição, perante a comunidade internacional.

Quanto à prevenção e garantia de não-repetição, ambos os ramos do direito visam a esses dois princípios e ao combate à impunidade, cada um a sua maneira. Em caso de graves violações de direitos humanos, o direito internacional dos direitos humanos determina reparações exemplares como conseqüência dos crimes de Estado, enquanto o direito internacional penal, determina punição àqueles que, em nome de uma política de Estado, cometeram atos de genocídio, crimes contra a humanidade ou crimes de guerra. Nessa perspectiva, não cabe invocar limitações próprias de direito interno, nem prescritibilidade ou prescrição punitiva em casos de violação a normas de direitos humanos e direito internacional humanitário, assim como não há coisa julgada que vincule as jurisdições internacionais para apreciar casos dessa natureza.

Independentemente do reconhecimento da titularidade de direitos humanos ser da pessoa humana, emanados do direito internacional dos direitos humanos, há também a compreensão de que também estipula deveres aos indivíduos, ou seja, a violação de determinados direitos, constituindo os crimes contra a humanidade, tem decorrência na responsabilidade penal internacional, independentemente do que disponha legislação interna acerca da matéria. Desse modo, o indivíduo é tanto portador desses direitos, como de obrigações emanadas diretamente de ambos os ramos do direito internacional, como da jurisdição universal.

${ }^{242}$ PERRONE-MOISÉS, Cláudia. Imunidades de chefes de Estado e crimes internacionais. Tese de Livre Docência apresentada na Faculdade de Direito da USP, 2009, pp. 6-16. 
Depreende-se, dessa forma, que os três ramos, direito internacional humanitário, direito internacional dos direitos humanos, direito internacional penal constituem guardiões do princípio de humanidade que, como já apresentado, é completamente retirado das vítimas do desaparecimento forçado. Todos traçam em suas normativas, a partir de seus princípios e objetivos, o arcabouço jurídico necessário e que se complementa com vistas a proteger as pessoas do desaparecimento forçado de pessoas. É preciso, contudo, abrir cada vez mais espaços para a combinação dos modelos da jurisdição nacional e internacional; talvez por meio da possibilidade de criação de sistemas jurídicos mais rizomáticos e menos hierárquicos, para a proteção dos valores comuns refletidos no ordenamento dos três ramos do direito internacional público. 


\section{Direito à Verdade e os CASOS de desaparecimento da CoRTe INTERAMERICANA DE DIREITOS HUMANOS}

Conceitualmente, podemos chamar de verdade aquilo que não podemos modificar; metaforicamente, ela é o solo sobre o qual nos colocamos de pé e o céu que se estende acima de nós. 243

\subsection{Sobre a verdade}

Independentemente do que se considere por verdade ${ }^{244}$, especialmente em âmbito político, já que a discussão acerca deste conceito nunca teve tanta atenção da filosofia ou ciências ${ }^{245}$, importa o quão decisiva é para a formação das identidades individuais e coletivas, de modo que a "verdade só tem sentido para e pelo homem"246. Dessa maneira, é por meio da referência implícita ou não da verdade que se baseiam as comunicações humanas, e conseqüentemente suas relações. Quando os indivíduos tornam-se ameaças a outros ou a grupos sociais, pela violência ou "manipulação da verdade, o processo de construção de identidades é posto em risco", dando lugar à desconfiança, ao medo, à intolerância entre as pessoas, prejudicando a formação livre das identidades, sejam individuais ou coletivas ${ }^{247}$.

Nesse sentido, a verdade está associada às instâncias de poder; por isso, é necessário que os homens atuantes tenham disposição pública e espírito republicano para partilharem as

\footnotetext{
243 ARENDT, Hannah. Verdade e Política. In Entre o passado e o futuro. São Paulo: Perspectiva, 2003, p. 325.

${ }^{244}$ A palavra usada pelos gregos correspondente à verdade é aletheia, da raiz lethé (esquecimento). Assim, ela significa exatamente inesquecido, como se a verdade estivesse associada à lembrança dos acontecimentos.

${ }^{245}$ ARENDT, Hannah. A mentira na política - Considerações sobre os documentos do Pentágono. In Crises da República. São Paulo: Perspectiva, 2004, p. 15: “A veracidade nunca esteve entre as virtudes políticas, e mentiras sempre foram encaradas como instrumentos justificáveis nestes assuntos. Quem quer que reflita sobre estas questões ficará surpreso pela pouca atenção que tem sido dada ao seu significado na nossa tradição de pensamento político e filosófico; por um lado, pela natureza da ação, e por outro, pela natureza de nossa capacidade de negar um pensamento e palavra qualquer que seja o caso. Esta capacidade atuante e agressiva é bem diferente de nossa passiva suscetibilidade em sermos vítimas de erros, ilusões, distorções de memória, e tudo que possa ser culpado pelas falhas de nossos mecanismos sensuais e mentais".

${ }^{246}$ SAMPAIO, José Adércio Leite e ALMEIDA, Alex Luciano Valadares de. Verdade e história: por um direito fundamental à verdade. In: SOARES, Inês Virgínia Prado e KISHI, Sandra Akemi Shimada. Memória e Verdade - A justiça de transição no Estado Democrático Brasileiro. Belo Horizonte: Fórum, 2009, p. 250.

${ }^{247}$ Idem, p. 250.
} 
informações e verdades no sentido de construção identitária dos indivíduos e sociedades ${ }^{248}$. Contudo, Hannah Arendt ao analisar as características da mentira política, aponta que o

Sigilo - diplomaticamente chamado de "discrição" e de arcana imperii (os mistérios do governo) - e embuste, ou seja, a falsidade deliberada e a mentira descarada, são usados como meio legítimos para alcançar fins políticos desde os primórdios da história documentada. A veracidade nunca esteve entre as virtudes políticas, e as mentiras sempre foram encaradas como instrumentos justificáveis nestes assuntos. $^{249}$

Para que mudanças e transformações da vida política sejam possíveis, é necessário destruir ou remover aquilo que já estava dado, e isso não aconteceria se não se imaginasse o que poderia acontecer. Como afirma a mesma autora, “(...) a negação deliberada da verdade dos fatos isto é, a capacidade de mentir - e a faculdade de mudar os fatos - a capacidade de agir - estão interligadas; devem suas existências à mesma fonte: à imaginação". ${ }^{250}$ Pode-se extrair dessa afirmação arendtiana que, para se destruir ou remover o passado é necessário saber a verdade para então construir ou imaginar as ações políticas que fundarão um futuro, diverso daquele passado. Por isso os fatos não devem ter sua fonte na imaginação, mas na verdade dos acontecimentos, para que as pessoas possam imaginar um futuro transformado e diferente do passado. Assim, Perrone-Moisés, em sua análise acerca da verdade em Hannah Arendt, coloca: "A verdade política relaciona-se com os acontecimentos e fatos: aquilo que não se pode mudar. A verdade filosófica se relaciona a algo que não poderia ser diferente do que é." 251

“Os homens atuantes, quando se sentem donos de seus próprios futuros, ficarão eternamente tentados a se fazerem donos do passado também." 252 Dessa maneira, assim como os grandes mentirosos, seu objetivo é livrarem-se dos fatos, e crêem que isso é possível devido a sua própria contingência. Contudo, o simples motivo de muita gente acreditar que os fatos não

\footnotetext{
${ }^{248}$ Idem, p. 251.

${ }^{249}$ ARENDT, Hannah. A mentira na política - Considerações sobre os documentos do Pentágono. In Crises da República. São Paulo: Perspectiva, 2004, p. 14.

${ }^{250}$ Idem, p. 15.

${ }^{251}$ PERRONE-MOISÉS, Cláudia. Verdade, opinião, mentira. In Hannah Arendt Handbook, 2008, no prelo. “A verdade filosófica, ao penetrar na praça pública, altera sua natureza e se torna opinião. [...] A verdade fatual, ao contrário, relaciona-se sempre com outras pessoas: ela diz respeito a eventos e circunstâncias nas quais muitos são envolvidos; é estabelecida por testemunhas e depende de comprovação; existe apenas na medida em que se fala sobre ela, mesmo quando ocorre no domínio da intimidade. É política por natureza." ARENDT, Hannah. Verdade e Política. In Entre o passado e o futuro. São Paulo: Perspectiva, 2003, p. 295.

${ }^{252}$ ARENDT, Hannah. A mentira na política - Considerações sobre os documentos do Pentágono. In Crises da República. São Paulo: Perspectiva, 2004, p. 20.
} 
ocorreram, não é suficiente para que eles sejam removidos do mundo. ${ }^{253}$ "Talvez seja natural para os que ocupam cargos eletivos imaginar que manipulação é o que dirige a mente das pessoas e portanto é o que realmente dirige o mundo". ${ }^{254}$ Entretanto, o Estado democrático não é capaz de conviver com a mentira, por mais bem intencionada que seja, pois tem como princípio filosófico a liberdade e autonomização dos sujeitos, e, para atingi-lo, carece de fluxo livre das informações públicas ${ }^{255}$, que dizem respeito aos assuntos humanos.

\begin{abstract}
A falsidade deliberada, a manipulação de fatos e opiniões, tem a ver com a mentira organizada cujo exemplo para Arendt mais acabado foram os regimes totalitários. As mentiras fazem parte do arsenal da ação política. A falsidade deliberada é o oposto da verdade factual e essa, dificilmente sobrevive ao assédio do poder. A mentira organizada tende a suprimir aquilo que pretende negar e os governos totalitários adotaram a mentira como primeiro passo para a destruição. ${ }^{256}$
\end{abstract}

Quanto à restrição aos documentos produzidos, Hannah Arendt aponta um "dos mais graves perigos da restrição exagerada: ao povo e seus representantes eleitos é negado acesso àquilo que precisam saber para formar opinião e tomar decisões, e os protagonistas, que recebem autorização superior para conhecer todos os fatos relevantes, mantém-se bemaventuradamente ignorante a eles". ${ }^{257}$ Desse modo, a despeito de a verdade fatual ser essencial para a formação das opiniões, e, com isso, o exercício da política, é recorrentemente aqueles que estão no poder que querem ocultá-la, escondê-la e, como apontou PerroneMoisés, é um dos primeiros passos para uma política totalitária.

\title{
3.1.2. O direito à verdade no direito internacional
}

O direito à verdade está intimamente relacionado com o desaparecimento forçado de pessoas, pois o Direito Internacional Humanitário já previa, nos arts. 32 e 33 do Protocolo Adicional I das Convenções de Genebra de 1949, o direito das famílias de saberem do paradeiro dos combatentes durante conflitos armados. A Convenção Internacional sobre Desaparecimento Forçado também trata disso em seu preâmbulo e art. 24. Contudo, como o direito à verdade

\footnotetext{
${ }^{253}$ Idem, p. 21.

${ }^{254}$ Idem, p. 25.

${ }^{255}$ SAMPAIO, José Adércio Leite e ALMEIDA, Alex Luciano Valadares de. Verdade e história: por um direito fundamental à verdade. In: SOARES, Inês Virgínia Prado e KISHI, Sandra Akemi Shimada. Memória e Verdade - A justiça de transição no Estado Democrático Brasileiro. Belo Horizonte: Fórum, 2009, p. 253.

${ }^{256}$ PERRONE-MOISÉS, Cláudia. Verdade, opinião, mentira. In Hannah Arendt Handbook, 2008, no prelo.

${ }^{257}$ ARENDT, Hannah. A mentira na política - Considerações sobre os documentos do Pentágono. In Crises da República. São Paulo: Perspectiva, 2004, p.35.
} 
não é expresso autonomamente por norma de direito internacional ${ }^{258}$, ele pode ser compreendido como emanado de direito costumeiro ou princípio geral do direito ${ }^{259}$. Este direito não aparece especificamente em nenhum tratado de direitos humanos, mas está contido em outros documentos internacionais, além de estar incorporado nas legislações nacionais ${ }^{260}$. Ademais, diversos instrumentos produzidos em âmbito internacional desde 1974, relacionados ao desaparecimento de pessoas, já tratavam do direito à verdade como uma "necessidade humana básica" ${ }^{261}$. Conforme leciona Perrone-Moisés,

$\mathrm{O}$ direito à verdade visa ao conhecimento e ao reconhecimento. $\mathrm{O}$ conhecimento consiste na verdade dos fatos que, a partir da evidência acumulada, já não pode ser negada. O reconhecimento, a seu turno, é uma espécie de transformação que sofre a verdade histórica, quando assumida de forma oficial pela sociedade e pelo Estado. Trata-se de impedir que se possam negar determinados fatos relacionados a atrocidades cometidas, a exemplo do que ocorre com o "negacionismo", no Holocausto e, em muitos países da América do Sul, no que se refere aos abusos não reconhecidos pelas ditaduras militares. ${ }^{262}$

O Conjunto de Princípios para a proteção e promoção dos direitos humanos através da luta contra a impunidade ${ }^{263}$, apresentado à Comissão de Direitos Humanos em sua $49^{\circ}$. sessão, é fruto de uma campanha contra a impunidade, que pode ser dividida em quatro estágios. A primeira fase foi iniciada na década de 1970, quando começaram a surgir comitês de anistia nas ditaduras da América Latina encampados por organizações não-governamentais e advogados de direitos humanos, com vistas a resolver a questão dos presos políticos. Nos anos de 1980 os próprios governos de exceção passaram a declarar anistias visando à elaboração da transição democrática, estabelecendo, então, as auto-anistias. No fim dessa

\footnotetext{
${ }^{258}$ Quanto à consagração do direito à verdade em âmbito da ONU, ver Conjunto de Princípios para a proteção e promoção dos direitos humanos através da luta contra a impunidade - Relatório Joinet E/CN.4/Sub.2/1997/20/Rev.1; Conjunto de Princípios sobre deslocados internos - E/CN.4/1998/53/Add.2; Reparações devidas às vítimas de violações graves de direitos humanos - Res. Comissão de Direitos Humanos 2005/35 e da AG 60/147; Leis de Anistia como obstáculo ao exercício do direito à verdade - Res. Comissão DH 1989/62. Parágrafo 7 (b); Relatório do Alto Comissariado das Nações Unidas para os direitos humanos: Estudos sobre direito á verdade - E/CN.4/2006/91. Em âmbito da OEA, o direito à verdade é reconhecido tanto pela Comissão quanto pela Corte, embora a primeira manifeste que este direito tem caráter coletivo, e titularidade da sociedade no que concerne ao desenvolvimento dos regimes democráticos, enquanto a Corte não admite a autonomia deste direito, condicionando-o ao devido processo legal e à eficácia do Judiciário. (informação oral) PERRONE-MOISÉS, Cláudia. Verdade e Justiça, Conferência Internacional sobre o Direito à Verdade, São Paulo, 19 e 20 de outubro de 2009.

259 NAQVI, Yasmin. The right to the truth in international law: fact or fiction? In International Review of the Red Cross, vol. 88, n. 862, jun. 2006, p. 254.

${ }^{260}$ Idem, p. 255.

${ }^{261}$ Idem, p. 256.

262 PERRONE-MOISÉS, Cláudia. Imunidades de chefes de Estado e crimes internacionais. Tese de Livre Docência apresentada na Faculdade de Direito da USP, 2009, p. 89.

${ }^{263}$ Documento E/CN.4/Sub.2/1997/20/Rev.1, de 2 de outubro de 1997. Esse relatório é resultado de um estudo acerca da impunidade, elaborado pelo relator especial Louis Joinet, solicitado pela Sub-Comissão para prevenção de discriminação e proteção das minorias, em 1991.
} 
década, com a queda do Muro de Berlim e o fim da Guerra Fria, diversos processos de democratização tiveram início, em seguida aos conflitos internos, e, nesse momento de transição, a questão da impunidade passou a vir à tona. $\mathrm{O}$ último estágio diz respeito ao momento em que a comunidade internacional consagrou a luta contra a impunidade como matéria de relevância, na segunda Conferência Mundial de Direitos Humanos, em sua Declaração e Programa de Açãode Viena.

Esse Relatório introduz o direito à verdade como um dos direitos das vítimas, ao lado dos direitos à justiça e à reparação. Define o direito à verdade da seguinte maneira:

O direito à verdade não é simplesmente o direito de uma vítima individual ou de alguma pessoa próxima saber o que aconteceu. $\mathrm{O}$ direito à verdade é também um direito coletivo, baseando-se na história para prevenir que ocorram violações no futuro. Seu corolário é o "dever de memória" que os Estados devem assumir, com vistas a garantir que não haja distorções na história, com os chamados revisionismo ou negacionismo; o conhecimento da opressão vivida em um país é parte da herança nacional de um povo e deve ser preservada. Assim, esses são os principais objetivos do direito à verdade como um direito coletivo. ${ }^{264}$

Em 2005 o Relatório Joinet foi atualizado ${ }^{265}$, reorganizando assim aquele conjunto de princípios. Esta atualização que tem como objetivo principal a obrigação dos Estados de agirem contra a impunidade, estabelece as medidas para o enfrentamento da impunidade, reafirmando que o direito à verdade é um princípio, que, composto com os outros princípios de justiça e reparação, estabelecem as diretrizes para auxiliarem os Estados a combaterem a impunidade ${ }^{266}$. Dessa maneira, estabelece não só que o direito à verdade é inalienável ${ }^{267}$, mas também que há um dever do Estado de preservação da memória ${ }^{268}$, e que as vítimas têm o

264 Idem, Item A, 17: This is not simply the right of any individual victim or closely related persons to know what happened, a right to the truth. The right to know is also a collective right, drawing upon history to prevent violations from recurring in the future. Its corollary is a "duty to remember", wich the States must assume, in order to guard against the perversions of history that go under the names of revisionism or negationism; the knowledge of the oppression it has lived through is part of a people's national heritage and as such must be preserved. These, then, are the main objectives of the right to know as a collective right.

265 Relatório E/CN.4/2005/102/Add.1, de 08 de fevereiro de 2005, atualização do Relatório Joinet E/CN.4/Sub.2/1997/20/Rev.1, por Diane Orentlicher.

${ }^{266}$ Idem, Preâmbulo: Pursuant to the Vienna Declaration and programme of Action, the following principles are intended as guidelines to assist States in developing effective measures for combating impunity.

${ }^{267}$ Idem, Princípio 2: Every people hás the inalienable right to know the truth about past events concerning the perpetration of heinous crimes and about the circumstances and reasons that led, through massive or systematic violations, to the perpetration of those crimes. Full and effective exercise of the right to the truth provides a vital safeguard against the recurrence of violations.

${ }^{268}$ Idem, Princípio 3: A people's knowledge of the history of its oppression is part of its heritage and, as such, must be ensured by appropriate measures in fulfilment of the State's duty ti preserve archives and other evidence concerning violations of human rights and humanitarian law and to facilitate knowledge of those violations. 
direito de saberem ${ }^{269}$ as circunstâncias das violações e, em caso de desaparecimento, o destino das vítimas.

Para a realização desse direito à verdade, em contextos transicionais, é fundamental o estabelecimento de comissões extrajudiciais de investigação das violações de direitos humanos e a preservação dos arquivos que relatam tais violações. Dessa forma, o direito à verdade, para as vítimas e familiares, significa que o Estado tem a obrigação de fornecer todas as informações acerca das circunstâncias em que a grave violação de direitos humanos ocorreu, assim como do acontecido com as vítimas. Para a sociedade em geral, o direito à verdade impõe que o Estado revele as informações relativas às razões que levaram à prática das graves violações, bem como as circunstâncias que as motivaram, com o fim de desenvolver ações para a compreensão e reconciliação com o ocorrido, conforme a atualização do Conjunto de Princípios para a proteção e promoção dos direitos humanos através da luta conta a impunidade ${ }^{270}$.

As comissões de verdade constituem um senso de obrigação legal para prover a verdade, para atender as necessidades da sociedade, das vítimas diretas e indiretas, para saberem o que aconteceu, com o fim de contribuir com o processo de reconciliação, e com a luta contra a impunidade, para reinstalar o processo democrático, o Estado de Direito e a confiança nas autoridades governamentais e, finalmente, para prevenir a repetição de eventos futuros. Sua atuação diz respeito as graves violações de direitos humanos e humanitário, referindo-se à época do ocorrido e não apenas às violações, de modo a dizer respeito a toda a sociedade, e não apenas às vítimas e aos agressores, ou aos envolvidos no conflito. Ademais, têm caráter restaurativo e reconciliatório, a despeito do caráter retributivo das sanções penais, relacionando a questão da verdade construída, relativa, com a da absoluta, necessária para a condenação penal do agressor. ${ }^{271}$

Such measures shall be aimed at preserving the collective memory from extinction and, in particular, at guarding against the development of revisionist and negationist arguments.

${ }^{269}$ Idem, Princípio 4: Irrespective of any legal proceedings, victims and their families have the imprescriptible right to know the truth about the circumstances in which violations took place and, in the event of death or disappearance, the victim's fate.

${ }^{270}$ Idem, Princípio 5.

${ }^{271}$ NAQVI, Yasmin. The right to the truth in international law: fact or fiction? In International Review of the Red Cross, vol. 88, n. 862, jun. 2006, pp. 261-3. E/CN.4/Sub.2/1997/20/Rev.1, Relatório Joinet, Princípios: 6. The establishment and role of truth comissions; 7. Guaratees of independence, impartiality and competence; 8 . Definition of a commission's terms of reference; 9. Guarantees for persons implicated; 10. Guarantees for victims and witnesses testifying on their behalf; 11. Adequate resources for commissions; 12. Advisory functions of the comission; 13. Publicizing the comission's reports. 
Outro aspecto para a promoção do direito à verdade, estabelecido pelo Conjunto de Princípios, é a preservação dos arquivos que contém os relatos das violações de direitos humanos, garantindo igualmente o acesso aos arquivos a esses documentos. Assim, declara que devem ser preservados de qualquer destruição, manipulação ou falsificação que levem à impunidade de violadores de direitos humanos. Aos Estados, por sua vez, o Conjunto de Principios reforça o dever de empreenderem esforços para a proteção dos arquivos. Da mesma maneira, o acesso aos arquivos deve ser facilitado, não só para as vítimas, mas para todos que tenham interesse nesses documentos. ${ }^{272}$

Há, então, duas perspectivas para a compreensão do direito à verdade. Uma refere-se a violações individuais de direitos humanos, que demandam respostas específicas a cada situação, como refletem os casos julgados pelas cortes internacionais e os relatórios dos grupos de monitoramento. Outra diz respeito a violações massivas de direitos humanos, caracterizadas pelas práticas sistemáticas como política de Estado; nesses casos é necessário que se revelem as causas e as razões para tais violências, por meio de comissões de verdade e ações da comunidade internacional expressas em resoluções da Assembléia Geral e do Conselho de Segurança ${ }^{273}$. Outra forma utilizada pelo Conselho de Direitos Humanos para estabelecimento do direito à verdade é em relação às reparações às vítimas em caso de graves violações de direitos humanos e direito internacional humanitário.

Em relação à consagração do direito à verdade como direito costumeiro, esse fundamento tem em sua base as práticas nacionais e as normas de direito internacional humanitario. ${ }^{274} \mathrm{Um}$

Para Todorov, as Comissões de Verdade são um meio de educação coletiva próximo da justiça, mas melhor preparados que ela, pois "renunciam à punição, partindo do postulado de que o advento da verdade terá um valor educativo maior que algumas sanções individuais. Finalmente, essas Comissões produzem um trabalho que coloca a sociedade inteira diante de suas responsabilidades, em vez de lhe concedr a comodidade que consiste em designar alguns bodes expiatórios. Assim, a sociedade, cujo erro é na melhor das hipóteses o de deixar fazer, poderá se reconhecer no culpado, e não apenas na instância da justiça." TODOROV, Tzvetan. Os limites da justiça. In CASSESE, Antonio e DELMAS-MARTY, Mireille (org). Crimes Internacionais e Jurisdições Internacionais. São Paulo: Manole, 2004, pp. 42-3.

Para um estudo mais aprofundado acerca das Comissões de Verdade, conferir os trabalhos de Priscilla B. HAYNER: Fifteen Truth Comissions - 1974 to 1994: a comparative study. In Human Rights Quarterly, v. 6, n. 4, Nov. 1994; Truth Comissions: a schematic overview. In International Review of Red Cross, v. 88, n. 862, jun. 2006; Unspeakable Truths: confronting State terror and atrocity. New York: Routledge, 2002.

${ }^{272}$ Relatório E/CN.4/2005/102/Add.1, princípios 14 a 18.

${ }^{273}$ NAQVI, Yasmin. The right to the truth in international law: fact or fiction? In International Review of the Red Cross, vol. 88, n. 862, jun. 2006, p. 260.

${ }^{274}$ E/CN.4/2006/91, p. 5, parágrafo 7: The International Committee of the Red Cross (ICRC) concluded that the right to truth is a norm of customary international law applicable in both international and non-international 
primeiro dado é o fato de mais de trinta países em todas as regiões do mundo onde houve graves violações de direitos humanos, terem instalado comissões de verdade. Contudo, não há base legal nos países, e os instrumentos que expressam o direito à verdade em sua dimensão individual ou coletiva emanam das comissões de verdade ou de mecanismos similares. Entretanto, em diversos países houve a incorporação nas legislações do direito das famílias de saberem o acontecido com seus entes. Apesar desse direito nao ter sido formalmente incorporado às constituições nacionais, estas geralmente reconhecem o acesso e o direito à liberdade de informacao. ${ }^{275}$

Ademais, considera-se que o direito à verdade é direito costumeiro porque, embora esteja explicitado unicamente no Update Principles on Impunity, e na Resolução da OEA sobre direito à verdade ${ }^{276}$, ele sempre aparece em outros documentos, ou em julgamentos de cortes internacionais de direitos humanos em relação com outros direitos humanos. Além disso, o efeito das decisões tomadas pelos tribunais e do desvelamento da verdade promovidos pelos mecanismos extrajudiciais nos casos de graves violações de direitos humanos, assim como as legislações nacionais, e a constante reiteração dos órgãos internacionais da importância de saber da verdade, evidenciam os contornos desse direito como costumeiro ${ }^{277}$.

O estudo sobre o direito à verdade realizado pelo Alto Comissariado das Nações Unidas para os Direitos Humanos ${ }^{278}$, datado de 09 de janeiro de 2006, estabelece em suas conclusões o caráter autônomo e inalienável do direito à verdade, constituindo-se como mais um dos

armed conflict, according to which "each party to the conflict must take all feasible measures to account for persons reported missing as a result of armed conflict and must provide their family members with any information it has on their fate". Military manuals and national laws of several countries also make reference to the right of the families to know the fate of their missing. Parágrafo 30: National courts at the highest level have also recognized the right to the truth. The Constitutional Courts of Colombia and Peru, and the Federal Criminal Courts of Argentina have developed important jurisprudence recognizing and affirming the right to know the truth of victims of gross human rights violations. The Courts of Argentina, in the so-called truth trials, has found that in cases of enforced disappearances the right to the truth is based on the right to mourning (derecho al duelo), and as one of the components of the right to justice, as well as the need for historical clarification, individual and societal healing and the prevention of future violations. The right to the truth has also been considered as a means to ensure a democratic State based on the rule of law. Courts have also noted the contribution of knowing the truth to eradicating impunity.

${ }^{275} \mathrm{NAQVI}$, Yasmin. The right to the truth in international law: fact or fiction? In International Review of the Red Cross, vol. 88, n. 862, jun. 2006, p. 264.

${ }^{276}$ AG/RES. 2267 (XXXVII-O/07).

${ }^{277}$ NAQVI, Yasmin. The right to the truth in international law: fact or fiction? In International Review of the Red Cross, vol. 88, n. 862, jun. 2006, p. 267.

${ }^{278} \mathrm{E} / \mathrm{CN} .4 / 2006 / 91$. 
direitos a serem garantidos pelo Estado ${ }^{279}$. Como já mencionado, o direito à verdade é tradicionalmente tutelado pelo Direito Internacional Humanitário, no que concerne a pessoas desaparecidas, e pelo direito internacional dos direitos humanos em relação a esses mesmos sujeitos, diversas Cortes nacionais e regionais têm entendido que a não revelação da verdade acerca do paradeiro da vítima constitui forma de tortura aos familiares. A natureza do direito à verdade tem relação estreita com outros direitos tais quais à proteção jurídica, às garantias processuais e à reparação ${ }^{280}$.

A OEA, por sua vez, adotou uma Resolução acerca do direito à verdade, datada de 5 de junho de 2007, cujo teor é no sentido de "reconhecer a importância de respeitar e garantir o direito à verdade para contribuir a acabar com a impunidade e promover e proteger os direitos humanos" ${ }^{281}$, alinhado com o Conjunto de Princípios para a proteção e promoção dos direitos humanos através da luta conta a impunidade, que encoraja os Estados-Parte da Organização a desenvolverem mecanismos judiciais e extrajudiciais para a promoção de tal direito, considerado inalienável e autônomo pelo mesmo documento. Adicionalmente, a Resolução solicita à Comissão de Direitos Humanos que apresente um informe acerca do tratamento desse direito em âmbito regional, bem como os mecanismos desenvolvidos para o fim de tutelá-lo.

Dessa maneira, o direito internacional dos direitos humanos, tanto em âmbito global como regional, tem avançado em sua compreensão acerca do caráter autônomo do direito à verdade, e de sua importância não apenas para as vítimas, mas também para a coletividade, na medida em que sua efetividade tem também o condão de reinstaurar ou fortalecer a democracia e o Estado de Direito. Além disso, o direito à verdade também poderia estar relacionado com o princípio de transparência e de boa gestão dos assuntos públicos pelos governos. ${ }^{282}$

\footnotetext{
279 Idem, p. 2: The study concludes that the right to the truth about gross human rights violations and serious violations of human rights law is an inalienable and autonomous right, linked to the duty and obligation of the State to protect and guarantee human rights, to conduct effective investigations and to guarantee effective remedy and reparations. This right is closely linked with other rights and has both an individual and a societal dimension and should be considered as a non-derogable right and not be subject to limitations.

${ }^{280}$ Idem, p. 20, para. 43.

281 AG/RES. 2267 (XXXVII-O/07) 1. Reconocer la importancia de respetar y garantizar el derecho a la verdad para contribuir a acabar con la impunidad y promover y proteger los derechos humanos.

${ }^{282}$ E/CN.4/2006/91, p. 7, para. 14 e p. 19, para. 46.
} 


\subsubsection{Verdade e justiça}

Na perspectiva do Conjunto de Princípios para a proteção e promoção dos direitos humanos através da luta conta a impunidade, o direito à verdade está intimamente relacionado aos direitos à justiça e à reparação. É uma forma de saber o acontecido com as pessoas desaparecidas ou dos fatos em caso de graves violações de direitos humanos ${ }^{283}$. Dessa maneira, a UNESCO, em parceria com o Conselho Internacional de Arquivos, elencou uma gama de direitos individuais e $\operatorname{coletivos}^{284}$ que são violados com o não cumprimento do direito à verdade, especialmente em caso de regimes autoritários, já que os arquivos de Estado constituem o grande registro de todo o acontecido nesse contexto.

Quando se trata de crimes internacionais a verdade deve ser entendida de modo diferente dos crimes comuns, em que o objetivo é verificar a culpa ou inocência de algum indivíduo da prática de um ato, configurando uma justiça retributiva a um ato proibido e sancionado por uma lei penal. Os objetivos de se encontrar a verdade quando se trata de crimes internacionais $^{285}$ dizem respeito à restauração e à manutenção da paz e ao processo de reconciliação nacional ${ }^{286}$.

\footnotetext{
${ }^{283}$ NAQVI, Yasmin. The right to the truth in international law: fact or fiction? In International Review of the Red Cross, vol. 88, n. 862, jun. 2006, p. 249.

${ }^{284}$ SAMPAIO, José Adércio Leite e ALMEIDA, Alex Luciano Valadares de. Verdade e história: por um direito fundamental à verdade. In: SOARES, Inês Virgínia Prado e KISHI, Sandra Akemi Shimada. Memória e Verdade - A justiça de transição no Estado Democrático Brasileiro. Belo Horizonte: Fórum, 2009, pp. 258-9: Em âmbito individual não são possíveis de serem efetivados os seguintes direitos em decorrência do não cumprimento do direito à verdade: à intimidade, à identidade e à verdade familiar, associada a não saber o paradeiro dos desaparecidos; a esclarecer eventuais políticas ou medidas discriminatórias oficiais com repercussões à honra e moral das pessoas; à pesquisa histórica do país; à anistia a prisioneiros políticos e a pessoas que sofreram algum tipo de penalidade em decorrência de seus vínculos ideológicos, religiosos, étnicos ou raciais; à indenização e reparações por prejuízos sofridos pelas vítimas da repressão e à restituição de bens confiscados. Em relação aos direitos coletivos, o estudo estabelece que é violado o direito do povos de escolher seu caminho de transição política; à integridade de sua memória escrita; ao acesso a informações sobre a conduta dos atores sociais no regime passado; a identificar os responsáveis pelos crimes praticados contra os direitos humanos.

${ }^{285}$ A exemplo da Lei 975 e Decreto 4760 ambos de 2005 adotada na Colombia, relativa à verdade, justiça e reparação, elementos chaves para esclarecer a verdade sobre os crimes da ditadura cometidos pelas forças armadas, seriam saber acerca da estrutura militar, financeira, política e redes de apoio com que contava os grupos militares, a totalidade dos crimes cometidos, os pseudônimos e documentos falsos, o armamento utilizado e sua origem, os lugares de cometimento dos crimes, bem como as evidências físicas desses crimes, a titularidade dos bens apropriados indevidamente etc. CEJIL. Justicia y paz em Colombia: El derecho a La verdad, La justicia y La reparación. San Jose: CEJIL, 2006, p. 13.

${ }^{286}$ NAQVI, Yasmin. The right to the truth in international law: fact or fiction? In International Review of the Red Cross, vol. 88, n. 862, jun. 2006, p. 246.
} 
"A busca pela verdade do passado é, antes, uma ação de rejeição à impunidade e ao desrespeito aos direitos, um valor ético, mas também uma ação política"287. Dessa maneira, ela tem também como fim a luta contra a impunidade, a prevenção de futuras violações de direitos humanos, a reparação às vítimas, a retirada de governantes arbitrários do poder, o restabelecimento do Estado Democrático de Direito e a reafirmação do princípio da legalidade. Assim, o efeito da justiça retributiva, expressa por um julgamento criminal, é mais um aspecto de revelar ou construir a verdade dos acontecimentos passados, com efeito simbólico, visando à reconstrução da identidade cultural e moral de uma comunidade.

Quando se trata da verdade em caso de crimes internacionais, há mais interesses por trás de seu desvelamento que a mera declaração da culpa ou inocência do agente violador de direitos humanos. Isso porque ela está muito mais relacionada à justiça restaurativa que a retributiva. Não se trata, desse modo, de revelar a verdade para punir o culpado apenas, mas para saber os fatos, circunstâncias das violações de direitos, para que o tecido social possa se reconciliar. O direito à verdade deve, então, dividir os princípios e valores de um direito internacional penal, pois favorece a restauração e manutenção da paz, facilita o processo de reconciliação, contribui para a erradicação da impunidade, reconstrói a identidade nacional ${ }^{288}$, e possibilita uma construção de uma verdade histórica ou oficial a partir de um debate público, e não imposto por algum "vencedor".

Ademais, o direito à verdade assegura que a investigação dos crimes seja feita de forma transparente, e que seja conhecido os habeas corpus impetrados em caso de detenções de pessoas pelo Estado, assim como por meio do acesso público a documentos oficiais. Em razão de maior satisfação das vítimas nos lugares onde ocorreram julgamentos, a Comissão de Direitos Humanos adotou a Resolução 2005/66 que "reconhece a importância de respeitar e assegurar o direito à verdade como forma de contribuir para o fim da impunidade, e promover e proteger direitos humanos"289.

\footnotetext{
${ }^{287}$ TELES, Edson Luis de Almeida. Brasil e África do Sul: rupturas e continuidades nas transições políticas. In: SOARES, Inês Virgínia Prado e KISHI, Sandra Akemi Shimada. Memória e Verdade - A justiça de transição no Estado Democrático Brasileiro. Belo Horizonte: Fórum, 2009, p. 130.

${ }^{288}$ NAQVI, Yasmin. The right to the truth in international law: fact or fiction? In International Review of the Red Cross, vol. 88, n. 862, jun. 2006, p. 247.

${ }^{289}$ Idem, p. 248. Resolução: "recognizes the importance of respecting and ensuring the right to the truth so as to contribute to ending impunity and to promote and to protect human rights".
} 
Outra questão que prejudica diretamente a promoção do direito à verdade, diz respeito à aplicação da anistia quando ela exclui a possibilidade de julgar os perpetradores de graves violações de direitos humanos. Ela é proibida pelo Direito Internacional justamente porque impossibilita a verdade e a responsabilização dos culpados pelas violações. Nos casos em que a anistia é legítima ${ }^{290}$, como um recurso para a responsabilização e reconciliação, como instrumento de uma justiça restaurativa - a exemplo da África do Sul - a verdade assume um valor jurídico e não meramente moral ou individual ${ }^{291}$.

\subsection{Os casos de desaparecimento da Corte Interamericana de Direitos Humanos e o direito à verdade}

A partir da verificação de que o direito à verdade nasce da relação intrínseca dos familiares das vítimas de desaparecimento a saberem acerca do paradeiro de seu ente querido, cumpre analisar como os casos de desaparecimento forçado ocorridos em âmbito do Sistema Interamericano de Direitos Humanos são julgados, como a Corte entende esse direito, ou aprecia a questão da verdade. Ademais, também é objeto apropriado identificar o desenvolvimento da jurisprudência da Corte acerca dos casos de desaparecimento, considerando o grau protetivo em relação ao fenômeno, e as reparações determinadas por esse tribunal aos Estados que praticaram o desaparecimento forçado.

\subsubsection{A Corte Interamericana de Direitos Humanos e as Reparações em caso de graves violações de direitos humanos}

A Corte Interamericana de Direitos Humanos ${ }^{292}$ é composta por sete juízes cujo mandato é de seis anos, renovável por igual período. Os sete juízes são eleitos pelos Estados-Partes da Convenção, durante a Assembléia Geral da OEA. Não deve haver mais de um juiz da mesma nacionalidade na composição da Corte. Os sujeitos processuais que atuam perante a Corte são: a Comissão Interamericana de Direitos Humanos e os Estados. Depois de admitida a

\footnotetext{
${ }^{290}$ Cf. BASTOS, Lucia Elena Arantes Ferreira. Anistia - As leis internacionais e o caso brasileiro. Curitiba: Juruá, 2009.

${ }^{291}$ NAQVI, Yasmin. The right to the truth in international law: fact or fiction? In International Review of the Red Cross, vol. 88, n. 862, jun. 2006, p. 267.

292 http://www.corteidh.or.cr
} 
demanda pela Corte, as supostas vítimas, seus familiares ou seus representantes devidamente qualificados poderão apresentar seus argumentos e provas de forma autônoma durante o processo. Em caráter de exceção, admite-se a participação do indivíduo na fase processual que estipula a reparação devida.

Quanto às jurisdições da Corte, podem ser consultiva ou contenciosa. Qualquer Estadomembro da OEA, mesmo que não faça parte da Convenção Americana de Direitos Humanos, pode pleitear o parecer da Corte no que diz respeito à interpretação da própria Convenção ou de qualquer outro tratado internacional vinculado à proteção dos direitos humanos no âmbito dos Estados americanos. A Corte também tem competência para analisar casos referentes à compatibilidade de preceitos da legislação interna em face dos instrumentos internacionais. Também os órgãos da OEA poderão, respeitando as suas esferas de competência, solicitar o parecer consultivo da Corte.

Em relação à jurisdição contenciosa, a Corte é competente para o julgamento de casos propriamente ditos. Somente podem solicitar este tipo de jurisdição os Estados-Partes da Convenção, e que tenham reconhecido tal jurisdição, que é apresentada sob a forma de cláusula facultativa. Na jurisdição contenciosa, a decisão da Corte tem força vinculante e obrigatória. Nos casos em que a Corte determina uma indenização à vítima, tal decisão vale como título executivo, devendo a vítima seguir com os procedimentos internos relativos à execução de sentença desfavorável ao Estado consoante a sua legislação local.

A natureza objetiva das obrigações de proteção de direitos humanos consagra o indivíduo como principal preocupação da responsabilidade internacional do Estado por violação de direitos humanos. A responsabilidade internacional tem sido reconhecida como sendo um princípio geral do Direito Internacional, qual seja, a violação de normas internacionais atribuível a um Estado gera responsabilidade internacional e o conseqüente dever de reparação. ${ }^{293}$ Verifica-se também que, quando os tratados de direitos humanos referem-se ao dever do Estado de garantir os direitos declarados, não mencionam o elemento "culpa" para caracterizar a responsabilidade internacional do Estado. Para o Direito Internacional dos Direitos Humanos, o Estado tem a responsabilidade primária em relação à proteção de

293 RAMOS, André. Responsabilidade Internacional por violação de Direitos Humanos: seus elementos, a reparação devida e as sanções possíveis: teoria e prática. Rio de Janeiro: Renovar, 2004, capítulo 2. 
direitos, tendo a comunidade internacional a responsabilidade subsidiária, quando as instituições nacionais se mostram falhas ou omissas na proteção de direitos.

Nesse sentido, André de Carvalho Ramos ${ }^{294}$ considera que a responsabilidade do Estado consolidou-se no Direito Internacional graças a uma série de casos internacionais que atestaram a existência de um princípio de Direito Internacional reconhecido pelos Estados de responsabilização e reparação de fatos internacionalmente ilícitos. A questão considerada é que o regime da responsabilidade internacional do Estado foi ampliado para proteger as pessoas contra os arbítrios de um Estado. Esta vertente veio a se constituir no precedente direto do atual regime de proteção internacional dos direitos humanos. Contudo, este regime ainda não foi codificado em nenhum instrumento internacional. O que existe é um projeto de Convenção sobre Responsabilidade Internacional do Estado, de 2001, no âmbito do Conselho de Direito Internacional da ONU.

Importante assinalar, ainda, a obrigação de reparação consagrado no o artigo 63.1 da Convenção Americana de Direitos Humanos, contendo previsão acerca da responsabilidade internacional do Estado e da conseqüente reparação aos danos causados. O Estado-Parte violador tem o dever de assegurar uma reparação adequada dos danos causados à vítima e a seus familiares. Caso isso não ocorra, o Estado também estaria incorrendo em responsabilidade internacional.

Nesse âmbito, é válido ressaltar que os Estados-Parte da OEA, ao ratificarem a Convenção, codificaram o princípio de Direito Internacional de que a declaração de responsabilidade internacional gera o dever de reabilitar a situação anterior à violação do direito, quando possível, e reparar os danos causados com a violação. Segundo a Corte Interamericana de Direitos Humanos, essa reparação se rege pelo Direito Internacional - e não pelo direito interno - em todos os seus aspectos: alcance, natureza, modalidades e determinação dos seus beneficiários.

Por reparação entenda-se toda e qualquer conduta do Estado infrator para eliminar as conseqüências do fato internacionalmente ilícito, o que compreende uma série de atos, inclusive as garantias de não-repetição. Com isso, o retorno ao status quo ante é a essência da reparação, mas não exclui outras fórmulas de reparação do dano causado. ${ }^{295}$

${ }^{294}$ Idem, p. 71.

${ }^{295}$ Idem, p. 245. 
A Corte deixou clara, assim, a especificidade da reparação devida pela violação de normas da Convenção; trata-se de um procedimento internacional de reparação a graves violações de direitos humanos, e não de uma simples ação de danos e prejuízos de direito civil interno. Nesse sentido, a Corte declarou que as insuficiências do direito interno não poderiam constituir obstáculo para a aplicação das distintas modalidades de reparação reconhecidas pelo Direito Internacional.

A Corte considera, em suas modalidades de reparação ${ }^{296}$, a restituição na íntegra, que permite o retorno ao status quo ante pela completa eliminação da conduta violadora e seus efeitos; a reparação do projeto de vida, pela reparação do dano emergente e dos lucros cessantes - como projeto de vida entende-se o conjunto de opções que o indivíduo pode ter para conduzir sua vida e alcançar o destino para o qual ele se propõe -; a restituição material e jurídica, sendo que, a material diz respeito à devolução de bens ou pessoas ilicitamente detidos, e a jurídica consiste na necessidade de alteração de normas de direito interno para obter restituição na íntegra; a declaração de ilicitude, manifestação de pesar e desculpas, por meio de atos simbólicos de reconhecimento da ilicitude da sua conduta; o pagamento de somas simbólicas; a indenização, pois quando não puder voltar à situação anterior o Estado deve indenizar a vítima pecuniariamente, diferindo-se do dano moral, que advém obrigatoriamente da violação aos citados direitos; as garantias de não-repetição e de investigação etc.

Com a ação internacional, verifica-se uma maior visibilidade das violações de direitos humanos, desencadeando o risco do constrangimento político e moral ao Estado infrator. Isso tem permitido alguns avanços na proteção dos direitos humanos. Ao enfrentar a publicidade das violações de direitos humanos, o Estado é praticamente obrigado a se justificar acerca das suas práticas, o que tem auxiliado na modificação ou na melhoria de uma determinada prática governamental, conferindo suporte ou estímulo para alterações internas, e mudanças políticas, no sentido de adequá-las às bases determinadas pelo Direito Internacional dos Direitos Humanos. O sistema internacional invoca um parâmetro de ação para os Estados, legitimando o encaminhamento de denúncias se as obrigações internacionais são desrespeitadas. Neste sentido, a sistemática internacional estabelece a tutela, a supervisão e o monitoramento do modo pelo qual os Estados garantem os direitos humanos internacionalmente tutelados. ${ }^{297}$

\footnotetext{
${ }^{296}$ Idem, pp. 245-312. Ver também artigos 209-11 da Convenção Americana de Direitos Humanos.

${ }^{297}$ BOBBIO, Norberto. A era dos direitos. Rio de Janeiro: Campus, 1992.
} 


\subsubsection{Os casos da Corte Interamericana de Direitos Humanos de desaparecimento forçado de pessoas e o direito à verdade}

Os casos analisados por esta dissertação são aqueles de desaparecimento forçado de pessoas julgados pela Corte Interamericana de Direitos Humanos. A busca dos casos foi feita duas vezes, nas datas 31 de maio de 2009 e confirmada na data 30 de janeiro de 2010. Como a busca avançada do site com palavras-chave não é confiável, haja vista os resultados aparecerem sempre diversos, apesar do uso das mesmas palavras, o levantamento dos casos foi feito um a um, a partir da leitura dos fatos de cada caso contencioso julgado por esta Corte $^{298}$. Apesar de a busca ter sido feita de forma manual, sem confiar nos instrumentos de busca disponibilizados no sítio, é possível que algum caso tenha sido deixado de fora da análise, em decorrência da dificuldade de identificar a totalidade dos casos de desaparecimento forçado apreciados por essa Corte. O julgamento acerca da confiabilidade das ferramentas de busca depreende-se do fato de que o sistema de busca avançada ${ }^{299}$, a despeito de se utilizar as palavras-chave desaparición, desaparición y forzada, ou desaparición y forzada y de y personas, parece efetuar a busca em todas as sentenças, de modo que aparecem como resultados quaisquer casos em que haja menção a essas palavras. Por essa razão, optou-se por ler os fatos de cada caso contencioso disponibilizado, nas datas mencionadas, a fim de identificar quais eram casos de desaparecimento forçado de pessoas.

Os casos contenciosos julgados pela Corte de desaparecimento forçado de pessoas, e disponibilizados no sítio, na data 30 de janeiro de 2010, são os seguintes ${ }^{300}$ :

Velásquez Rodríguez vs. Honduras

Godínez Cruz vs. Honduras

Fairén Garbi e Solís Corrales vs. Honduras

Neira Alegría vs. Peru

Caballero Delgado e Santana vs. Colômbia

Blake vs. Guatemala

"Panel Blanca" (Paniagua Morales e outros) vs. Guatemala

Trujillo Oroza vs. Bolívia

Durand e Ugarte vs. Peru

Bámaca Velásquez vs. Guatemala

Caracazo vs. Venezuela

\footnotetext{
${ }^{298}$ Sítio em que se encontram os casos contenciosos julgados pela Corte: http://www.corteidh.or.cr/casos.cfm. ${ }^{299} \mathrm{http}$ ://www.corteidh.or.cr/buscadores.cfm

300 Todos os casos contenciosos julgados pela Corte e disponibilizados no sítio eletrônico do órgão, na data 30 de janeiro de 2010, encontram-se listados no Anexo.
} 
Juan Humberto Sánchez vs. Honduras

Molina Theissen vs. Guatemala

19 Comerciantes vs. Colômbia

Irmãs Serrano Cruz vs. El Salvador

"Masacre de Mapiripán" vs. Colômbia

Gómez Palomino vs. Peru

Blanco Romero e outros vs. Venezuela

Goiburú e outros vs. Paraguai

La Cantuta vs. Peru

Heliodoro Portugal vs. Panamá

Tiu Tojín vs. Guatemala

Ticona Estrada e outros vs. Bolívia

Anzualdo Castro vs. Peru

O primeiro caso julgado pela Corte em 29 de julho de 1988, Velásquez Rodríguez vs. Honduras $^{301}$, refere-se a uma situação de desaparecimento forçado de pessoas, encaminhado pela Comissão de Direitos Humanos na data 24 de abril de 1986. Esta Comissão pediu a apreciação da Corte em relação à violação dos arts. 4, 5 e 7 da Convenção Americana de Direitos Humanos pelo Estado de Honduras, contra o senhor Velasquéz Rodríguez, que condenou o Estado hondurenho a pagar justa indenização compensatória aos familiares do desaparecido, face à violação dos artigos citados. Em 20 de janeiro de 1989 a Corte julgou mais um caso hondurenho de desaparecimento forçado, Godínez Cruz vs. Honduras ${ }^{302}$, encaminhado pela Comissão de Direitos Humanos na mesma data que o primeiro caso, invocando as violações dos mesmos direitos da Convenção, e condenando da mesma forma o Estado em questão.

A compreensão dessa justa indenização está atrelada também aos danos morais causados aos familiares, além dos materiais, ou seja, a partir de um exame psicológico ${ }^{303}$, a Corte fixou um

301 A vítima em questão, estudante da Universidade Autônoma de Honduras foi preso de maneira violenta sem ordem judicial, por membros da Direção Nacional de Investigação e do G-2 das Forças Armadas de Honduras, em Tegucigalpa, no dia 12 de setembro de 1981. Diversas testemunhas oculares denunciaram que ele foi levado às celas da II Estação da Força de Segurança Pública, onde foi submetido a duros interrogatórios, e que, apesar disso, todos os corpos policiais e de segurança negaram sua detenção. Caso Velasquéz Rodríguez vs. Honduras, sentença de mérito, p. 2, para. 3.

302 O senhor Godínez Cruz desapareceu no dia 22 de julho de 1982, quando saiu de casa para o trabalho onde exercia a função de professor em Monjáras de Choluteca. Ele foi detido por um homem com vestes militares acompanhado por pessoas vestidas de civil, de acordo com um testemunho, e levado por eles em um carro sem placa. De acordo com vizinhos, sua casa estava sendo vigiada, dias anteriores ao seu desaparecimento. Caso Godinez vs. Honduras, sentença de mérito, p. 1, para. 2.

303 Caso Godinez vs. Honduras, sentença de reparações e custas, p. 11, para. 49. Los daños morales están demostrados en los documentos periciales y en la declaración rendida por el doctor en Psiquiatría Federico Allodi, profesor de Psicología en la Universidad de Toronto, Canadá. Según tal declaración el mencionado 
valor correspondente a tal dano. No pedido da família e seus representantes, aparece o pedido de declaração pública do cometimento de desaparecimento pelo Estado, e a homenagem à vítima por meio de memoriais, compondo o rol de reparações éticas demandadas pela vítima $^{304}$. Quanto à menção da Corte acerca da obrigação do Estado de buscar a verdade, ela é bastante clara ao apontar sua eventual responsabilidade internacional caso os resultados da investigação não sejam satisfatórios, relacionando o direito dos familiares das vítimas de saberem a sorte dos desaparecidos bem como de encontrarem seus restos mortais. ${ }^{305}$

Em 15 de março de 1989, a Corte apreciou o caso de desaparecimento de Fairén Garbi e Solís Corrales vs. Honduras ${ }^{306}$, encaminhado pela Comissão na mesma data que os anteriores. Entendeu esse tribunal, contudo, que não havia prova suficiente de que os desaparecimentos foram cometidos pelo Estado hondurenho, pois a Comissão fundamentou sua denúncia exclusivamente no fato de a prática de desaparecimentos ser corrente no país à época, de modo que Honduras não foi declarado responsável neste caso.

doctor realizó exámenes a la esposa de Saúl Godínez Cruz, señora Enmidida Escoto de Godínez y a la niña Emma Patricia Godínez Escoto. En tales exámenes aparece que sufrían de diversos síntomas de sobresalto, angustia, depresión y retraimiento, todo ello con motivo de la desaparición del padre de familia. El Gobierno no pudo desvirtuar la existencia de problemas psicológicos que afectan a los familiares de la víctima. La Corte considera evidente que, como resultado de la desaparición de Saúl Godínez Cruz, se produjeron consecuencias psíquicas nocivas en sus familiares inmediatos, las que deben ser indemnizadas bajo el concepto de daño moral. ${ }^{304}$ Caso Godinez vs. Honduras, sentença de reparações e custas, pp. 4-5, para. 7, (6), para. 9.

305 Caso Godinez vs. Honduras, sentença de mérito, p. 31, para. 177: En ciertas circunstancias puede resultar difícil la investigación de hechos que atenten contra derechos de la persona. La de investigar es, como la de prevenir, uma obligación de medio o comportamiento que no es incumplida por el solo hecho de que la investigación no produzca un resultado satisfactorio. Sin embargo, debe emprenderse con seriedad y no como una simple formalidad condenada de antemano a ser infructuosa. Debe tener un sentido y ser asumida por el Estado como un deber jurídico propio y no como una simple gestión de intereses particulares, que dependa de la iniciativa procesal de la víctima o de sus familiares o de la aportación privada de elementos probatorios, sin que la autoridad pública busque efectivamente la verdad. Esta apreciación es válida cualquiera sea el agente al cual pueda eventualmente atribuirse la violación, aun los particulares, pues, si sus hechos no son investigados con seriedad, resultarían, en cierto modo, auxiliados por el poder público, lo que comprometería la responsabilidad internacional del Estado.

No mesmo sentido, p. 38, para. 181. El deber de investigar hechos de este género subsiste mientras se mantenga la incertidumbre sobre la suerte final de la persona desaparecida. Incluso en el supuesto de que circunstancias legítimas del orden jurídico interno no permitieran aplicar las sanciones correspondientes a quienes sean individualmente responsables de delitos de esta naturaleza, el derecho de los familiares de la víctima de conocer cuál fue el destino de ésta y, en su caso, dónde se encuentran sus restos, representa una justa expectativa que el Estado debe satisfacer con los medios a su alcance.

$\mathrm{Na}$ sentença de reparação há a seguinte menção na p. 10, para. 34: No obstante la Corte ya señaló en su sentencia sobre el fondo, la subsistencia del deber de investigación que corresponde al Gobierno, mientras se mantenga la incertidumbre sobre la suerte final de la persona desaparecida. A este deber de investigar se suma el deber de prevenir la posible comisión de desapariciones forzadas y de sancionar a los responsables directos de las mismas.

306 Ambos os desaparecidos Fairén Garbi, estudante e funcionário público, e Solís Corrales, professora, eram costa-riquenhos, e desapareceram em Honduras, no dia 11 de dezembro de 1981, quando viajavam pelo país em direção ao México. As autoridades hondurenhas negaram a estada dos dois no país, mas o governo da Nicarágua apresentou comprovações de que eles estavam naquele país quando desapareceram. Caso Fairén Garbi e Solís Corrales vs. Honduras, sentença de mérito, p. 1, para. 3, 3. 
Os casos seguintes de desaparecimento julgados pela Corte, em 1995, foram Neira Alegría vs. Peru $^{307}$, cuja sentença de mérito é de 19 de janeiro, e Caballero Delgado e Santana vs. Colômbia $^{308}$, sentença de 8 de dezembro. O primeiro caso foi apresentado pela Comissão em 10 de outubro de 1990, e alegou a violação dos arts. 1, 5, 4, 7, 25 e 27, da Convenção Americana por parte do Estado peruano, enquanto o segundo foi encaminhado no dia 24 de dezembro de 1992, com fundamento de violação aos arts. 1, 2, 4, 5, 7, 8 e 25 do mesmo tratado. A Corte entendeu ter havido violação aos arts. 4, 7 e 27, pelo Peru, no caso Neira Alegría, e aos arts. 2, 8 e 25, no Caballero Delgado e Santana, pela Colômbia.

Quanto às justas indenizações compensatórias, determinadas pela Corte em ambos os casos, em Neira Alegría vs. Peru, a Corte determinou um montante referente a danos materiais e morais, bem como poupanças aos menores de idade das três famílias correspondentes aos desaparecidos, e ordenou, na sentença de reparação e custas, que o "Estado do Peru está obrigado a fazer todo o esforço possível para localizar e identificar os restos das vítimas e entregá-los a seus familiares" ${ }^{309}$. No caso colombiano, a Corte decidiu pelos mesmos termos fixar a indenização material e moral aos familiares das vítimas, assim como localizar seus restos mortais ${ }^{310}$. A Comissão Interamericana havia solicitado, contudo, a necessidade da reforma da legislação colombiana em relação ao habeas corpus e a tipificação do crime de desaparecimento, constituindo reparações não pecuniárias a este caso ${ }^{311}$. Apesar disso, a consideração daquele órgão não foi mencionada na sentença expedida pela Corte.

\footnotetext{
${ }^{307}$ No dia 18 de junho de 1986 Neira Alegría, Edgar Escobar e William Escobar encontravam-se presos em um estabelecimento penal San Juan Bautista, e estavam sendo processados por terrorismo. Logo após um motim, e conseqüente ação das forças armadas, essas três pessoas desapareceram, sem que seus familiares tivessem mais notícias deles. Caso Neira Alegría vs. Peru, sentença de mérito, p. 1, para. 3.

${ }^{308}$ Caballero Delgado e María Santana foram capturados por uma patrulha militar formada por unidades do exército da Colômbia, em 7 de fevereiro de 1989, em razão da participação ativa do Sr. Delgado como dirigente sindical dos professores, durante 11 anos, sendo constantemente ameaçado desde 1986, quando esteve preso por porte ilegal de armas. A Sra. Santana também pertencia ao movimento 19 de Abril (M-19), e colaborava com o Sr. Delgado na mobilização popular, na época com vistas à realização do Encontro pela Convivência e Normalização. Caso Caballero Delgado e Santana vs. Colômbia, sentença de mérito, p. 2, para. 3.

309 Caso Neira Alegría vs. Peru, sentença de reparação e custas, p. 15, 4) Decide que el Estado del Perú está obligado a hacer todo el esfuerzo posible para localizar e identificar los restos de las víctimas y entregarlos a sus familiares.

${ }^{310}$ Caso Delgado Caballero vs. Colômbia, sentença de reparação e custas, p. 16, 4) Que el Estado de Colombia está obligado a continuar los esfuerzos para localizar los restos de las víctimas y entregarlos a sus familiares.

311 Caso Delgado Caballero vs. Colômbia, sentença de reparação, p. 13, para. 53. En cuanto a reparaciones no pecuniarias la Comisión solicitó la reforma de la legislación colombiana respecto del recurso de hábeas corpus, la tipificación legislativa del delito de desaparición forzada de personas y que los procedimientos judiciales sobre la desaparición de Isidro Caballero Delgado y María del Carmen Santana permanezcan en la competencia de la justicia ordinaria y no Sean transferidos al fuero militar.
} 
Em 3 de agosto de 1995 a Comissão submeteu à Corte Interamericana o caso Blake vs. Guatemala $^{312}$, com o fim de verificar se houve violação aos arts. 4, 7, 8, 13, 22 e 25 da Convenção Americana de Direitos Humanos. Apesar de seu aparecimento mais de 7 anos depois, o Estado não havia cumprido as recomendações da Comissão, motivo porque se justificava a interposição do caso junto à Corte. Havia também a questão relativa à competência ratione temporis da Corte para julgar, já que a violação de tais direitos ocorreu em 1985 - e Guatemala aceitou a jurisdição da Corte em 1987 -, mas este tribunal internacional considerou-se competente em suas exceções preliminares, em razão do caso em questão ser de violação continuada de direitos humanos até 1992, quando o corpo foi encontrado ${ }^{313}$.

312 O caso em questão apresenta uma situação diversa dos casos anteriormente apreciados pela Corte, em razão da localização do Sr. Blake sete anos depois de seu desaparecimento. Assim, jornalista estadunidense, enquanto recolhia material acerca da guerrilha guatemalteca, foi seqüestrado em 28 de março de 1985 e assassinado por agentes do Estado, e seu desaparecimento perdurou até 14 de junho de 1992. Este caso inaugura um debate no âmbito da Corte em razão da natureza do desaparecimento forçado de pessoas e sua tutela, haja vista sua recente definição pela Convenção Interamericana de Direitos Humanos. Caso Blake vs. Guatemala, sentença de mérito, voto arrazoado juiz Cançado Trindade, pp. 3-4, paras. 7-9:

7. Por un lado, nos vemos aquí ante un caso comprobado de desaparición forzada de persona, tipificada inclusive en el Código Penal guatemalteco vigente (artículo 201 ter reformado) como delito continuado. En el mismo sentido, la normativa internacional de protección la tipifica como un delito "continuado o permanente mientras no se establezca el destino o paradero de la víctima” (Convención Interamericana sobre Desaparición Forzada de Personas de 1994, artículo III); además, advierte que se trata de un delito específico y autónomo, que constituye una forma compleja de violación de los derechos humanos (con hechos delictivos conexos), y que por eso requiere que sea comprendido y encarado de una manera necesariamente integral (como se desprende del preámbulo y de los artículos IV y II de aquella Convención).

8. Por otro lado, en virtud de que Guatemala, como Estado Parte en la Convención Americana sobre Derechos Humanos (desde el 25 de mayo de 1978), solo aceptó la competencia de la Corte Interamericana en materia contenciosa el 09 de marzo de 1987, somos llevados, por la aplicación de un postulado rígido del derecho de los tratados, a introducir una fragmentación artificial en la consideración de aquel delito de desaparición forzada, tomando en cuenta - de forma atomizada y no integral -solamente algunos elementos componentes del mismo, con posterioridad a esta última fecha, - con consecuencias directas para la etapa de reparaciones.

9. Dicha situación es, a mi modo de ver, insatisfactoria y preocupante, por tratarse la desaparición forzada de persona, primero, de una forma compleja de violación de los derechos humanos; segundo, de una violación particularmente grave; y tercero, de una violación continuada o permanente (hasta que se establezca El destino o paradero de la víctima). En efecto, la situación continuada (cf. infra) es manifiesta en el delito de desaparición forzada de personas.

Caso Blake vs. Guatemala, sentença de reparação, voto arrazoado juiz Cançado Trindade, p. 1, para. 3:

La tragedia jurídica - tal como la veo - del presente caso Blake reside en que, por la aplicación de un postulado clásico del derecho de los tratados, se desfiguró y fragmentó indebidamente el delito de desaparición forzada de personas, con claras repercusiones en la presente Sentencia de reparaciones. Esto ocurre a pesar de todos los esfuerzos que resultaron en la reciente tipificación, a nivel internacional, de dicha desaparición como un delito "continuado o permanente mientras no se establezca el destino o paradero de la víctima" (Convención Interamericana sobre Desaparación Forzada de Personas de 1994, artículo III), como una forma compleja de violación de los derechos humanos (con hechos delictivos conexos) a ser comprendido de modo necesariamente integral (a la luz de los artículos IV y II, y preámbulo, de aquella Convención).

${ }^{313}$ Caso Blake vs. Guatemala, sentença de mérito, p. 24, paras. 53-5:

53. Antes de entrar al fondo del presente caso, la Corte considera necesario retomar el examen de la cuestión previa de la limitación ratione temporis de su competencia. En la sentencia sobre excepciones preliminares dictada el 2 de julio de 1996 la Corte resolvió que la privación de la libertad y la muerte del señor Nicholas 
Quanto à decisão de mérito, proferida na data 24 de janeiro de 1998, a Corte decidiu que o Estado da Guatemala violou as garantias judiciais em prejuízo dos familiares do Sr. Blake, que durante sete anos buscaram por seu ente desaparecido, além de tê-los causado danos relativos à integridade psíquica e moral ${ }^{314}$. Determinou também que a Guatemala é responsável por investigar as violações e punir os culpados pela morte e desaparecimento da vítima em tela. Ademais, condenou o Estado a pagar justa indenização compensatória aos familiares, e a ressarci-los por todos os gastos com os anos de busca. ${ }^{315}$

Também no ano de 1998, em 8 de março, a Corte Interamericana emitiu sentença de mérito no caso "Panel Blanca" (Paniagua Morales e outros) vs. Guatemala ${ }^{316}$, introduzido a esse tribunal pela Comissão no dia 19 de janeiro de 1995, sob alegação de violação dos arts. 1 - de todas as vítimas, 4, 5, 7 - de algumas vítimas, 8 e 25 - de todas as vítimas, todos da Convenção Americana, além dos arts. 1, 6 e 8 - de algumas vítimas da Convenção

Blake se consumaron en marzo de 1985, que dichos hechos no podían considerarse per se de carácter continuado y que el Tribunal carecía de competencia para decidir la responsabilidad del Estado respecto de los mismos.

54. La Corte en la sentencia citada anteriormente, indicó además que, si bien algunos de los hechos ya se consumaron, sus efectos podían prolongarse de manera continua o permanente hasta el momento en que se establezca el destino o paradero de la víctima. Como en este caso el destino o paradero del señor Nicholas Blake no se conoció hasta el 14 de junio de 1992, con posterioridad a la fecha en que Guatemala reconoció la jurisdicción contenciosa de este Tribunal, éste estimó que tiene competencia para conocer de las posibles violaciones que le imputa la Comisión al Estado en cuanto a dichos efectos y conductas.

55. La Comisión señaló, en el escrito de alegatos finales, que si bien es cierto que en la sentencia sobre excepciones preliminares la Corte decidió, por tratarse en la especie de una desaparición forzada, que sus efectos se extienden hasta la fecha em que se produzca el completo esclarecimiento de la misma y que la desaparición forzada subsiste como un todo indivisible por tratarse de un delito continuado o permanente, más allá de la fecha en que se produjo la muerte, siempre y cuando la misma se haya producido en el marco de una desaparición forzada. En el presente caso, las autoridades guatemaltecas, además de saber que el señor Nicholas Blake había sido secuestrado y desaparecido, también sabían que había sido asesinado. Agregó que la obstrucción de la justicia no sólo estaba dirigida a impedir una investigación y afectar el debido proceso, sino también a ocultar el paradero del señor Nicholas Blake y que, por consiguiente, dichas actuaciones afectaron el derecho a la vida consagrado en el artículo 4 de la Convención Americana.

${ }^{314}$ Caso Blake vs. Guatemala, sentença de mérito, voto arrazoado do juiz Cançado Trindade, p. 12, para. 38: En una situación continuada propia de la desaparición forzada de persona, las víctimas son tanto el desaparecido (víctima principal) como sus familiares; la indefinición generada por la desaparición forzada sustrae a todos de la protección del derecho. No hay cómo negar la condición de víctimas también a los familiares del desaparecido, que tienen el cotidiano de sus vidas transformado en un verdadero calvario, en el cual los recuerdos del ser querido se mezclan con el tormento permanente de su desaparición forzada. En mi entender, la forma compleja de violación de múltiples derechos humanos que representa el delito de desaparición forzada de persona tiene como consecuencia la ampliación de la noción de víctima de violación de los derechos protegidos.

Caso Blake vs. Guatemala, sentença de reparação, voto arrazoado do juiz Cançado Trindade, p. 16, para. 45:

(...) Décima, las víctimas, así entendidas, que forman la parte lesionada en el contencioso internacional de los derechos humanos, son, en conclusión, sujetos del Derecho Internacional de los Derechos Humanos, dotados tanto de personalidad como de plena capacidad jurídicas internacionales.

${ }^{315}$ Caso Blake vs. Guatemala, sentença de mérito, p. 38, para. 124.

${ }^{316}$ Entre 1987 e 1988 o Estado da Guatemala cometeu atos de seqüestro, detenção arbitrária, trato inumano, tortura e assassinato contra 11 pessoas, caso que ficou conhecido como da "Panel blanca". 
Interamericana para Prevenir e Sancionar a Tortura ${ }^{317}$. Neste caso surge nos testemunhos dos familiares das vítimas o discurso de saber a verdade, como modo de apaziguar seu sofrimento $^{318}$. A Corte condenou o Estado guatemalteco nas violações denunciadas pela Comissão, exigindo a reparação por meio de justa indenização compensatória, além da obrigação de o Estado "realizar uma investigação real e efetiva para determinar as pessoas responsáveis pelas violações aos direitos humanos que a sentença faz referência e, eventualmente, sancioná-las",319.

No ano de 2000, em 26 de janeiro, a Corte emitiu sua sentença de mérito ao caso Trujillo Oroza vs. Bolívia ${ }^{320}$, a partir da demanda da Comissão, enviada ao tribunal na data de 9 de junho de 1999, sob alegação de violação aos arts. 1.1, 3, 4, 5.1 e 5.2, 7, 8.1, 25, do desaparecido e dos seus familiares, pelo Estado boliviano. A Corte determinou a responsabilidade internacional da Bolívia em relação aos artigos denunciados pela Comissão, e reconheceu a contribuição desse Estado para o desenvolvimento dos direitos humanos, em função de ter assumido a responsabilidade pelos fatos ocorridos ${ }^{321}$.

Na sentença de reparação e custas deste caso, pela primeira vez em casos de desaparecimento forçado de pessoas, a Corte se manifestou de maneira tão incisiva em relação às reparações simbólicas, apontando que somente o fato de o Estado ter assumido a responsabilidade pela

317 Caso "Panel Blanca" (Paniagua Morales e outros) vs. Guatemala, sentença de mérito, p. 1, para. 1.

318 Caso "Panel Blanca" (Paniagua Morales e outros) vs. Guatemala, sentença de mérito, p. 18, para. 65: Testemunho de Miriam Enoé Zelada Chinchilla, irmã de Erick Leonardo Chinchilla: La familia todavía siente temor de represalias por parte de las autoridades por rendir testimonio ante la Corte Interamericana y por querer "saber la verdad para limpiar El honor" de su familiar.

No mesmo sentido, perita Graciela Marisa Guilis, psicóloga, especialista em saúde mental e violações de direitos humanos do Centro de Estudios Legales y Sociales en Buenos Aires, sobre o testemunho de Manuel Alberto González Chinchilla, p. 24, para. 66: La familia le transmitió una imagen paterna buena, con la que Manuel Alberto decidió identificarse. En su caso, resulta positiva la existencia de condiciones favorables que permiten un desarrollo saludable. Asimismo, elementos como conocer la verdad y que se haga justicia en su situación, resultarían muy positivos en su progreso psicológico. Finalmente, manifestó que la denegación de justicia y la impunidad afectan El psiquismo de las personas y agudiza el miedo de los familiares, especialmente a que la situación se repita en su núcleo familiar. De manera que "siempre la verdad y la justicia ayudan a cicatrizar esas heridas, [aunque] no las borran".

319 Caso "Panel Blanca" (Paniagua Morales e outros) vs. Guatemala, sentença de mérito, p. 76, para. 181, 6) Declara que el Estado de Guatemala debe realizar una investigación real y efectiva para determinar las personas responsables de las violaciones a los derechos humanos a que se ha hecho referencia en esta Sentencia y, eventualmente, sancionarlas.

${ }^{320}$ Caso Trujillo Oroza vs. Bolívia, sentença de mérito, p. 2, para. 2. Em 23 de dezembro de 1971 o Sr. Trujillo Oroza, estudante da Universidade Mayor de San Andrés foi detido sem ordem judicial. Sua mãe passou a visitálo todos os dias até o dia 2 de fevereiro de 1972, quando a vítima havia sido levada do estabelecimento prisional onde se encontrava, e nunca mais apareceu. Apesar de todas as medidas judiciais encaminhadas por seus familiares, somente em 8 de janeiro de 1999 o Estado passou a investigar.

${ }^{321}$ Caso Trujillo Oroza vs. Bolívia, sentença de mérito, p. 10-1, paras. 36-43. 
violação dos direitos da Convenção, já era motivo de reparação e satisfação aos familiares da vítima. Além disso, a Corte estipulou a publicação de sua sentença no Diário Oficial, com o desenvolvimento legislativo interno para tipificar o crime de desaparecimento. E, de acordo com a iniciativa da Bolívia, estimulou o país acerca da idéia de dar o nome da vítima a uma escola, de modo a preservar a memória do desaparecido. Essas reparações, contudo, não prejudicam a obrigação de o Estado localizar os restos da vítima, e entregá-los à família, para que possam fazer seu sepultamento dignamente. ${ }^{322}$ Nesta sentença a Corte passa a dar indícios de sua abordagem em relação à importância da verdade como medida reparatória aos familiares do desaparecido mais incisivamente, e afirma que o fato de devolver os restos do desaparecido à família, para fazer o sepultamento dignamente, constitui ato de justiça e forma de reparação ${ }^{323}$.

${ }^{322}$ Caso Trujillo Oroza vs. Bolívia, sentença de reparação e custas, pp. 39-40, paras. 118-122; p. 44, para. 141.

${ }^{323}$ Caso Trujillo Oroza vs. Bolívia, sentença de reparação e custas, pp. 37-8, paras. 108-9:

108. Esta sentencia constitucional, la cual constituye un aporte positivo al presente proceso, solucionó el problema que causaba el hecho de que se hubiese declarado prescrita la causa penal que se seguía en contra de los presuntos responsables de los hechos del presente caso. En consecuencia, al resolverse el problema de la prescripción, no debe existir impedimento alguno para que los familiares de la víctima conozcan la verdad de lo acaecido a José Carlos Trujillo Oroza y que se investigue y sancione a los responsables de los acontecimientos objeto del presente caso.

109. Como ha señalado este Tribunal, sólo si se esclarecen todas las circunstancias en cuanto a la violación, el Estado habrá proporcionado a las víctimas y a sus familiares un recurso efectivo y habrá cumplido con su obligación general de investigar y sancionar, permitiendo a los familiares de la víctima conocer la verdad, no sólo sobre el paradero de sus restos mortales sino sobre todo lo sucedido con la víctima.

Sentença de reparação e custas, pp.38-9, paras. 112-7:

112. En relación con la solicitud de investigación sobre el paradero de José Carlos Trujillo Oroza y la devolución de sus restos mortales, es importante mencionar que la Corte tuvo por demostrado en la sección relativa al daño inmaterial, que El desconocimiento del paradero de los restos mortales del señor Trujillo Oroza y la impunidad que subsiste en este caso han causado y continúan causando um sufrimiento intenso a sus familiares.

113. Sobre el particular, esta Corte ha señalado en reiteradas ocasiones que asiste a los familiares el derecho a conocer dónde se encuentran los restos mortales de su ser querido, y ha establecido que ello "representa una justa expectativa que El Estado debe satisfacer con los medios a su alcance".

114. La privación continua de la verdad acerca del destino de un desaparecido constituye una forma de trato cruel, inhumano y degradante para los familiares cercanos. El derecho a la verdad ha sido desarrollado suficientemente en el Derecho Internacional de los Derechos Humanos y como sostuvo esta Corte em anteriores oportunidades, el derecho de los familiares de la víctima de conocer lo sucedido a ésta y, en su caso, dónde se encuentran sus restos mortales, constituye una medida de reparación y por tanto una expectativa que el Estado debe satisfacer a los familiares de la víctima y a la sociedad como un todo.

115. En este sentido la Corte considera que la entrega de los restos mortales em casos de detenidosdesaparecidos es un acto de justicia y reparación en sí mismo. Es un acto de justicia saber el paradero del desaparecido, y es una forma de reparación porque permite dignificar a las víctimas, ya que los restos mortales de una persona merecen ser tratados con respeto para con sus deudos y con el fin de que éstos puedan darle una adecuada sepultura.

116. La Corte ha valorado las circunstancias del presente caso, particularmente la continua obstrucción a los esfuerzos de los padres y hermanos de la víctima de conocer la verdad de los hechos y encontrar el paradero de José Carlos, debido a diversos impedimentos de hecho y derecho por parte del Estado, tales como la falta de tipificación del delito de desaparición forzada, la negativa de diversas autoridades públicas de brindar información que no fuera contradictoria, y la omisión, durante 30 años, de realizar una investigación efectiva. 
Em 16 de agosto de 2000, a Corte julgou o caso Durand e Ugarte vs. Peru ${ }^{324}$, encaminhado pela Comissão no dia 8 de agosto de 1996, alegando que o Estado do Peru havia violado os arts. 1.1, 2, 4, 1.6, 8.1, 25.1, 27.2 da Convenção, em prejuízo dos Srs. Durand e Ugarte, de modo que a Corte entendeu que o Estado descumpriu com as obrigações dos arts. 1.1, 2, 4.1, 5.2, 7.1, 7.5, 7.6, 8.1 e 25.1, todos da mesma Convenção. Em relação à reparação, além da pecuniária, a Corte estipulou reparações não pecuniárias, como prestações de saúde e apoio psicológico aos familiares das vítimas, e também para construção de imóvel. Ademais, ela integra outras formas de reparação, além do dever de o Estado investigar os fatos e localizar os corpos da vítima ${ }^{325}$, colocando a questão em cenário público, na medida em que determinou a publicação da sentença da Corte no Diário Oficial peruano e em meios de comunicação, acompanhado de um pedido de perdão público aos familiares das vítimas, face aos graves danos causados por esse Estado, ratificando que esse tipo de violação não acontecerá mais no futuro. ${ }^{326}$

No caso Bámaca Velásquez vs. Guatemala ${ }^{327}$, a Corte Interamericana condenou a Guatemala em 25 de novembro de 2000, baseada na petição da Comissão que pedia investigação acerca da violação dos arts. 1, 3, 4, 5, 7, 8, 13, 25 da Convenção Americana, arts. 1, 2 e 6 da Convenção Interamericana para prevenir e sancionar a tortura. Como reparações, a Corte estabeleceu que o Estado deve localizar os restos mortais do desaparecido, exumá-los na presença de seus familiares e entregá-los a eles. Além disso, como nos casos anteriores, decidiu pela publicação da sentença no Diário Oficial e em outros meios de comunicação, determinou que houvesse adaptações legislativas e administrativas em conformidade com as

117. En razón de lo anterior, este Tribunal considera que Bolivia debe emplear todos los medios necesarios para localizar los restos mortales de la víctima y entregarlos a sus familiares. Asimismo, el Estado debe informar periódica y detalladamente las gestiones realizadas a tales efectos.

${ }^{324}$ Caso Durand e Ugarte vs. Peru, sentença de mérito, p. 17-22, para 59. Ambas as vítimas estavam presas no estabelecimento prisional San Juan Bautista, acusadas de terrorismo, quando no dia 18 de junho de 1986 iniciouse uma rebelião no sistema - mesma rebelião em que desapareceram Neira Alegría e outros. De 111 mortos, somente 7 foram identificados, contudo, os nomes de Durand e Ugarte não apareceram nas listas militares. Apesar de terem sido impetrados habeas corpus em favor das vítimas, eles não foram atendidos e, mesmo depois de ter sido ordenada a soltura dos dois, eles não apareceram.

325 Caso Durand e Ugarte vs. Peru, sentença de mérito, p. 39, para. 123. Al respecto, este Tribunal ha sostenido que, ante toda violación de derechos protegidos por la Convención, el deber de investigar debe emprenderse con seriedad y no como una simple formalidad condenada de antemano a ser infructuosa. Debe tener un sentido y ser asumida por el Estado como un deber jurídico propio y no como una simple gestión de intereses particulares, que dependa de la iniciativa procesal de la víctima o de sus familiares o de la aportación privada de elementos probatorios, sin que la autoridad pública busque efectivamente la verdad.

${ }^{326}$ Caso Durand e Ugarte vs. Peru, sentença de reparação e custas, p. 10, para. 45.

${ }^{327}$ Caso Bámaca Velásquez vs. Guatemala, sentença de mérito, p. 5, para. 18. O Sr. Bámaca Velásquez era guerrilheiro, membro da Organización Revolucionaria del Pueblo em Armas, e desapareceu no dia 12 de março de 1992, após um combate contra o exército. As forças armadas guatemaltecas negaram sua responsabilidade em relação ao caso. 
normas de Direito Internacional dos Direitos Humanos e fixou indenizações relativas aos danos materiais e morais por que passaram a família ${ }^{328}$.

A partir deste caso a Corte passou também a apreciar a dimensão social do direito à verdade, em decorrência do amicus curiae que a Comissão Internacional de Juristas apresentou em relação a esse direito, e da demanda elaborada pela Comissão de Direitos Humanos da $\mathrm{OEA}^{329}$. Nesse sentido, alegou que "a sociedade tem o direito a conhecer a verdade acerca desses crimes, com o propósito de que tenha a capacidade de preveni-los no futuro"330. Contudo, o entendimento da Corte acerca do direito à verdade é no sentido de que ele se encontra subsumido nos arts. 8 e 25 da Convenção ${ }^{331}$.

${ }^{328}$ Caso Bámaca Velásquez vs. Guatemala, sentença de reparação e custas, pp. 40-42, para. 106.

329 Caso Bámaca Velásquez vs. Guatemala, sentença de mérito, pp. 81-2, paras. 197-8: 197. En sus alegatos finales, la Comisión aseguró que, como consecuencia de la desaparición de Bámaca Velásquez, el Estado violó el derecho a la verdad de los familiares de la víctima y de la sociedad en su conjunto. Al respecto, la Comisión afirmó que el derecho a la verdad tiene un carácter colectivo, que conlleva el derecho de la sociedad a "tener acceso a información esencial para el desarrollo de los sistemas democráticos”, y un carácter particular, como derecho de los familiares de las víctimas a conocer lo sucedido con su ser querido, lo que permite una forma de reparación. La Corte Interamericana ha establecido el deber del Estado de investigar los hechos mientras se mantenga la incertidumbre sobre la suerte de la persona desaparecida, y la necesidad de brindar un recurso sencillo y rápido para el caso, com las debidas garantías. Siguiendo esta interpretación, la Comisión afirmó que este es un derecho que tiene la sociedad y que surge como principio emergente del derecho internacional bajo la interpretación dinámica de los tratados de derechos humanos y, en específico, de los artículos 1.1, 8, 25 y 13 de la Convención Americana.

198. Por su parte, el Estado limitó su defensa a afirmar que "no ha resultado posible, hasta este momento, identificar a las personas o persona responsables penalmente de los hechos antijurídicos de los que fuera objeto el señor Bámaca [Velásquez] y de ese modo esclarecer su desaparición” y, en consecuencia, no esgrimió, ni en la oportunidad procesal de contestar la demanda, ni en sus alegatos finales, defensa alguna relacionada con la supuesta violación del derecho a la verdad.

${ }^{330}$ Caso Bámaca Velásquez vs. Guatemala, sentença de mérito, p. 14, paras. 64 e 77: A partir de la Sentencia sobre reparaciones en el memorable caso Bámaca Velásquez versus Guatemala (del 22.02.2002), - célebre caso de tanta densidad cultural, - la Corte pasó a señalar también la dimensión social (a la par de la individual) del derecho a la verdad, al ponderar que "La sociedad tiene el derecho a conocer la verdad en cuanto a tales crímenes con el propósito de que tenga la capacidad de prevenirlos en el futuro".

331 Caso Bámaca Velásquez vs. Guatemala, sentença de mérito, p. 82, paras. 200-1: 200. Como ya se ha establecido en esta Sentencia en el presente caso se intentaron diferentes recursos judiciales para identificar el paradero de Bámaca Velásquez. Estos recursos no sólo no fueron efectivos, sino que se ejercieron a su respecto acciones directas de agentes del Estado de alto nivel tendientes a impedir que tuvieran resultados positivos. Estas obstrucciones fueron particularmente evidentes en lo relativo a las múltiples diligencias de exhumación que se intentaron, las que a la fecha no han permitido identificar los restos de Efraín Bámaca Velásquez. Es incuestionable que la situación reseñada impidió a Jennifer Harbury y a los familiares de la víctima conocer la verdad acerca de la suerte corrida por ésta.

201. De todos modos, en las circunstancias del presente caso, el derecho a la verdad se encuentra subsumido en el derecho de la víctima o sus familiares a obtener de los órganos competentes del Estado el esclarecimiento de los hechos violatorios y las responsabilidades correspondientes, a través de la investigación y el juzgamiento que previenen los artículos 8 y 25 de la Convención. 202. Por lo tanto, esta cuestión queda resuelta con lo establecido en el capítulo anterior, en relación con las garantías judiciales y la protección judicial. (grifos da sentença).

No mesmo sentido, na sentença de reparação e custas, p. 34, paras. 75-7: 75. Asimismo, este Tribunal estableció, en su sentencia de fondo, que por las características del caso en estudio, el derecho a la verdad se encontraba "subsumido em el derecho de la víctima o sus familiares a obtener de los órganos competentes del Estado el 
Como pela primeira vez a Corte tratou desse direito, os juízes Cançado Trindade, Salgado Pesantes e García Ramirez juntaram à sentença de mérito seus votos arrazoados. O primeiro juiz faz uma análise a partir da perspectiva dos direitos humanos da relação entre vivos e mortos, ressaltando que essa questão não foi muito tratada pelo direito, concluindo acerca da importância do direito à verdade como forma de respeito aos vivos e aos mortos. Além disso, afirma que manter os familiares sem saberem onde estão os restos de seu ente querido, bem como dos fatos que envolveram seu desaparecimento, constitui forma de tortura psicológica a todos eles ${ }^{332}$.

esclarecimiento de los hechos violatorios y las responsabilidades correspondientes, a través de la investigación y el juzgamiento que previenen los artículos 8 y 25 de la Convención”. Como lo ha señalado este Tribunal, sólo si se esclarecen todas las circunstancias de las violaciones de que se trata se podrá considerar que el Estado ha proporcionado a la víctima y a sus familiares un recurso efectivo y há cumplido con su obligación general de investigar.

76. El derecho que toda persona tiene a la verdad, ha sido desarrollado por el derecho internacional de los derechos humanos, y, como sostuvo esta Corte en anteriores oportunidades, la posibilidad de los familiares de la víctima de conocer lo sucedido a ésta, y, en su caso, dónde se encuentran sus restos, constituye un médio de reparación y, por tanto, una expectativa que el Estado debe satisfacer a los familiares de la víctima y a la sociedad como un todo.

77. Finalmente, es obligación del Estado, según el deber general establecido en El artículo 1.1 de la Convención, asegurar que estas graves violaciones no se vuelvan a repetir. En consecuencia, debe hacer todas las gestiones necesarias para lograr este fin. Las medidas preventivas y de no repetición empiezan con la revelación y reconocimiento de las atrocidades del pasado, como lo ordenara esta Corte en la sentencia de fondo. La sociedad tiene el derecho a conocer la verdad en cuanto a tales crímenes con el propósito de que tenga la capacidad de prevenirlos en el futuro.

332 Caso Bámaca Velásquez vs. Guatemala, sentença de mérito, voto arrazoado Cançado Trindade, pp. 8-11, paras. 29-40.

IV. La Prevalencia del Derecho a la Verdad, en Respeto a los Muertos y a los Vivos.

29. Varios pueblos de América Latina han, en su historia reciente, conocido y sufrido el flagelo y crueldad de la tortura, los tratos inhumanos o degradantes, las ejecuciones sumarias y arbitrarias o extra-legales, y las desapariciones forzadas de personas. La búsqueda de la verdad - como lo ilustran los casos de desaparición forzada de personas - constituye el punto de partida para la libertación así como la protección del ser humano; sin la verdad (por más insuportable que ésta venga a ser) no es posible libertarse del tormento de la incertidumbre, y tampoco es posible ejercer los derechos protegidos.

30. En efecto, la prevalencia del derecho a la verdad configúrase como uma conditio sine qua non para hacer efectivos el derecho a las garantías judiciales (artículo 8 de la Convención Americana) y el derecho a la protección judicial (artículo 25 de la Convención), reforzándose todos mutuamente, en beneficio de los familiares inmediatos de la persona desaparecida. El derecho a la verdad se reviste, así, de dimensiones tanto individual como colectiva.

31. Tiene, en mi entender, una dimensión más amplia de la que se pueda prima facie desprender del artículo 19 de la Declaración Universal de los Derechos Humanos de 1948. Más allá del enunciado en aquella disposición, que inspiró otras disposiciones congéneres de distintos tratados de derechos humanos, el derecho a la verdad, en última instancia, se impone también en señal de respeto a los muertos y a los vivos. El ocultamiento de los restos mortales de una persona desaparecida, em una flagrante falta de respeto a los mismos, amenaza romper el lazo espiritual que vincula los muertos a los vivos, y atenta contra la solidaridad que debe guiar los rumbos del género humano en su dimensión temporal.

32. En cuanto a la construcción jurisprudencial del derecho a la verdad, se puede verificar un avance entre lo señalado al respecto por la Corte en el caso Castillo Páez (Sentencia de fondo, del 03.11.1997), y lo ponderado en la presente Sentencia sobre el fondo en el caso Bámaca Velásquez (párrs. 198-199). El derecho a la verdad requiere, sí, la investigación por el Estado de los hechos lesivos, y su prevalência constituye, además, como ya observado, el presupuesto para el propio acceso efectivo a la justicia - a niveles nacional e internacional - por parte de los familiares de la persona desaparecida (las garantías y protección judiciales bajo los artículos 8 y 25 de la Convención Americana). Dado que el Estado tiene el deber de hacer cesar las violaciones de los derechos humanos, la prevalencia del derecho a la verdad es esencial para el combate a la impunidad, y se 
Para o juiz Salgado Pesantes, o direito à verdade tem natureza de direito difuso, considerando que todos têm titularidade - contudo, esse caráter não impediria que os familiares das vítimas de desaparecimento reclamassem por saber a verdade concernente ao seu caso. Desse modo, o

encuentra ineluctablemente ligada a la propia realización de la justicia, y a la garantía de no-repetición de aquellas violaciones.

33. Para la afirmación de tal derecho, en beneficio de los familiares del desaparecido, no me parece necesario acudir a la doctrina europea contemporánea - a mi modo de ver poco inspirada y aún menos inspiradora - de la así-llamada protection par ricochet. Estamos ante un legítimo ejercicio hermenéutico, en perfecta conformidad con las reglas generales de interpretación de los tratados, mediante el cual se busca asegurar el efecto propio (effet utile) de la Convención Americana sobre Derechos Humanos en el derecho interno de los Estados Partes, maximizando la salvaguardia de los derechos por ésta protegidos.

34. La propia jurisprudencia internacional en materia de derechos humanos ha dado muestras de su entendimiento de dicho ejercicio legítimo de interpretación, extendiendo la protección a situaciones nuevas a partir de los derechos preexistentes. La Corte Interamericana ha oportunamente recordado, en su importante Opinión Consultiva sobre El Derecho a la Información sobre la Asistencia Consular en el Marco de las Garantías del Debido Proceso Legal, del 01.10.1999, que "los tratados de derechos humanos son instrumentos vivos, cuya interpretación tiene que acompañar la evolución de los tiempos y las condiciones de vida actuales". 35. En la misma línea de dicha interpretación evolutiva, en su reciente Sentencia de fondo en el caso Cantoral Benavides (del 18.08.2000), la Corte Interamericana ponderó que, por ejemplo, "ciertos actos que fueron calificados en el pasado como tratos inhumanos o degradantes", pueden posteriormente, con el pasar del tiempo, venir a ser considerados "como torturas, dado que a las crecientes exigencias de protección" de los derechos humanos "debe corresponder una mayor firmeza al enfrentar las infracciones a los valores básicos de las sociedades democráticas".

36. Tanto en el caso Cantoral Benavides (párrs. 104 y 106) como en el presente caso Bámaca Velásquez (párr. 158), la Corte estableció, inter alia, la violación del artículo 5(2) de la Convención Americana, en razón de las torturas sufridas por la víctima directa (los Srs. Cantoral Benavides y Bámaca Velásquez, respectivamente). La prohibición de tratos crueles, inhumanos o degradantes, en los términos del mismo artículo 5(2) de la Convención Americana, retiene relevancia, como reconoce la Corte en la presente Sentencia, por los padecimientos sufridos por las víctimas indirectas, los familiares inmediatos del Sr. Bámaca Velásquez. La prohibición tanto de la tortura como de los tratos crueles, inhumanos o degradantes, bajo la Convención Americana y otros tratados de derechos humanos, es absoluta.

37. En efecto, el propio contenido jurídico de la prohibición absoluta de los tratos crueles, inhumanos o degradantes, en particular, ha tenido un dominio de aplicación ampliado ratione materiae, abarcando nuevas situaciones quizás no previstas al momento de su consagración en los tratados de derechos humanos. Así, la prohibición de dichos tratos ha sido invocada, bajo la Convención Europea de Derechos Humanos, en casos relativos también a la no-extradición (como el cãs célèbre Soering versus Reino Unido (1989) y a la nodeportación. Esto se há logrado mediante una interpretación evolutiva de los instrumentos internacionales de protección de los derechos del ser humano.

38. La prohibición absoluta de los tratos crueles, inhumanos o degradantes há experimentado, además, una ampliación también ratione personae, abarcando, em determinados casos (como los de desaparición forzada de persona), en cuanto a la titularidad de derechos, también los familiares de la víctima directa (en su condición de víctimas indirectas). Así, la Corte Interamericana ha establecido correctamente que, en circunstancias como las del presente caso Bámaca Velásquez, las víctimas son tanto la persona desaparecida como sus familiares inmediatos.

39. (...) Persistía, sin embargo, la necesidad de desarrollar, como he buscado hacer en este Voto Razonado, la cuestión de los vínculos y lazos de solidaridad entre los muertos y los vivos, formando la unidad del género humano, con el respeto debido a unos y a otros, para lo que se impone la prevalencia del derecho a la verdad. 40. La ampliación de la noción de víctima vuelve a ocurrir en el presente caso, em relación con los familiares inmediatos del Sr. Efraín Bámaca Velásquez. El intenso sufrimiento causado por la muerte violenta de un ser querido es aún más agravado por su desaparición forzada, y revela una de las grandes verdades de la condición humana: la de que la suerte de uno encuéntrase ineluctablemente ligada a la suerte de los demás. Uno no puede vivir en paz ante la desgracia de un ser querido. Y la paz no debería ser un privilegio de los muertos. La desaparición forzada de uma persona victimiza igualmente sus familiares inmediatos (a veces desagregando El propio núcleo familiar), tanto por el intenso sufrimiento y la desesperación causados, cuanto por sustraer a todos del manto protector del Derecho. Este entendimiento ya forma hoy, en el umbral del siglo XXI, jurisprudence constante de la Corte Interamericana de Derechos Humanos. 
direito à verdade está incluído implicitamente nos arts. 8, 11, 14 e 25 da Convenção Americana, e devem ser obedecidos alguns critérios por parte da doutrina, no sentido de elaborar sua definição para positivação de tal direito, "esta (...) prerrogativa para obter a verdade tem uma natureza essencialmente moral, a conduta oposta à verdade é a mentira, e tem um conteúdo subjetivo que é necessário delimitar, para não cair em um subjetivismo negativo; o não (...) estabelecer a verdade pode dar lugar a diferentes graus de responsabilidade"333. O juiz García Ramírez, por sua vez, vincula o saber a verdade com a possibilidade de acabar com a impunidade, que é o maior fator de continuidade de violações de direitos humanos. ${ }^{334}$

${ }^{333}$ Caso Bámaca Velásquez vs. Guatemala, sentença de mérito, voto arrazoado Salgado Pesantes: En mi criterio, la doctrina que se elabore deberá tener en cuenta cuestiones como las siguientes: - esta facultad o prerrogativa a obtener la verdad tiene una naturaleza esencialmente moral, la conducta opuesta a la verdad es la mentira, y tiene um contenido subjetivo que es necesario delimitarlo, para no caer en un subjetivismo negativo;

- el no decir, revelar o establecer la verdad puede dar lugar a diferentes grados de responsabilidad (error inintencional, premeditación, etcétera);

En todo caso, la axiología o estimativa jurídica tiene que construir una sólida doctrina que permita insertar el derecho a la verdad dentro de las normas positivas y, al mismo tiempo, determinar hasta donde debe y puede ser aplicado un derecho semejante.

${ }^{334}$ Caso Bámaca Velásquez vs. Guatemala, sentença de mérito, voto arrazoado juiz García Ramírez, pp. 4-5, paras. 17-22: 17. La Comisión Interamericana de Derechos Humanos manifestó que la desaparición forzada del señor Bámaca Velásquez acarrea una violación del derecho a la verdad, que asiste a los familiares de la víctima y a la sociedad en general. Este derecho tendría, como ha resumido la Corte, "un carácter colectivo, que conlleva el derecho de la sociedad a tener acceso a información esencial para el desarrollo de los sistemas democráticos', y un carácter particular, como derecho de los familiares de las víctimas a conocer lo sucedido con su ser querido, lo que permite una forma de reparación".

18. El derecho a la verdad se ha examinado en un doble plano, que implica uma misma --o muy semejante-consideración: saber la realidad de ciertos hechos. A partir de ese conocimiento se construirá una consecuencia jurídica, política o moral de diversa naturaleza. Por una parte, se asigna aquel derecho a la sociedad en su conjunto; por la otra, el derecho se atribuye a la víctima, directa o indirecta, de la conducta violatoria del derecho humano.

19. Bajo el primer significado, el llamado derecho a la verdad acoge una exigência legítima de la sociedad a saber lo sucedido, genérica o específicamente, en cierto período de la historia colectiva, regularmente una etapa dominada por el autoritarismo, en la que no funcionaron adecuada o suficientemente los canales de conocimiento, información y reacción característicos de la democracia. En el segundo sentido, el derecho a conocer la realidad de lo acontecido constituye un derecho humano que se proyecta inmediatamente sobre la Sentencia de fondo y las reparaciones que de aquí provienen.

20. En la resolución de la Corte a la que se asocia este voto concurrente, el Tribunal se ha ceñido a la vertiente individual del derecho a la verdad, que es el estrictamente vinculado a la Convención, a título de derecho humano. De ahí que, em la especie, ese derecho se recoja o subsuma en otro que también es materia de la Sentencia: el correspondiente a la indagación de los hechos violatorios y el enjuiciamiento de sus autores. Así, la víctima --o sus derechohabientes -- tienen el derecho a que las investigaciones realizadas o por realizar conduzcan a conocer lo que "verdaderamente" sucedió. Por ese cauce corre el derecho individual a la verdad, que halla sustento en la Convención y, a partir de ésta, en el reconocimiento que hace la Corte a través de su Sentencia.

21. Por otra parte, la satisfacción del derecho a la verdad que corresponde a las víctimas, a través de la investigación de los hechos y el enjuiciamiento de los responsables, que se difunde públicamente -- como lo ha dispuesto la Corte en los puntos resolutivos de la Sentencia -- permite atender además el requerimiento social de saber lo que ha ocurrido. Esta situación guarda parecido con la que se plantea a propósito de la eficacia que tiene, por sí misma, una sentencia declarativa de violación de derechos para reparar el agravio cometido en lo que respecta a la satisfacción moral de la víctima, tema en el que se han ocupado la jurisprudência internacional y varias resoluciones de la Corte. Esta "ha reiterado en su jurisprudencia que en relación a la 
O caso Caracazo vs. Venezuela ${ }^{335}$ foi submetido pela Comissão à Corte em 7 de junho de 1999, e, em 11 de novembro do mesmo ano, o tribunal expediu sua sentença de mérito, nos seguintes termos: violação dos arts. 1.1, 2, 4.1, 5, 7, 8.1, 25.1 e 25.2 da Convenção Americana. A Corte determinou então que o Estado deveria localizar e exumar os corpos de maneira idônea, pagar as indenizações de ordem moral e material a todas as vítimas e familiares, e os custos que tiveram as organizações não-governamentais Comité de Familiares de las Víctimas de los Sucesos de Febrero - Marzo de 1989 (COFAVIC) e Centro por la Justicia y el Derecho Internacional (CEJIL) para atuarem em prol das vítimas junto ao Sistema Interamericano de Direitos Humanos, além de tomarem todas as medidas internas para evitar que outras situações desse tipo possam ocorrer ${ }^{336}$. Dessa maneira, determina que os familiares e as vítimas sobreviventes tenham pleno acesso e capacidade para atuar nas investigações, e seus resultados devem ser plenamente divulgados, a fim de que a sociedade venezuelana conheça a verdade $\mathrm{e}^{337}$.

O caso seguinte de desaparecimento forçado de pessoas apreciado pela Corte foi o Juan Humberto Sánchez vs. Honduras ${ }^{338}$, em 7 de junho de 2003, quando condenou-se o Estado pelas violações dos arts. 4, 5, 7, 8 e 25 da Convenção. Apesar de o desaparecimento da vítima ter durado alguns dias, a Corte considerou a situação do país na época dos fatos e, somada às provas, responsabilizou Honduras por desrespeitar os direitos que compõem a prática do desaparecimento forçado. Dessa maneira, como reparação, a Corte sentenciou ao Estado hondurenho que pagasse indenizações materiais e morais, que exumasse os restos mortais da vítima e que os entregasse aos familiares, para sepultarem em um lugar onde pudessem

solicitud de que el Estado presente una disculpa pública como reparación a las violaciones cometidas, la sentencia sobre el fondo del caso constituye, en sí misma, una forma de reparación y satisfacción moral de significación e importancia para la víctima y sus familiares...".

22. Esta es la primera vez que la Corte se refiere explícitamente al derecho a la verdad, aducido en la demanda de la Comisión. La novedad que la Sentencia aporta en este punto pudiera conducir a mayor exploración en el porvenir, que contribuya a fortalecer el papel de la jurisprudencia interamericana sobre derechos humanos como factor de lucha contra la impunidad. La demanda social de conocimiento de los hechos violatorios y el derecho individual al conocimiento de la verdad se dirigen claramente al destierro de la impunidad, que propicia la violación de los derechos humanos.

335 Em fevereiro de 1989, em razão de certas mudanças de ordem econômica determinadas pelo presidente da República, houve diversas manifestações da população, seguida da tomada do poder pelas forças armadas por 23 dias, enquanto as liberdades constitucionais foram suprimidas. Muitas pessoas foram mortas, e 4 despareceram nesse momento de exceção. Caso Caracazo vs. Venezuela, sentença de mérito, pp. 3-6, para. 2.

${ }^{336}$ Caso Caracazo vs. Venezuela, sentença de reparação e custas, pp. 112-16, para. 143.

${ }^{337}$ Caso Caracazo vs. Venezuela, sentença de reparação e custas, pp. 106-7, para. 118.

338 A vítima trabalhava na rádio Venceremos del Frente para la Liberación Farabundo Martí em El Salvador. Na noite de 11 de julho de 1992 um grupo de militares armados entrou na casa dos pais da vítima e levaram-no amarrado, sem dar explicações. O corpo da vítima foi encontrado no dia 21 de julho do mesmo ano em um poço. Caso Juan Humberto Sánchez vs. Honduras, sentença de mérito, reparação e custas, pp 30-38, para. 70, b. 
guardar sua memória $^{339}$, e que estabelecesse todos os esforços internos para não acontecerem mais essas graves violações de direitos ${ }^{340}$.

O primeiro caso de desaparecimento forçado levado à Corte pela Comissão, em 4 de julho de 2003, com base também na Convenção Interamericana sobre Desaparecimento Forçado de Pessoas foi Molina Theissen vs. Guatemala ${ }^{341}$, alegando violação aos arts. 4, 5, 7, 8, 19 e 25 da Convenção Americana, e arts. 1 e 2 da Convenção Interamericana sobre Desparecimento Forçado. O presidente da Guatemala reconheceu em 2000 a responsabilidade internacional do Estado frente ao caso em tela. A Corte, em sua decisão proferida em 4 de maio de 2004, determinou a violação dos artigos acima elencados em prejuízo da vítima. Também declarou a violação aos direitos dos familiares, arts. 1.1, 2, 5.1, 5.2, 8, 17, $25^{342}$.

Em 5 de julho de 2004 a Corte julgou o caso 19 Comerciantes vs. Colômbia ${ }^{343}$, a partir de encaminhamento feito pela Comissão na data 24 de janeiro de 2001, condenando a Colômbia por violação aos arts. 4, 5 e 7 da Convenção Americana em relação aos desaparecidos, e 8.1 e 25 aos desaparecidos e seus familiares. Estabelece, a título de reparações, que o Estado colombiano deveria investigar e punir os responsáveis por tais violações, além de realizar uma busca séria no sentido de localizar os restos mortais dos 19 desaparecidos, erigir um

\footnotetext{
${ }^{339}$ Em razão do grau de decomposição do corpo quando encontrado, ele foi imediatamente sepultado, sem que a família pudesse escolher o local de enterro. Caso Juan Humberto Sánchez vs. Honduras, sentença de mérito, reparação e custas, p. 101, para. 187: Relacionado con lo anterior, esta Corte ha señalado en reiteradas ocasiones que asiste a los familiares el derecho a conocer dónde se encuentran los restos de su ser querido, y ha establecido que ello "representa una justa expectativa que el Estado debe satisfacer con los medios a su alcance". A su vez el Tribunal há considerado recientemente que "la entrega de los restos mortales constituye um acto de reparación en sí mismo porque conduce a dignificar a las víctimas, al hacerle honor al valor que su memoria tiene para los que fueron sus seres queridos y permitirle a éstos darles una adecuada sepultura". En razón de lo anterior, este Tribunal considera que el Estado debe brindar las condiciones necesarias para trasladar los restos mortales de la víctima al lugar de elección de sus familiares, sin costo alguno para ellos.

${ }^{340}$ Caso Juan Humberto Sánchez vs. Honduras, sentença de mérito, reparação e custas, pp. 100-02, paras. 18489 .

${ }^{341}$ Este caso refere-se ao desaparecimento forçado de uma criança de 14 anos, que foi seqüestrado na casa de seus pais por membros do exército guatemalteco em 6 de outubro de 1981. Caso Molina Theissen vs. Guatemala, sentença de mérito, p. 12, para. 40.12: la detención y posterior desaparición forzada de Marco Antonio Molina Theissen fue ejecutada por efectivos del ejército guatemalteco, presuntamente como represalia por la fuga de su hermana Emma Guadalupe Molina Theissen del Cuartel Militar "Manuel Lisandro Barillas", y como castigopara una familia considerada por ellos como "enemiga".

${ }^{342}$ Caso Molina Theissen vs. Guatemala, sentença de mérito, p. 15-6, para. 43 e 47.

${ }^{343}$ Alguns comerciantes da região de Puerto Boyacá costumavam fazer compras fora deste município, e voltavam para revender. Esse município, contudo, estava sob controle de um grupo paramilitar, que cobravam uma espécie de "pedágio", para que todos pudessem exercer suas atividades. Contudo, esse grupo composto por 17 comerciantes se recusava a pagar tal propina, de modo que foram assassinados no dia 6 ou 7 de outubro de 1987, quando saíram para fazer compras, e seus corpos foram esquartejados e jogados no rio El Ermitaño. Cerca de quinze dias depois, duas pessoas próximas às vítimas, em buscas na região onde o grupo paramilitar operava, tiveram a mesma sorte dos desaparecidos. O grupo paramilitar era sabidamente composto por membros das forças armadas. Caso 19 Comerciantes vs. Colômbia, sentença de mérito, reparações e custas, p. 42, paras. 85-6.
} 
monumento em memória aos desaparecidos e inaugurá-lo em cerimônia pública com a presença dos familiares, oferecer tratamento de saúde e psicológico aos familiares das vítimas que assim queiram, e declarar em ato público sua responsabilidade internacional pelo caso. Ademais, foram estipuladas as indenizações de dano material e moral em favor das vítimas, além de estabelecido o ressarcimento às organizações não-governamentair CEJIL e Comisión Colombiana de Juristas, face aos seus gastos com os trâmites junto ao Sistema Interamericano de Direitos Humanos.

Neste caso a Corte manifesta a importância do direito que as vítimas têm de saberem o que aconteceu com seus familiares desaparecidos, atrelando a conhecerem quem foram os responsáveis pelas violações. Aponta a importância do exercício do direito à verdade em caso concreto como meio de satisfazer e reparar as vítimas. Dessa maneira, relaciona saber a verdade por meio da investigação e responsabilização dos perpetradores dos desaparecimentos. $^{344}$

O caso Irmãs Serrano Cruz vs. El Salvador ${ }^{345}$, julgado em 1 de março de 2005 pela Corte, a partir de submissão pela Comissão datada de 14 de junho de 2003, condenado esse país nos arts. 5, 8.1, 17, 18 e 19, em relação às crianças e aos familiares. Quanto às medidas reparatórias, determinou que o Estado deveria adotar diversas medidas para localizar o paradeiro das vítimas, como uma comissão de busca de jovens que desapareceram na época dos conflitos, a criação de uma página na internet para a busca e de um sistema de informação genética, e, finalmente, a criação de uma poupança em benefício das crianças por dez anos, ou até que apareçam. Fixou também indenizações materiais e morais aos familiares e obrigou o

\footnotetext{
344 Caso 19 Comerciantes vs. Colômbia, sentença de mérito, reparações e custas, p. 42, paras. 85-6, sentença de mérito, reparação e custas, p. 121, paras. 260-1: 260. El Estado tiene el deber de evitar y combatir la impunidad, que la Corte ha definido como "la falta en su conjunto de investigación, persecución, captura, enjuiciamiento y condena de los responsables de las violaciones de los derechos protegidos por la Convención Americana”. Al respecto, la Corte ha advertido que [...] el Estado tiene la obligación de combatir tal situación por todos los medios legales disponibles ya que la impunidad propicia la repetición crónica de las violaciones de derechos humanos y la total indefensión de las víctimas y de sus familiares.

261. La Corte considera que las víctimas de graves violaciones de derechos humanos y sus familiares, en su caso, tienen el derecho a conocer la verdad. En consecuencia, los familiares de las víctimas deben ser informados de todo lo sucedido en relación con dichas violaciones. Este derecho a la verdad ha venido siendo desarrollado por el Derecho Internacional de los Derechos Humanos; al ser reconocido y ejercido en una situación concreta, ello constituye un medio importante de reparación. Por lo tanto, en este caso da lugar a una expectativa que el Estado debe satisfacer a los familiares de las víctimas.

${ }^{345}$ No dia 2 de junho de 1982, durante a chamada Operação Limpeza, realizada pelo batalhão Atlacatl, do exército elsalvadorenho, ocorreu a captura, seqüestro e desaparecimento forçado de duas crianças, as irmãs Serrano Cruz, de 7 e 3 anos. A família inteira fugiu, tentando salvar suas vidas, mas as crianças foram encontradas pelo batalhão, enquanto se escondiam e, desde então, desapareceram. Cerca de 145 crianças desapareceram nessa época de conflito interno no país, que aconteceu de 1980 a 1991. Caso caso Irmãs Serrano Cruz vs. El Salvador, sentença de mérito, reparação e custas, p. 2-3 para. 2
} 
Estado a oferecer-lhes gratuitamente tratamentos de saúde. Além disso, o Estado deveria designar um dia dedicado à memória dessas crianças que desapareceram na época dos conflitos $^{346}$.

O juiz Ventura Robles, em seu voto discidente, aponta importante questão relativa à formação da identidade pessoal das crianças em questão. Ele imputa a responsabilidade do Estado de buscar essas crianças e adotar todas as medidas necessárias para que elas saibam de sua história familiar, da procura de toda a vida de sua mãe e de seus irmãos. Seria forma então de a família reconstituir seus laços, de as crianças terem o nome de seus pais, repercutindo-se em benefício para toda a sociedade hondurenha. Ademais, o empenho do Estado em localizar as crianças desaparecidas no marco do conflito interno, seria a maneira de conhecer a verdade que se sucedeu à época dos fatos. ${ }^{347}$

Em 15 de setembro de 2005, a Corte Interamericana julgou mais um caso de desaparecimento, chamado "Masacre de Mapiripán" vs. Colômbia ${ }^{348}$, encaminhado pela Comissão em 5 de setembro de 2003, condenando o país em violação aos arts. 1.1, 4.1, 5.1, 5.2, 7.1 e 7.2 das vítimas, além de direitos das crianças e direitos de residência e livre circulação - em decorrência dos deslocamentos internos. A Corte estabeleceu que a Colômbia deveria identificar todas as vítimas do massacre, apurar as responsabilidades, construir um monumento digno para lembrar dessas vítimas em Mapiripán, inserir na formação dos agentes das forças armadas as matérias de direito internacional humanitário e direitos humanos, além de fixar as indenizações materiais e imateriais aos familiares das vítimas ${ }^{349}$.

Dada a natureza deste caso, a Corte acredita que editar uma sentença em que se determinem a verdade dos fatos e todos os elementos que envolveram o massacre, assim como suas conseqüências, constitui forma de reparação para os familiares das vítimas. Assim, a Corte segue entendendo que a verdade estabelece um elemento de reparação a que as vítimas têm

\footnotetext{
${ }^{346}$ Caso Irmãs Serrano Cruz vs. El Salvador, sentença de mérito, reparação e custas, pp. 106-9, para. 218.

${ }^{347}$ Caso caso Irmãs Serrano Cruz vs. El Salvador, sentença de mérito, reparação e custas, p. 16-7, paras. 7-8.

348 Entre 15 de 20 de julho de 1997, cerca de cem membros das Autodefesas Unidas da Colômbia, com colaboração e aquiescência dos agentes do Estado, privara de liberdade, torturaram e assassinaram ao menos 49 civis, destruíram seus corpos e jogaram os restos no rio Guaviare, município de Mapiripán. Foram identificadas dentre essas vítimas 20 pessoas e alguns de seus familiares. Esses grupos de autodefesa, formado por civis que não estavam em serviço militar, tinham todo o apoio do governo que os instituiu na década de 1960, em razão do combate às guerrilhas - FARC. Na década de 1980 muitos desses grupos transformaram-se em grupos paramilitares, esquadrões da morte, desvirtuados dos objetivos de sua criação. Caso "Masacre de Mapiripán" vs. Colômbia, sentença de mérito, reparação e custas, p. 2, para. 2.

${ }^{349}$ Caso "Masacre de Mapiripán” vs. Colômbia, sentença de mérito, reparação e custas, pp. 179-182, para. 335.
} 
direito, e que ela está implícita no dever de investigar dentro de um processo penal, assegurando a devida apuração dos fatos e a responsabilidade dos agentes violadores. ${ }^{350}$

Em seguida, a Corte julgou o caso Gómez Palomino vs. Peru ${ }^{351}$, na data 22 de novembro de 2005, encaminhado pela Comissão em 13 de setembro de 2004, com base na violação dos arts. 1.1, 4, 5 e 7 da Convenção Americana em relação ao desaparecido e 8.1 e 25 de seus familiares; além do art. I (b) da Convenção Interamericana sobre Desaparecimento Forçado de Pessoas. As medidas de reparação adotadas neste caso foram a restituição dos restos mortais para que a família pudesse fazer seu devido sepultamento, e conceder tratamento de saúde aos familiares, além de indenizações morais e materiais ${ }^{352}$. Neste caso, a Corte deu continuidade a seu entendimento de que o exercício do direito à verdade pelas vítimas em situação concreta é um meio importante de reparação ${ }^{353}$.

Em sua sentença de 28 de novembro de 2005, no caso Blanco Romero e outros vs. Venezuela $^{354}$, encaminhado à Corte em 9 de julho de 2004, foi decidido que houve violação aos arts. 1.1, 2, 4.1, 5.1, 5.2, 7.1, 7, 8.1, 25 da Convenção Americana, arts. 1, 5, 6, 7 e 8 da Convenção Interamericana para Prevenir e Sancionar a Tortura e arts. I.a e I.b, X e XI da Convenção Interamericana sobre Desaparecimento Forçado de Pessoas. Dispôs que o Estado venezuelano deveria localizar essas pessoas e, caso estivessem mortas, deveria encontrar os restos mortais e entregá-los às famílias. Ademais, condenou o Estado a indenizar os familiares material e moralmente, além de arcar com as custas de procedimentos com as buscas.

\footnotetext{
${ }^{350}$ Caso "Masacre de Mapiripán” vs. Colômbia, sentença de mérito, reparação e custas, p. 17, para. 69, p. 134, para. 216, p. 170, para. 297.

${ }^{351}$ A vítima em questão foi ilegalmente presa, e desapareceu; em 9 de julho de 1992 entraram em sua casa e o detiveram, sem justificar a prisão. Seus familiares nunca mais o encontraram, e o nome da vítima foi inclusa na Comissão de Verdade e Reconciliação. A responsabilidade por este desaparecimento foi atribuída ao Grupo Colina, um dos principais grupos de extermínio e desaparecimentos do Peru. Caso Gómez Palomino vs. Peru, sentença de mérito, reparação e custas, pp. 1-2, para. 1.

${ }^{352}$ Caso Gómez Palomino vs. Peru, sentença de mérito, reparação e custas, pp. 54-6, para. 162.

${ }^{353}$ Caso Gómez Palomino vs. Peru, sentença de mérito, reparação e custas, p. 32, paras. 78-9.

${ }^{354}$ Em dezembro de 1999 foi decretado estado de alerta em diversos estados da Venezuela que, devido a desastres naturais, o Executivo decidiu tomar medidas para evitar danos maiores. Nesse contexto, a guarda nacional e as forças armadas foram chamadas para restabelecer a ordem pública, devido à situação de insegurança por que sofria a população. No dia 21 desse mês um destacamento do exército (Batallón de Infantería 'Coronel Antonio Nicolás Briceño') entrou na casa de Blanco Romero, agredindo-o, e levando-o preso, de modo que seus familiares nunca mais a encontraram. $\mathrm{O}$ mesmo aconteceu às duas outras vítimas, Srs. Hernández Paz e Rivas Fernández, que, diante das mesmas circunstâncias, foram levados por esse batalhão do exérctio e não apareceram mais. Caso Blanco Romero e outros vs. Venezuela, sentença de mérito, reparação e custas, pp. 21-8, para. 51
} 
Também determinou que deve incluir em sua legislação a tipificação do desaparecimento, com vistas a criar medidas de prevenção e punição a este ato internamente ${ }^{355}$.

Neste caso, os representantes da vítima alegaram ter havido violação ao direito à verdade, consagrado nos arts. 8, 13, 25 da Convenção Americana, por parte do Estado da Venezuela, contudo, a Corte manifestou seu entendimento de que o direito à verdade não é um direito autônomo, reafirmando seu posicionamento de que se encontra subsumido no direito de a vítima e de seus familiares obterem não só as informações das autoridades competentes acerca das violações mas também as responsabilidades correspondentes, por meio de investigação e punição ${ }^{356}$. No voto arrazoado do juiz Cançado Trindade a este caso, é feita uma análise acerca da relação do direito à verdade com as formas de reparação. Ele aponta a relevância da iniciativa da Corte em considerar as medidas de reparação que compreendem o sofrimento das vítimas, e a preservação de sua memória coletiva. ${ }^{357}$

${ }^{355}$ Caso Blanco Romero e outros vs. Venezuela, sentença de mérito, reparação e custas, pp. 48-52, para. 125.

${ }^{356}$ Caso Blanco Romero e outros vs. Venezuela, sentença de mérito, reparação e custas, p. 32, para. 62. La Corte no estima que el derecho a la verdad sea un derecho autônomo consagrado en los artículos 8, 13, 25 y 1.1 de la Convención, como fuera alegado por los representantes, y por lo tanto no homologa el reconocimiento de responsabilidad del Estado en este punto. El derecho a la verdad se encuentra subsumido en El derecho de la víctima o sus familiares a obtener de los órganos competentes del Estado el esclarecimiento de los hechos violatorios y las responsabilidades correspondientes, a través de la investigación y el juzgamiento.

94. El Tribunal ha establecido que prevalece, después de seis años, la impunidad respecto de los hechos del presente caso. La Corte ha definido la impunidad como la falta en su conjunto de investigación, persecución, captura, enjuiciamiento y condena de los responsables de las violaciones de los derechos protegidos por la Convención Americana. El Estado está obligado a combatir esta situación por todos los medios disponibles, ya que ésta propicia la repetición crónica de las violaciones de derechos humanos y la total indefensión de las víctimas y de sus familiares.

95. Asimismo, los familiares de víctimas de graves violaciones de derechos humanos tienen el derecho de conocer la verdad. Este derecho a la verdad, al ser reconocido y ejercido en una situación concreta, constituye un medio importante de reparación para la víctima y sus familiares y da lugar a una expectativa que el estado debe satisfacer. Por otra parte el conocer la verdad facilita a la sociedad venezolana la búsqueda de formas de prevenir este tipo de violaciones en el futuro.

96. En consecuencia, los familiares de las víctimas tienen el derecho, y los Estados la obligación, a que lo sucedido a aquellas sea efectivamente investigado por las autoridades del Estado, se siga un proceso contra los presuntos responsables de estos ilícitos y, en su caso, se les impongan las sanciones pertinentes.

357 Caso Blanco Romero e outros vs. Venezuela, sentença de mérito, reparação e custas, voto arrazoado juis Cançado Trindade, pp. 1-5, paras. 1, 2, 10, 11. 1. He concurrido con mi voto para la adopción de la presente Sentencia de la Corte Interamericana de Derechos Humanos en el caso Blanco Romero y Otros versus Venezuela. Me veo, además, en la obligación de dejar constancia, en este Voto Razonado, de las reflexiones personales que me ha suscitado la presente Sentencia de la Corte, en particular en relación con el derecho a la verdad y con las formas de reparación, tal como lo he hecho, en cuanto a este segundo punto, en mis anteriores Votos Razonados en el caso de Myrna Mack Chang versus Guatemala (Sentencia del 25.11.2003), y en el caso de la Masacre de Plan de Sánchez (Sentencia de reparaciones del 19.11.2004).

2. En la presente Sentencia, la Corte ha valorado positivamente el reconocimiento de responsabilidad internacional efectuado por el Estado (párr. 63), al mismo tiempo en que también ha advertido para la importancia del derecho a la verdad, en sus dimensiones tanto individual (como medio de reparación para la víctima y sus familiares) como social (que atañe a todo el tejido social).

10. En efecto, las reparaciones de carácter ejemplarizante o disuasivo ya marcan presencia en la jurisprudencia de esta Corte. Así, por ejemplo, en el caso Aloeboetoe versus Suriname (Sentencia del 10.09.1993), la Corte 
Em 31 de janeiro de 2006, a Corte julgou o caso Massacre de Pueblo Bello vs. Colômbia ${ }^{358}$, e condenou o Estado em violação aos arts. 1.1, 4.1, 5.1, 5.2, 7.1, 7.2, 8.1, 13 e 25, em relação às vítimas e seus familiares. Determinou que a Colômbia deveria apurar a responsabilidade de todos os participantes do massacre com premência, localizar os restos mortais das vítimas e entregá-los às famílias. Ordenou que consistem reparações a organização de um ato de pedido público de desculpas pelo massacre e a construção de um monumento para lembrar do massacre. Para os familiares, determinou que fosse oferecido tratamento gratuito de saúde e fixou indenizações morais e materiais ${ }^{359}$. Quanto ao direito à verdade, a Corte manteve sua compreensão como no caso anterior ${ }^{360}$.

No caso Goiburú e outros vs. Paraguai ${ }^{361}$, julgado pela Corte em 22 de setembro de 2006, submetido pela Comissão em 8 de junho de 2005, foi considerado que o Estado paraguaio

ordenó la reapertura de una escuela y la creación de uma fundación para asistir a los beneficiarios. En el caso Villagrán Morales y Otros versus Guatemala (caso de los "Niños de la Calle", Sentencia del 26.05.2001), la Corte ordenó uma vez más la designación de un centro educativo con nombre alusivo a las víctimas del caso; de modo similar, en el caso Trujillo Oroza versus Bolivia (Sentencia del 27.02.2002), la Corte volvió a ordenar la designación de un centro educativo con el nombre de la víctima.

11. Me parecen particularmente significativas, y ejemplarizantes, las medidas de reparación tendientes al reconocimiento del sufrimiento de los victimados y a la preservación de su memoria colectiva. Otros ejemplos pertinentes de la jurisprudencia de la Corte pueden ser aqui recordados. En el caso Cantoral Benavides versus Perú (Sentencia del 03.12.2001), v.g., la Corte ordenó al Estado proporcionar una beca de estudios universitarios a la víctima. En El caso Barrios Altos relativo al Perú (Sentencia del 30.11.2001), la Corte dispuso sobre reparaciones en prestaciones educativas y el pago de gastos de servicios de salud.

${ }^{358}$ Este caso consiste no desaparecimento forçado de 37 pessoas, assim como a execução extrajudicial de 6 camponeses da população de Pueblo Bello, em janeiro de 1990. Esses atos foram cometidos por grupos paramilitares, com a aquiescência de agentes do Estado. Após 15 anos do desaparecimento dessas vítimas, somente 6 casos haviam sido aclarados pelos tribunais internos. Caso Massacre de Pueblo Bello vs. Colômbia, sentença de mérito, reparação e custas, p. 2, para. 2.

${ }^{359}$ Caso Massacre de Pueblo Bello vs. Colômbia, sentença de mérito, reparação e custas, pp. 150-3, para. 296.

${ }^{360}$ Caso Massacre de Pueblo Bello vs. Colômbia, sentença de mérito, reparação e custas, p.130 219. En cuanto al llamado derecho a la verdad, este Tribunal lo ha entendido como parte del derecho de acceso a la justicia, como una justa expectativa que el Estado debe satisfacer a las víctimas de violaciones de derechos humanos y a sus familiares y como una forma de reparación. Por ende, en su jurisprudencia la Corte há analizado el derecho a la verdad dentro de los artículos 8 y 25 de la Convención, así como en el capítulo relativo a otras formas de reparación245. Según fue recientemente señalado en el caso Blanco Romero vs. Venezuela, la Corte no estima que el derecho a la verdad sea un derecho autónomo consagrado en los artículos 8, 13, 25 y 1.1 de la Convención, como fuera alegado por los representantes. El derecho a la verdad se encuentra subsumido en el derecho de la víctima o sus familiares a obtener de los órganos competentes del Estado el esclarecimiento de los hechos violatorios y las responsabilidades correspondientes, a través de la investigación y el juzgamiento.

${ }^{361}$ Este caso refere-se ao desaparecimento forçado de 4 pessoas, Goiburú Goménez, Mancuello Bareiro, e os irmãos Ramirez Villalba, cujas posições políticas eram diversas de Stroessner Matiauda. Eles foram acusados de terrorismo e de organizarem atos contra o governo paraguaio. Goiburú foi preso, torturado e desapareceu em 1977, as outras 3 vítimas foram detidas em 1974, na fronteira de Argentina e Paraguai, todos por agentes do Estado. Esse caso diz trata da ação coordenada entre as forças de segurança dos países, na Operação Condor. Caso Goiburú e outros vs. Paraguai, sentença de mérito, reparação e custas, p. 2, § 2-3. Voto arrazoado Cançado Trindade, p. 3, para. 9. A pesar de la gravedad de los hechos del presente caso, ni todo ha sido suficientemente aclarado hasta la fecha sobre los detalles de la Operación Cóndor (en el marco de la cual se sitúa el caso Goiburú y Otros). Mediante dicha Operación las fuerzas de seguridad de los Estados del Cono Sur se 
violou os arts. 1.1, 4.1, 5.1, 5.2, 7, 8.1 e 25 da Convenção, de modo que o próprio Estado assumiu sua responsabilidade diante das violações. Decidiu a Corte que o Estado deveria finalizar as investigações e identificar os responsáveis por tais violações, localizar os restos mortais das vítimas e arcar com os custos do enterro, além de realizar um ato público para assumir sua responsabilidade ante o caso, construir um monumento em homenagem às quatro vítimas, e conceder indenizações morais e materiais aos familiares ${ }^{362}$. Apontou também que uma sentença determinando a verdade dos fatos contribui para a preservação da memória histórica do país. Ademais, destacou que o fato de a família não poder honrar apropriadamente seus entes queridos, mediante um enterro digno, constitui trato cruel e degradante para os familiares ${ }^{363}$.

No caso La Cantuta vs. Peru ${ }^{364}$, julgado pela Corte em 29 de novembro de 2006, a partir da submissão da Comissão em 14 de fevereiro do mesmo ano, o Estado peruano foi declarado responsável por violar os arts. 4.1, 5.1, 5.2 e 7 de todos os estudantes e professor, além dos arts. 8.1 e 25 de seus familiares, todos em conjunto com o art. 1.1 da mesma Convenção Americana. Como os corpos de oito das dez vítimas não haviam sido localizados, a Corte

coordinaron, al más alto nivel de comando, para detener ilegal o arbitrariamente, secuestrar, torturar, asesinar o desaparecer miles de personas.

${ }^{362}$ Caso Goiburú e outros vs. Paraguai, sentença de mérito, reparação e custas, p. 96, § 192.

363 Caso Goiburú e outros vs. Paraguai, sentença de mérito, reparação e custas, p. 15, para. 53. Teniendo en cuenta las atribuciones que le incumben de velar por la mejor protección de los derechos humanos y dada la naturaleza del presente caso, el Tribunal estima que dictar una sentencia en la cual se determine la verdad de los hechos y todos los elementos del fondo del asunto, así como las correspondientes consecuencias, constituye una forma de contribuir a la preservación de la memoria histórica, de reparación para los familiares de las víctimas y, a la vez, de contribuir a evitar que se repitan hechos similares.

Sentença de mérito, reparação e custas, pp. 66-7, para 101. A su vez, la Corte ha constatado las situaciones vividas por los familiares com posterioridad a la detención y desaparición de las víctimas:

e) por otro lado, puesto que las cuatro víctimas mencionadas aún se encuentran desaparecidas, los familiares no han contado con la posibilidad de honrar apropiadamente a sus seres queridos. Al respecto, la Corte recuerda que la privación continua de la verdad acerca del destino de un desaparecido constituye una forma de trato cruel, inhumano y degradante para los familiares cercanos.

Sentença de mérito, reparação e custas, pp. 72-4, 116, Efectividad de los recursos para la conducción de las acciones oficiales de investigación y para asegurar, en un plazo razonable, los derechos de acceso a la justicia, a la verdad de los hechos y a la reparación de los familiares. Para. 116. Corresponde entonces analizar y precisar si estos procesos penales han constituido um recurso efectivo para asegurar los derechos de acceso a la justicia, la verdad de los hechos y la reparación de los familiares, o si han existido otro tipo de recursos para estos efectos.

Caso Sentença de mérito, reparação e custas, p. 90, a) Obligación de investigar los hechos que generaron las violaciones del presente caso, e identificar, juzgar y sancionar a los responsables. Para. 164. El Estado está obligado a combatir la situación de impunidad que impera en el presente caso por todos los medios disponibles, ya que ésta propicia la repetición crónica de las violaciones de derechos humanos y la total indefensión de las víctimas y de sus familiares, quienes tienen derecho a conocer la verdad de los hechos. Este derecho a la verdad, al ser reconocido y ejercido en una situación concreta, constituye un médio importante de reparación y da lugar a una justa expectativa de las víctimas, que el Estado debe satisfacer.

$364 \mathrm{O}$ presente caso diz respeito à violação de direitos humanos de 1 professor e 9 alunos na Universidad Nacional de Educación Enrique Guzmán y Valle - La Cantuta, cometida por agentes do exército peruano, no dia 18 de julho de 1992. La Cantuta vs. Peru, sentença de mérito, reparação e custas, p. 2, para. 2. 
determinou que fossem encontrados e devolvidos às famílias. Nao obstante, decidiu pela perseguição e punição dos responsáveis pelos atos, emitindo um ato público de reconhecimento. Finalmente, a Corte determinou a construção de um monumento à memória das vítimas chamado "El Ojo que Llora", o pagamento de indenizações aos familiares por danos materiais e imateriais, além de tratamentos de saúde às famílias ${ }^{365}$.

O caso Heliodoro Portugal vs. Panamá ${ }^{366}$, julgado em 12 de agosto de 2008 pela Corte após encaminhamento da Comissão em 23 de janeiro de 2007, teve como resultado a condenação do Estado por violação aos arts. 1.1, 5.1, 7, 8.1 e 25.1 da Convenção Americana, além dos arts. I, II e III da Convenção Interamericana sobre Desaparecimento Forçado de Pessoas, e arts. 1, 6 e 8 da Convenção Interamericana para Prevenir e Punir a Tortura. Esse tribunal estipulou como medidas reparatórias a indenização moral e material aos familiares da vítima, tratamentos de saúde aos familiares, reconhecimento público internacional das violações, circulação da sentença em Diário Oficial e em meio de comunicação de grande circulação, e investigação e punição dos responsáveis ${ }^{367}$. Importante assinalar que a Comissão de Verdade do Panamá tratou do caso em tela.

O caso seguinte julgado pela Corte em 26 de novembro de 2008, a partir de demanda da Comissão de 28 de julho de 2007, refere-se ao caso Tiu Tojín vs. Guatemala ${ }^{368}$, em que se considerou terem sido violados os arts. 4.1, 5.1, 5.2, 7.1, 7.2, 7.4, 7.5, 7.6, 8.1, 19 e 25.1 da Convenção Americana e art. I da Convenção Interamericana sobre Desaparecimento Forçado de Pessoas, em prejuízo das vítimas e seus familiares. O fato de o Estado ter assumido sua

\footnotetext{
${ }^{365}$ La Cantuta vs. Peru, sentença de mérito, reparação e custas, pp. 114-8, para. 254. No mesmo sentido, a Corte determinou que os restos mortais dos desaparecidos deveriam ser tratados dignamente.

Sentença de mérito, reparação e custas, p. 110, para. 231. El derecho de los familiares de conocer dónde se encuentran los restos mortales de éstas 183 constituye una medida de reparación y por tanto una expectativa que el Estado debe satisfacer a los familiares de las víctimas184. Asimismo, el Tribunal ha señalado que los restos mortales de una persona merecen ser tratados con respeto ante sus deudos, por la significación que tienen para éstos.

${ }^{366}$ No dia 14 de maio de 1970 o Sr. Heliodoro Portugal foi detido e levado por agentes vestidos de civis. Sua filha só denunciou seu desaparecimento em maio de 1990, quando o país voltou à democracia - sua justificativa pela espera de 20 anos para a denúncia reside no fato de que durante a ditadura não era possível fazer esse tipo de investigação, acerca do paradeiro de uma pessoa. Em 1999, em um quartel chamado "Los Plumas", o Ministério Público localizou os restos da vítima em tela. Caso Heliodoro Portugal vs. Panamá, sentença de mérito, reparação e custas, p. 2, para. 2.

${ }^{367}$ Caso Heliodoro Portugal vs. Panamá, sentença de mérito, reparação e custas, pp. 114-8, para. 275.

368 María Tiu Tojín e sua filha desapareceram em 29 de agosto de 1990, por atos de agentes do exército guatemalteco e membros das patrulhas de autodefesa civil; a vítima em questão era parte de movimentos de resistência. A Guatemala, durante 1962 a 1996 viveu um período de conflito armado interno, em que se estima terem sido arbitrariamente executadas e desaparecidas mais de duzentas mil pessoas, sendo que a maioria das vítimas de violências - 83\% - eram de alguma etnia maia. Caso Tiu Tojín vs. Guatemala, sentença de mérito, reparação e custas, pp. 2, 19, paras. 2, 48.
} 
responsabilidade diante das violações tem efeito importante no cumprimento das reparações estabelecidas pela Corte, que se basearam no pagamento integral das custas e gastos com o caso, na publicação de trechos da sentença em diário oficial e mídia de grande circulação, na leitura desses mesmos trechos em rádio, no idioma $K^{\prime} i c h e^{\prime} e$ em espanhol, além do início às buscas pelos restos mortais das vítimas e julgamento e punição dos responsáveis ${ }^{369}$. Nesse sentido:

Desde sua primeira sentença no caso Velasquez Rodriguez, a Corte tem reiterado que o desaparecimento forçado de pessoas constitui um ato ilícito de natureza contínua ou permanente e de caráter pluriofensivo, pois não só se produz uma privação arbitrária da liberdade, mas também põe em perigo a integridade pessoal, a segurança e a própria vida da pessoa detida. O caráter permanente e pluriofensivo do desaparecimento forçado de pessoas é tratado nos artigos II e III da Convenção Interamericana sobre Desaparecimento Forçado de Pessoas. No caso sub judice, a Comissão solicitou ao tribunal que dê uma sentença de mérito dando por estabelecidos os fatos "em razão da importância que o estabelecimento de uma verdade oficial do acontecido tem para as vítimas de violações aos direitos humanos e em este caso para a sociedade guatemalteca como um todo". Os representantes reiteraram esta solicitação e indicaram que as sentenças desse tribunal são per se uma forma de reparação e dão grandes aportes nos processos de verdade e justiça. ${ }^{370}$

O caso Ticona Estrada e outros vs. Bolívia ${ }^{371}$, julgado em 27 de novembro de 2008, foi encaminhado pela Comissão em 8 de agosto de 2007, e o tribunal decidiu que houve violação aos arts. 1.1, 4.1, 5.1, 5.2, 8.1 da Convenção Americana e arts. I (a, b, d) e III da Convenção Interamericana sobre Desaparecimento Forçado, em prejuízo da vítima e de seus familiares, e aceitou o reconhecimento parcial do Estado boliviano pelas violações. Condenou a Bolívia a

\footnotetext{
${ }^{369}$ Caso Tiu Tojín vs. Guatemala, sentença de mérito, reparação e custas, pp. 43-3, para. 135.

${ }^{370}$ Caso Tiu Tojín vs. Guatemala, sentença de mérito, reparação e custas, p. 20, para. 52. Desde su primera sentencia en el caso Velásquez. Rodríguez67, la Corte há reiterado que la desaparición forzada de personas constituye un hecho ilícito de naturaleza continua o permanente68 y de carácter pluriofensivo, pues no solo produce una privación arbitraria de la libertad, sino que pone en peligro la integridad personal, la seguridad y la propia vida de la persona detenida. El carácter permanente y pluriofensivo de la desaparición forzada de personas se ve reflejado em los artículos II y III de la Convención Interamericana sobre Desaparición Forzada p. 10 25. En el caso sub judice, la Comisión solicitó al Tribunal que dicte una sentencia de fondo dando por establecidos los hechos "en razón de la importancia que El establecimiento de una verdad oficial de lo acontecido tiene para las víctimas de violaciones a los derechos humanos y en este caso para la sociedad guatemalteca em su conjunto". Los representantes reiteraron dicha solicitud e indicaron que las sentencias de este Tribunal son per se una forma de reparación y brindan "grandes aportes en los procesos de verdad y justicia”.

${ }^{371}$ Renato e Hugo Ticona Estrada foram detidos no dia 22 de julho de 1980 por uma patrulha militar, cujos agentes não se identificaram, tampouco disseram quais eram as razões da prisão. Ambos foram levados, agredidos e torturados. Depois de levados ao estabelecimento Dirección de Orden Público - DOP, foram separados, e Renato nunca mais foi encontrado. Hugo, muito enfermo, foi localizado por seus pais, e permaneceu preso até 4 de novembro de 1980. Caso Ticona Estrada e outros vs. Bolívia, sentença de mérito, reparação e custas, pp. 14-5, paras. 50-1.
} 
reparar os danos causados por meio da investigação do ocorrido e a punir os responsáveis ${ }^{372}$ pelos atos cometidos contra Renato e Hugo, devendo ainda localizar os restos mortais da vítima desaparecida, publicar em diário oficial e em meio de comunicação impresso de grande circulação partes da sentença, pagar indenizações de cunho moral e material aos familiares, bem como oferecer-lhes tratamento de saúde, e, por fim, criar as condições materiais para a implementação do Conselho Interinstitucional para o Esclarecimento dos Desaparecimentos Forçados $^{373}$.

No caso Anzualdo Castro vs. Peru ${ }^{374}$, julgado pela Corte em 22 de setembro de 2009, após encaminhamento pela Comissão em 11 de julho de 2008, foi considerado que houve violação aos arts. 1.1, 3, 4.1, 5.1, 5.2, 7.1, 7.6, 8, 13, 25.1 da Convenção Americana e arts. I e III da Convenção Interamericana sobre Desaparecimento Forçado pelo Estado peruano em prejuízo da vítima e seus familiares. Determinou que o Estado deveria prosseguir com as investigações e apurar os fatos e os responsáveis pelo desaparecimento da vítima, bem como sua busca e identificação, reformando sua legislação penal interna, a partir da tipificação do crime de desaparecimento forçado de pessoas, da implementação programa de educação em direitos humanos nos órgãos de segurança e forças armadas, da publicação da sentença no diário oficial, da admissão de sua responsabilidade neste caso mediante ato público, colocando uma placa no Museu da Memória em lembrança à vítima, com cerimonial e participação dos familiares. A Corte também fixou indenização de ordem material e moral aos familiares e exigiu que o Estado oferecesse tratamentos de saúde a eles ${ }^{375}$.

\footnotetext{
372 Caso Ticona Estrada e outros vs. Bolívia, sentença de mérito, reparação e custas, pp. 23-4, paras. 80. El deber de investigar en casos de desaparición forzada incluye necesariamente realizar todas las acciones necesarias para determinar el destino o paradero de la persona desaparecida. Al respecto, este Tribunal ha indicado que solo si se esclarecen todas las circunstancias en cuanto a la violación, el Estado habrá proporcionado a las víctimas y a sus familiares un recurso efectivo y habrá cumplido con su obligación general de investigar y eventualmente sancionar, permitiendo a los familiares de la víctima conocer la verdad, sobre lo sucedido a la víctima y su paradero.

81. Asimismo, esta Corte se ha referido al derecho que asiste a los familiares de las presuntas víctimas de conocer lo que sucedió y de saber quiénes fueron los responsables de los respectivos hechos. Los familiares de las víctimas tienen el derecho, y los Estados la obligación, de que lo sucedido a éstas sea efectivamente investigado por las autoridades del Estado; se siga un proceso contra los presuntos responsables de estos ilícitos; en su caso, se les impongan las sanciones pertinentes, y se reparen los daños y perjuicios que dichos familiares han sufrido.

${ }^{373}$ Caso Ticona Estrada e outros vs. Bolívia, sentença de mérito, reparação e custas, pp. 50-2, para. 188.

374 O Sr. Anzualdo Castro desapareceu em 16 de dezembro de 1993, por atos do serviço de inteligência do exército. Alega-se que a vítima foi levada aos sótãos do exército, onde foi executado, e seus restos incinerados nos fornos que existiam nesses sótãos. Caso Anzualdo Castro vs. Peru, sentença de mérito, reparação e custas, p. 2, para. 2.

${ }^{375}$ Caso Anzualdo Castro vs. Peru, sentença de mérito, reparação e custas, pp. 70-2, para. 239.
} 
Neste último caso julgado pela Corte, verifica-se a forma mais atual como esse tribunal vem analisando a questão do direito à verdade relacionado aos casos de desaparecimento forçado de pessoas $^{376}$, condenando o Estado e reparando as vítimas, extrai-se que em sua compreensão acerca do direito à verdade, como vinha sendo resolvido nos casos anteriores, há sua vinculação às garantias judiciais dos familiares da vítima, no sentido de que não saber seu paradeiro constitui trato cruel e degradante. Dessa maneira, o direito à verdade, nas decisões da Corte aos casos contenciosos de desaparecimento forçado de pessoas, não é direito autônomo, e sim vinculado aos arts. 8 e 25 da Convenção Americana. Em adição, considera que o direito a conhecer a verdade dos fatos significa importante reparação às vítimas, além de ser essencial para resolver a questão da impunidade, na medida em que saber os fatos e acontecimentos viabiliza a punição dos responsáveis pelas violações de direitos humanos.

376 Caso Anzualdo Castro vs. Peru, sentença de mérito, reparação e custas, pp. 38, 39, paras. 116-120: A. Sobre el derecho a conocer la verdad en casos de desapariciones forzadas

116. La Comisión alegó que el Estado es responsable por la violación del derecho a la verdad, que surge del derecho al acceso a la justicia, fundamentado en los artículos 1.1, 8, y 25 de la Convención Americana, al no cumplir con su deber de investigar, juzgar, y sancionar a los responsables de la desaparición forzada del señor Anzualdo Castro, en perjuicio de sus familiares, mientras se mantenga la incertidumbre sobre su paradero.

117. Los representantes, por su parte, alegaron que "la evolución del derecho internacional contemporáneo en el ámbito universal e interamericano apoya uma visión más amplia del derecho a la verdad, que otorga al mismo carácter de derecho autónomo y lo vincula a un rango más amplio de derechos", en su criterio, los contenidos en los artículos 1.1, 8, 13 y 25 de la Convención Americana. Alegaron que, en el presente caso, el Estado violó el derecho a la verdad de los familiares del señor Anzualdo Castro, por "las falencias en la investigación inicial, la inacción de las autoridades [...], la impunidad que todavía impera en el caso, y la ausencia de información sobre [su] paradero".

118. La Corte ha considerado el contenido del derecho a conocer la verdad en su jurisprudencia, en particular en casos de desaparición forzada. En el caso Velásquez Rodríguez la Corte afirmó la existencia de un "derecho de los familiares de la víctima de conocer cuál fue el destino de ésta y, en su caso, dónde se encuentran sus restos". En este tipo de casos se entiende que los familiares de la persona desaparecida son víctimas de los hechos constitutivos de la desaparición forzada, lo que les confiere el derecho a que los hechos sean investigados y que los responsables sean procesados y, en su caso, sancionados. La Corte ha reconocido que el derecho a conocer la verdad de los familiares de víctimas de graves violaciones de derechos humanos se enmarca en el derecho de acceso a la justicia. Asimismo, la Corte há fundamentado la obligación de investigar como una forma de reparación, ante la necesidad de reparar la violación del derecho a conocer la verdad en el caso concreto. El derecho a conocer la verdad también ha sido reconocido en diversosinstrumentos de Naciones Unidas y recientemente por la Asamblea General de la Organización de Estados Americanos (OEA).

119. El Tribunal considera que el derecho a conocer la verdad tiene como efecto necesario que en una sociedad democrática se conozca la verdad sobre los hechos de graves violaciones de derechos humanos. Esta es una justa expectativa que el Estado debe satisfacer142, por un lado, mediante la obligación de investigar las violaciones de derechos humanos y, por el otro, con la divulgación pública de los resultados de los procesos penales e investigativos. Esto exige del Estado la determinación procesal de los patrones de actuación conjunta y de todas las personas que de diversas formas participaron en dichas violaciones y sus correspondientes

responsabilidades. Además, en cumplimiento de sus obligaciones de garantizar el derecho a conocer la verdad, los Estados pueden establecer comisiones de la verdad, las que contribuyen a la construcción y preservación de la memoria histórica, el esclarecimiento de hechos y la determinación de responsabilidades institucionales, sociales y políticas en determinados períodos históricos de una sociedad.

120. Respecto de la alegada violación del artículo 13 de la Convención, los representantes se limitaron a señalar que el derecho a la verdad está vinculado "a um rango más amplio de derechos" y citaron varios instrumentos internacionales, informes al respecto y un caso ante la Comisión Interamericana, pero no lo vincularon a los hechos del presente caso. Consecuentemente, los elementos aportados resultan insuficientes para constatar la alegada violación de aquella disposición. 
A Comissão Interamericana de Direitos Humanos reconhece o direito à verdade como direito autônomo, e assim demanda à Corte nos casos de desaparecimento forçado. A Corte, por sua vez, compreende esse direito como vinculado aos direitos de investigação e punição dos responsáveis pela grave violação. Nesse sentido,

A Corte Interamericana de Direitos Humanos tem reconhecido reiteradamente o direito dos familiares das vítimas de desaparecimento forçado a conhecer sua sorte e seu paradeiro. A Corte Interamericana vinculou o direito à verdade ao direito da vítima e seus familiares de obterem uma explicação dos fatos relacionados com as violações e as correspondentes responsabilidades dos órgãos estatais competentes, mediante os procedimentos de investigação e julgamento que estabelecem no art. 8 (direito a ser ouvido por um tribunal competente, independente e imparcial) e no art. 25 (direito a um recurso efetivo e à proteção judicial) da Convenção Americana de Direitos Humanos. A Corte Interamericana considerou que o direito à verdade não se limitava aos casos de desaparecimento forçado, mas que se aplicava a qualquer tipo de violação manifesta de direitos humanos. A Corte assinalou que o direito à verdade também se baseava no dever de os Estados respeitarem e garantirem os direitos humanos e, em particular, de levar a sério uma investigação eficaz das violações multifacetadas de direitos humanos. ${ }^{377}$

\subsubsection{O caso brasileiro na Corte Interamericana de Direitos Humanos}

Em 26 de março de 2009, a Comissão de Direitos Humanos encaminhou o caso Julia Gomes Lund e outros (Guerrilha do Araguaia) vs. Brasil à Corte Interamericana de Direitos Humanos, solicitando que este tribunal aprecie o desaparecimento forçado de setenta pessoas e a execução extrajudicial de uma pessoa ${ }^{378}$, cometidos pelo Estado brasileiro entre 1972 e 1975, durante o regime militar instaurado no país, que ocorreu de 1964 a 1985. A Comissão pede à Corte que responsabilize o Brasil por violação aos arts. 1.1, 2, 3, 4, 5, 7, 8, 13, 25 da Convenção Americana, em razão de detenção arbitrária, tortura e desaparecimento dos membros do Partido Comunista do Brasil, e de camponeses da região. O Estado Brasileiro não realizou uma investigação penal visando a sancionar os responsáveis por tais violações

377 E/CN.4/2006/91, Estudo sobre direito à verdade da ONU: 30. La Corte Interamericana de Derechos Humanos (en adelante, la "Corte Interamericana") há reconocido reiteradamente el derecho de los familiares de las víctimas de desapariciones forzadas a conocer su suerte y su paradero. La Corte Interamericana vinculó el derecho a La verdad al derecho de la víctima o de sus familiares a obtener una explicación de los hechos relacionados con las violaciones y las correspondientes responsabilidades de los órganos estatales competentes, mediante los procedimientos de investigación y enjuiciamiento que se establecen en el artículo 8 (derecho a ser oído por un tribunal competente, independiente e imparcial) y en el artículo 25 (derecho a un recurso efectivo y a la protección judicial) de La Convención Americana sobre Derechos Humanos. La Corte Interamericana consideró que El derecho a la verdad no se limitaba a los casos de desapariciones forzadas sino que se aplicaba a cualquier tipo de violación manifiesta de los derechos humanos. La Corte subrayó que El derecho a la verdad también se basaba en el deber de los Estados de respetar y garantizar los derechos humanos y, en particular, de llevar a cabo una investigación eficaz de las violaciones manifiestas de los derechos humanos.

${ }^{378}$ Esta pessoa, Maria Lucia Petit, estava desaparecida até 1991, quando seus restos foram localizados, tendo sua identificação em 1996. 
em razão da lei de anistia. Além disso, os recursos de natureza civil para obter informações acerca dos fatos não foram efetivos, bem como as medidas legislativas e administrativas adotadas pelo Estado Brasileiro obstaram o direito de acesso às informações dos familiares das vítimas, de modo que essas restrições causaram danos à integridade pessoal dos familiares dos desaparecidos e da própria pessoa executada ${ }^{379}$.

A Comissão solicitou à Corte que condene o Brasil a adotar todas as medidas para que a lei de anistia não continue representando um óbice para a persecução penal dos crimes contra a humanidade, e, no mesmo sentido, solicita que julgue os responsáveis por tais crimes imprescritíveis, publique os resultados dessa persecução penal, e tipifique o crime de desaparecimento forçado em seu ordenamento interno, de acordo com os documentos internacionais. Pede também que determine ao país realizar as ações e modificações legais necessárias para sistematizar e publicar todos os documentos relacionados com a Guerrilha do Araguaia, que ofereça todos os recursos para localizar as vítimas desaparecidas, possibilitando uma reparação aos familiares das vítimas, com tratamento físico e psicológico, além da celebração de atos simbólicos. Ademais, propõe que o país implemente programas de educação em direitos humanos dentro das Forças Armadas, e trate desse caso em especial. ${ }^{380}$

A ditadura militar no Brasil inseriu-se em um contexto de Guerra Fria, a exemplo de seus vizinhos do Cone Sul (Paraguai em 1954, Brasil em 1964, Argentina em 1966 e 1976, Uruguai em 1973 e Chile em 1973), nos quais era comum a estratégia anti-comunista por meio da Doutrina de Segurança Nacional. Outro ponto comum das ditaduras foram as estratégias utilizadas para repressão à oposição, contendo em seu repertório os crimes contra a humanidade como a tortura, o desaparecimento forçado, as execuções extrajudiciais. ${ }^{381}$

No Brasil, durante a década de 1960, após a tomada de poder pelas Forças Armadas, uma nova Constituição foi adotada em 1967, e diversos Atos Institucionais foram decretados, tendo seu ápice com o AI-5 em 1968, evidenciando as reformas jurídicas ditatoriais, pois suprimiam liberdades e garantias individuais e coletivas, promoveram o fechamento do Congresso Nacional, a instituição de eleições indiretas, a proibição de habeas corpus em casos de crimes políticos contra a segurança nacional. Em 1970, o general Geisel, então no

379 Comissão de Direitos Humanos da OEA. Demanda perante a Corte Interamericana de Direitos Humanos, Caso 11.552 , p. 2, para. 6 .

${ }^{380}$ Idem, p. 3, para. 8.

${ }^{381}$ Idem, p. 15, para. 53. 
poder, determinou que Aeronáutica e Marinha estavam subordinadas ao Exército, que criou os Destacamentos de Operações de Informações, e o órgão colegiado Centro de Operações de Defesa Interna, formando assim os centros de repressão política, os DOI-CODI. Desse modo, paralelamente à criação desses aparelhos repressivos, a resistência também foi aumentando os movimentos de guerrilha urbana, e é nesse contexto que se organizou a Guerrilha do Araguaia. Esta guerrilha foi um fato ocorrido no início da década de 1970, quando membros do Partido Comunista do Brasil organizavam uma ação revolucionária, inspirada na Revolução Chinesa, que visava a envolver os camponeses na luta contra a ditadura militar, para então invadir as cidades e fazer frente a esse regime político. Contudo, as forças militares descobriram tal intenção e desapareceram com os guerrilheiros e camponeses que haviam se juntado a eles.

O caso ainda não foi julgado pela Corte, contudo, algumas ações em âmbito interno têm sido realizadas nesse contexto de trazer à tona a verdade ocorrida no período ditatorial, ações essas fruto da demanda da Comissão para a Corte, mas também de iniciativas das vítimas em associações, de organizações da sociedade civil e de instituições públicas. Dentre as medidas visando a revelar os acontecimentos do período em questão, tem-se a criação de delegação destinada a localizar os restos mortais de tais desaparecidos, o projeto de comissão de verdade advindo com o $3^{\circ}$. plano nacional de direitos humanos, e espera-se pronunciamento do Supremo Tribunal Federal acerca da matéria.

No que se refere ao exercício do direito à verdade no Brasil pós-ditadura militar, Perrone-Moisés aponta ter havido algumas iniciativas nesse sentido, contudo ressalva que "o exercício deste direito implica mais do que reconhecer uma morte ou indenizar vítimas.” Destaca também o fato de haver no país impedimentos para o pleno exercício do direito à verdade, expressos pela lei de anistia de 1979, que é contrária ao direito internacional, na medida em que anistiou os perpetradores de tortura, desaparecimento forçado e execuções sumárias - crimes contra a humanidade. Consequentemente impede o dever de investigar tais crimes pela lei que regula o acesso a arquivos (Lei 11.111/05), já que o Comitê de Direitos Humanos das Nações Unidas determinou a publicidade dos documentos referentes às graves violações de direitos humanos. O país não cumpriu tal obrigação no prazo estipulado. Dessa maneira, a autora relaciona a falta de investigações acerca da apuração dos fatos e circunstâncias das graves violações de direitos humanos com o exercício do direito à verdade no país. ${ }^{382}$

\footnotetext{
${ }^{382}$ PERRONE-MOISÉS. O exercício do direito à verdade no Brasil pós-ditadura militar. In BENEVIDES, Maria Victoria de Mesquita, BERCOVICI, Gilberto, MELO, Claudineu de. Direitos Humanos, Democracia e República: Homenagem a Fábio Konder Comparato. São Paulo: Quartier Latin, 2009, p. 273.
} 


\section{Memória e Direitos Humanos na América Latina}

A análise que se pretende desenvolver neste capítulo insere-se no marco da diferenciação proposta no capítulo anterior, em que se identificou a existência do direito à verdade para o Direito Internacional dos Direitos Humanos, sua relação com a possibilidade de justiça frente a crimes de direito internacional e graves violações de direitos humanos, e com o favorecimento de construção de memórias individuais que, compostas a outros elementos, também contribuem para a formação de memórias coletivas. Dessa maneira, o que será tratado é o significado da memória coletiva à luz da análise de teóricos da memória, sua relação com os desaparecidos e a construção identitária, envolvendo assim a relação da memória e os direitos humanos.

\subsection{Memória coletiva}

A memória que interessa a essa discussão é a constituída no campo das ciências humanas e sociais, em detrimento daquela do âmbito da psicologia, fisiologia, biologia, psiquiatria etc, relacionadas aos aspectos neurológicos do corpo humano - embora seu estudo em alguma dessas ciências possa ter relação com questões da memória histórica e social. Nesse sentido, "os fenômenos da memória, tanto nos seus aspectos biológicos como psicológicos, mais não são do que os resultados de sistemas dinâmicos de organização e apenas existem "na medida em que a organização os mantém ou reconstitui'". Por essa razão, diversos cientistas das ciências humanas e sociais aproximaram a questão da memória à linguagem, produto da sociedade. ${ }^{383}$ Nesse sentido, aponta Le Goff:

\footnotetext{
Ainda é mais evidente que as perturbações da memória, que, ao lado da amnésia, se podem manifestar também no nível da linguagem na afasia, devem, em numerosos casos, esclarecer-se também à luz das ciências sociais. Por outro lado, num nível metafórico, mas significativo, a amnésia é não só uma perturbação no indivíduo, que envolve perturbações mais ou menos graves da presença da personalidade, mas também a falta ou a perda, voluntária ou involuntária, da memória coletiva nos povos e nas nações, que pode determinar perturbações graves da identidade coletiva. $^{384}$
}

${ }^{383}$ LE GOFF, Jacques. História e Memória. Campinas: Unicamp, 5a. Ed., 2003, pp. 419-421.

${ }^{384}$ Idem, p. 421. 
Continua sua análise localizando a situação da memória na história da humanidade, e marca a atuação dos psicólogos e psicanalistas que

[...] insistiram, quer a propósito da recordação, quer a propósito do esquecimento [...], nas manipulações conscientes ou inconscientes que o interesse, a afetividade, $o$ desejo, a inibição, a censura exercem sobre a memória individual. Do mesmo modo, a memória coletiva foi posta em jogo de forma importante na luta das forças sociais pelo poder. Tornar-se senhores da memória e do esquecimento é uma das grandes preocupações das classes, dos grupos, dos indivíduos que dominaram e dominam as sociedades históricas. Os esquecimentos e os silêncios da história são reveladores destes mecanismos de manipulação da memória coletiva. ${ }^{385}$

Para se tratar da história da memória coletiva, e sua relação com a história, com o fim de compreender seu papel e significado no desenvolvimento das sociedades em termos de valores e princípios, será adotado o desenvolvimento efetuado por Le Goff, a partir da classificação de Leroi-Gourhan, que propõe dividir os períodos em que predominava a transmissão oral, a transmissão escrita com tábuas ou índices, as fichas simples a mecanografia e a seriação eletrônica ${ }^{386}$.

Nas culturas sem escrita, "a acumulação de elementos de memória faz parte da vida cotidiana" 387 , e tem como fundamentos a "transmissão de conhecimentos considerados secretos" e o estímulo ao desenvolvimento de uma memória mais criadora que repetitiva ${ }^{388}$. Nessa realidade, as memórias coletivas são fundadas nos mitos de origem, criando a história ideológica, para usar a terminologia de $\mathrm{Nadel}^{389}$, que se pode compreender como os valores mínimos em que essas sociedades se organizam. Ou seja, a memória coletiva dessas sociedades, no que se refere a seus princípios, tem como base os mitos das origens, que sustentam a tradição. Há a outra memória relacionada à história objetiva, que seriam aqueles fatos objetivos, relacionados aos momentos de mudança da sociedade. Para a transmissão de ambas as histórias há os especialistas da memória, os guardiões que se tornam figuras importantes para manter a coesão da sociedade. O que se observa, todavia, é que a transmissão dessa memória coletiva por meio oral não se faz de forma exata, mas pela narrativa e interação, de modo que a principal prática de memorização é o canto, atribuindo “à

\footnotetext{
385 Idem, p. 422.

386 Idem, p. 423. Para conferir mais acerca do trabalho de Leroi Gourhan, cuja obra é referência para a construção do conceito de memória coletiva para Le Goff, ver Le geste e La parole. Paris: Michel, 2 vols, $1964-$ 65 .

${ }^{387}$ Idem, p. 424. Goody Apud Le Goff.

${ }^{388}$ Idem, p. 426

${ }^{389}$ Idem, p. 424. Para conferir o trabalho de Nadel a que Le Goff faz referência, ver A Black byzantium. The kingdom of Nupe in Nigeria. Londres: Oxford University Press, 1942.
} 
memória mais liberdade e mais possibilidades criativas" ${ }^{390}$. Quanto à memória coletiva relativa aos conhecimentos práticos e técnicos, eles são ensinados em âmbito privado e secreto, de acordo com as "células sociais da etnia",391.

Quando nas sociedades antigas aparece a escrita, inicia-se uma grande transformação na memória coletiva, pois permite a "comemoração, a celebração através de um monumento comemorativo de um acontecimento memorável" ${ }^{392}$, e a outra a elaboração de documentos em suportes específicos para tanto, adquirindo então duas funções, a de registro de informações comunicando tempo e espaço, e a possibilidade de resignificar os fatos pela passagem da esfera auditiva para a visual. ${ }^{393}$ Essa mudança do caráter da memória, além do aparecimento da escrita como forma de elaborá-la, também está associada ao desenvolvimento urbano, já que as estruturas públicas passam a desenvolver "programas de memorização", e a construírem "instituições-memória" tais quais museus, arquivos, bibliotecas, criadas pelo rei com o objetivo de narrar seus feitos, "levando à fronteira onde a memória se torna história”"394.

Chegando a Grécia Antiga, nota-se uma evolução da história para a memória coletiva e, "da mesma forma que a memória escrita vem acrescentar-se à memória oral, transformando-a, a história vem substituir a memória coletiva, transformando-a, mas sem destruí-la”395. As mudanças nas estruturas sociais vão acontecendo à medida que a memória vai ganhando outros contornos, como na esfera jurídica, quando a memória passa a ser elemento chave para uma decisão de justiça. ${ }^{396}$ No entanto, Le Goff assinala:

É necessário, finalmente, não esquecer que, ao lado da emergência espetacular da memória no seio da retórica, quer dizer, de uma arte da palavra ligada à escrita, a memória coletiva prossegue o seu desenvolvimento através da evolução social e

\footnotetext{
${ }^{390}$ Idem, p. 426.

${ }^{391}$ Idem, p. 425.

392 Idem, p. 427.

${ }^{393}$ Idem, pp. $428-9$

${ }^{394}$ Idem, p. 429-430.

395 Idem , p. 432

396 "A instituição do mnemon, entendidos como funcionários da memória, lembra os fenômenos que já evocamos: a relação com o mito, com a urbanização. Na mitologia e na lenda, o mnemon é o servidor de um herói que o acompanha sem cessar, para lembrar-lhe uma ordem divina cujo esquecimento traria a morte. Os mnemones são utilizados pelas cidades como magistrados encarregados de conservar na memória o que é útil em matéria religiosa e jurídica. Com o desenvolvimento da escrita essas 'memórias vivas' transformam-se em arquivistas." Idem, p. 433. Os gregos fizeram da memória uma deusa, Mnemosine, (mãe de todas as musas, conhece os segredos da beleza, do saber, da justiça e da verdade) que, "revelando ao poeta os segredos do passado, o introduz nos mistérios do além (...) [a memória] é o antídoto do Esquecimento. No inferno órfico, o morto deve evitar ir à fonte do esquecimento, não deve beber no Letes (esquecimento), mas, ao contrário, nutrirse da fonte da Memória, que é uma fonte de Imortalidade.” Idem , p. 434
} 
política do mundo antigo. Veyne sublinhou a confiscação da memória coletiva pelos imperadores romanos, nomeadamente pelo meio do monumento público e da inscrição, nesse delírio da memória epigráfica. Mas o Senado romano, angariado e por vezes dizimado pelos imperadores, encontra uma arma contra a tirania imperial. É a damnatio memoriae, que faz desaparecer o nome do imperador defunto nos documentos de arquivo e das inscrições monumentais. Ao poder pela memória corresponde a destruição da memória. ${ }^{397}$

Durante a Idade Média, a memória esteve plenamente associada à difusão do cristianismo como religião e no monopólio intelectual da Igreja. O cristianismo e judaísmo são essencialmente religiões da recordação, porque o culto se dá aos atos divinos do passado, e o livro sagrado consiste em remontar uma tradição histórica, além da lembrança ser tarefa religiosa fundamental. Desse modo, os traços mais característicos das mudanças da memória nessa época estão relacionados à sua cristianização, à

repartição da memória coletiva entre uma memória litúrgica girando em torno de si mesma e uma memória laica de fraca penetração cronológica, desenvolvimento de uma memória dos mortos, principalmente dos santos, papel da memória no ensino que articula o oral e o escrito, aparecimento dos tratados de memória. ${ }^{398}$

Assim, a memória cristã apresenta-se sobretudo na comemoração de Jesus, mas também na memória dos santos e dos mortos. A exemplo disso estão os mártires, que depois de sua morte tornavam-se memórias dos cristãos, nos obituários e nos seus túmulos, pois estes eram construídos nos centros das igrejas, e a comemoração dos santos se dava no dia de sua morte ou martírio. Além disso, a Igreja instituiu formas de lembrar os seus fiéis, com o obituário, e também de cultuar os mortos por meio de orações em sua memória, de modo que os pagãos e indignos ficavam fora dos obituários e das orações, caindo ao esquecimento daquela comunidade. Tanto a memória dos mortos era relevante que, no século IX foi declarado o dia dos finados, em 2 de novembro, momento de lembrar todos os fiéis mortos. ${ }^{399}$

Nessa época a memória foi objeto de reflexão no âmbito da teologia e da retórica ${ }^{400}$. Dessa maneira, na Idade Média a memória tinha relevante papel no mundo social, cultural e escolástico. Com a expansão das cidades, passou-se a criar os arquivos urbanos, sendo que essa memória urbana constituía importante fonte para as instituições, tornando-se essencial

\footnotetext{
${ }^{397}$ Idem, p. 437.

${ }^{398}$ Idem, p. 438.

${ }^{399}$ Idem, pp. 441-443

${ }^{400}$ Em 1235 Boncompagno da Signa (Apud Le Goff, p. 447) escreveu sobre a retórica, com atenção à memória, e assim a definiu: "A memória é um glorioso e admirável dom da natureza, através do qual reevocamos as coisas passadas, abraçamos as presentes e contemplamos as futuras, graças à sua semelhança com as passadas”.
} 
para a afirmação da identidade coletiva e comunitária ${ }^{401}$. Durante o Renascimento, com a imprensa ${ }^{402}$ ganhando força nos cenários públicos, a memória transformou-se no século XIV em burocrática, e passou a servir à administração monárquica. Nos séculos seguintes, começou-se a desenvolver a memória jornalística, em que aparece na cena pública as opiniões públicas, que também passam a construir suas memórias. Além disso, há uma publicação massiva de dicionários e enciclopédias, para uso de todos, que contém a memória de tudo que existia no mundo ${ }^{403}$.

Com a Revolução Francesa, enquanto a memória científica e intelectual vinha ganhando cada vez mais força e notoriedade com acesso a todos, nota-se um lugar de esquecimento relegado à memória dos mortos, quase como se tentasse eliminar a morte na Idade das Luzes. Logo em seguida, no século XIX há o retorno ao culto e à lembrança dos mortos, "o romantismo acentua a atração do cemitério ligado à memória", também em função da valorização dos sentimentos em detrimento do saber-razão característico do século anterior ${ }^{404}$. Na mesma medida, as comemorações ressurgem na França, para recordar a Revolução Francesa, por meio de festas. No entanto, logo aparece a manipulação da memória, e nas festas comemorativas a censura disputa com a memória, face ao 9 de Termidor, em que os massacres, multiplicidade de vítimas e exceções do Terror são subtraídos da memória coletiva nas comemorações ${ }^{405}$.

A partir desse século a comemoração ganha outros símbolos, como moedas, medalhas, selos de correio, monumentos, placas de parede, inscrições nas casas de mortos ilustres. "Ao mesmo tempo, o movimento científico, destinado a fornecer à memória coletiva das nações os monumentos de lembrança acelera-se" ${ }^{\text {406 }}$. Diversos Estados europeus criaram seus arquivos

\footnotetext{
${ }^{401}$ Idem, pp. 444-445

402 Assim Leroi-Gourhan (Apud Le Goff, p. 452) "caracterizou bem esta revolução da memória pela imprensa: Até o aparecimento da imprensa [...] dificilmente se distingue entre a transmissão oral e a transmissão escrita. A massa do conhecido está mergulhada nas práticas orais e nas técnicas; a área culminante do saber, com um quadro imutável desde a Antiguidade é fixada no manuscrito para ser aprendida de cor [...] Com o impresso [...] não só o leitor é colocado em presença de uma memória coletiva enorme, cuja matéria não é mais capaz de fixar integralmente, mas é frequentemente colocado em situação de explorar textos novos. Assiste-se então à exteriorização progressiva da memória individual; é do exterior que se faz o trabalho de orientação que está escrito no escrito."

${ }^{403}$ Idem , pp. $451-456$

${ }^{404}$ Idem , p. 456

${ }^{405}$ Idem , p. 457. "Se os revolucionários querem festas comemorando a revolução, a maré da comemoração é, sobretudo, apanágio dos conservadores e ainda mais dos nacionalistas, para quem a memória é um objetivo e um instrumento de governo. Ao 14 de julho republicano a França católica e nacionalista acrescenta a celebração de Joana D’Arc. A comemoração do passado atinge o auge na Alemanha nazista e na Itália fascista.” Idem, p. 458. ${ }^{406}$ Idem, p.458
} 
nacionais, iniciando uma nova fase pública de acesso e publicidade à memória histórica, assim como os museus nacionais começaram a ser abertos. Dois fenômenos merecem atenção nesse borbulho de produção de memória coletiva; a fotografia, no século XIX, que "revoluciona a memória: multiplica-a e democratiza-a, dá-lhe uma precisão e uma verdade visuais nunca antes atingidas, permitindo, assim, guardar a memória do tempo e da evolução cronológica."; e os monumentos aos mortos construídos após a Primeira Guerra Mundial, "em numerosos países é erigido um Túmulo ao Soldado Desconhecido, procurando ultrapassar os limites da memória, associada ao anonimato, proclamando sobre um cadáver sem nome a coesão da nação em torno da memória comum". ${ }^{407}$

$\mathrm{Na}$ contemporaneidade, com o advento da memória eletrônica, os computadores, surge um novo contraponto à reflexão acerca da memória. Enquanto aquela é estável, a memória humana é maleável, flexível, relacionada com afetos, imaginação, para além da razão que a eletrônica consegue armazenar. Nesse sentido, essa memória é um auxiliar da memória e do espírito humano ${ }^{408}$. A despeito desse novo elemento que surge no século XX, e coloca a questão da memória em análise, "a memória coletiva sofreu grandes transformações com a constituição das ciências sociais e desempenha um papel importante na interdisciplinaridade que tende a instalar-se entre elas" ${ }^{409}$.

Memória coletiva, dessa maneira, pode ser definida como "o que fica do passado no vivido dos grupos, ou o que os grupos fazem do passado" ${ }^{410}$. Nesse sentido, apesar de a história sempre ter se confundido com memória, e aquela ter se desenvolvido a partir da rememoração, anamnese e memorização, o esforço da nova história científica é por criá-la a partir da memória coletiva, e ser informada nos lugares da memória coletiva ${ }^{411}$. Assim, "a

\footnotetext{
${ }^{407}$ Idem, p. 460

${ }^{408}$ Idem, pp. 462-3

${ }^{409}$ Idem, p. 466. "Pesquisa, salvamento, exaltação da memória coletiva não mais nos acontecimentos mas ao longo do tempo, busca dessa memória menos nos textos do que nas palavras, nas imagens, nos gestos, nos ritos e nas festas; é uma conversão do olhar histórico. Conversão partilhada pelo grande público, obcecado pelo medo de uma perda de memória, de uma amnésia coletiva, que se exprime desajeitadamente na moda retrô, explorada sem vergonha pelos mercadores de memória desde que a memória se tornou um dos objetos da sociedade de consumo que se vende bem."

${ }^{410}$ Idem, p. 467, grifos nossos. Ver definição de Pierre Nora em "Mémoire Collective", In LE GOFF et al. (org.) La nouvelle histoire. Paris: Retz, 1978.

${ }^{411}$ Idem , p. 467. São lugares da memória coletiva "topográficos, como os arquivos, bibliotecas e museus; monumentais, como os cemitérios e arquiteturas; simbólicos como as comemorações, peregrinações, aniversários e emblemas; funcionais, como manuais, autobiografias ou associações; [...] os criadores e denominadores da memória coletiva: Estados, meios sociais e políticos, comunidades de experiências históricas ou de gerações, levadas a constituir os seus arquivos em função dos usos diferentes que fazem da memória”. Ver NORA, Pierre.Les lieux de mémoire. Paris: Gallimard, 1985.
} 
memória é um elemento essencial do que se costuma chamar de identidade, individual ou coletiva, cuja busca é uma das atividades fundamentais dos indivíduos e das sociedades de hoje, na febre e na angústia."

Desse modo, a duração e existência da memória coletiva se apóiam nos grupos, nos conjuntos de pessoas que lembram, sendo que os fatos lembrados por cada pessoa não têm a mesma intensidade para cada um, "cada memória individual é um ponto de vista sobre a memória coletiva, e este ponto de vista muda segundo o lugar que ali ocupo e que esse mesmo lugar muda segundo as relações que mantenho com outros ambientes." ${ }^{413}$ Assim, ao indivíduo correspondem dois tipos de memórias, as suas próprias individuais, e as coletivas, sendo que essas abarcam as memórias dos grupos a que faz parte, portanto o indivíduo dentro do grupo também experienciou tais acontecimentos do passado e é capaz de reconstituí-los no presente, e aquelas que dizem respeito à memória histórica, que o indivíduo toma conhecimento porque lhe foi dito, ou quando ele investiga os fatos que ocorreram no passado, mas que não foram por ele vividos. ${ }^{414}$

A memória, a princípio, parece ser algo individual, íntimo, da pessoa. Contudo, como visto em Halbwachs ${ }^{415}$, a memória deve ser entendida sobremaneira como um fenômeno coletivo e social, que é construída coletivamente e submetida a mudanças constantes e transformações, mas, mesmo considerando essa característica mutável da memória, elas têm algo de invariável, guardam em si elementos invariáveis. Nesse sentido, os elementos constitutivos da memória são os acontecimentos vividos individualmente somados aos vividos no tempoespaço pelo grupo ou coletividade a qual a pessoa pertence. Para além dos acontecimentos, a memória também se constitui de pessoas e personagens, daquelas que passaram pela vida individual da pessoa, mas também que fizeram parte do tempo-espaço indiretamente do transcurso de vida dessa pessoa. O terceiro elemento componente da formação de memória são os lugares de memória, relacionados a lembranças que podem ser privadas ou públicas, tais como os atos comemorativos, os monumentos a mortos ${ }^{416}$. Assim, dessa tensão que parece surgir nesse campo de produção de memórias entre a coletiva e individual, depreendese que as individuais não devem se opor ou se anular, mas que todas têm seu espaço na

\footnotetext{
${ }^{412}$ Idem, p. 469.

${ }^{413}$ HALBWACHS, Maurice. A memória coletiva. São Paulo: Centauro, 2006, p. 69.

${ }^{414}$ Idem, P. 69-70.

${ }^{415}$ Idem, pp. 29-70.

${ }^{416}$ POLLAK, Michael. Memoria, olvido, silencio. La producción social de identidades frente a situaciones limite. La Plata: Ediciones Al Margen, 2006, pp. 34-5.
} 
produção coletiva, e podem se conciliar e se informar alimentando uma base comum, que seria a coletiva.

Dessa forma, o outro tipo de memória componente da memória coletiva é a memória histórica ou social, que se ampara nos acontecimentos históricos, e daquilo que sabemos por que passou a humanidade, por meio de leituras, monumentos, referente aos fatos de que um indivíduo não pode lembrar porque não os viveu, de forma que não pode ter em si sua memória individual, na medida em que não participou do ocorrido. Assim, a memória histórica "só representaria para nós o passado sob uma forma resumida e esquemática, ao passo que a memória da nossa vida nos apresentaria dele um panorama bem mais contínuo e denso." ${ }^{417}$ No mesmo sentido, "a história parece um cemitério em que o espaço é medido e onde a cada instante é preciso encontrar lugar para novas sepulturas."

Assim, a memória coletiva não se confunde com a história, como por vezes é comum se associar. "A história é a compilação dos fatos que ocuparam maior lugar na memória dos homens" ${ }^{419}$, de modo que ela se inicia quando termina a tradição, em que se irrompe a memória histórica ou social. A história começa a ser escrita quando já não há mais nenhuma testemunha viva para relatar suas lembranças, ou qualquer grupo na mesma conformação quando da formação das memórias dos acontecimentos, como explica Halbwachs:

Se a condição necessária para que exista a memória é que o sujeito que lembra, indivíduo ou grupo, tenha a sensação de que ela remonta a lembranças de um movimento contínuo, como poderia a história ser uma memória, se há uma interrupção entre a sociedade que lê essa história e os grupos de testemunhas ou atores, outrora, de acontecimentos que nela são relatados? É claro, um dos objetivos

\footnotetext{
${ }^{417}$ HALBWACHS, Maurice. A memória coletiva. São Paulo: Centauro, 2006, p. 73. Pode-se compreender então que a memória coletiva contém em si três tipos de memória: individual, coletiva (o que se resolveu chamar de stricto sensu para fins de compreensão da autora) e histórica, sendo que a primeira diz respeito às lembranças que cada pessoa pode ter acerca dos fatos por que passou, a segunda refere-se àquilo por que a pessoa passou, inserida em um grupo, de modo que as memórias individuais e coletivas stricto sensu se alimentam e complementam, e a histórica, aquela por que o indivíduo não passou, mas é informado a partir de outras fontes que não suas próprias lembranças. A composição de todas essas memórias forma as memórias coletivas dos grupos, das sociedades, das pessoas. Nesse sentido, Halbwachs afirma "como a lembrança reaparece em função de muitas séries de pensamentos coletivos emaranhados e porque não podemos atribuí-la exclusivamente a nenhuma, imaginamos que é independente delas e contrapomos sua unidade à sua multiplicidade. É como acreditar que um objeto pesado, suspenso no ar por uma porção de fios tênues e entrecruzados, permaneça suspenso no vazio, e ali se sustenta”, Idem, p. 70. Assim, distinguir as memórias constitui-se esforço exclusivamente para compreensão, porque, na verdade, todas elas constituem-se conjuntamente, de forma complexa e não linear.

${ }^{418}$ Idem, p. 74. "Nossa memória não se apóia na história aprendida, mas na história vivida. Por história, devemos entender não uma sucessão cronológica de eventos e datas, mas tudo o que faz com que um período se distinga dos outros, do qual os livros e as narrativas em geral nos apresentam apenas um quadro muito esquemático e incompleto." Idem, p. 78-9.

${ }^{419}$ Idem, p. 100.
} 
da história talvez seja justamente lançar uma ponte entre o passado e o presente, e restabelecer essa continuidade interrompida" 420

Nessa perspectiva, Halbwachs define a memória coletiva de forma diversa da história porque ela guarda os interesses dos grupos, exclusivamente, e só retém do passado aquilo que ainda faz sentido para eles, configurando-se em uma "corrente de pensamento contínuo"421. Há, então, uma complexidade na formação das memórias coletivas que se instauram e conformam-se a depender das atualizações pelas quais passam os grupos, diferentemente da história que apresenta divisões na corrente dos fatos, mostra os momentos de ruptura e início dos períodos. Não há linhas claras acerca dos fatos para a memória coletiva como na história, somente limites irregulares e incertos. ${ }^{422}$ "A memória de uma sociedade se estende até [...] onde atinge a memória dos grupos de que ela se compõe. Não é por [...] indiferença que ela esquece uma quantidade de fatos e personalidades antigas, é porque os grupos que guardavam sua lembrança desapareceram."423

A outra razão porque a história se distingue da memória coletiva é o fato de esta última existir em multiplicidade. Ou seja, há muitas memórias coletivas, enquanto história há uma só. “[...] as próprias divisões que separam os países são fatos históricos, com o mesmo peso dos outros. Está tudo no mesmo plano. O mundo histórico é como um oceano para onde afluem todas as histórias parciais." ${ }^{424}$ Ele entende a vida humana ou as histórias dos acontecimentos humanos de maneira a apresentar o conjunto dos acontecimentos, em que a relação com o tempo e duração distancia-se sobremaneira das memórias coletivas. Nesse bojo:

Para que se possa falar de memória, é preciso que as partes do período sobre o qual ela se estende sejam diferenciados em certa medida. Cada um dos grupos tem uma história. Neles distinguimos personagens e acontecimentos - mas o que chama nossa atenção é que, na memória, as semelhanças passam para o primeiro plano. No momento em que examina seu passado, o grupo nota que continua o mesmo e toma consciência de sua identidade através do tempo. A história, como já dissemos, deixa passar esses intervalos em que aparentemente nada acontece, em que a vida se limita a se repetir, sob formas um tanto diferentes, mas sem alteração essencial, sem

\footnotetext{
${ }^{420}$ Idem, p. 101.

${ }^{421}$ Idem, p. 102.

${ }^{422}$ Idem, p. 104. "Os historiadores não podem levar a sério essas linhas de separação, e imaginar que elas tenham sido observadas pelos que viviam durante os anos que elas atravessam, como o personagem de uma comédia que grita: 'Hoje começa a guerra dos cem anos!' Quem sabe se, depois de uma guerra, de uma revolução, que tenha escavado um fosso entre duas sociedades, como se houvesse desaparecido uma geração intermediária, a sociedade jovem ou a parte jovem da sociedade, em harmonia com a porção idosa, não se preocupa principalmente em apagar os traços dessa ruptura, em reaproximar gerações extremas, e apesar de tudo manter a continuidade da evolução? É preciso que a sociedade viva; mesmo que as instituições sociais estejam profundamente transformadas, e então, sobretudo quando estiverem, o melhor meio de fazer com que elas criem raízes é fortalecê-las com tudo o que se puder aproveitar de tradições".

${ }^{423}$ Idem, p. 105.

${ }^{424}$ Idem, p. 106.
} 
ruptura nem perturbação. Mas o grupo que vive no primeiro instante e, sobretudo, para si mesmo, visa perpetuar os sentimentos e as imagens que formam a substância do seu pensamento. É o tempo decorrido, durante o qual nada o modificou profundamente, que ocupa o maior espaço em sua memória. ${ }^{425}$

No mesmo sentido, Pollak ${ }^{426}$ afirma que a partir dos lugares de memória é possível identificar a memória coletiva de determinado grupo, figurando-se como pontos de referência daquilo que fundamenta e reforça os laços sociais, suas características, hierarquias, sentimentos de pertencimento. Ademais, a partir de sua leitura de Halbwachs ${ }^{427}$, assinala que a função da memória coletiva, a despeito de compreendê-la como forma de dominação ou violência simbólica, é capaz de revigorar a coesão social, a partir da adesão afetiva ao grupo, gerando assim, uma comunidade afetiva.

Alerta Pollak, no entanto, que tem dominado na cena pública uma disputa de memórias, na medida em que se chocam as individuais ou de grupos minoritários com a dita oficial ${ }^{428}$. Assim, a linha tênue entre o que se pode dizer ou não, o que se pode confessar ou não, separa uma memória subterrânea de alguns nichos da sociedade da memória coletiva organizada pelo que o Estado deseja impor ou transmitir. A partir de três exemplos de silenciamento após situações-limite $^{429}$, Pollak aponta que todos têm em comum o fato de manterem-se vivas por dezenas de anos nas memórias familiares, nas redes afetivas, e passarem despercebidas pela sociedade em geral, e que, a conseqüência dessa espera por um lugar público onde possam ser transmitidas, é manterem-se intactas ${ }^{430}$. A função de se trabalhar a memória é que

\footnotetext{
425 Idem, p. 108.

${ }^{426}$ POLLAK, Michael. Memoria, olvido, silencio. La producción social de identidades frente a situaciones limite. La Plata: Ediciones Al Margen, 2006, pp. 17-8.

${ }^{427}$ Para ver a edição citada por Pollak: HALBWACHS, Maurice. La mémoire collective. Paris: PUF, 1968.

${ }^{428}$ POLLAK, Michael. Memoria, olvido, silencio. La producción social de identidades frente a situaciones limite. La Plata: Ediciones Al Margen, 2006, p. 18.

${ }^{429} \mathrm{O}$ primeiro exemplo refere-se à denúncia dos crimes stalinistas feita por Nikita Kruschev, marcando a primeira etapa de desestanilização, que possibilitou a ascensão de uma memória clandestina de dominação e repressão ao cenário público. Aqui Pollak evidencia como as memórias subterrâneas esperam décadas para virem à tona, como se aguardassem um momento propício, embora sempre tivessem sido tecidas e transmitidas no seio privado. O segundo exemplo diz respeito ás memórias dos sobreviventes de campos de concentração, que voltaram a Alemanha e Áustria, e calaram-se frente à lembrança traumática. A hipótese do autor deita-se sobre a ausência de campos de escuta, devido especialmente à responsabilidade que todos tinham frente ao nazismo. Contudo, quarenta anos depois, aqueles que viveram quiseram narrar no ambiente público suas memórias para as futuras gerações, pois sabiam que não podiam deixar apagar suas memórias se ficassem exclusivamente em suas lembranças individuais. O último exemplo de silenciamento é a deserdação e desobediência de um recrutamento forçado de soldados alsacianos ao exército alemão. Após a guerra, veio o questionamento do grau de comprometimento desses soldados - apesar de terem sido forçosamente recrutados, mostrando como uma situação ambígua pode também gerar silêncios. Idem, pp. 19-23.

${ }^{430}$ Idem, p. 24.
} 
A memória, essa operação coletiva dos acontecimentos e das interpretações do passado que se quer salvaguardar, se integra em tentativas mais ou menos conscientes de definir e reforçar sentimentos de pertencimento e fronteiras sociais entre coletividades de diversos tamanhos; partidos, sindicatos, igrejas, aldeias, regiões, clãs, famílias, nações etc. A referência ao passado serve para manter a coesão dos grupos e das instituições que compõem uma sociedade, para definir seu lugar respectivo, sua complementaridade, mas também as oposições irredutíveis. ${ }^{431}$

A memória coletiva, todavia, não é apenas uma conquista, mas objeto de poder, de modo que os arquivos sempre estão sob os auspícios dos governantes, embora seja necessário também controlar a mídia, que compõe com os arquivos para a produção dessa memória. Por essa razão, "a memória, na qual cresce a história, que por sua vez a alimenta, procura salvar o passado para servir ao presente e ao futuro. Devemos trabalhar de forma que a memória coletiva sirva para a libertação e não para a servidão dos homens". 432

\subsection{Memória e desaparecimento}

Diante dessa compreensão acerca das memórias coletivas que se fazem em confluência com as memórias individuais, de modo a criar novas situações públicas e políticas, surgiram no cenário público nas décadas de 1960 e 1970 novos grupos de pessoas, os familiares de desaparecidos. Juntos, eles reivindicam o reconhecimento da existência desse novo "sujeito social", o desaparecido, buscam saber a verdade dos fatos e o paradeiro de seus entes desaparecidos, demandam justiça e reparação frente aos atos cometidos pelo Estado ou com sua aquiescência. Vão, dessa maneira, organizando-se de modo a constituírem-se grupos cujos interesses pautam-se na possibilidade de clarificar no presente os acontecimentos, mas sobretudo de lembrarem seus desaparecidos não só em seus espaços privados, mas no cenário público. É como se, ao não esquecerem dos seus desaparecidos, essas pessoas obtivessem uma forma de reparação, de amenizar sua dor. Assim, saber a verdade dos fatos diz respeito a todos também, na medida em que todos fazem parte da humanidade, e essa questão faz parte dos assuntos humanos. Desse modo, o surgimento da figura do desaparecido dispara questões

\footnotetext{
${ }^{431}$ Idem, p. 25: La memória, esa operación colectiva de los acontecimientos y de las interpretaciones del pasado que se quiere salvguardar, se integra em tentativas más o menos conscientes de definir y reforzar sentimientos de pertenencia y fronteras sociales entre colectividades de distintos tamaños: partidos, sindicatos, Iglesias, aldeãs, regiones, clanes, famílias, naciones etc. La referencia al pasado sirve para mantener La cohésion de los grupos y las instituciones que componen uma sociedad, para definir su lugar respectivo, su complementariedad, pero también las oposiciones irreductibles.

${ }^{432}$ LE GOFF, Jacques. História e Memória. Campinas: Unicamp, 5a. Ed., 2003, p. 471, grifos nossos.
} 
nos grupos e sociedades de forma a colocar toda uma sociedade a lidar com essa questão, cada grupo a sua maneira. Reflete acerca disso Catela:

\begin{abstract}
Na Argentina contemporânea, o desaparecido passou a 'existir' como uma noção de pessoa que, por ter surgido de um estado de terror impensável, é, até o presente, essencialmente paradoxal. Sua simples enunciação obriga a realizar uma passagem dos anos 70 até a atualidade e a mapear a posição de quem a emite. A complexa tensão deste campo de visões ou de pontos de vista a transforma em uma noção de várias camadas e clivagens, que oscila em uma dualidade de idéias e sensações, tais como a vida e a morte, o conhecido e o desconhecido, a luminosidade e a escuridão. Ao delimitá-la, os agentes apagam certas caracterizações e inventam outras, expressam uma mistura de emoções e afirmações políticas. Em tudo isto estão enraizados a riqueza, o horror, a utilidade e a eficácia da palavra desaparecido. ${ }^{433}$
\end{abstract}

Considerando que a figura do desaparecido impõe aos familiares novas formas de elaboração do acontecido ${ }^{434}$ - diferentemente da morte ${ }^{435}$ - se faz necessário compreender que tipos de espaços e rituais passam a se constituir no cenário público no sentido de construção de memórias. Há uma ruptura na ritualística destinada à morte, e uma mudança no tempo destinado à elaboração do luto ${ }^{436}$ - por mais individual e singular que possa ser essa experiência. A diferenciação que se estabelece é no sentido de que o desaparecido como nova categoria de sujeito, não teve sua morte consumada, causando aos familiares novas formas de ritualizar essa situação, por meio de denúncia, inserindo o debate acerca da sorte do desaparecido na esfera pública, além de por muitos anos esperarem a volta do ente querido, buscarem pistas e informações relativas ao ocorrido, abrindo espaços públicos de debate em

433 CATELA, Ludmila da Silva. Situação limite e memória: reconstrução do mundo dos familiares de desaparecidos da Argentina. São Paulo: Hucitec/ Anpocs, 2001, pp. 202-3. No mesmo sentido, Azzali constata: [...] la constitución del desaparecido como sujeto de la legalidad no necesita dar cuenta de la existencia de su próprio cuerpo, su fuerza y esencia consiste en la historia que atestigua, en el acto de rescate de la memoria colectiva. AZZALI, Javier Carlos. Memoria colectiva y discurso jurídico. In Revista Crítica Jurídica, n. 20, janjul 2002, p. 35.

${ }^{434}$ Palavra de ordem defendida pelas Madres de Plaza de Mayo: Aparición con vida. Con vida los llevaram, con vida los queremos, com grande impacto simbólico, frente à manifestação de Emilio Mignone em 1980, que afirmou estarem os desaparecidos da Argentina todos mortos, sem especificar lugar, razão etc. CATELA, Ludmila da Silva. Situação limite e memória: reconstrução do mundo dos familiares de desaparecidos da Argentina. São Paulo: Hucitec/ Anpocs, 2001, p. 146-7.

${ }^{435}$ Idem, p. 141"Como fato social, a morte gera uma modificação no tempo e no espaço do grupo social afetado. Estas mudanças têm como referência principal as obrigações, os comportamentos e os ritos religiosos ou seculares que, por um determinado período, provocam uma espécie de intensificação dos sentimentos, emoções e estados corporais. O tempo e o espaço se concentram e, como em uma espiral, se tornam profundos e intensos. $\mathrm{O}$ que acontece quando este tempo-espaço não pode concentrar-se, quando se estende por anos, se mescla com a vida cotidiana, se dispersa ou se concentra em períodos que não estão diretamente relacionados com o momento da morte?"

${ }^{436}$ Para Ricouer, em sua leitura de Freud, "o que faz do luto um fenômeno normal, embora doloroso, é que, quando o trabalho do luto se conclui, o ego fica outra vez livre e desinibido. É por esse aspecto que o trabalho de luto pode ser comparado com o trabalho de lembrança. [...] pode-se sugerir que é enquanto trabalho de lembrança que o trabalho do luto se revela custosamente, mas também reciprocamente, libertador. O trabalho de luto é o custo do trabalho da lembrança, mas o trabalho da lembrança é o benefício do trabalho do luto." RICOUER, Paul. A memória, a história e o esquecimento. Campinas: Unicamp, 2007, p. 86. 
vias de terem respostas do Estado, configurando-se, assim, em uma "morte inconclusa"437 . "A categoria desaparecido representa uma tripla condição [de privação da morte]: a falta de um corpo $^{438}$, a falta de um momento de luto e a falta de uma sepultura. ${ }^{439}$ A recuperação do corpo $^{440}$ é colocada no plano das certezas, é a possibilidade de os familiares começarem uma nova etapa, na medida em que o desaparecimento se transformaria em morte, favorecendo, assim, a transformação de um suspenso na vida, a elaboração do luto e a homenagem ao ente querido. Por conseqüência à falta do corpo, há a falta do túmulo, lugar dedicado à lembrança dos familiares do ente querido, espaço destinado ao culto dessa pessoa. A ausência desse lugar faz com que seja necessário inventar outras estratégias para lembrar os desaparecidos, que podem ser públicas ou privadas ${ }^{441}$.

Nesse sentido, é retirada da vítima do desaparecimento forçado a existência na sociedade, na vida pública. Por sua vez, é arrancada, da família e amigos, uma pessoa de forma repentina, sem nenhuma explicação, impondo a eles uma situação de dor e eterna angústia por não saber se ela está viva, onde, em quais condições, se voltará a participar do convívio familiar, ampliando, dessa maneira, o conceito de vítima. Ninguém conta o que aconteceu, não se encontra o responsável pelo desaparecimento, e a situação mantém-se como se nada tivesse acontecido. "O paradeiro e a sorte da vítima são conhecidos por alguém. Alguém decidiu o que deveria ocorrer com a vítima; alguém decidiu manter em segredo. Alguém é

${ }^{437}$ CATELA, Ludmila da Silva. Situação limite e memória: reconstrução do mundo dos familiares de desaparecidos da Argentina. São Paulo: Hucitec/ Anpocs, 2001, pp. 141-2

${ }^{438}$ Idem, p. 150. "No ritual fúnebre o locus de culto é o corpo. Sobre ele se fala, sobre ele se chora, se colocam flores, se pronunciam discursos, de Sá o 'último adeus'. O corpo condensa e domestica a morte. Torna-a concreta, definitiva, presente, individual, identificada". Nesse sentido, os familiares dos desaparecidos não podem fazer seus rituais face à morte, como os velórios do corpo, a missa, o sepultamento. Além disso, os espaços que lhes sobram são as valas comuns (espaços que tradicionalmente serviam a enterrar indigentes, pessoas mortas por pestes na Idade Média, forma de apagar a identidade e não permitir a reconstituição dos laços familiares), já que não sabem da localização dos corpos de seus entes. P. 153-4.

${ }^{439}$ Idem, p. 150.

${ }^{440}$ Para Hebe de Bonafini, presidente da Associação das Mães da Praça de Maio, que é contrária à exumação dos corpos e sua respectiva identificação, junto com a palavra de ordem de "aparição com vida", identificar os corpos seria pôr fim ao problema dos desaparecidos, e com isso acabaria com a figura do revolucionário, com os sonhos e lutas a que destinaram suas vidas. Para ela, o exemplo dos desaparecidos serve às gerações futuras, em termos de ideologia. Idem, p. 158. Dessa forma, a mãe em questão fez de sua vida uma compreensão acerca da figura do desaparecido, que para ela deve ser lembrado como o revolucionário, como se a localização do corpo e a transformação do desaparecido em morto transformasse ou apaziguasse sua figura nas memórias enquanto agente político. Idem, p. 159: "Mas o ato do sepultamento não necessariamente destrói o ser social inserido em sua individualidade física. Este corpo sepultado, a quem agora foi devolvida a dignidade da identidade, ainda assim na percepção daqueles que recuperaram os restos, não foram apagadas as marcas de seu desaparecimento, seus familiares nunca deixaram de transportar essa marca histórica. [...] o sepultamento permitiu encerrar um ciclo e abrir outros marcados pelas palavras memória e o compromisso de não esquecer."

${ }^{441}$ Idem, p. 159. Estratégias como a manutenção de fotos e pertences do desaparecido, e sua inscrição nos espaços públicos, por meio de cartazes, manifestos são utilizadas pelos familiares no sentido de construírem signos de memória do desaparecido que ajudam a atenuar a morte. Idem, pp. 160-190. 
responsável." ${ }^{442}$. Seu futuro fica completamente à mercê de quem o captura. A pessoa desaparecida de repente deixa de existir, e todos os laços construídos ao decorrer da vida tornem-se apenas lembranças, sem que a verdade relativa ao seu destino venha à tona. Fica inviabilizado à família elaborar o luto, enterrar seu morto, restando sempre a esperança da pessoa desaparecida estar viva, e voltar a construir sua vida.

Dessa maneira, a figura do desaparecido surge nesse confrontamento com a morte; a pessoa havia sido presa, e, apesar dos anos sem notícias, não estava morta - mesmo que interiormente ou privadamente se soubesse dessa condição - estava desaparecida. Os familiares, em torno dessa situação de identificação, organizaram-se em grupos, e essa categorização de desaparecido foi fruto da ação coletiva que criou por sua vez uma identidade coletiva. A mulher do desaparecido não se considerava viúva, assim como seu filho não era órfão, demonstrando como as categorias de identidade usadas frente a uma situação de morte não davam conta de, simbolicamente, resolver a circunstância de desaparecimento. Esse processo de constituição do uso da palavra desaparecimento como novo sujeito, nova figura das relações sociais foi sendo lentamente construído, e, junto com ele, novas formas de os familiares se reconhecerem tanto em âmbito privado quanto público ${ }^{443}$.

Nesse sentido, há estreita relação entre identidade social e memória, evidenciando que esta última é fenômeno construído a partir das preocupações políticas do momento. A criação de identidade dos grupos de familiares de desaparecidos passa por três elementos essenciais, como anuncia Pollak:

A unidade física, ou seja, o sentimento de ter fronteiras físicas, no caso do corpo da pessoa, ou fronteiras de pertencimento ao grupo, no caso de um coletivo; a continuidade no tempo, no sentido físico e da palavra, mas também no sentido moral e psicológico; finalmente o sentimento de coerência, ou seja, de que os diferentes elementos que formam um indivíduo estão efetivamente unificados. Isto é tão importante que se há uma forte ruptura desse sentimento de unidade ou

\footnotetext{
${ }^{442}$ El paradero y la suerte de la víctima son conocidos por alguien. Alguien decidió lo que debía ocurrirle a la víctima; alguien decidió mantenerlo em secreto. Alguien es responsable. AMNESTY INTERNACIONAL. Desapariciones forzadas y homicídios políticos: La crise de los derechos humanos em los noventa. Madri: EDAI, 1994, p. 91.

${ }^{443}$ CATELA, Ludmila da Silva. Situação limite e memória: reconstrução do mundo dos familiares de desaparecidos da Argentina. São Paulo: Hucitec/ Anpocs, 2001, pp. 142-3. Nesse mesmo sentido, "Justamente sobre estas diferenças e hierarquias, tensões e soluções, silêncios e memórias, o simbolismo da filiação, que dotou de novas identidades a quem viveu a situação extrema da desaparição e da violência dos sequestros, concentra a força e originalidade para outorgar às experiências individuais o caráter de problema social, nacional. Os familiares de desaparecidos e os compañeros, mostram que, apesar da vivência de um clima de medo, de ruptura e de laços de confiança e de crenças institucionais, foram capazes de usar a solidariedade como um princípio ativo diante da situação-limite.” Idem, p. 374.
} 
continuidade, podemos observar fenômenos patológicos. Podemos, portanto, dizer que a memória é um elemento constituinte do sentimento de identidade, tanto individual como coletiva, na medida em que é também um componente muito importante do sentimento de continuidade e de coerência de uma pessoa ou de um grupo em sua reconstrução de si. ${ }^{44}$

Esses pontos têm reflexo direto na produção de memórias coletivas, por isso, além de constituir forma de reparação ouvir as vítimas, os familiares dos desaparecidos, torna-se essencial olhar para os acontecimentos passados, em uma tentativa de elaborar os fatos que ocorrem no presente. E uma das formas de se fazer essa ligação entre os tempos é por meio da vítima, dando a ela o reconhecimento de seu sofrimento, e usando sua experiência para publicizar as graves violações de direitos humanos e sua permanência. Nesse sentido, se a vítima permanece expulsa do seu lugar no mundo porque os espaços públicos não são capazes de dar-lhe o devido reconhecimento e acolhimento, ela se vê condenada a uma solidão moral. Se reparado o dano por meio de sua visibilidade no cenário público, sua identidade é construída, quando, por exemplo, os restos do desaparecido são localizados. Essa é uma das possibilidades de elaboração da grave violação, vindo à tona a materialidade dos fatos envoltos ao desaparecimento, como se consumasse tudo aquilo que os familiares disseram e reivindicaram.

Outro marco relevante nessa produção de memórias coletivas dos grupos de familiares, assim como das sociedades, é a tipificação do desaparecimento forçado de pessoas como crime contra a humanidade, pois, para além do papel de reparação e restabelecimento no sentido de possibilidade de reconciliação dos familiares da vítima e da própria sociedade com as instituições de poder, a situação do desaparecimento é afirmada por um ato de punição àquele que perpetuou tal crime, por meio do efeito do reconhecimento ${ }^{445}$, da consideração de seu

\footnotetext{
444 POLLAK, Michael. Memoria, olvido, silencio. La producción social de identidades frente a situaciones limite. La Plata: Ediciones Al Margen, 2006, p. 38. La unidad física, o sea, el sentimiento de tener fronteras físicas, en el caso del cuerpo de la persona, o fronteras de pertenencia al grupo, en el caso de um colectivo; la continuidad en el tiempo, en el sentido físico de la palabra, pero también en el sentido moral y psicológico; finalmente, el sentimiento de coherencia, o sea de que los diferentes elementos que forman um individuo están efectivamente unificados. Esto es tan importante que si hay uma fuerte ruptura de esse sentimiento de unidad o de continuidad, podemos observar fenômenos patológicos. Podemos, por lo tanto, decir que la memoria es un elementoconstituyente del sentimiento de identidad, tanto individual como colectiva, en la medida em que es también um componente muy importante del sentimiento de continuidad y de coherencia de uma persona o de um grupo em su reconstrucción de si.

${ }^{445}$ Nesse sentido, Perrone-Moisés aponta que "Ao estabelecer os fatos de maneira oficial, a sociedade diz à vítima que seu sofrimento não foi desconsiderado e que queremos, sim, conhecê-lo e também reconhecê-lo, como parte de nossa história comum." PERRONE-MOISÉS, Cláudia. O exercício do direito à verdade no Brasil pós-ditadura militar. In BENEVIDES, Maria Victoria de Mesquita, BERCOVICI, Gilberto, MELO, Claudineu de. Direitos Humanos, Democracia e República: Homenagem a Fábio Konder Comparato. São Paulo: Quartier Latin, 2009, pp. 275-6.
} 
sofrimento. Como conseqüência da punição aos responsáveis, a humanidade vai pautando em seus padrões mínimos de convivência aquilo que é intolerável enquanto modo de existir uns em relação aos outros.

Mostra-se, então, evidente a necessidade de punir os indivíduos responsáveis por perpetrar crimes dessa natureza. Todavia, há o questionamento, a partir da assertiva arendtiana de que homens não são capazes de perdoar o que não podem punir, nem punir o imperdoável, da impossibilidade de punição, ou seja, dos limites do direito, e quais seriam os casos em que a humanidade não pode punir. Para Arendt, o imperdoável refere-se aos crimes nazistas, um tipo de crime novo - o massacre administrativo, o que ela chama, com base em Kant, de "mal radical". A inadequação das penas existentes, dado o ineditismo dos crimes cometidos e de sua imensa crueldade, parece constituir obstáculo para a punição ${ }^{446}$. E é nesse sentido que se observa a insuficiência da punição a esses criminosos, sendo necessário atentar ao que as vítimas querem, já que representam a humanidade tanto quando o crime atua em seu corpo, como quando expressam os modos como seriam reparadas dos crimes cometidos, sempre no sentido de convocarem a sociedade em geral para elaborarem suas memórias, para compartilharem seu sofrimento e serem reconhecidas a partir dele.

É nesse marco, então, que algumas vítimas demandam reparação, mas de crimes que são irreparáveis; demandar justiça torna-se o senso de suas vidas. Esta justiça é um modo de reconhecer e de qualificar a vítima à categoria de humanidade. Quando testemunham os fatos ocorridos retomam a palavra e são ouvidas, regressam ao mundo político. Trata-se, desse modo, da possibilidade de narrativa do vivido em situações-limite ${ }^{447}$, que, apesar dos anos transcorridos, ainda mobilizam os familiares a buscarem os restos de seus desaparecidos, ou no mínimo saberem efetivamente o ocorrido.

O valor da memória, como fórmula de justiça, em detrimento da aplicação de um processo judicial, também foi apontada por Garapon, ao afirmar que a memória havia se tornado o imperativo que exonerava a tarefa ingrata de se fazer justiça com instrumentos prosaicos, como as regras e os princípios processuais, pois as ficções jurídicas tornaram-se escandalosas quando o sofrimento humano encontra-se em

\footnotetext{
${ }^{446}$ PERRONE-MOISÉS, Cláudia. O perdão e os crimes contra a humanidade - um diálogo entre Hannah Arendt e Jacques Derrida. In: CORREIA, Adriano (org.). Hannan Arendt e a Condição Humana. Salvador: Quarteto, 2006, p. 212.

${ }^{447}$ Para Ludmila Catela (Situação limite e memória: reconstrução do mundo dos familiares de desaparecidos da Argentina. São Paulo: Hucitec/ Anpocs, 2001), situação-limite é aquela que aparece para desmembrar toda a ordem do mundo cotidiano, cultural, político e religioso em que as pessoas estão imersas, onde foram socializadas, onde se aprendeu a se relacionarem, a viver.
} 
jogo, de tal forma que as exigências processuais assemelham-se a formalidades inúteis e ultrajantes. $^{448}$

Nesse sentido, Perrone-Moisés propõe encontrar um lugar entre o perdão e a punição. Como sugestão de modelo, as comissões de verdade e reconciliação podem ser entendidas como espaços onde as vítimas, seus familiares e a sociedade têm a possibilidade de se reconciliar com o passado, compreendendo o que se passou, fazendo com que o indivíduo se sinta de novo em casa no mundo.

\begin{abstract}
No que se refere à descaracterização do perdão, tendo em vista a pergunta - quem deve perdoar? - Derrida menciona o exemplo daquela mulher da África do Sul cujo marido tinha sido preso e torturado, e que na Comissão de Verdade e Reconciliação disse o seguinte: uma comissão ou um governo não pode perdoar. Só eu, eventualmente, poderia fazer isso. Mas não estou pronta para perdoar. Para Derrida, essa afirmação relembra o fato de que o corpo anônimo do Estado ou de uma instituição pública não pode perdoar. O Estado pode julgar, mas o perdão não tem nada a ver com o julgamento, nem mesmo com o espaço público ou político. Mesmo se fosse "justo", o perdão não teria nada a ver com a justiça judiciária, com o direito. $^{449}$
\end{abstract}

Nessa direção, para evitar a falta de significações do passado na reconstrução de democracias recentes, Arendt propõe o recurso à modalidade do pensamento que permite o desvelamento das experiências vividas, ou seja, a compreensão. O sofrimento pelo qual se passa somente pode ser absorvido e transformado em experiência se for possível conceder-lhe publicidade, com a possibilidade das vítimas e testemunhas serem ouvidas e vistas pelos outros. A compreensão é uma atividade interminável, a maneira especificamente humana de estar $\operatorname{vivo}^{450}$.

Geralmente se pensa que a memória, por sua característica fragmentária, deve estar vinculada à história, que integra objetivamente o maior número de documentos, em detrimento da subjetividade de testemunhos e lembranças. A superioridade da história se manifesta na sociedade em razão do caráter evolucionista ou historicista, que situa os fenômenos observados em uma evolução que vai da tradição à modernidade. É relegada à memória a classificação de percepção individual, ou de um grupo particular, que visa à afirmação de sua

\footnotetext{
448 BASTOS, Lucia Elena Arantes Ferreira. As leis de anistia face ao direito internacional. O caso brasileiro. Tese de doutorado apresentada no Departamento de Direito Internacional da Faculdade de Direito, USP, 2007, p. 65.

${ }^{449}$ PERRONE-MOISÉS, PERRONE-MOISÉS, Cláudia. O perdão e os crimes contra a humanidade - um diálogo entre Hannah Arendt e Jacques Derrida. In: CORREIA, Adriano (org.). Hannan Arendt e a Condição Humana. Salvador: Quarteto, 2006, p. 214.

450 ARENDT, Hannah. A dignidade da política. Rio de Janeiro: Relume-Dumará, 1993, p. 39.
} 
identidade. ${ }^{451}$ Contudo, elas não são opostas ou se anulam, mas são confluentes, e informamse. O equívoco é imaginar que a demanda de alguns grupos acerca de suas memórias é ilegítimo, e considerar que a luta pela memória dos desaparecidos e dos grupos de familiares não diz respeito à humanidade, e deveria ficar adstrita ao âmbito individual.

É neste campo que se situa a importância de inserir no campo de disputas de memórias ${ }^{452}$ as memórias das vítimas, que relacionam a questão da memória com um passado ainda em conflito no presente. Apesar de todas as discussões públicas em torno da justiça e da responsabilidade, parece insuficiente se as memórias das vítimas não aparecerem no cenário público, para abordar os traumas vividos. Seria então necessário a constituição de um espaço público onde elas possam vir à tona, e serem elaboradas, como alternativa de reparação e reconciliação com o passado. Isso porque a humanidade não pode admitir que pessoas tenham seus direitos eliminados, sua vida disposta com crueza e crueldade, como em casos de desaparecimento forçado. Do mesmo modo, os familiares não podem ter seu ente querido retirado tão violentamente de seu convívio. Além de todo sofrimento e conseqüências gerados por esse fenômeno no âmbito privado do desaparecido, que já justificaria toda atenção jurídica e política, há as implicações públicas e coletivas, pois o significado de retirar uma pessoa de sua vida, e submetê-la à vontade injusta de outras pessoas ou instituições, desconsiderando toda construção histórico-jurídica, é, entre diversas coisas, uma afronta ao patamar mínimo de valores que a humanidade decidiu respeitar.

\subsection{Memória e direitos humanos}

Cumpre abordar neste momento a relação das memórias com a linguagem e princípios dos direitos humanos. Tratando-se das memórias individuais e sua relação com os direitos humanos, em caso de desaparecimento forçado de pessoas, aponta-se que os familiares têm não só o direito à verdade, no sentido de saberem os fatos ocorridos acerca das circunstâncias do desaparecimento, mas têm o direito de recobrarem os restos mortais, para enterrarem seu

${ }^{451}$ TOURAINE, Alain. Memoria, historia, futuro. In ACADEMIA UNIVERSAL DE LAS CULTURAS. Por qué recordar? Buenos Aires: Granica, 2006, pp. 199-205.

${ }^{452}$ Pollak analisa: [...] la memoria y la identidad son valores disputados en conflitos sociales e intergrupales, y particularmente, en conflitos que oponen grupos políticos diversos. POLLAK, Michael. Memoria, olvido, silencio. La producción social de identidades frente a situaciones limite. La Plata: Ediciones Al Margen, 2006, p. 38-9. 
morto, elaborarem seu luto e encerrarem um suspenso em suas vidas, e essa compreensão insere-se na perspectiva dos valores de direitos humanos, pois está alinhado com o respeito universal que todas as culturas têm de realizar atos fúnebres para homenagear seus mortos. Ademais, para Cançado Trindade há um legado espiritual dos mortos captado pela consciência humana, podendo-se afirmar que

No campo da ciência do direito, não vejo como deixar de afirmar a existência de uma consciência jurídica universal (correspondente a opinio juris comunis), que constitui [...] a fonte material por excelência (além das fontes formais) de todo o direito das gentes, responsável pelos avances do gênero humano não só no plano jurídico, mas também no espiritual. O que nos sobrevive é tão somente a criação de nosso espírito, com o propósito de elevar a condição humana. É assim como concebo o legado dos mortos, de uma perspectiva dos direitos humanos. ${ }^{453}$

Para o mesmo juiz, a dimensão espiritual da consciência jurídica universal é expressa em diversos instrumentos internacionais de direitos humanos, na medida em que invoca reiteradamente os princípios de humanidade e de consciência pública ${ }^{454}$. Nesse mesmo plano situa-se a solidariedade humana ${ }^{455}$, que pauta as relações humanas no que concerne ao respeito ao modo como os vivos reverenciam seus mortos. Desse modo, a possibilidade de cada familiar elaborar seu luto mediante seus ritos fúnebres e sepultamento, enquadra-se nessa perspectiva da solidariedade humana, na medida em que tem o potencial de encerrar um ciclo da vida humana para os vivos, considerando o quanto a morte afeta aqueles que permanecem

${ }^{453}$ Caso Bámaca Velasquéz vs. Guatemala, sentença de mérito, voto arrazoado Cançado Trindade, p. 5, para. 16 : De igual modo, en el campo de la ciencia del derecho, no veo cómo dejar de afirmar la existencia de una conciencia jurídica universal (correspondiente a la opinio juris comunis), que constituye, en mi entender, la fuente material por excelencia (más allá de las fuentes formales) de todo el derecho de gentes, responsable por los avances del género humano no sólo en el plano jurídico sino también en el espiritual. Lo que nos sobrevive es tan sólo la creación de nuestro espíritu, con el propósito de elevar la condición humana. Es así como concibo el legado de los muertos, desde una perspectiva de los derechos humanos.

454 Idem, pp. 5 e 8, paras. 19 e 28: 28. Los derechos humanos universales encuentran respaldo en la espiritualidad de todas las culturas y religiones, están arraigados en el propio espíritu humano; como tales, no son la expresión de una determinada cultura (occidental o cualquier otra), sino de la propia conciencia jurídica universal. Todos los avances mencionados, debidos a esta conciencia jurídica universal, se han dado en medio a la diversidad cultural. Al contrario de lo que pregonan los voceros del llamado - y distorsionado - "relativismo cultural", las manifestaciones culturales (al menos las que se conforman con los estándares universalmente aceptados de tratamiento del ser humano y de respeto a sus muertos) no constituyen obstáculos a la prevalencia de los derechos humanos, sino todo al revés: el substratum cultural de las normas de protección del ser humano en mucho contribuye para asegurar su eficacia. Dichas manifestaciones culturales - como la del respeto a los muertos en las personas de los vivos, titulares de derechos y de deberes - son como piedras sobrepuestas con las cuales se erige la gran pirámide de la universalidad de los derechos humanos.

455 Caso Bámaca Velasquéz vs. Guatemala, sentença de reparações e custas, voto arrazoado, Cançado Trindade, pp. 6-7 e 9, paras. 16 e 23. 16. Años después, en su libro L'État, le Droit objectif et la loi positive (1901), Léon Duguit retomó el "solidarismo", a partir de la advertencia de que los seres humanos sólo pueden vivir en sociedad, cuyo hecho fundamental es la "solidaridad social": así, el daño causado a una persona afecta a todo el tejido social. El ser humano sufre y muere solo, pero la suma de los sufrimientos humanos es menor cuando cada uno vive en relación con los demás; la precariedad de la condición humana fomenta la solidaridad, la cual torna el sufrimiento menos insoportable y une los miembros del género humano, toda la humanidad. La solidaridad se nutre precisamente del deseo de disminuir el sufrimiento humano. 
em vida. Nesse sentido, a impossibilidade de se elaborar o luto constitui afronta aos valores e princípios de direitos humanos, pois uma das manifestações dessa condição humana é a relação que existem entre os vivos e mortos, de forma que o respeito aos mortos situa-se no respeito aos vivos de compartilharem da existência conjuntamente, considerando que o ciclo da vida e da morte é objeto de experiência de toda a humanidade, a despeito do modo como cada cultura reage diante desse fato eminentemente humano.

Nessa perspectiva, para Bobbio, há três formas de fundar os valores de direitos humanos, deduzindo-os de um objeto constante, da natureza humana; considerando-os como verdades evidentes em si mesmas; e que em um dado período histórico eles são aceitos e apoiados no consenso, "o que significa que um valor é tanto mais fundado quanto mais é aceito" ${ }^{456}$. Desta feita, já é provado que as duas primeiras maneiras não têm base racional e não se confirmaram - o autor aponta como o direito natural dos jusnaturalistas não sustentou a não violação de direitos humanos, como também demonstrou Hannah Arendt ao afirmar que não se viu nada de sagrado em ser unicamente humano; assim como a evidência das verdades para um momento histórico pode ser diferente em outro, a exemplo da sacralidade da propriedade privada na Declaração Francesa que, hoje, não encontra mais amparo em termos de valores de direitos humanos. Resta então, a última forma de se consagrar valores, considerando que sua eleição a esta categoria depende exclusivamente daquilo que os homens decidiram. Assim, a DUDH é o maior sistema de valores comuns universal na história da humanidade, porque baseada no consenso acerca de sua validade. "[...] toda a humanidade partilha alguns valores comuns; [...] universal significa não algo dado objetivamente, mas algo subjetivamente acolhido pelo universo dos homens" ${ }^{, 457}$.

A compreensão de que há um respeito pela dignidade dos vivos em relação aos seus mortos situa-se nesse campo de valores universais que a humanidade elegeu. E nessa mesma direção, o direito à verdade e com ele o acesso aos restos mortais do desaparecido, constituindo possibilidade de elaborar o luto pela perda de um ente querido, apresenta chance de os familiares manterem o laço que vincula os mortos e vivos. Esses elementos garantem um ponto de partida para que cada pessoa afetada pelos acontecimentos possa construir suas memórias, lembrar de seu ente querido de maneira apaziguada, compreendendo que um ciclo da vida foi encerrado, e com isso seguir adiante a partir das lembranças e com as memórias da

${ }^{456}$ BOBBIO, Norberto. A Era dos Direitos. Rio de Janeiro: Campus, 2004, p. 47.

${ }^{457}$ Idem, p. 48. 
relação que se teve com ele, com saudades, como é natural quando da morte de uma pessoa do ciclo relacional. Pode-se então amparar tal consideração no que Gagnebin considerou a partir da leitura de Nietzsche, Freud, Adorno e Ricouer:

Em oposição a essas figuras melancólicas e narcísicas da memória [os autores] defendem um lembrar ativo: um trabalho de elaboração e de luto em relação ao passado, realizado por meio de um esforço de compreensão e esclarecimento - do passado e, também, do presente. Um trabalho que, certamente, lembra dos mortos, por piedade e fidelidade, mas também por amor e atenção aos vivos. ${ }^{458}$

Os direitos humanos universais amparam as pessoas frente à vulnerabilidade de sua condição. Em um contexto de se imprimir em cena pública as demandas desses grupos mais vulneráveis, a normativa e as ações políticas de direitos humanos localizam nesses grupos seu marco de proteção e atuação. A condição das vítimas indiretas do desaparecido encontra-se nesse lugar, em razão de seu sofrimento e constantes violações de direitos humanos consagrados, como visto nos capítulos anteriores. Nesse sentido, a linguagem dos direitos humanos possibilita a construção de memórias coletivas dos grupos quem têm menos visibilidade no cenário político, como por vezes é o caso dos grupos de familiares de vítimas de desaparecimento. Nessa medida, os direitos humanos figurariam como um discurso cuja significação política encontra uma posição estratégica e variável nas relações sociais, e habilita colocar no centro da juridicidade as vítimas que foram eleitas e se constituem como tal. Assim, em sua possibilidade de dar visibilidade àquelas subjetividades excluídas a partir dos seus contextos de dominação, atualizariam a potência de enfrentamento contra hegemônico e a redução da autoridade. $^{459}$

Dessa forma, considerando que um contexto político-jurídico orientado pelo respeito aos direitos humanos tem por fim fazer frente a uma situação hegemônica, no sentido de proteger aqueles que têm menos visibilidade e acesso ao debate público e político, e menos condições de levar suas reivindicações, necessidades e questões a uma arena política, e, por isso a normativa de direitos humanos operam no sentido de favorecer essa tomada da palavra, podese considerar que também na batalha de memórias coletivas, em que os grupos visam a colocar em cena suas questões do passado que lhes interessam no presente, a proteção jurídica

\footnotetext{
${ }^{458}$ GAGNEBIN, Jeanne-Marie. O que significa elaborar o passado? In Lembrar escrever esquecer. São Paulo: Editora 34, 2006, p. 105.

459 AZZALI, Javier Carlos. Memoria colectiva y discurso jurídico. In Revista Crítica Jurídica, n. 20, jan-jul 2002, p. 31.
} 
dos direitos humanos possibilita a inclusão das questões dos familiares dos desaparecidos na pauta pública.

Para além do âmbito privado - aqui constituído pelos grupos de familiares que portam a preservação e constituição de suas memórias em cena pública - é necessário tratar do possível impacto das memórias das vítimas no modus operandi da sociedade como um todo. É relevante para toda a coletividade saber dos fatos relacionados a graves violações de direitos humanos, as estratégias empreendidas no cometimento de tais violações, seus fundamentos e características, no sentido de alertar a todos para uma não-repetição. Saber pelo que passaram as vítimas do passado também é atividade importante, não só devido à solidariedade humana, mas sobretudo porque é maneira de se reconhecer em situação pela qual não se quer passar no presente, considerando o marco valorativo de uma existência humana alinhado aos princípios e valores de direitos humanos. Desse modo, lembrar do passado não se configura tão somente em rememorar para as atrocidades não caírem no esquecimento e os sujeitos se manterem em seus papéis de vítima ou algoz, mas para transcender e fazer de tudo para que algo semelhante não aconteça, para que não se repita ${ }^{460}$.

Catela narra um episódio ocorrido em 1999 na Argentina, que também diz respeito à realidade de seus países vizinhos da América Latina que passaram por ditaduras recentes, e tiveram como marca a prática de crimes contra a humanidade:

[...] cinco jovens da província de Buenos Aires foram presos pela polícia local como suspeitos do roubo da arma de um policial e submetidos a uma das práticas de torturas mais utilizadas durante a ditadura - o "submarino". Sergio, de 26 anos, estudante de direito, refere-se a essa noite com palavras muito claras: "puxaram-me os braços para trás, e três me agarraram e me colocaram um saco na cabeça. No desespero, pude tirá-lo e me safei. Voltaram a me agarrar e outra vez me colocaram no saco. Assim várias vezes. Terminei chorando, ajoelhado no chão. Nesse momento me lembrei da década de 70 e dos desaparecidos. Pensei que iam me matar. ${ }^{461}$

O debate acerca dessa temática, remontando o passado que ainda é presente, coloca em xeque o modo como as memórias são construídas e podem constituir uma forma de reparação à violação e ao crime. Além disso, oferece elementos para compreender o tipo de bases em que se formam as atuais democracias na América Latina. Assim, essa percepção de uma

\footnotetext{
${ }^{460}$ GAGNEBIN, Jeanne-Marie. O que significa elaborar o passado? In Lembrar escrever esquecer. São Paulo: Editora 34, 2006, p. 100.

${ }^{461}$ CATELA, Ludmila da Silva. Situação limite e memória: reconstrução do mundo dos familiares de desaparecidos da Argentina. São Paulo: Hucitec/ Anpocs, 2001, pp. 367-8.
} 
continuidade de estruturas de um regime ditatorial não é clara no jogo político, haja vista a permanência de uma estrutura policial, por exemplo, que mantém em seus métodos de ação a tortura ou a execução extrajudicial. Há mudança da categoria de vítima que agora se apresenta de forma difusa, e não mais como opositora ao regime. Contudo, uma lógica de ação que tem raízes em uma política ditatorial demonstra que no jogo de prevalência de memórias parece haver uma sobreposição daquela que pretendia manter a ordem - usando meios abomináveis em detrimento das memórias das vítimas, embora essa aparição no público e confluência entre elas não seja tão simples e linear assim. A razão, no entanto, de se buscar esquecer o passado porque se nega os fatos acontecidos, ou se finge que nada ocorreu, pode causar prejuízos a um novo sistema político que se pretenda ser democrático e baseado nos valores de direitos humanos, isso porque ignorar essas memórias sustenta aquilo que não se quer ver nem ter acesso, favorecendo que a manutenção de métodos utilizados naquele momento também fique em um campo obscuro e oculto na cena pública.

Se por um lado a orientação dos direitos humanos favorece a tomada da palavra por parte de alguns grupos, e com isso há a chance de suas memórias terem espaço nas memórias das coletividades no sentido de reconhecimento, por outro elas têm a capacidade de informar o debate público e assim participarem da construção de direitos humanos, que dizem respeito a todos. Então, as memórias dos familiares de desaparecidos referem-se à coletividade e humanidade, em uma perspectiva de preservação e escuta, mas também porque trazem à tona graves violações de direitos humanos, e isso impacta a formação de outras memórias e tem reflexo direto na possibilidade de transformar o presente. Por exemplo, a atuação dos familiares foi essencial para que a ordem jurídica internacional passasse a considerar o desaparecimento como grave violação de direitos humanos e crime contra a humanidade, assim como o direito à verdade reconhecido pela ONU advém da relação com a questão dos desaparecidos. Esses espaços de luta e memórias constituídos a princípio pelos familiares apontam significativas conquistas no campo dos direitos humanos, no que concerne à proteção de vítimas de violências.

Cada cultura nacional, contudo, dentro daqueles valores universais dos direitos humanos, associa quais são as memórias, grupos ou direitos que terão mais visibilidade no cenário público. Trata-se das diretrizes políticas a que cada país, em determinado momento, vai seguir, de modo que elas estão atreladas às memórias coletivas e às disputas dessas memórias. Assim, cada Estado com sua cultura, a partir de um patamar mínimo de valores, vai 
delineando a associação dos direitos humanos com as memórias coletivas. Nessa perspectiva, reflete Catela:

[...] a noção de direitos humanos e memória nos coloca a clássica pergunta a respeito aos seus usos em sentido literal ou exemplar, como dizia Todorov. A questão é se os grupos sociais, o Estado, opta por um uso literal recuperando todos seus detalhes, [...], como um evento que não pode ser comparado com outros, ou se opta por um uso exemplar no sentido de pensar nisso como um modelo que permite compreender principalmente situações novas, do presente, sacrificando a singularidade do sucesso em si mesmo. Aqui novamente se coloca a necessidade de colocar a questão acerca do quando e para quê usamos o discurso da memória e dos direitos humanos. [...] Enfim, a pergunta é então se a memória se usa em sua literalidade, em sua sacralidade do passado ou deve servir para dar espaços a leituras exemplares, colocando dessa maneira uma pluralidade de pontos de vistas, com os quais podemos não estar de acordo, mas que podem permitir pensar mais completamente o presente. $^{462}$

Para Perrone-Moisés, há relação direta entre os fatos acontecidos no passado e sua permanência no presente, caso não seja aberto espaço para a elaboração e compreensão do ocorrido:

O exercício da memória não deve ser apenas mecânico ou memorialista, deve também, e sobretudo, ser inventivo. Repensar a história, reconstruir as memórias do passado, é também contribuir para pensar outros futuros possíveis. Num país onde não se pune a tortura do passado, é natural que a mesma permaneça como um "habitus", como diria Norbert Elias, no seio de uma sociedade inerte e impotente para se renovar. ${ }^{463}$

A esse debate soma-se aquilo que Bobbio declarou acerca da interdependência dos direitos humanos, da democracia e da paz, que são

três momentos necessários do mesmo movimento histórico: sem direitos do homem reconhecidos e efetivamente protegidos não existe democracia, sem democracia não existem as condições mínimas para a solução pacífica dos conflitos que surgem entre os indivíduos, entre grupos e entre as grandes coletividades tradicionalmente

462 CATELA, Ludmila. Derechos humanos y memoria. Historia y dilemas de uma relación particular. $8^{\circ}$. Congresso Argentino de Antropologia Social, 19-22 de setembro de 2006, p. 14. [...] la noción de derechos humanos y memoria nos platea la ya clasica pregunta respecto a sus usos em sentido "literal" o "ejemplar", al decir de Todorov. La cuestión es si los grupos sociales, el Estado, opta por un uso "literal" recuperando todos sus detalles, [...] como un evento que no puede ser comparado con otros, o se opta por un uso "ejemplar" en el sentido de pensar en el como un modelo que permite comprender principalmente situaciones nuevas, del presente, sacrificando la singularidad del suceso en si mismo. Aquí nuevamente se plantea la necessidad de preguntarnos cuándo y para qué usamos el discurso de la memoria y los derechos humanos. [...] En fin, la pregunta entonces es si la memoria se usa em su literalidad, en su sacralidad del pasado o debe servir para dar espacio a lecturas "ejemplares", colocando de esta manera una pluralidad de puntos de vistas, con los podemos no estar de acuerdo, pero que pueden permitir pensar más complejamente el presente.

463 PERRONE-MOISÉS, Cláudia. O exercício do direito à verdade no Brasil pós-ditadura militar. In BENEVIDES, Maria Victoria de Mesquita, BERCOVICI, Gilberto, MELO, Claudineu de. Direitos Humanos, Democracia e República: Homenagem a Fábio Konder Comparato. São Paulo: Quartier Latin, 2009, p. 276. 
indóceis e tendencialmente autocráticas que são os Estados, apesar de serem democráticas com os próprios cidadãos ${ }^{464}$.

Os medos e inseguranças da coletividade se formam a partir de impunidade e incerteza. $\mathrm{O}$ direito à verdade que tem a sociedade deve ser estabelecido, para que as memórias sejam construídas a partir do conhecimento da totalidade dos fatos, compreendendo que a democracia exige o poder visível, pois pertence "à natureza da democracia o fato de que nada pode permanecer confinado no espaço do mistério" 465 . Assim, conforme analisa Bobbio, todos os atos de governo devem ser públicos, e esse fator diferencia o Estado constitucional do Estado absoluto, que assinala "o nascimento ou renascimento do poder público em público" ${ }^{\text {466 }}$. Dessa maneira, a sociedade pode ter a capacidade de decidir e escolher os caminhos que pretende seguir a partir daquilo que tem conhecimento, e para isso precisa ter acesso a todas as operações dos governantes.

Nessa perspectiva, para que as escolhas do presente possam estar orientadas também pelos fatos aprendidos do passado, "deve pois haver alguém que chame a si a tarefa de representar a memória coletiva e, portanto, de não omitir nada que nos ajude a entender. Nossa história recente foi atravessada por inúmeros fatos misteriosos para que não deva refletir sobre a fragilidade e sobre a vulnerabilidade das nossas instituições democráticas" ${ }^{467}$. O desafio, então, é no sentido de provocar um desocultamento ${ }^{468}$ dos fatos ocorridos durante as ditaduras da América Latina, visando não só a que a democracia tenha como um dos princípios basilares o poder visível, mas que tenha condições de aprender com os fatos do passado e com isso não cometer as mesmas violações de direitos humanos.

\footnotetext{
${ }^{464}$ BOBBIO, Norberto. A Era dos Direitos. Rio de Janeiro: Campus, 2004, p. 223.

${ }^{465}$ BOBBIO, Norberto. A democracia e o poder invisível. In: O futuro da democracia. São Paulo: Paz e terra, 2000, $11^{\text {a }}$. ed., p. 98.

${ }^{466}$ Idem, p. 101.

${ }^{467}$ Idem, p. 119.

${ }^{468}$ Idem, p. 116. Desocultamento como a "denúncia de ações realizadas sem caráter público que, uma vez tornadas públicas, suscitam escândalos".
} 


\section{CONCluSÃo}

Esta dissertação tratou o tema do desaparecimento forçado de pessoas como fenômeno emergente em âmbito global, a partir da análise da formação do direito internacional dos direitos humanos, em concerto com o direito internacional humanitário e direito internacional penal, e dos seus atuais desafios. Por meio da descrição histórica do desaparecimento sob as vertentes do desenvolvimento da normativa internacional e da atuação das organizações internacionais, Estados, organizações não-governamentais e familiares, procurou-se compreender sentido e contextos desse crime contra a humanidade. Ademais, em razão de tal evento ter relação fundamental com o direito à verdade, o trabalho apresentou a análise dos casos de desaparecimento forçado de pessoas julgados pela Corte Interamericana de Direitos Humanos, com o fim de verificar como esse tribunal vem tratando a matéria, e, por conseguinte, como vem formando seu entendimento acerca do exercício da verdade. Por fim, visou a fazer uma aproximação entre memória e direitos humanos, com o objetivo de identificar elementos dessa temática, já que aparece recorrentemente associada à questão do desaparecimento forçado de pessoas.

A complexidade do desaparecimento forçado de pessoas tanto em relação a sua conceituação jurídica, quanto ao seu tratamento nas esferas política, jurídica, social, pública e privada, gera uma necessidade de aproximação de todos os atores internacionais no sentido de identificarem as melhores maneiras de se lidar com essa situação que, não obstante ter se originado no contexto das ditaduras da América Latina, é hoje prática comum e expressiva nos países do Oriente Médio e África ${ }^{469}$. Nesse esteio, o desaparecimento forçado de pessoas constitui uma das mais graves violações de direitos humanos, e por essa razão é classificado como crime contra a humanidade, como visto ao longo desta dissertação. Em razão de seu caráter multifacetado, esse fenômeno priva de direitos não só a vítima do desaparecimento, mas seus familiares, a sociedade e a humanidade como um todo, na medida em que, para além das violências cometidas contra o desparecido e seus familiares, retira a pessoa da convivência e existência no mundo ${ }^{470}$.

\footnotetext{
${ }^{469}$ A/HRC/10/9, p. 83.

${ }^{470}$ ARENDT, Hannah. O que é política? Rio de Janeiro: Bertrand Brasil, 1999.
} 
Em face dessa gravidade, o direito internacional vem formando uma base normativa para proteção das pessoas contra o desaparecimento, informado pelas ações dos agentes internacionais comprometidos com a erradicação de tal prática do âmbito das relações humanas. Esse movimento de normativização do desaparecimento teve início com a Declaração de 1992 no seio da ONU, paralelamente com a Convenção da OEA de 1994, a inclusão no Estatuto de Roma de 1998 da violação como crime contra a humanidade, e finalmente com a Convenção de 2006 da ONU. Apesar de essa consolidação jurídica ter começado na década de 1990, desde 1970 verifica-se interesse da ONU e OEA em elaborar um espectro protetivo às pessoas contra o desaparecimento forçado, como visto nas recomendações dessas duas organizações aos Estados onde houve prática de desaparecimento. É válido ressaltar que os entendimentos dessas organizações acerca do significado do fenômeno, bem como os aspectos correlatos a ele, foram sendo desenvolvidos ao longo desse período em análise, muito em virtude das demandas e orientações dos familiares.

Dessa maneira, durante a década de 1970, os atores internacionais voltaram sua atenção para a conceituação do desaparecimento, e a identificação da conjuntura em que ele acontecia. $\mathrm{Na}$ década seguinte, com a criação do Grupo de Trabalho sobre Desaparecimento Forçado ou Involuntário de Pessoas, iniciou-se uma pressão internacional para que os Estados passassem a localizar as vítimas de desaparecimento, bem como a responsabilizar os perpetradores dessa prática, surgindo a necessidade de combate à impunidade como forma de prevenir esse tipo de violação. A questão da impunidade passa a ser debatida nesse momento em virtude da abertura dos regimes ditatoriais para a democracia em boa parte dos países da América Latina onde ocorreram desaparecimentos, e, um dos aspectos dessa transição que interferiu sobremaneira na persecução penal daqueles que cometeram desaparecimento foi a promulgação das leis de anistia. Na década de 1990, em que valas comuns passaram a ser encontradas, estabelece-se nas recomendações dos órgãos internacionais o dever do Estado de identificar os restos mortais e devolvê-los aos familiares. $\mathrm{O}$ que se mostra, nessa perspectiva, é que os instrumentos de proteção contra o desaparecimento, bem como as recomendações da ONU e OEA, foram informados pelas circunstâncias que se deparavam os familiares das vítimas de desaparecimento.

Nesse sentido, o desaparecimento forçado de pessoas evidencia claramente o apontamento de Delmas-Marty "é para o lado das vítimas que é preciso estar voltado para procurar valores 
comuns, apesar das civilizações diferentes, talvez até opostas". ${ }^{471}$ Isso porque para compreender a gravidade do tema em questão, é essencial que o olhar esteja na direção do sofrimento das vítimas, de modo que todas as sociedades possam se reconhecer nesse lugar e se solidarizar com essa situação - caracterizando-se, assim, o "fundo comum de valores que chamamos de Humanidade."472 Dessa maneira, observou-se que instrumentos de proteção, bem como as ações das organizações, levam em consideração a condição das vítimas.

No que diz respeito à formação da base jurídica internacional relativa ao desaparecimento forçado de pessoas, verificou-se o alto grau de interdependência entre o direito internacional dos direitos humanos, direito internacional humanitário e direito internacional penal, evidenciado pelo histórico de suas formações. É certo que os três ramos do direito internacional têm por fim máximo a proteção da dignidade da pessoa humana, e, em caso de desaparecimento, é nítida a afronta aos valores mínimos de direitos humanos. Assim, o enredamento desses três ramos no sentido de responsabilização dos Estados e dos indivíduos, no que concerne à obrigação de prevenir, proteger e reparar em caso de desaparecimentos forçados, mostrou-se de forma clara. Adicionalmente, vê-se como o direito internacional vem pressionando os Estados a incorporarem suas determinações pela ratificação dos tratados e adequação de suas legislações internas, como manifesto especialmente nas revogações das leis de anistia de alguns países da América Latina, julgamento dos responsáveis pela prática de desaparecimento na época das ditaduras, tipificação do desaparecimento como crime nos códigos penais.

Relativamente aos casos de desaparecimento forçado de pessoas julgados pela Corte Interamericana de Direitos Humanos da OEA, diversos aspectos foram observados, contudo, o foco de análise restringiu-se ao modo como esse tribunal trata do direito à verdade. Em termos de violações de direitos humanos consagrados na Convenção Americana, o alcance acerca do conceito de vítima vai se ampliando no entendimento da Corte a partir do caso Blake vs. Guatemala, quando pela primeira vez manifesta a violação aos direitos dos familiares pela falta de informações e dificuldade de terem acesso à justiça para saberem das circunstâncias relativas à situação do desaparecimento, configurando-se forma de tortura psicológica. Dessa maneira, a jurisprudência da Corte acerca da condenação dos Estados por

${ }^{471}$ DELMAS-MARTY, Mireille. Os crimes internacionais podem contribuir para o debate entre universalismo e relativismo de valores? In: CASSESSE, Antonio e DELMAS-MARTY, Mireille (orgs.) Crimes Internacionais e Jurisdições Internacionais. São Paulo: Manole, 2004, p. 69.

${ }^{472}$ Idem, p. 71. 
violarem direitos humanos nos casos de desaparecimento forçado mostrou-se incisiva e implacável, expressando sempre a necessidade de se prevenir e tomar todas as medidas para que esse tipo de crime não aconteça mais.

No que concerne ao direito à verdade, reconhecido pela ONU e pela Comissão de Direitos Humanos da OEA como direito autônomo, a Corte reconhece como essencial o conhecimento da verdade nos casos de desaparecimento, mas entende que o direito à verdade está subsumido aos direitos de acesso à justiça e garantias processuais. No mais, aponta que os familiares têm o direito de saberem das circunstâncias como forma de reparação pelo desaparecimento. Desse modo, recorre-se à distinção de Todorov quando sugere que a verdade tem ao menos dois sentidos, aquela factual, relacionada à "coleta de informações e respondendo questões: quem, quando, onde, quanto, como... E, [...] uma verdade de interpretação, que se refere ao próprio sentido dos acontecimentos, seu lugar na história humana, seu alcance tanto para os contemporâneos quanto para as gerações seguintes" ${ }^{473}$, pois sua análise oferece elementos para refletir acerca da tênue linha entre o direito à verdade, que consiste na obrigação do Estado de oferecer a quem tiver interesse todas as informações das quais dispõe acerca da grave violação de direitos humanos, e a construção de memórias individuais e coletivas, a partir dessa verdade dos fatos.

Quanto às reparações estipuladas pela Corte, para além das reparações de cunho indenizatório, é interessante notar as reparações simbólicas a que o tribunal obriga os Estados, determinando o desvelamento da verdade acerca das circunstâncias do desaparecimento, a devolução dos restos mortais do desaparecido em caso de constatação de morte para que a família possa elaborar seu luto, e aquelas reparações no sentido de preservação da memória do desaparecido, como a construção de memoriais, inscrição de placas em museus ou identificação de escola pública com o nome do desaparecido, entregues em cerimoniais com a presença dos familiares, sempre com vistas a não-repetição dos fatos. Nesse sentido, a Corte

\footnotetext{
${ }^{473}$ TODOROV, Tzvetan. Os limites da justiça. In CASSESSE, Antonio e DELMAS-MARTY, Mireille (orgs.) Crimes Internacionais e Jurisdições Internacionais. São Paulo: Manole, 2004, p. 37. Continua: “Ora, a justiça está mais bem equiparada para contribuir para o estabelecimento do primeiro tipo de verdade do que do segundo. Ela é capaz de reunir uma quantidade muito grande de informações, de controlá-las e ordená-las [...]. Em compensação, a justiça está mal adaptada para encontrar o segundo tipo de verdade, o que trata do sentido dos acontecimentos. A justiça não aspira a uma equidade histórica, ela instrui para acusar e defender: a verdade factual é colocada a serviço de um objetivo, ela é instrumentalizada”. Idem, pp. 37-8. Nessa perspectiva, pode-se analogamente depreender a responsabilidade que tem o direito, e por conseqüência os tribunais, de promoverem a verdade dos fatos, ou seja, de garantirem o direito à verdade, com o fim de oferecerem os elementos dos fatos para a construção de memórias, ou, continuando na terminologia do autor citado, as interpretações.
} 
propõe formas de transformação das memórias coletivas visando não somente a uma satisfação das vítimas, mas a recusa ao esquecimento da atrocidade cometida no passado que, se não lembrada, pode ser repetida no presente ou futuro.

Considerando que o desaparecimento forçado de pessoas constituiu-se instrumento de política autoritária, próprio de regimes ditatoriais, a pergunta que se coloca frente ao desafio de construção de memórias é como resgatar os cortes propostos por aquele regime, ou, em outros termos, o que não foi dito às gerações futuras? É preciso permitir que as sombras do passado possam povoar mais as sociedades, em uma perspectiva de considerar a condição de errantes dessas democracias recentes. Com isso se aposta na possibilidade de invenção de outras formas de relação, gerando nessas sociedades um sentimento maior de responsabilidade pelo destino de si e das gerações vindouras. 


\section{BIBLIOGRAFIA}

\section{Livros e artigos}

ALMEIDA, Guilherme Assis de e MOISÉS, Cláudia Perrone (org.). Direito Internacional dos Direitos Humanos. São Paulo: Atlas, 2002.

ALVES, José Augusto Lindgren. Direitos Humanos como tema global. São Paulo: Perspectiva, 2003.

AMNESTY INTERNACIONAL. Les disparus : rapport sur une nouvelle technique de repression. Éditions du Seuil, 1981.

. Desapariciones forzadas y homicídios politicos: La crise de los derechos humanos em los noventa. Madri: EDAI, 1994.

ANDORNO, Roberto. The paradoxical notion of human dignity. In Rivista Internazionali di filosofia Del diritto, 2001.

ARENDT, Hannah. Eichmann em Jerusalém - Um relato sobre a banalidade do mal. São Paulo: Companhia das Letras, 1999.

. O que é política? Rio de Janeiro: Bertrand Brasil, 1999.

. Origens do Totalitarismo. São Paulo: Companhia das Letras, 1989.

2004. . Os documentos do Pentágono. In Crises da República. São Paulo: Perspectiva, . Responsabilidade e Julgamento. São Paulo: Companhia das Letras, 2004.

. Verdade e Política. In Entre o passado e o Futuro. São Paulo: Perspectiva, 2003.

ASCENSIO, Hervé; DECAUX, Emmanuel e PELLET, Allain (orgs.). Droit International Pénal. Paris: A. Pedone, 2000.

AZZALI, Javier Carlos. Memoria colectiva y discurso jurídico. In Revista Crítica Jurídica, n. 20, jan-jul 2002

BASTOS, Lucia Elena Arantes Ferreira. As leis de anistia face ao direito internacional. $O$ caso brasileiro. Tese de doutorado apresentada no Departamento de Direito Internacional da Faculdade de Direito, USP, 2007.

BOBBIO, Norberto. A democracia e o poder invisível. In: O futuro da democracia. São Paulo: Paz e terra, 2000, 11 a . ed., p. 98.

. A Era dos Direitos. Rio de Janeiro: Campus, 1992.

BRODY, Reed e GONZÁLES, Felipe. Nunca más: an analyses of international instruments on “disappearances". In Human Rights quartely, vol. 19, maio 1997.

CASSESSE, Antonio. International Criminal Law. In International Law. Oxford: Malcom D. Evans, 2003.

CATELA, Ludmila da Silva. Derechos humanos y memoria. Historia y dilemas de uma relación particular. $8^{\circ}$. Congresso Argentino de Antropologia Social, 19-22 de setembro de 2006. 
. Situação limite e memória: reconstrução do mundo dos familiares de desaparecidos da Argentina. São Paulo: Hucitec/ Anpocs, 2001.

CEJIL. Justicia y paz em Colombia: El derecho a La verdad, La justicia y La reparación. San Jose: CEJIL, 2006.

COMITÉ INTERNACIONAL DE LA CRUZ ROJA. Prácticas operacionales idôneas em relación com el tratamiento de los restos humanos y de la información sobre los fallecidos para personal no especializado: para todas lãs fuerzas armadas, para todas lãs organizaciones humanitárias. Genebra: CICR, 2004.

COMITÊ INTERNACIONAL DA CRUZ VERMELHA, Droit International Humanitaire. Réponses à vos questions. Genebra: CICR, 2a . ed., 2004.

COMPARATO, Fábio Konder. Que fizeste de teu irmão? In: TELES, Janaína (org.). Mortos e Desaparecidos Políticos: Reparação ou Impunidade? São Paulo: Humanitas, 2001, $2^{\text {a }}$ ed.

DELMAS-MARTY, Mireille. Os crimes internacionais podem contribuir para o debate entre universalismo e relativismo de valores? In: CASSESSE, Antonio e DELMAS-MARTY, Mireille (orgs.) Crimes Internacionais e Jurisdições Internacionais. São Paulo: Manole, 2004. Por um direito comum. São Paulo: Martins Fontes, 2004.

DONGEN, Toine van. The UN working group on enforced or involuntary disappearances. In Studie-en Informatioecentrum Mensenrechten. Maastricht, 1992.

GAGNEBIN, Jeanne Marie. Lembrar escrever esquecer. São Paulo: 34, 2006.

GARAPON, Antoine. Des crimes qu'on ne peut ni punir ni pardonner: pour une justice internationale. Paris: Odile Jacob, 2002.

HALBWACHS. Maurice. A memória coletiva. São Paulo: Centauro, 2006.

JARDIM, Tarciso Dal Maso. Crime do desaparecimento forçado de pessoas. Brasília: Brasília Jurídica, 1999.

KLEINMAN, Howard. Disappearances in Latin América: a human rights perspective. In: Journal of International law and politics. Nova York, 1987.

LAFER, Celso. A reconstrução dos direitos humanos: um diálogo com o pensamento de Hannah Arendt. São Paulo: Companhia das Letras, 1998.

LE GOFF, Jacques. História e Memória. Campinas: Unicamp, 5ª Ed., 2003.

LIVERMORE, J. Daniel e RAMCHARAN, B. G. Enforced or involuntary disappearances: na evaluation of a decade of United Nations action. In Canadian Human Rights Yearbook. 19891990.

MARTIN, Sophie. The missing. In International Review of the Red Cross. Humanitarian debate: law, policy, action. Vol. 84, 2002.

NAQVI, Yasmin. The right to the truth in international law: fact or fiction? In International Review of the Red Cross, vol. 88, n. 862, jun. 2006.

PARAYRE, Sonia. La desaparición forzada de personas como violación continuada de derechos humanos y su incidência en la determinación de la competência ratione temporis de la corte interamericana de derechos humanos. In IDDH. Vol. 29, 1999.

PERRONE-MOISÉS, Cláudia. Imunidades de chefes de Estado e crimes internacionais. Tese de Livre Docência apresentada na Faculdade de Direito da USP, 2009. 
O exercício do direito à verdade no Brasil pós-ditadura militar. In BENEVIDES, Maria Victoria de Mesquita; BERCOVICI, Gilberto e MELO, Claudineu de. Direitos Humanos, Democracia e República: Homenagem a Fábio Konder Comparato. São Paulo: Quartier Latin, 2009.

. Hannah Arendt e o longo curso da maldade humana. In: Jornal da Tarde, Caderno de Sábado, 04 de março de 2000.

Leis de anistia face ao Direito Internacional: "desaparecimentos" e "direito à verdade". In: PIOVESAN, Flávia (org.). Direitos humanos, globalização econômica e integração regional: desafios do direito constitucional internacional. São Paulo: Max Limonad, 2002.

. Verdade, opinião, mentira. In Hannah Arendt Handbook, 2008, no prelo.

. O perdão e os crimes contra a humanidade - um diálogo entre Hannah Arendt e Jacques Derrida. In: CORREIA, Adriano (org.). Hannan Arendt e a Condição Humana. Salvador: Quarteto, 2006.

PIOVESAN, Flávia. Direitos Humanos e o Direito Constitucional Internacional. São Paulo: Max Limonad, 2002.

.Temas de direitos humanos. São Paulo: Max Limonad, 1998.

POLLAK, Michael. Memoria, olvido, silencio. La producción social de identidades frente a situaciones limite. La Plata: Ediciones Al Margen, 2006.

RAMOS, André de Carvalho. Responsabilidade Internacional por violação de Direitos Humanos: seus elementos, a reparação devida e as sanções possíveis: teoria e prática. Rio de Janeiro, Renovar, 2004.

Direitos Humanos em juízo. Comentários aos casos contenciosos e consultivos da Corte Interamericana de Direitos Humanos. São Paulo, Max Limonad, 2001.

REOCH, Richard. "Disappearances" and the international protection of human rights. In: The year book of world affairs. Londres: Stevens \& Sons, 1982.

RICOUER, Paul. A memória, a história e o esquecimento. Campinas: Unicamp, 2007

ROJAS, Manuel Hinojo. Al hilo de la Declaración de 1992 de La Asamblea General de Naciones Unidas sobre la protección de todas las personas contra lãs desapariciones forzadas. In Anuario de Derecho Internacional, Universidad de Navarra, Pamplona, 1996.

SAMPAIO, José Adércio Leite e ALMEIDA, Alex Luciano Valadares de. Verdade e história: por um direito fundamental à verdade. In SOARES, Inês Virgínia Prado e KISHI, Sandra Akemi Shimada. Memória e Verdade - A justiça de transição no Estado Democrático Brasileiro. Belo Horizonte: Fórum, 2009.

SASSÒLI, Marco e TOUGAS, Marie-Louise. The ICRC and the missing. In International Review of the Red Cross. Humanitarian debate: law, policy, action. Vol. 84, 2002

SELIGMANN-SILVA, Marcio (org.). História Memória Literatura. O testemunho na era das catástrofes. Campinas: Unicamp, 2003.

SWINARSKI, Christophe. Introdução ao direito Internacional Humanitário. Brasília: Comitê Internacional da Cruz Vermelha e Instituto Interamericano de Direitos Humanos, 1993.

TELES, Edson Luis de Almeida. Brasil e África do Sul: rupturas e continuidades nas transições políticas. In SOARES, Inês Virgínia Prado e KISHI, Sandra Akemi Shimada. 
Memória e Verdade - A justiça de transição no Estado Democrático Brasileiro. Belo Horizonte: Fórum, 2009.

TODOROV, Tzvetan. Os limites da justiça. In CASSESSE, Antonio e DELMAS-MARTY, Mireille (orgs.) Crimes Internacionais e Jurisdições Internacionais. São Paulo: Manole, 2004.

TOURAINE, Alain. Memoria, historia, futuro. In ACADEMIA UNIVERSAL DE LAS

CULTURAS. Por qué recordar? Buenos Aires: Granica, 2006.

TELES, Janaína. Mortos e desaparecidos políticos: reparação ou impunidade? São Paulo: Humanitas, 2001.

\section{Documentos Internacionais}

Em âmbito da ONU os documentos podem ser localizados no sítio:

http://documents.un.org/simple.asp

A/CONF.157/24 (Part I)

$\mathrm{A} / \mathrm{HRC} / 4 / 41$

A/HRC/10/9

A/RES/33/173

A/RES/47/133

A/CONF.183/9

A/RES/61/177

A/RES/34/178

A/RES/34/179

A/RES/A/34/583/Add.1

A/RES/1988/17

A/RES/60/147

E/CN.4/1492

E/CN.4/1435

E/CN.4/1983/14

E/CN.4/1984/21

E/CN.4/1985/15/Add 1.

E/CN.4/1987/15

E/CN.4/1988/19

E/CN.4/1988/19/Add. 1

E/CN.4/1989/18

E/CN.4/Sub.2/1988/28, anexo 
E/CN.4/Sub.2/1989/29/Rev.1.

E/CN.4/1989/19/Add.1

E/CN.4/1990/13

E/CN.4/Sub.2/1990/WG.1/Add.1.

E/CN.4/1990/13

E/CN.4/1991/20

E/CN.4/1991/20/Add.1.

E/CN.4/1992/18

E/CN.4/1992/18/Add.1.

E/CN.4/1993/25

E/CN.4/1994/26

E/CN.4/1996/38

E/CN.4/1997/34

E/CN.4/1998/43

E/CN.4/2002/79

E/CN.4/2002/71

E/CN.4/2006/56

E/CN.4/Sub.2/1997/20/Rev.1

E/CN.4/1998/53/Add.2

E/CN.4/2006/91

E/CN.4/Sub.2/1997/20/Rev.1

E/CN.4/2005/102/Add.1

E/CN.4/Sub.2/1997/20/Rev.1

Em âmbito da OEA os documentos podem ser encontrados no sítio:

https://www.apps.oas.org/publicsearch/default.asp

AG/doc.3072/94

AG/RES.890(XVII-0/87)

AG/RES.950(XVIII-0/88)

AG/RES.1014(XIX-0/89)

AG/RES.1033(XX-0/90)

AG/RES.1172(XXII-0/92)

AG/RES. 2267 (XXXVII-O/07) 


\section{Casos da Corte Interamericana de Direitos Humanos}

Os casos contenciosos julgados pela Corte Interamericana podem ser encontrados no sítio: http://www.corteidh.or.cr/docs/casos/

Velásquez Rodríguez vs. Honduras

Godínez Cruz vs. Honduras

Fairén Garbi e Solís Corrales vs. Honduras

Neira Alegría vs. Peru

Caballero Delgado e Santana vs. Colômbia

Blake vs. Guatemala

"Panel Blanca" (Paniagua Morales e outros) vs. Guatemala

Trujillo Oroza vs. Bolívia

Durand e Ugarte vs. Peru

Bámaca Velásquez vs. Guatemala

Caracazo vs. Venezuela

Juan Humberto Sánchez vs. Honduras

Molina Theissen vs. Guatemala

19 Comerciantes vs. Colômbia

Irmãs Serrano Cruz vs. El Salvador

“Masacre de Mapiripán” vs. Colômbia

Gómez Palomino vs. Peru

Blanco Romero e outros vs. Venezuela

Goiburú e outros vs. Paraguai

La Cantuta vs. Peru

Heliodoro Portugal vs. Panamá

Tiu Tojín vs. Guatemala

Ticona Estrada e outros vs. Bolívia

Anzualdo Castro vs. Peru 


\section{AnEXOS}

1. Casos da Corte Interamericana disponibilizados no sítio em 30 de janeiro de 2010

Caso "Instituto de Reeducación del Menor" Vs. Paraguay.

Caso "La Última Tentación de Cristo" (Olmedo Bustos y otros) Vs. Chile.

Caso Acevedo Buendía y otros ("Cesantes y Jubilados de la Contraloría") Vs. Perú.

Caso Acevedo Jaramillo y otros Vs. Perú.

Caso Acosta Calderón Vs. Ecuador.

Caso Albán Cornejo y otros. Vs. Ecuador.

Caso Alfonso Martín del Campo Dodd Vs. México.

Caso Almonacid Arellano y otros Vs. Chile.

Caso Aloeboetoe y otros Vs. Surinam.

Caso Anzualdo Castro Vs. Perú.

Caso Apitz Barbera y otros ("Corte Primera de lo Contencioso Administrativo") Vs. Venezuela.

Caso Baena Ricardo y otros Vs. Panamá.

Caso Baldeón García Vs. Perú.

Caso Bámaca Velásquez Vs. Guatemala.

Caso Barreto Leiva Vs. Venezuela.

Caso Barrios Altos Vs. Perú.

Caso Bayarri Vs. Argentina.

Caso Benavides Cevallos Vs. Ecuador.

Caso Benjamin y otros Vs. Trinidad y Tobago.

Caso Blake Vs. Guatemala.

Caso Blanco Romero y otros Vs. Venezuela.

Caso Boyce y otros Vs. Barbados.

Caso Bueno Alves Vs. Argentina.

Caso Bulacio Vs. Argentina.

Caso Caballero Delgado y Santana Vs. Colombia.

Caso Caesar Vs. Trinidad y Tobago.

Caso Cantoral Benavides Vs. Perú.

Caso Cantoral Huamaní y García Santa Cruz Vs. Perú.

Caso Cantos Vs. Argentina.

Caso Carpio Nicolle y otros Vs. Guatemala.

Caso Castañeda Gutman Vs. México.

Caso Castillo Páez Vs. Perú.

Caso Castillo Petruzzi y otros Vs. Perú.

Caso Cayara Vs. Perú.

Caso Cesti Hurtado Vs. Perú.

Caso Chaparro Álvarez y Lapo Íñiguez. Vs. Ecuador.

Caso Cinco Pensionistas Vs. Perú. 
Caso Claude Reyes y otros Vs. Chile.

Caso Comunidad Indígena Sawhoyamaxa Vs. Paraguay.

Caso Comunidad Indígena Yakye Axa Vs. Paraguay.

Caso Constantine y otros Vs. Trinidad y Tobago.

Caso Dacosta Cadogan Vs. Barbados.

Caso de la "Panel Blanca" (Paniagua Morales y otros) Vs. Guatemala.

Caso de la Comunidad Mayagna (Sumo) Awas Tingni Vs. Nicaragua.

Caso de la Comunidad Moiwana Vs. Surinam.

Caso De la Cruz Flores Vs. Perú.

Caso de la Masacre de la Rochela Vs. Colombia.

Caso De la Masacre de las Dos Erres Vs. Guatemala.

Caso de la Masacre de Mapiripán Vs. Colombia.

Caso de la Masacre de Pueblo Bello Vs. Colombia.

Caso de las Hermanas Serrano Cruz Vs. El Salvador.

Caso de las Masacres de Ituango Vs. Colombia.

Caso de las Niñas Yean y Bosico Vs. República Dominicana.

Caso de los "Niños de la Calle" (Villagrán Morales y otros) Vs. Guatemala.

Caso de los 19 Comerciantes Vs. Colombia.

Caso de los Hermanos Gómez Paquiyauri Vs. Perú.

Caso del Caracazo Vs. Venezuela.

Caso del Penal Miguel Castro Castro Vs. Perú.

Caso del Pueblo Saramaka. Vs. Surinam.

Caso del Tribunal Constitucional Vs. Perú.

Caso Durand y Ugarte Vs. Perú.

Caso El Amparo Vs. Venezuela.

Caso Escher y otros Vs. Brasil.

Caso Escué Zapata Vs. Colombia.

Caso Fairén Garbi y Solís Corrales Vs. Honduras.

Caso Fermín Ramírez Vs. Guatemala.

Caso Gangaram Panday Vs. Surinam.

Caso García Asto y Ramírez Rojas Vs. Perú.

Caso García Prieto y otros Vs. El Salvador.

Caso Garibaldi Vs. Brasil.

Caso Garrido y Baigorria Vs. Argentina.

Caso Genie Lacayo Vs. Nicaragua.

Caso Godínez Cruz Vs. Honduras.

Caso Goiburú y otros Vs. Paraguay.

Caso Gómez Palomino Vs. Perú.

Caso González y otras ("Campo Algodonero") Vs. México.

Caso Gutiérrez Soler Vs. Colombia.

Caso Heliodoro Portugal Vs. Panamá.

Caso Herrera Ulloa Vs. Costa Rica.

Caso Hilaire Vs. Trinidad y Tobago.

Caso Huilca Tecse Vs. Perú. 
Caso Ivcher Bronstein Vs. Perú.

Caso Juan Humberto Sánchez Vs. Honduras.

Caso Kawas Fernández Vs. Honduras.

Caso Kimel Vs. Argentina.

Caso La Cantuta Vs. Perú.

Caso Las Palmeras Vs. Colombia.

Caso Loayza Tamayo Vs. Perú.

Caso López Álvarez Vs. Honduras.

Caso Lori Berenson Mejía Vs. Perú.

Caso Maqueda Vs. Argentina.

Caso Maritza Urrutia Vs. Guatemala.

Caso Masacre Plan de Sánchez Vs. Guatemala.

Caso Molina Theissen Vs. Guatemala.

Caso Montero Aranguren y otros (Retén de Catia) Vs. Venezuela.

Caso Myrna Mack Chang Vs. Guatemala.

Caso Neira Alegría y otros Vs. Perú.

Caso Nogueira de Carvalho y otro Vs. Brasil.

Caso Palamara Iribarne Vs. Chile.

Caso Perozo y otros Vs. Venezuela.

Caso Radilla Pacheco Vs. México.

Caso Raxcacó Reyes Vs. Guatemala.

Caso Reverón Trujillo Vs. Venezuela.

Caso Ricardo Canese Vs. Paraguay.

Caso Ríos y otros Vs. Venezuela.

Caso Salvador Chiriboga Vs. Ecuador.

Caso Servellón García y otros Vs. Honduras.

Caso Suárez Rosero Vs. Ecuador.

Caso Tibi Vs. Ecuador.

Caso Ticona Estrada y otros Vs. Bolivia.

Caso Tiu Tojín Vs. Guatemala.

Caso Trabajadores Cesados del Congreso (Aguado Alfaro y otros). Vs. Perú.

Caso Tristán Donoso Vs. Panamá.

Caso Trujillo Oroza Vs. Bolivia.

Caso Usón Ramírez Vs. Venezuela.

Caso Valle Jaramillo y otros Vs. Colombia.

Caso Vargas Areco Vs. Paraguay.

Caso Velásquez Rodríguez Vs. Honduras.

Caso Ximenes Lopes Vs. Brasil.

Caso Yatama Vs. Nicaragua.

Caso Yvon Neptune Vs. Haití.

Caso Zambrano Vélez y otros Vs. Ecuador. 


\section{Convenção Americana de Direitos Humanos}

\section{PREÂMBULO}

Os Estados Americanos signatários da presente Convenção,

Reafirmando seu propósito de consolidar neste Continente, dentro do quadro das instituições democráticas, um regime de liberdade pessoal e de justiça social, fundado no respeito dos direitos humanos essenciais;

Reconhecendo que os direitos essenciais da pessoa humana não derivam do fato de ser ela nacional de determinado Estado, mas sim do fato de ter como fundamento os atributos da pessoa humana, razão por que justificam uma proteção internacional, de natureza convencional, coadjuvante ou complementar da que oferece o direito interno dos Estados americanos;

Considerando que esses princípios foram consagrados na Carta da Organização dos Estados Americanos, na Declaração Americana dos Direitos e Deveres do Homem e na Declaração Universal dos Direitos do Homem, e que foram reafirmados e desenvolvidos em outros instrumentos internacionais, tanto de âmbito mundial como regional;

Reiterando que, de acordo com a Declaração Universal dos Direitos Humanos, só pode ser realizado o ideal do ser humano livre, isento do temor e da miséria, se forem criadas condições que permitam a cada pessoa gozar dos seus direitos econômicos, sociais e culturais, bem como dos seus direitos civis e políticos; e

Considerando que a Terceira Conferência Interamericana Extraordinária (Buenos Aires, 1967) aprovou a incorporação à própria Carta da Organização de normas mais amplas sobre os direitos econômicos, sociais e educacionais e resolveu que uma Convenção Interamericana sobre Direitos Humanos determinasse a estrutura, competência e processo dos órgãos encarregados dessa matéria;

Convieram no seguinte:

\section{PARTE I - DEVERES DOS ESTADOS E DIREITOS PROTEGIDOS}

\section{Capítulo I - ENUMERAÇÃO DOS DEVERES}

Artigo $1^{\circ}$ - Obrigação de respeitar os direitos

1. Os Estados-partes nesta Convenção comprometem-se a respeitar os direitos e liberdades nela reconhecidos e a garantir seu livre e pleno exercício a toda pessoa que esteja sujeita à sua jurisdição, sem discriminação alguma, por motivo de raça, cor, sexo, idioma, religião, 
opiniões políticas ou de qualquer outra natureza, origem nacional ou social, posição econômica, nascimento ou qualquer outra condição social.

2. Para efeitos desta Convenção, pessoa é todo ser humano.

Artigo $2^{\circ}$ - Dever de adotar disposições de direito interno

Se o exercício dos direitos e liberdades mencionados no artigo 1 ainda não estiver garantido por disposições legislativas ou de outra natureza, os Estados-partes comprometem-se a adotar, de acordo com as suas normas constitucionais e com as disposições desta Convenção, as medidas legislativas ou de outra natureza que forem necessárias para tornar efetivos tais direitos e liberdades.

\section{Capítulo II - DIREITOS CIVIS E POLÍTICOS}

Artigo $3^{\circ}$ - Direito ao reconhecimento da personalidade jurídica

Toda pessoa tem direito ao reconhecimento de sua personalidade jurídica.

Artigo $4^{\circ}$ - Direito à vida

1. Toda pessoa tem o direito de que se respeite sua vida. Esse direito deve ser protegido pela lei e, em geral, desde o momento da concepção. Ninguém pode ser privado da vida arbitrariamente.

2. Nos países que não houverem abolido a pena de morte, esta só poderá ser imposta pelos delitos mais graves, em cumprimento de sentença final de tribunal competente e em conformidade com a lei que estabeleça tal pena, promulgada antes de haver o delito sido cometido. Tampouco se estenderá sua aplicação a delitos aos quais não se aplique atualmente.

3. Não se pode restabelecer a pena de morte nos Estados que a hajam abolido.

4. Em nenhum caso pode a pena de morte ser aplicada a delitos políticos, nem a delitos comuns conexos com delitos políticos.

5. Não se deve impor a pena de morte a pessoa que, no momento da perpetração do delito, for menor de dezoito anos, ou maior de setenta, nem aplicá-la a mulher em estado de gravidez.

6. Toda pessoa condenada à morte tem direito a solicitar anistia, indulto ou comutação da pena, os quais podem ser concedidos em todos os casos. Não se pode executar a pena de morte enquanto o pedido estiver pendente de decisão ante a autoridade competente.

Artigo $5^{\circ}$ - Direito à integridade pessoal

1. Toda pessoa tem direito a que se respeite sua integridade física, psíquica e moral.

2. Ninguém deve ser submetido a torturas, nem a penas ou tratos cruéis, desumanos ou degradantes. Toda pessoa privada de liberdade deve ser tratada com o respeito devido à dignidade inerente ao ser humano.

3. A pena não pode passar da pessoa do delinquente. 
4. Os processados devem ficar separados dos condenados, salvo em circunstâncias excepcionais, e devem ser submetidos a tratamento adequado à sua condição de pessoas não condenadas.

5. Os menores, quando puderem ser processados, devem ser separados dos adultos e conduzidos a tribunal especializado, com a maior rapidez possível, para seu tratamento.

6. As penas privativas de liberdade devem ter por finalidade essencial a reforma e a readaptação social dos condenados.

Artigo $6^{\circ}$ - Proibição da escravidão e da servidão

1. Ninguém poderá ser submetido a escravidão ou servidão e tanto estas como o tráfico de escravos e o tráfico de mulheres são proibidos em todas as suas formas.

2. Ninguém deve ser constrangido a executar trabalho forçado ou obrigatório. Nos países em que se prescreve, para certos delitos, pena privativa de liberdade acompanhada de trabalhos forçados, esta disposição não pode ser interpretada no sentido de proibir o cumprimento da dita pena, imposta por um juiz ou tribunal competente. O trabalho forçado não deve afetar a dignidade, nem a capacidade física e intelectual do recluso.

3. Não constituem trabalhos forçados ou obrigatórios para os efeitos deste artigo:

a) os trabalhos ou serviços normalmente exigidos de pessoa reclusa em cumprimento de sentença ou resolução formal expedida pela autoridade judiciária competente. Tais trabalhos ou serviços devem ser executados sob a vigilância e controle das autoridades públicas, e os indivíduos que os executarem não devem ser postos à disposição de particulares, companhias ou pessoas jurídicas de caráter privado;

b) serviço militar e, nos países em que se admite a isenção por motivo de consciência, qualquer serviço nacional que a lei estabelecer em lugar daquele;

c) o serviço exigido em casos de perigo ou de calamidade que ameacem a existência ou o bem-estar da comunidade;

d) o trabalho ou serviço que faça parte das obrigações cívicas normais.

Artigo $7^{\circ}$ - Direito à liberdade pessoal

1. Toda pessoa tem direito à liberdade e à segurança pessoais.

2. Ninguém pode ser privado de sua liberdade física, salvo pelas causas e nas condições previamente fixadas pelas Constituições políticas dos Estados-partes ou pelas leis de acordo com elas promulgadas.

3. Ninguém pode ser submetido a detenção ou encarceramento arbitrários.

4. Toda pessoa detida ou retida deve ser informada das razões da detenção e notificada, sem demora, da acusação ou das acusações formuladas contra ela. 
5. Toda pessoa presa, detida ou retida deve ser conduzida, sem demora, à presença de um juiz ou outra autoridade autorizada por lei a exercer funções judiciais e tem o direito de ser julgada em prazo razoável ou de ser posta em liberdade, sem prejuízo de que prossiga o processo. Sua liberdade pode ser condicionada a garantias que assegurem o seu comparecimento em juízo.

6. Toda pessoa privada da liberdade tem direito a recorrer a um juiz ou tribunal competente, a fim de que este decida, sem demora, sobre a legalidade de sua prisão ou detenção e ordene sua soltura, se a prisão ou a detenção forem ilegais. Nos Estados-partes cujas leis prevêem que toda pessoa que se vir ameaçada de ser privada de sua liberdade tem direito a recorrer a um juiz ou tribunal competente, a fim de que este decida sobre a legalidade de tal ameaça, tal recurso não pode ser restringido nem abolido. $\mathrm{O}$ recurso pode ser interposto pela própria pessoa ou por outra pessoa.

7. Ninguém deve ser detido por dívidas. Este princípio não limita os mandados de autoridade judiciária competente expedidos em virtude de inadimplemento de obrigação alimentar. Artigo $8^{\circ}$ - Garantias judiciais

1. Toda pessoa terá o direito de ser ouvida, com as devidas garantias e dentro de um prazo razoável, por um juiz ou Tribunal competente, independente e imparcial, estabelecido anteriormente por lei, na apuração de qualquer acusação penal formulada contra ela, ou na determinação de seus direitos e obrigações de caráter civil, trabalhista, fiscal ou de qualquer outra natureza.

2. Toda pessoa acusada de um delito tem direito a que se presuma sua inocência, enquanto não for legalmente comprovada sua culpa. Durante o processo, toda pessoa tem direito, em plena igualdade, às seguintes garantias mínimas:

a) direito do acusado de ser assistido gratuitamente por um tradutor ou intérprete, caso não compreenda ou não fale a língua do juízo ou tribunal;

b) comunicação prévia e pormenorizada ao acusado da acusação formulada;

c) concessão ao acusado do tempo e dos meios necessários à preparação de sua defesa;

d) direito do acusado de defender-se pessoalmente ou de ser assistido por um defensor de sua escolha e de comunicar-se, livremente e em particular, com seu defensor;

e) direito irrenunciável de ser assistido por um defensor proporcionado pelo Estado, remunerado ou não, segundo a legislação interna, se o acusado não se defender ele próprio, nem nomear defensor dentro do prazo estabelecido pela lei;

f) direito da defesa de inquirir as testemunhas presentes no Tribunal e de obter o comparecimento, como testemunhas ou peritos, de outras pessoas que possam lançar luz sobre os fatos; 
g) direito de não ser obrigada a depor contra si mesma, nem a confessar-se culpada; e

h) direito de recorrer da sentença a juiz ou tribunal superior.

3. A confissão do acusado só é válida se feita sem coação de nenhuma natureza.

4. O acusado absolvido por sentença transitada em julgado não poderá ser submetido a novo processo pelos mesmos fatos.

5. O processo penal deve ser público, salvo no que for necessário para preservar os interesses da justiça.

Artigo $9^{\circ}$ - Princípio da legalidade e da retroatividade

Ninguém poderá ser condenado por atos ou omissões que, no momento em que foram cometidos, não constituam delito, de acordo com o direito aplicável. Tampouco poder-se-á impor pena mais grave do que a aplicável no momento da ocorrência do delito. Se, depois de perpetrado o delito, a lei estipular a imposição de pena mais leve, o deliquente deverá dela beneficiar-se.

Artigo 10 - Direito à indenização

Toda pessoa tem direito de ser indenizada conforme a lei, no caso de haver sido condenada em sentença transitada em julgado, por erro judiciário.

Artigo 11 - Proteção da honra e da dignidade

1. Toda pessoa tem direito ao respeito da sua honra e ao reconhecimento de sua dignidade.

2. Ninguém pode ser objeto de ingerências arbitrárias ou abusivas em sua vida privada, em sua família, em seu domicílio ou em sua correspondência, nem de ofensas ilegais à sua honra ou reputação.

3. Toda pessoa tem direito à proteção da lei contra tais ingerências ou tais ofensas.

Artigo 12 - Liberdade de consciência e de religião

1. Toda pessoa tem direito à liberdade de consciência e de religião. Esse direito implica a liberdade de conservar sua religião ou suas crenças, ou de mudar de religião ou de crenças, bem como a liberdade de professar e divulgar sua religião ou suas crenças, individual ou coletivamente, tanto em público como em privado.

2. Ninguém pode ser submetido a medidas restritivas que possam limitar sua liberdade de conservar sua religião ou suas crenças, ou de mudar de religião ou de crenças.

3. A liberdade de manifestar a própria religião e as próprias crenças está sujeita apenas às limitações previstas em lei e que se façam necessárias para proteger a segurança, a ordem, a saúde ou a moral públicas ou os direitos e as liberdades das demais pessoas.

4. Os pais e, quando for o caso, os tutores, têm direito a que seus filhos e pupilos recebam a educação religiosa e moral que esteja de acordo com suas próprias convicções. 
Artigo 13 - Liberdade de pensamento e de expressão

1. Toda pessoa tem o direito à liberdade de pensamento e de expressão. Esse direito inclui a liberdade de procurar, receber e difundir informações e idéias de qualquer natureza, sem considerações de fronteiras, verbalmente ou por escrito, ou em forma impressa ou artística, ou por qualquer meio de sua escolha.

2. O exercício do direito previsto no inciso precedente não pode estar sujeito à censura prévia, mas a responsabilidades ulteriores, que devem ser expressamente previstas em lei e que se façam necessárias para assegurar:

a) o respeito dos direitos e da reputação das demais pessoas;

b) a proteção da segurança nacional, da ordem pública, ou da saúde ou da moral públicas.

3. Não se pode restringir o direito de expressão por vias e meios indiretos, tais como o abuso de controles oficiais ou particulares de papel de imprensa, de frequências radioelétricas ou de equipamentos e aparelhos usados na difusão de informação, nem por quaisquer outros meios destinados a obstar a comunicação e a circulação de idéias e opiniões.

4. A lei pode submeter os espetáculos públicos a censura prévia, com o objetivo exclusivo de regular o acesso a eles, para proteção moral da infância e da adolescência, sem prejuízo do disposto no inciso 2 .

5. A lei deve proibir toda propaganda a favor da guerra, bem como toda apologia ao ódio nacional, racial ou religioso que constitua incitamento à discriminação, à hostilidade, ao crime ou à violência.

Artigo 14 - Direito de retificação ou resposta

1. Toda pessoa, atingida por informações inexatas ou ofensivas emitidas em seu prejuízo por meios de difusão legalmente regulamentados e que se dirijam ao público em geral, tem direito a fazer, pelo mesmo órgão de difusão, sua retificação ou resposta, nas condições que estabeleça a lei.

2. Em nenhum caso a retificação ou a resposta eximirão das outras responsabilidades legais em que se houver incorrido.

3. Para a efetiva proteção da honra e da reputação, toda publicação ou empresa jornalística, cinematográfica, de rádio ou televisão, deve ter uma pessoa responsável, que não seja protegida por imunidades, nem goze de foro especial.

Artigo 15 - Direito de reunião

É reconhecido o direito de reunião pacífica e sem armas. O exercício desse direito só pode estar sujeito às restrições previstas em lei e que se façam necessárias, em uma sociedade 
democrática, ao interesse da segurança nacional, da segurança ou ordem públicas, ou para proteger a saúde ou a moral públicas ou os direitos e as liberdades das demais pessoas.

Artigo 16 - Liberdade de associação

1. Todas as pessoas têm o direito de associar-se livremente com fins ideológicos, religiosos, políticos, econômicos, trabalhistas, sociais, culturais, desportivos ou de qualquer outra natureza.

2. O exercício desse direito só pode estar sujeito às restrições previstas em lei e que se façam necessárias, em uma sociedade democrática, ao interesse da segurança nacional, da segurança e da ordem públicas, ou para proteger a saúde ou a moral públicas ou os direitos e as liberdades das demais pessoas.

3. O presente artigo não impede a imposição de restrições legais, e mesmo a privação do exercício do direito de associação, aos membros das forças armadas e da polícia.

Artigo 17 - Proteção da família

1. A família é o núcleo natural e fundamental da sociedade e deve ser protegida pela sociedade e pelo Estado.

2. É reconhecido o direito do homem e da mulher de contraírem casamento e de constituírem uma família, se tiverem a idade e as condições para isso exigidas pelas leis internas, na medida em que não afetem estas o princípio da não-discriminação estabelecido nesta Convenção.

3. O casamento não pode ser celebrado sem o consentimento livre e pleno dos contraentes.

4. Os Estados-partes devem adotar as medidas apropriadas para assegurar a igualdade de direitos e a adequada equivalência de responsabilidades dos cônjuges quanto ao casamento, durante o mesmo e por ocasião de sua dissolução. Em caso de dissolução, serão adotadas as disposições que assegurem a proteção necessária aos filhos, com base unicamente no interesse e conveniência dos mesmos.

5. A lei deve reconhecer iguais direitos tanto aos filhos nascidos fora do casamento, como aos nascidos dentro do casamento.

Artigo 18 - Direito ao nome

Toda pessoa tem direito a um prenome e aos nomes de seus pais ou ao de um destes. A lei deve regular a forma de assegurar a todos esse direito, mediante nomes fictícios, se for necessário.

Artigo 19 - Direitos da criança

Toda criança terá direito às medidas de proteção que a sua condição de menor requer, por parte da sua família, da sociedade e do Estado. 
Artigo 20 - Direito à nacionalidade

1. Toda pessoa tem direito a uma nacionalidade.

2. Toda pessoa tem direito à nacionalidade do Estado em cujo território houver nascido, se não tiver direito a outra.

3. A ninguém se deve privar arbitrariamente de sua nacionalidade, nem do direito de mudá-la.

Artigo 21 - Direito à propriedade privada

1. Toda pessoa tem direito ao uso e gozo de seus bens. A lei pode subordinar esse uso e gozo ao interesse social.

2. Nenhuma pessoa pode ser privada de seus bens, salvo mediante o pagamento de indenização justa, por motivo de utilidade pública ou de interesse social e nos casos e na forma estabelecidos pela lei.

3. Tanto a usura, como qualquer outra forma de exploração do homem pelo homem, devem ser reprimidas pela lei.

Artigo 22 - Direito de circulação e de residência

1. Toda pessoa que se encontre legalmente no território de um Estado tem o direito de nele livremente circular e de nele residir, em conformidade com as disposições legais.

2. Toda pessoa terá o direito de sair livremente de qualquer país, inclusive de seu próprio país. 3. O exercício dos direitos supracitados não pode ser restringido, senão em virtude de lei, na medida indispensável, em uma sociedade democrática, para prevenir infrações penais ou para proteger a segurança nacional, a segurança ou a ordem públicas, a moral ou a saúde públicas, ou os direitos e liberdades das demais pessoas.

4. O exercício dos direitos reconhecidos no inciso 1 pode também ser restringido pela lei, em zonas determinadas, por motivo de interesse público.

5. Ninguém pode ser expulso do território do Estado do qual for nacional e nem ser privado do direito de nele entrar.

6. O estrangeiro que se encontre legalmente no território de um Estado-parte na presente Convenção só poderá dele ser expulso em decorrência de decisão adotada em conformidade com a lei.

7. Toda pessoa tem o direito de buscar e receber asilo em território estrangeiro, em caso de perseguição por delitos políticos ou comuns conexos com delitos políticos, de acordo com a legislação de cada Estado e com as Convenções internacionais.

8. Em nenhum caso o estrangeiro pode ser expulso ou entregue a outro país, seja ou não de origem, onde seu direito à vida ou à liberdade pessoal esteja em risco de violação em virtude de sua raça, nacionalidade, religião, condição social ou de suas opiniões políticas. 
9. É proibida a expulsão coletiva de estrangeiros.

Artigo 23 - Direitos políticos

1. Todos os cidadãos devem gozar dos seguintes direitos e oportunidades:

a) de participar da condução dos assuntos públicos, diretamente ou por meio de representantes livremente eleitos;

b) de votar e ser eleito em eleições periódicas, autênticas, realizadas por sufrágio universal e igualitário e por voto secreto, que garantam a livre expressão da vontade dos eleitores; e

c) de ter acesso, em condições gerais de igualdade, às funções públicas de seu país.

2. A lei pode regular o exercício dos direitos e oportunidades, a que se refere o inciso anterior, exclusivamente por motivo de idade, nacionalidade, residência, idioma, instrução, capacidade civil ou mental, ou condenação, por juiz competente, em processo penal.

Artigo 24 - Igualdade perante a lei

Todas as pessoas são iguais perante a lei. Por conseguinte, têm direito, sem discriminação alguma, à igual proteção da lei.

Artigo 25 - Proteção judicial

1. Toda pessoa tem direito a um recurso simples e rápido ou a qualquer outro recurso efetivo, perante os juízes ou tribunais competentes, que a proteja contra atos que violem seus direitos fundamentais reconhecidos pela Constituição, pela lei ou pela presente Convenção, mesmo quando tal violação seja cometida por pessoas que estejam atuando no exercício de suas funções oficiais.

2. Os Estados-partes comprometem-se:

a) a assegurar que a autoridade competente prevista pelo sistema legal do Estado decida sobre os direitos de toda pessoa que interpuser tal recurso;

b) a desenvolver as possibilidades de recurso judicial; e

c) a assegurar o cumprimento, pelas autoridades competentes, de toda decisão em que se tenha considerado procedente o recurso.

\section{Capítulo III - DIREITOS ECONÔMICOS, SOCIAIS E CULTURAIS}

Artigo 26 - Desenvolvimento progressivo

Os Estados-partes comprometem-se a adotar as providências, tanto no âmbito interno, como mediante cooperação internacional, especialmente econômica e técnica, a fim de conseguir progressivamente a plena efetividade dos direitos que decorrem das normas econômicas, sociais e sobre educação, ciência e cultura, constantes da Carta da Organização dos Estados Americanos, reformada pelo Protocolo de Buenos Aires, na medida dos recursos disponíveis, por via legislativa ou por outros meios apropriados. 


\section{Capítulo IV - SUSPENSÃO DE GARANTIAS, INTERPRETAÇÃO E APLICAÇÃO}

Artigo 27 - Suspensão de garantias

1. Em caso de guerra, de perigo público, ou de outra emergência que ameace a independência ou segurança do Estado-parte, este poderá adotar as disposições que, na medida e pelo tempo estritamente limitados às exigências da situação, suspendam as obrigações contraídas em virtude desta Convenção, desde que tais disposições não sejam incompatíveis com as demais obrigações que lhe impõe o Direito Internacional e não encerrem discriminação alguma fundada em motivos de raça, cor, sexo, idioma, religião ou origem social.

2. A disposição precedente não autoriza a suspensão dos direitos determinados nos seguintes artigos: 3 (direito ao reconhecimento da personalidade jurídica), 4 (direito à vida), 5 (direito à integridade pessoal), 6 (proibição da escravidão e da servidão), 9 (princípio da legalidade e da retroatividade), 12 (liberdade de consciência e religião), 17 (proteção da família), 18 (direito ao nome), 19 (direitos da criança), 20 (direito à nacionalidade) e 23 (direitos políticos), nem das garantias indispensáveis para a proteção de tais direitos.

3. Todo Estado-parte no presente Pacto que fizer uso do direito de suspensão deverá comunicar imediatamente aos outros Estados-partes na presente Convenção, por intermédio do Secretário Geral da Organização dos Estados Americanos, as disposições cuja aplicação haja suspendido, os motivos determinantes da suspensão e a data em que haja dado por terminada tal suspensão.

Artigo 28 - Cláusula federal

1. Quando se tratar de um Estado-parte constituído como Estado federal, o governo nacional do aludido Estado-parte cumprirá todas as disposições da presente Convenção, relacionadas com as matérias sobre as quais exerce competência legislativa e judicial.

2. No tocante às disposições relativas às matérias que correspondem à competência das entidades componentes da federação, o governo nacional deve tomar imediatamente as medidas pertinentes, em conformidade com sua Constituição e com suas leis, a fim de que as autoridades competentes das referidas entidades possam adotar as disposições cabíveis para o cumprimento desta Convenção.

3. Quando dois ou mais Estados-partes decidirem constituir entre eles uma federação ou outro tipo de associação, diligenciarão no sentido de que o pacto comunitário respectivo contenha as disposições necessárias para que continuem sendo efetivas no novo Estado, assim organizado, as normas da presente Convenção.

Artigo 29 - Normas de interpretação

Nenhuma disposição da presente Convenção pode ser interpretada no sentido de: 
a) permitir a qualquer dos Estados-partes, grupo ou indivíduo, suprimir o gozo e o exercício dos direitos e liberdades reconhecidos na Convenção ou limitá-los em maior medida do que a nela prevista;

b) limitar o gozo e exercício de qualquer direito ou liberdade que possam ser reconhecidos em virtude de leis de qualquer dos Estados-partes ou em virtude de Convenções em que seja parte um dos referidos Estados;

c) excluir outros direitos e garantias que são inerentes ao ser humano ou que decorrem da forma democrática representativa de governo;

d) excluir ou limitar o efeito que possam produzir a Declaração Americana dos Direitos e Deveres do Homem e outros atos internacionais da mesma natureza.

Artigo 30 - Alcance das restrições

As restrições permitidas, de acordo com esta Convenção, ao gozo e exercício dos direitos e liberdades nela reconhecidos, não podem ser aplicadas senão de acordo com leis que forem promulgadas por motivo de interesse geral e com o propósito para o qual houverem sido estabelecidas.

Artigo 31 - Reconhecimento de outros direitos

Poderão ser incluídos, no regime de proteção desta Convenção, outros direitos e liberdades que forem reconhecidos de acordo com os processos estabelecidos nos artigo 69 e 70.

\section{Capítulo V - DEVERES DAS PESSOAS}

Artigo 32 - Correlação entre deveres e direitos

1. Toda pessoa tem deveres para com a família, a comunidade e a humanidade.

2. Os direitos de cada pessoa são limitados pelos direitos dos demais, pela segurança de todos e pelas justas exigências do bem comum, em uma sociedade democrática.

PARTE II - MEIOS DE PROTEÇÃO

Capítulo VI - ÓRGÃOS COMPETENTES

Artigo 33 - São competentes para conhecer de assuntos relacionados com o cumprimento dos compromissos assumidos pelos Estados-partes nesta Convenção:

a) a Comissão Interamericana de Direitos Humanos, doravante denominada a Comissão; e

b) a Corte Interamericana de Direitos Humanos, doravante denominada a Corte.

Capítulo VII - COMISSÃO INTERAMERICANA DE DIREITOS HUMANOS

Seção 1 - Organização

Artigo 34 - A Comissão Interamericana de Direitos Humanos compor-se-á de sete membros, que deverão ser pessoas de alta autoridade moral e de reconhecido saber em matéria de direitos humanos. 
Artigo 35 - A Comissão representa todos os Membros da Organização dos Estados Americanos.

Artigo 36 - 1. Os membros da Comissão serão eleitos a título pessoal, pela Assembléia Geral da Organização, a partir de uma lista de candidatos propostos pelos governos dos Estadosmembros.

2. Cada um dos referidos governos pode propor até três candidatos, nacionais do Estado que os propuser ou de qualquer outro Estado-membro da Organização dos Estados Americanos. Quando for proposta uma lista de três candidatos, pelo menos um deles deverá ser nacional de Estado diferente do proponente.

Artigo 37 - 1. Os membros da Comissão serão eleitos por quatro anos e só poderão ser reeleitos um vez, porém o mandato de três dos membros designados na primeira eleição expirará ao cabo de dois anos. Logo depois da referida eleição, serão determinados por sorteio, na Assembléia Geral, os nomes desses três membros.

2. Não pode fazer parte da Comissão mais de um nacional de um mesmo país.

Artigo 38 - As vagas que ocorrerem na Comissão, que não se devam à expiração normal do mandato, serão preenchidas pelo Conselho Permanente da Organização, de acordo com o que dispuser o Estatuto da Comissão.

Artigo 39 - A Comissão elaborará seu estatuto e submetê-lo-á à aprovação da Assembléia Geral e expedirá seu próprio Regulamento.

Artigo 40 - Os serviços da Secretaria da Comissão devem ser desempenhados pela unidade funcional especializada que faz parte da Secretaria Geral da Organização e deve dispor dos recursos necessários para cumprir as tarefas que lhe forem confiadas pela Comissão.

Seção 2 - Funções

Artigo 41 - A Comissão tem a função principal de promover a observância e a defesa dos direitos humanos e, no exercício de seu mandato, tem as seguintes funções e atribuições:

a) estimular a consciência dos direitos humanos nos povos da América;

b) formular recomendações aos governos dos Estados-membros, quando considerar conveniente, no sentido de que adotem medidas progressivas em prol dos direitos humanos no âmbito de suas leis internas e seus preceitos constitucionais, bem como disposições apropriadas para promover o devido respeito a esses direitos;

c) preparar estudos ou relatórios que considerar convenientes para o desempenho de suas funções;

d) solicitar aos governos dos Estados-membros que lhe proporcionem informações sobre as medidas que adotarem em matéria de direitos humanos; 
e) atender às consultas que, por meio da Secretaria Geral da Organização dos Estados Americanos, lhe formularem os Estados-membros sobre questões relacionadas com os direitos humanos e, dentro de suas possibilidades, prestar-lhes o assessoramento que lhes solicitarem; f) atuar com respeito às petições e outras comunicações, no exercício de sua autoridade, de conformidade com o disposto nos artigos 44 a 51 desta Convenção; e

g) apresentar um relatório anual à Assembléia Geral da Organização dos Estados Americanos. Artigo 42 - Os Estados-partes devem submeter à Comissão cópia dos relatórios e estudos que, em seus respectivos campos, submetem anualmente às Comissões Executivas do Conselho Interamericano Econômico e Social e do Conselho Interamericano de Educação, Ciência e Cultura, a fim de que aquela zele para que se promovam os direitos decorrentes das normas econômicas, sociais e sobre educação, ciência e cultura, constantes da Carta da Organização dos Estados Americanos, reformada pelo Protocolo de Buenos Aires.

Artigo 43 - Os Estados-partes obrigam-se a proporcionar à Comissão as informações que esta lhes solicitar sobre a maneira pela qual seu direito interno assegura a aplicação efetiva de quaisquer disposições desta Convenção.

Seção 3 - Competência

Artigo 44 - Qualquer pessoa ou grupo de pessoas, ou entidade não-governamental legalmente reconhecida em um ou mais Estados-membros da Organização, pode apresentar à Comissão petições que contenham denúncias ou queixas de violação desta Convenção por um Estadoparte.

Artigo 45 - 1. Todo Estado-parte pode, no momento do depósito do seu instrumento de ratificação desta Convenção, ou de adesão a ela, ou em qualquer momento posterior, declarar que reconhece a competência da Comissão para receber e examinar as comunicações em que um Estado-parte alegue haver outro Estado-parte incorrido em violações dos direitos humanos estabelecidos nesta Convenção.

2. As comunicações feitas em virtude deste artigo só podem ser admitidas e examinadas se forem apresentadas por um Estado-parte que haja feito uma declaração pela qual reconheça a referida competência da Comissão. A Comissão não admitirá nenhuma comunicação contra um Estado-parte que não haja feito tal declaração.

3. As declarações sobre reconhecimento de competência podem ser feitas para que esta vigore por tempo indefinido, por período determinado ou para casos específicos.

4. As declarações serão depositadas na Secretaria Geral da Organização dos Estados Americanos, a qual encaminhará cópia das mesmas aos Estados-membros da referida Organização. 
Artigo 46 - Para que uma petição ou comunicação apresentada de acordo com os artigos 44 ou 45 seja admitida pela Comissão, será necessário:

a) que hajam sido interpostos e esgotados os recursos da jurisdição interna, de acordo com os princípios de Direito Internacional geralmente reconhecidos;

b) que seja apresentada dentro do prazo de seis meses, a partir da data em que o presumido prejudicado em seus direitos tenha sido notificado da decisão definitiva;

c) que a matéria da petição ou comunicação não esteja pendente de outro processo de solução internacional; e

d) que, no caso do artigo 44, a petição contenha o nome, a nacionalidade, a profissão, o domicílio e a assinatura da pessoa ou pessoas ou do representante legal da entidade que submeter a petição.

2. As disposições das alíneas "a" e "b" do inciso 1 deste artigo não se aplicarão quando:

a) não existir, na legislação interna do Estado de que se tratar, o devido processo legal para a proteção do direito ou direitos que se alegue tenham sido violados;

b) não se houver permitido ao presumido prejudicado em seus direitos o acesso aos recursos da jurisdição interna, ou houver sido ele impedido de esgotá-los; e

c) houver demora injustificada na decisão sobre os mencionados recursos.

Artigo 47 - A Comissão declarará inadmissível toda petição ou comunicação apresentada de acordo com os artigos 44 ou 45 quando:

a) não preencher algum dos requisitos estabelecidos no artigo 46;

b) não expuser fatos que caracterizem violação dos direitos garantidos por esta Convenção;

c) pela exposição do próprio peticionário ou do Estado, for manifestamente infundada a petição ou comunicação ou for evidente sua total improcedência; ou

d) for substancialmente reprodução de petição ou comunicação anterior, já examinada pela Comissão ou por outro organismo internacional.

Seção 4 - Processo

Artigo 48 - 1. A Comissão, ao receber uma petição ou comunicação na qual se alegue a violação de qualquer dos direitos consagrados nesta Convenção, procederá da seguinte maneira:

a) se reconhecer a admissibilidade da petição ou comunicação, solicitará informações ao Governo do Estado ao qual pertença a autoridade apontada como responsável pela violação alegada e transcreverá as partes pertinentes da petição ou comunicação. As referidas informações devem ser enviadas dentro de um prazo razoável, fixado pela Comissão ao considerar as circunstâncias de cada caso; 
b) recebidas as informações, ou transcorrido o prazo fixado sem que sejam elas recebidas, verificará se existem ou subsistem os motivos da petição ou comunicação. No caso de não existirem ou não subsistirem, mandará arquivar o expediente;

c) poderá também declarar a inadmissibilidade ou a improcedência da petição ou comunicação, com base em informação ou prova supervenientes;

d) se o expediente não houver sido arquivado, e com o fim de comprovar os fatos, a Comissão procederá, com conhecimento das partes, a um exame do assunto exposto na petição ou comunicação. Se for necessário e conveniente, a Comissão procederá a uma investigação para cuja eficaz realização solicitará, e os Estados interessados the proporcionarão, todas as facilidades necessárias;

e) poderá pedir aos Estados interessados qualquer informação pertinente e receberá, se isso for solicitado, as exposições verbais ou escritas que apresentarem os interessados; e

f) pôr-se-á à disposição das partes interessadas, a fim de chegar a uma solução amistosa do assunto, fundada no respeito aos direitos reconhecidos nesta Convenção.

2. Entretanto, em casos graves e urgentes, pode ser realizada uma investigação, mediante prévio consentimento do Estado em cujo território se alegue houver sido cometida a violação, tão somente com a apresentação de uma petição ou comunicação que reúna todos os requisitos formais de admissibilidade.

Artigo 49 - Se se houver chegado a uma solução amistosa de acordo com as disposições do inciso 1, "f", do artigo 48, a Comissão redigirá um relatório que será encaminhado ao peticionário e aos Estados-partes nesta Convenção e posteriormente transmitido, para sua publicação, ao Secretário Geral da Organização dos Estados Americanos. O referido relatório conterá uma breve exposição dos fatos e da solução alcançada. Se qualquer das partes no caso o solicitar, ser-lhe-á proporcionada a mais ampla informação possível.

Artigo 50 - 1. Se não se chegar a uma solução, e dentro do prazo que for fixado pelo Estatuto da Comissão, esta redigirá um relatório no qual exporá os fatos e suas conclusões. Se o relatório não representar, no todo ou em parte, o acordo unânime dos membros da Comissão, qualquer deles poderá agregar ao referido relatório seu voto em separado. Também se agregarão ao relatório as exposições verbais ou escritas que houverem sido feitas pelos interessados em virtude do inciso 1, "e", do artigo 48.

2. O relatório será encaminhado aos Estados interessados, aos quais não será facultado publicá-lo.

3. Ao encaminhar o relatório, a Comissão pode formular as proposições e recomendações que julgar adequadas. 
Artigo 51 - 1. Se no prazo de três meses, a partir da remessa aos Estados interessados do relatório da Comissão, o assunto não houver sido solucionado ou submetido à decisão da Corte pela Comissão ou pelo Estado interessado, aceitando sua competência, a Comissão poderá emitir, pelo voto da maioria absoluta dos seus membros, sua opinião e conclusões sobre a questão submetida à sua consideração.

2. A Comissão fará as recomendações pertinentes e fixará um prazo dentro do qual o Estado deve tomar as medidas que lhe competir para remediar a situação examinada.

3. Transcorrido o prazo fixado, a Comissão decidirá, pelo voto da maioria absoluta dos seus membros, se o Estado tomou ou não as medidas adequadas e se publica ou não seu relatório.

\section{Capítulo VIII - CORTE INTERAMERICANA DE DIREITOS HUMANOS}

Seção 1 - Organização

Artigo 52 - 1. A Corte compor-se-á de sete juízes, nacionais dos Estados-membros da Organização, eleitos a título pessoal dentre juristas da mais alta autoridade moral, de reconhecida competência em matéria de direitos humanos, que reúnam as condições requeridas para o exercício das mais elevadas funções judiciais, de acordo com a lei do Estado do qual sejam nacionais, ou do Estado que os propuser como candidatos.

2. Não deve haver dois juízes da mesma nacionalidade.

Artigo 53 - 1. Os juízes da Corte serão eleitos, em votação secreta e pelo voto da maioria absoluta dos Estados-partes na Convenção, na Assembléia Geral da Organização, a partir de uma lista de candidatos propostos pelos mesmos Estados.

2. Cada um dos Estados-partes pode propor até três candidatos, nacionais do Estado que os propuser ou de qualquer outro Estado-membro da Organização dos Estados Americanos. Quando se propuser um lista de três candidatos, pelo menos um deles deverá ser nacional do Estado diferente do proponente.

Artigo 54 - 1. Os juízes da Corte serão eleitos por um período de seis anos e só poderão ser reeleitos uma vez. O mandato de três dos juízes designados na primeira eleição expirará ao cabo de três anos. Imediatamente depois da referida eleição, determinar-se-ão por sorteio, na Assembléia Geral, os nomes desse três juízes.

2. O juiz eleito para substituir outro, cujo mandato não haja expirado, completará o período deste.

3. Os juízes permanecerão em suas funções até o término dos seus mandatos. Entretanto, continuarão funcionando nos casos de que já houverem tomado conhecimento e que se encontrem em fase de sentença e, para tais efeitos, não serão substituídos pelos novos juízes eleitos. 
Artigo 55 - 1. O juiz, que for nacional de algum dos Estados-partes em caso submetido à Corte, conservará o seu direito de conhecer do mesmo.

2. Se um dos juízes chamados a conhecer do caso for de nacionalidade de um dos Estadospartes, outro Estado-parte no caso poderá designar uma pessoa de sua escolha para integrar a Corte, na qualidade de juiz ad hoc.

3. Se, dentre os juízes chamados a conhecer do caso, nenhum for da nacionalidade dos Estados-partes, cada um destes poderá designar um juiz ad hoc.

4. O juiz ad hoc deve reunir os requisitos indicados no artigo 52.

5. Se vários Estados-partes na Convenção tiverem o mesmo interesse no caso, serão considerados como uma só parte, para os fins das disposições anteriores. Em caso de dúvida, a Corte decidirá.

Artigo 56 - O quorum para as deliberações da Corte é constituído por cinco juízes.

Artigo 57 - A Comissão comparecerá em todos os casos perante a Corte.

Artigo 58 - 1. A Corte terá sua sede no lugar que for determinado, na Assembléia Geral da Organização, pelos Estados-partes na Convenção, mas poderá realizar reuniões no território de qualquer Estado-membro da Organização dos Estados Americanos em que considerar conveniente, pela maioria dos seus membros e mediante prévia aquiescência do Estado respectivo. Os Estados-partes na Convenção podem, na Assembléia Geral, por dois terços dos seus votos, mudar a sede da Corte.

2. A Corte designará seu Secretário.

3. O Secretário residirá na sede da Corte e deverá assistir às reuniões que ela realizar fora da mesma.

Artigo 59 - A Secretaria da Corte será por esta estabelecida e funcionará sob a direção do Secretário Geral da Organização em tudo o que não for incompatível com a independência da Corte. Seus funcionários serão nomeados pelo Secretário Geral da Organização, em consulta com o Secretário da Corte.

Artigo 60 - A Corte elaborará seu Estatuto e submetê-lo-á à aprovação da Assembléia Geral e expedirá seu Regimento.

Seção 2 - Competência e funções

Artigo 61 - 1. Somente os Estados-partes e a Comissão têm direito de submeter um caso à decisão da Corte.

2. Para que a Corte possa conhecer de qualquer caso, é necessário que sejam esgotados os processos previstos nos artigos 48 a 50. 
Artigo 62 - 1. Todo Estado-parte pode, no momento do depósito do seu instrumento de ratificação desta Convenção ou de adesão a ela, ou em qualquer momento posterior, declarar que reconhece como obrigatória, de pleno direito e sem convenção especial, a competência da Corte em todos os casos relativos à interpretação ou aplicação desta Convenção.

2. A declaração pode ser feita incondicionalmente, ou sob condição de reciprocidade, por prazo determinado ou para casos específicos. Deverá ser apresentada ao Secretário Geral da Organização, que encaminhará cópias da mesma a outros Estados-membros da Organização e ao Secretário da Corte.

3. A Corte tem competência para conhecer de qualquer caso, relativo à interpretação e aplicação das disposições desta Convenção, que lhe seja submetido, desde que os Estadospartes no caso tenham reconhecido ou reconheçam a referida competência, seja por declaração especial, como prevêem os incisos anteriores, seja por convenção especial.

Artigo 63 - 1. Quando decidir que houve violação de um direito ou liberdade protegidos nesta Convenção, a Corte determinará que se assegure ao prejudicado o gozo do seu direito ou liberdade violados. Determinará também, se isso for procedente, que sejam reparadas as consequências da medida ou situação que haja configurado a violação desses direitos, bem como o pagamento de indenização justa à parte lesada.

2. Em casos de extrema gravidade e urgência, e quando se fizer necessário evitar danos irreparáveis às pessoas, a Corte, nos assuntos de que estiver conhecendo, poderá tomar as medidas provisórias que considerar pertinentes. Se se tratar de assuntos que ainda não estiverem submetidos ao seu conhecimento, poderá atuar a pedido da Comissão.

Artigo 64 - 1. Os Estados-membros da Organização poderão consultar a Corte sobre a interpretação desta Convenção ou de outros tratados concernentes à proteção dos direitos humanos nos Estados americanos. Também poderão consultá-la, no que lhes compete, os órgãos enumerados no capítulo $\mathrm{X}$ da Carta da Organização dos Estados Americanos, reformada pelo Protocolo de Buenos Aires.

2. A Corte, a pedido de um Estado-membro da Organização, poderá emitir pareceres sobre a compatibilidade entre qualquer de suas leis internas e os mencionados instrumentos internacionais.

Artigo 65 - A Corte submeterá à consideração da Assembléia Geral da Organização, em cada período ordinário de sessões, um relatório sobre as suas atividades no ano anterior. De maneira especial, e com as recomendações pertinentes, indicará os casos em que um Estado não tenha dado cumprimento a suas sentenças.

Seção 3 - Processo 
Artigo 66 - 1. A sentença da Corte deve ser fundamentada.

2. Se a sentença não expressar no todo ou em parte a opinião unânime dos juízes, qualquer deles terá direito a que se agregue à sentença o seu voto dissidente ou individual.

Artigo 67 - A sentença da Corte será definitiva e inapelável. Em caso de divergência sobre o sentido ou alcance da sentença, a Corte interpretá-la-á, a pedido de qualquer das partes, desde que o pedido seja apresentado dentro de noventa dias a partir da data da notificação da sentença.

Artigo 68 - 1. Os Estados-partes na Convenção comprometem-se a cumprir a decisão da Corte em todo caso em que forem partes.

2. A parte da sentença que determinar indenização compensatória poderá ser executada no país respectivo pelo processo interno vigente para a execução de sentenças contra o Estado.

Artigo 69 - A sentença da Corte deve ser notificada às partes no caso e transmitida aos Estados-partes na Convenção.

\section{Capítulo IX - DISPOSIÇÕES COMUNS}

Artigo 70 - 1. Os juízes da Corte e os membros da Comissão gozam, desde o momento da eleição e enquanto durar o seu mandato, das imunidades reconhecidas aos agentes diplomáticos pelo Direito Internacional. Durante o exercício dos seus cargos gozam, além disso, dos privilégios diplomáticos necessários para o desempenho de suas funções.

2. Não se poderá exigir responsabilidade em tempo algum dos juízes da Corte, nem dos membros da Comissão, por votos e opiniões emitidos no exercício de suas funções.

Artigo 71 - Os cargos de juiz da Corte ou de membro da Comissão são incompatíveis com outras atividades que possam afetar sua independência ou imparcialidade, conforme o que for determinado nos respectivos Estatutos.

Artigo 72 - Os juízes da Corte e os membros da Comissão perceberão honorários e despesas de viagem na forma e nas condições que determinarem os seus Estatutos, levando em conta a importância e independência de suas funções. Tais honorários e despesas de viagem serão fixados no orçamento-programa da Organização dos Estados Americanos, no qual devem ser incluídas, além disso, as despesas da Corte e da sua Secretaria. Para tais efeitos, a Corte elaborará o seu próprio projeto de orçamento e submetê-lo-á à aprovação da Assembléia Geral, por intermédio da Secretaria Geral. Esta última não poderá nele introduzir modificações.

Artigo 73 - Somente por solicitação da Comissão ou da Corte, conforme o caso, cabe à Assembléia Geral da Organização resolver sobre as sanções aplicáveis aos membros da Comissão ou aos juízes da Corte que incorrerem nos casos previstos nos respectivos 
Estatutos. Para expedir uma resolução, será necessária maioria de dois terços dos votos dos Estados-membros da Organização, no caso dos membros da Comissão; e, além disso, de dois terços dos votos dos Estados-partes na Convenção, se se tratar dos juízes da Corte.

\section{PARTE III - DISPOSIÇÕES GERAIS E TRANSITÓRIAS}

Capítulo X - ASSINATURA, RATIFICAÇÃO, RESERVA, EMENDA, PROTOCOLO E DENÚNCIA

Artigo 74 - 1. Esta Convenção está aberta à assinatura e à ratificação de todos os Estadosmembros da Organização dos Estados Americanos.

2. A ratificação desta Convenção ou a adesão a ela efetuar-se-á mediante depósito de um instrumento de ratificação ou adesão na Secretaria Geral da Organização dos Estados Americanos. Esta Convenção entrará em vigor logo que onze Estados houverem depositado os seus respectivos instrumentos de ratificação ou de adesão. Com referência a qualquer outro Estado que a ratificar ou que a ela aderir ulteriormente, a Convenção entrará em vigor na data do depósito do seu instrumento de ratificação ou adesão.

3. O Secretário Geral comunicará todos os Estados-membros da Organização sobre a entrada em vigor da Convenção.

Artigo 75 - Esta Convenção só pode ser objeto de reservas em conformidade com as disposições da Convenção de Viena sobre o Direito dos Tratados, assinada em 23 de maio de 1969.

Artigo 76 - 1. Qualquer Estado-parte, diretamente, e a Comissão e a Corte, por intermédio do Secretário Geral, podem submeter à Assembléia Geral, para o que julgarem conveniente, proposta de emendas a esta Convenção.

2. Tais emendas entrarão em vigor para os Estados que as ratificarem, na data em que houver sido depositado o respectivo instrumento de ratificação, por dois terços dos Estados-partes nesta Convenção. Quanto aos outros Estados-partes, entrarão em vigor na data em que eles depositarem os seus respectivos instrumentos de ratificação.

Artigo 77 - 1. De acordo com a faculdade estabelecida no artigo 31, qualquer Estado-parte e a Comissão podem submeter à consideração dos Estados-partes reunidos por ocasião da Assembléia Geral projetos de Protocolos adicionais a esta Convenção, com a finalidade de incluir progressivamente, no regime de proteção da mesma, outros direitos e liberdades.

2. Cada Protocolo deve estabelecer as modalidades de sua entrada em vigor e será aplicado somente entre os Estados-partes no mesmo. 
Artigo 78 - 1. Os Estados-partes poderão denunciar esta Convenção depois de expirado o prazo de cinco anos, a partir da data em vigor da mesma e mediante aviso prévio de um ano, notificando o Secretário Geral da Organização, o qual deve informar as outras partes.

2. Tal denúncia não terá o efeito de desligar o Estado-parte interessado das obrigações contidas nesta Convenção, no que diz respeito a qualquer ato que, podendo constituir violação dessas obrigações, houver sido cometido por ele anteriormente à data na qual a denúncia produzir efeito.

Capítulo XI -

\section{DISPOSIÇÕES TRANSITÓRIAS}

Seção 1 - Comissão Interamericana de Direitos Humanos

Artigo 79 - Ao entrar em vigor esta Convenção, o Secretário Geral pedirá por escrito a cada Estado-membro da Organização que apresente, dentro de um prazo de noventa dias, seus candidatos a membro da Comissão Interamericana de Direitos Humanos. O Secretário Geral preparará uma lista por ordem alfabética dos candidatos apresentados e a encaminhará aos Estados-membros da Organização, pelo menos trinta dias antes da Assembléia Geral seguinte. Artigo 80 - A eleição dos membros da Comissão far-se-á dentre os candidatos que figurem na lista a que se refere o artigo 79, por votação secreta da Assembléia Geral, e serão declarados eleitos os candidatos que obtiverem maior número de votos e a maioria absoluta dos votos dos representantes dos Estados-membros. Se, para eleger todos os membros da Comissão, for necessário realizar várias votações, serão eliminados sucessivamente, na forma que for determinada pela Assembléia Geral, os candidatos que receberem maior número de votos.

Seção 2 - Corte Interamericana de Direitos Humanos

Artigo 81 - Ao entrar em vigor esta Convenção, o Secretário Geral pedirá a cada Estado-parte que apresente, dentro de um prazo de noventa dias, seus candidatos a juiz da Corte Interamericana de Direitos Humanos. O Secretário Geral preparará uma lista por ordem alfabética dos candidatos apresentados e a encaminhará aos Estados-partes pelo menos trinta dias antes da Assembléia Geral seguinte.

Artigo 82 - A eleição dos juízes da Corte far-se-á dentre os candidatos que figurem na lista a que se refere o artigo 81, por votação secreta dos Estados-partes, na Assembléia Geral, e serão declarados eleitos os candidatos que obtiverem o maior número de votos e a maioria absoluta dos votos dos representantes dos Estados-partes. Se, para eleger todos os juízes da Corte, for necessário realizar várias votações, serão eliminados sucessivamente, na forma que for determinada pelos Estados-partes, os candidatos que receberem menor número de votos. 


\section{Declaração sobre a Proteção de Todas as Pessoas Contra os Desaparecimentos Forçados}

Proclamada pela Assembléia Geral das Nações Unidas na sua resolução 47/133, de 18 de Dezembro de 1992.

A Assembléia Geral,

Considerando que, em conformidade com os princípios proclamados na Carta das Nações Unidas e em outros instrumentos internacionais, o reconhecimento da dignidade inerente e dos direitos iguais e inalienáveis de todos os membros da família humana constitui o fundamento da liberdade, da justiça e da paz no mundo,

Tendo presente a obrigação dos Estados em virtude da Carta, em particular do seu artigo 55. , de promover o respeito universal e efetivo dos direitos humanos e das liberdades fundamentais,

Profundamente preocupada por constatar que em muitos países, freqüentemente de forma persistente, ocorrem desaparecimentos forçados, no sentido de que as pessoas são presas, detidas ou raptadas contra a sua vontade ou de outra forma privadas de liberdade por agentes governamentais de qualquer ramo ou nível, que de seguida se recusam a revelar o destino ou paradeiro das pessoas em causa ou se recusam a reconhecer a privação de liberdade, assim subtraindo tais pessoas à proteção da lei,

Considerando que os desaparecimentos forçados atentam contra os mais profundos valores de qualquer sociedade empenhada em respeitar o Estado de Direito, os direitos humanos e as liberdades fundamentais, e que a prática sistemática de tais atos configura um crime contra a Humanidade,

Recordando a sua resolução 33/173, de 22 de Dezembro de 1978, na qual manifestou preocupação pelos relatos de desaparecimentos forçados ou involuntários oriundos de diversas partes do mundo, bem como pela angústia e pela dor provocadas por esses desaparecimentos, e instou os Governos a fazer incorrer as autoridades encarregadas de aplicar a lei e as forças de segurança em responsabilidade jurídica pelos excessos que possam conduzir a desaparecimentos forçados ou involuntários de seres humanos,

Recordando também a proteção conferida às vítimas de conflitos armados pelas Convenções de Genebra de 12 de Agosto de 1949 e seus Protocolos Adicionais de 1977,

Tendo em conta em particular os pertinentes artigos da Declaração Universal dos Direitos do Homem e do Pacto Internacional sobre os Direitos Civis e Políticos, que protegem o direito à 
vida, o direito à liberdade e à segurança da pessoa, o direito a não ser sujeito à tortura e o direito ao reconhecimento da personalidade jurídica,

Tendo em conta também a Convenção contra a Tortura e Outras Penas ou Tratamentos Cruéis, Desumanos ou Degradantes, que estabelece que os Estados partes deverão tomar medidas eficazes para prevenir e punir os atos de tortura,

Tendo presentes o Código de Conduta para os Funcionários Responsáveis pela Aplicação da Lei, os Princípios Básicos sobre a Utilização da Força e de Armas de Fogo pelos Funcionários Responsáveis pela Aplicação da Lei, a Declaração dos Princípios Básicos de Justiça Relativa às Vítimas da Criminalidade e de Abuso de Poder e as Regras Mínimas para o Tratamento de Reclusos,

Afirmando que, para prevenir os desaparecimentos forçados, é necessário garantir a estrita observância do Conjunto de Princípios para a Proteção de Todas as Pessoas Sujeitas a Qualquer Forma de Detenção ou Prisão contidos em anexo à sua resolução 43/173, de 9 de Dezembro de 1988, e dos Princípios sobre a Prevenção Eficaz e Investigação das Execuções Extrajudiciais, Arbitrárias ou Sumárias, constantes do anexo à resolução 1989/65 do Conselho Econômico e Social, de 24 de Maio de 1989 e aprovados pela Assembléia Geral na sua resolução 44/162, de 15 de Dezembro de 1989,

Tendo presente que, embora os atos que configuram um desaparecimento forçado constituam uma violação das proibições constantes dos instrumentos internacionais acima mencionados, continua, no entanto, a ser importante elaborar um instrumento que caracterize todos os atos de desaparecimento forçado de pessoas como infrações muito graves e consagre normas concebidas para punir e prevenir tais crimes,

1. Proclama a presente Declaração sobre a Proteção de Todas as Pessoas contra os Desaparecimentos Forçados como um conjunto de princípios aplicáveis a todos os Estados;

2. Insta a que sejam feitos todos os esforços para que a Declaração se torne amplamente conhecida e respeitada:

Artigo 1. ${ }^{\circ}$

1. Qualquer ato de desaparecimento forçado constitui um atentado à dignidade humana. É condenado enquanto uma negação dos objetivos das Nações Unidas e uma grave e flagrante violação dos direitos humanos e liberdades fundamentais proclamados na Declaração Universal dos Direitos do Homem e reafirmados e desenvolvidos noutros instrumentos internacionais nesta matéria.

2. Todo o ato de desaparecimento forçado subtrai as pessoas que a ele são sujeitas à proteção da lei e provoca grandes sofrimentos a essas pessoas e às suas famílias. Constitui uma 
violação das normas de direito internacional que garantem, nomeadamente, o direito ao reconhecimento da personalidade jurídica, o direito à liberdade e segurança pessoal e o direito a não ser sujeito à tortura ou a outras penas ou tratamentos cruéis, desumanos ou degradantes. Também viola ou constitui uma grave ameaça ao direito à vida.

Artigo 2.

1. Nenhum Estado deverá cometer, permitir ou tolerar os desaparecimentos forçados.

2. Os Estados deverão agir aos níveis nacional e regional e em cooperação com as Nações Unidas para contribuir por todos os meios para a prevenção e erradicação dos desaparecimentos forçados.

Artigo $3 .^{\circ}$

Todos os Estados deverão adotar medidas eficazes nos planos legislativo, administrativo, judicial ou outros para prevenir e erradicar os atos conducentes a desaparecimentos forçados em qualquer território sujeito à sua jurisdição.

Artigo 4.

1. Todos os atos conducentes a desaparecimentos forçados serão considerados infrações nos termos da lei penal e puníveis com penas adequadas que tenham em conta a sua extrema gravidade.

2. A lei nacional poderá prever circunstâncias atenuantes para as pessoas que, tendo participado em desaparecimentos forçados, contribuam para a reaparição da vítima com vida ou voluntariamente forneçam informações que possam contribuir para o esclarecimento dos casos de desaparecimento forçado.

Artigo 5..$^{\circ}$

Para além das sanções penais aplicáveis, os desaparecimentos forçados fazem incorrer os seus autores e o Estado ou autoridades públicas que organizem, consintam ou tolerem tais desaparecimentos, em responsabilidade civil, sem prejuízo da responsabilidade internacional do Estado em causa em conformidade com os princípios de direito internacional.

Artigo 6.

1. Nenhuma ordem ou instrução emanada de qualquer autoridade pública, civil, militar ou de outra natureza, poderá ser invocada para justificar um desaparecimento forçado. Qualquer pessoa que receba tal ordem ou instrução terá o direito e o dever de não lhe obedecer.

2. Todos os Estados deverão garantir que as ordens ou instruções que ordenem, autorizem ou encorajem qualquer desaparecimento forçado sejam proibidas.

3. Na formação dos funcionários responsáveis pela aplicação da lei dever-se-ão destacar as disposições do primeiro e segundo parágrafos do presente artigo. 
Artigo 7.

Nenhumas circunstâncias, sejam de que natureza forem, quer se trate de ameaça de guerra, estado de guerra, instabilidade política interna ou qualquer outra situação de emergência pública, poderão ser invocadas para justificar um desaparecimento forçado.

Artigo 8.

1. Nenhum Estado deverá expulsar, repatriar ou extraditar uma pessoa para outro Estado caso existam motivos sérios para crer que aí a pessoa possa estar em risco de ser vítima de um desaparecimento forçado.

2. A fim de determinar se esses motivos existem ou não, as autoridades competentes deverão ter em conta todas as considerações relevantes, nomeadamente e se for o caso, a existência no Estado em causa de um padrão constante de violações graves, flagrantes e sistemáticas de direitos humanos.

Artigo 9. ${ }^{\circ}$

1. É necessário garantir o direito a um recurso judicial rápido e eficaz, enquanto meio de determinar o paradeiro ou estado de saúde das pessoas privadas de liberdade e/ou de identificar a autoridade que ordenou ou levou a cabo a privação de liberdade, a fim de prevenir a ocorrência de desaparecimentos forçados em todas as circunstâncias, nomeadamente as referidas no artigo $7 .^{\circ}$, supra.

2. No âmbito desses processos de recurso, as autoridades nacionais competentes deverão ter acesso a todos os locais onde se encontrem pessoas privadas de liberdade e a todas as áreas desses locais, bem como a qualquer local onde existam razões para crer que essas pessoas possam ser encontradas.

3. Qualquer outra autoridade competente nos termos da lei interna do Estado ou de qualquer instrumento jurídico internacional do qual o Estado seja parte poderá também ter acesso a esses locais.

Artigo $10 .^{\circ}$

1. Toda a pessoa privada de liberdade deverá ser mantida num local de detenção oficialmente reconhecido e, em conformidade com a lei nacional, comparecer perante uma autoridade judicial no mais curto espaço de tempo após a detenção.

2. Informação exata sobre a detenção das pessoas em causa e seu local ou locais de detenção, incluindo locais para onde sejam transferidas, deverá ser prontamente fornecida aos membros da sua família, ao seu advogado e a qualquer outra pessoa com um interesse legítimo em tal informação, a menos que as pessoas privadas de liberdade manifestem o desejo em contrário. 
3. Todos os locais de detenção deverão manter registros oficiais atualizados de todas as pessoas privadas de liberdade. Para além disso, cada Estado deverá adotar medidas a fim de manter registros centralizados similares. A informação constante dos registros deverá ser posta à disposição das pessoas referidas no parágrafo anterior, de qualquer autoridade judicial ou outra autoridade nacional competente e independente e de qualquer outra autoridade competente nos termos da lei do Estado ou de qualquer instrumento jurídico internacional do qual o Estado em causa seja parte, que procure determinar o paradeiro da pessoa detida.

Artigo $111^{\circ}$

Todas as pessoas privadas de liberdade deverão ser libertadas de forma a permitir verificar com certeza que foram de fato postas em liberdade e, além do mais, que foram libertadas em condições que garantam a sua integridade física e capacidade de exercer plenamente os seus direitos.

Artigo 12.

1. Todos os Estados deverão adotar normas internas a fim de designar os funcionários autorizados a ordenar a privação de liberdade, definir em que condições essas ordens podem ser dadas e prever sanções para os funcionários que, sem justificação legal, se recusem a prestar informação sobre qualquer detenção.

2. Todos os Estados deverão, de forma semelhante, garantir uma supervisão rigorosa, nomeadamente através de uma cadeia hierárquica bem definida, de todos os funcionários responsáveis pela aplicação da lei cujas funções incluam a captura, detenção, guarda, transferência e prisão de pessoas, bem como de todos os outros funcionários autorizados por lei a utilizar a força ou armas de fogo.

Artigo $13 .^{\circ}$

1. Todos os Estados deverão garantir a todas as pessoas que tenham conhecimento ou possam invocar um interesse legítimo e aleguem que uma pessoa foi vítima de um desaparecimento forçado, o direito de denunciar os fatos perante uma autoridade do Estado e a que essa denúncia seja pronta, exaustiva e imparcialmente investigada pela autoridade em causa. Sempre que existam motivos razoáveis para acreditar que ocorreu um desaparecimento forçado, o Estado deverá comunicar os fatos a essa autoridade para que seja instaurado inquérito, mesmo na ausência de uma denúncia formal. Não deverá ser tomada qualquer medida a fim de limitar ou colocar obstáculos a esse inquérito.

2. Todos os Estados deverão garantir que a autoridade competente disponha das competências e recursos necessários para conduzir as investigações de forma eficaz, nomeadamente poderes 
para exigir a comparecimento de testemunhas e a apresentação dos documentos pertinentes e para visitar imediatamente os locais em causa.

3. Deverão ser adotadas medidas para garantir que todas as pessoas envolvidas na investigação, nomeadamente o denunciante, o advogado, as testemunhas e os agentes que conduzem o inquérito, sejam protegidos contra quaisquer maus tratos, atos de intimidação ou represálias.

4. Os resultados das investigações deverão ser comunicados a todas as pessoas interessadas, a pedido destas, a menos que isso prejudique as investigações em curso.

5. Deverão ser adotadas medidas para garantir que qualquer forma de maus tratos, intimidação ou represálias ou qualquer outra forma de interferência quando da apresentação da denúncia ou no decorrer do processo de investigação seja adequadamente punida.

6. Uma investigação, em conformidade com os procedimentos acima descritos, dever-se-á manter em curso enquanto o destino da vítima do desaparecimento forçado não for esclarecido.

Artigo $14 .^{\circ}$

Todos os presumíveis autores de atos conducentes a um desaparecimento forçado perpetrado num determinado Estado deverão, uma vez que os fatos apurados mediante uma investigação oficial assim o justifiquem, comparecer perante as autoridades civis desse Estado para fins de instauração de ação penal e julgamento, a menos que tenham sido extraditados para outro Estado que deseje exercer jurisdição em conformidade com os pertinentes acordos internacionais em vigor. Todos os Estados deverão adotar todas as medidas lícitas e apropriadas ao seu dispor para levar a responder perante a justiça todos os presumíveis autores de atos conducentes a desaparecimentos forçados que se encontrem sob a sua jurisdição ou controlo.

Artigo $15 .^{\circ}$

O fato de existirem motivos razoáveis para acreditar que uma pessoa participou em atos de extrema gravidade como os referidos no artigo $4 .^{\circ}$, n. $^{\circ}$ 1, supra, independentemente dos motivos porque o fez, deverá ser tomado em conta pelas autoridades competentes do Estado ao decidirem sobre um pedido de asilo.

Artigo $16^{\circ}$

1. Os presumíveis autores de qualquer dos atos referidos no artigo $4 .^{\circ}, \mathrm{n}^{\circ} 1$, supra, deverão ser suspensos do exercício de quaisquer funções oficiais durante a investigação referida no artigo $13 .^{\circ}$, supra. 
2. Deverão ser julgados apenas pelos competentes tribunais comuns do Estado e não por quaisquer tribunais especiais, em particular tribunais militares.

3. Não serão reconhecidos quaisquer privilégios, imunidades ou dispensas especiais no âmbito de tais processos, sem prejuízo das disposições enunciadas na Convenção de Viena sobre Relações Diplomáticas.

4. Aos presumíveis autores de tais atos deverá ser garantido, em todas as fases da investigação e eventual processo penal e julgamento, um tratamento eqüitativo, em conformidade com as pertinentes disposições da Declaração Universal dos Direitos do Homem e de outros pertinentes acordos internacionais em vigor.

Artigo $17 .^{\circ}$

1. Os atos que consubstanciam um desaparecimento forçado deverão ser considerados um crime continuado enquanto os seus autores continuarem a esconder o destino e o paradeiro das pessoas desaparecidas e estes fatos não ficarem esclarecidos.

2. Quando os meios de recurso previstos no artigo $2 .^{\circ}$ do Pacto Internacional sobre os Direitos Civis e Políticos deixarem de ser eficazes, a contagem do prazo de prescrição aplicável aos atos conducentes a um desaparecimento forçado será suspensa até que os meios de recurso sejam restabelecidos.

3. O prazo de prescrição aplicável aos atos conducentes a um desaparecimento forçado, quando exista, deverá ser longo e proporcional à extrema gravidade da infração.

Artigo $18 .^{\circ}$

1. Os autores ou presumíveis autores das infrações referidas no artigo $4 .^{\circ}$, n. $^{\circ} 1$, supra, não deverão beneficiar de qualquer lei especial de anistia ou medida semelhante que possa ter como efeito ilibá-los de qualquer procedimento ou sanção penal.

2. No exercício do direito de solicitar o indulto, dever-se-á ter em conta a extrema gravidade dos atos conducentes a um desaparecimento forçado.

Artigo $199^{\circ}$

As vítimas de desaparecimentos forçados e suas famílias deverão obter reparação e terão direito a uma adequada compensação, nomeadamente a meios que permitam uma reabilitação tão completa quanto possível. Na eventualidade de morte da vítima em resultado de um desaparecimento forçado, a sua família deverá também ter direito a compensação.

Artigo $20 .^{\circ}$

1. Os Estados deverão prevenir e erradicar o rapto de crianças filhas de pais vítimas de desaparecimentos forçados e de crianças nascidas durante o período de desaparecimento 
forçado das suas mães e deverão empreender esforços no sentido de procurar e identificar essas crianças e enviá-las de volta ao seio das suas famílias de origem.

2. Considerando a necessidade de proteger o interesse superior das crianças referidas no parágrafo anterior, deverá ser possível, nos Estados que reconhecem o sistema de adoção, rever o processo de adoção dessas crianças e, em particular, anular qualquer adoção que tenha tido origem num desaparecimento forçado. Tal adoção deverá, no entanto, continuar a produzir efeitos caso seja dado consentimento, no momento da revisão, pelos familiares mais próximos da criança.

3. O rapto de crianças filhas de pais vítimas de desaparecimentos forçados ou de crianças nascidas durante o período de desaparecimento das suas mães, bem como o ato de alterar ou suprimir documentos comprovativos da sua verdadeira identidade, deverão ser consideradas infrações extremamente graves e punidas como tal.

4. Para estes fins, os Estados deverão, se apropriado, celebrar acordos bilaterais e multilaterais.

Artigo $21 .^{\circ}$

As disposições da presente Declaração não prejudicam as disposições enunciadas na Declaração Universal dos Direitos do Homem ou em qualquer outro instrumento internacional e não deverão ser interpretadas como uma restrição ou derrogação de qualquer dessas disposições. 


\section{Convenção Interamericana sobre o Desaparecimento Forçado de Pessoas}

\section{OS ESTADOS MEMBROS DA ORGANIZAÇÃO DOS ESTADOS AMERICANOS,}

PREOCUPADOS pelo fato de que subsiste o desaparecimento forçado de pessoas;

REAFIRMANDO que o verdadeiro sentido da solidariedade americana e da boa vizinhança só pode ser o de consolidar neste Hemisfério, no quadro das instituições democráticas, um regime de liberdade individual e de justiça social, fundado no respeito dos direitos essenciais do homem;

CONSIDERANDO que o desaparecimento forçado de pessoas constitui uma afronta à consciência do Hemisfério e uma grave ofensa de natureza hedionda à dignidade inerente à pessoa humana, em contradição com os princípios e propósitos consagrados na Carta da Organização dos Estados Americanos;

CONSIDERANDO que o desaparecimento forçado de pessoas viola múltiplos direitos essenciais da pessoa humana, de caráter irrevogável, conforme consagrados na Convenção Americana sobre Direitos Humanos, na Declaração Americana dos Direitos e Deveres do Homem e na Declaração Universal dos Direitos Humanos;

RECORDANDO que a proteção internacional dos direitos humanos é de natureza convencional coadjuvante ou complementar da que oferece o direito interno, e tem como fundamento os atributos da pessoa humana;

REAFIRMANDO que a prática sistemática do desaparecimento forçado de pessoas constitui um crime de lesa-humanidade;

ESPERANDO que esta Convenção contribua para prevenir, punir e eliminar o desaparecimento forçado de pessoas no Hemisfério e constitua uma contribuição decisiva para a proteção dos direitos humanos e para o Estado de Direito,

RESOLVEM adotar a seguinte Convenção Interamericana sobre o Desaparecimento Forçado de Pessoas:

ARTIGO I

Os Estados Partes nesta Convenção comprometem-se a: 
a) não praticar, nem permitir, nem tolerar o desaparecimento forçado de pessoas, nem mesmo em estado de emergência, exceção ou suspensão de garantias individuais;

b) punir, no âmbito de sua jurisdição, os autores, cúmplices e encobridores do delito do desaparecimento forçado de pessoas, bem como da tentativa de prática do mesmo;

c) cooperar entre si a fim de contribuir para a prevenção, punição e erradicação do desaparecimento forçado de pessoas; e

d) tomar as medidas de caráter legislativo, administrativo, judicial ou de qualquer outra natureza que sejam necessárias para cumprir os compromissos assumidos nesta Convenção.

\section{ARTIGO II}

Para os efeitos desta Convenção, entende-se por desaparecimento forçado a privação de liberdade de uma pessoa ou mais pessoas, seja de que forma for, praticada por agentes do Estado ou por pessoas ou grupos de pessoas que atuem com autorização, apoio ou consentimento do Estado, seguida de falta de informação ou da recusa a reconhecer a privação de liberdade ou a informar sobre o paradeiro da pessoa, impedindo assim o exercício dos recursos legais e das garantias processuais pertinentes.

\section{ARTIGO III}

Os Estados Partes comprometem-se a adotar, de acordo com seus procedimentos constitucionais, as medidas legislativas que forem necessárias para tipificar como delito o desaparecimento forçado de pessoas e a impor-lhe a pena apropriada que leve em conta sua extrema gravidade. Esse delito será considerado continuado ou permanente, enquanto não se estabelecer o destino ou paradeiro da vítima.

Os Estados Partes poderão estabelecer circunstâncias atenuantes para aqueles que tiverem participado de atos que constituam desaparecimento forçado, quando contribuam para o aparecimento com vida da vítima ou forneçam informações que permitam esclarecer o desaparecimento forçado de uma pessoa.

\section{ARTIGO IV}

Os atos constitutivos do desaparecimento forçado de pessoas serão considerados delitos em qualquer Estado Parte. Em conseqüência, cada Estado Parte adotará as medidas para estabelecer sua jurisdição sobre a causa nos seguintes casos: 
a) quando o desaparecimento forçado de pessoas ou qualquer de seus atos constitutivos tiverem sido perpetrados no âmbito de sua jurisdição;

b) quando o acusado for nacional desse Estado;

c) quando a vítima for nacional desse Estado e este o considerar apropriado.

Todo Estado Parte tomará também as medidas necessárias para estabelecer sua jurisdição sobre o delito descrito nesta Convenção, quando o suspeito se encontrar no seu território e o Estado não o extraditar.

Esta Convenção não faculta um Estado Parte a empreender no território de outro Estado Parte o exercício da jurisdição nem o desempenho das funções reservadas exclusivamente às autoridades da outra Parte por sua legislação interna.

\section{ARTIGO V}

O desaparecimento forçado de pessoas não será considerado delito político para os efeitos de extradição.

O desaparecimento forçado será considerado incluído entre os delitos que justificam extradição em todo tratado de extradição celebrado entre Estados Partes.

Os Estados Partes comprometem-se a incluir o delito de desaparecimento forçado como passível de extradição em todo tratado de extradição que celebrarem entre si no futuro.

Todo Estado Parte que sujeitar a extradição à existência de um tratado e receber de outro Estado Parte com o qual não tiver tratado uma solicitação de extradição poderá considerar esta Convenção como base jurídica necessária para a extradição referente ao delito de desaparecimento forçado.

Os Estados Partes que não subordinarem a extradição à existência de um tratado reconhecerão esse delito como passível de extradição, sujeita às condições exigidas pelo direito do Estado requerido.

A extradição estará sujeita às disposições previstas na Constituição e demais leis do Estado requerido.

\section{ARTIGO VI}

Quando um Estado Parte não conceder a extradição, submeterá o caso a suas autoridades competentes como se o delito tivesse sido cometido no âmbito de sua jurisdição, para fins de investigação e, quando for cabível, de ação penal, de conformidade com sua legislação 
nacional. A decisão que adotarem essas autoridades será comunicada ao Estado que tiver solicitado a extradição.

\section{ARTIGO VII}

A ação penal decorrente do desaparecimento forçado de pessoas e a pena que for imposta judicialmente ao responsável por ela não estarão sujeitas a prescrição.

No entanto, quando existir uma norma de caráter fundamental que impeça a aplicação do estipulado no parágrafo anterior, o prazo da prescrição deverá ser igual ao do delito mais grave na legislação interna do respectivo Estado Parte.

\section{ARTIGO VIII}

Não se admitirá como causa dirimente a obediência devida a ordens ou instruções superiores que disponham, autorizem ou incentivem o desaparecimento forçado. Toda pessoa que receber tais ordens tem o direito e o dever de não obedecê-las.

Os Estados Partes velarão também para que, na formação do pessoal ou dos funcionários públicos encarregados da aplicação da lei, seja ministrada a educação necessária sobre o delito de desaparecimento forçado de pessoas.

\section{ARTIGO IX}

Os suspeitos dos atos constitutivos do delito do desaparecimento forçado de pessoas só poderão ser julgados pelas jurisdições de direito comum competentes, em cada Estado, com exclusão de qualquer outra jurisdição especial, particularmente a militar.

Os atos constitutivos do desaparecimento forçado não poderão ser considerados como cometidos no exercício das funções militares.

Não serão admitidos privilégios, imunidades nem dispensas especiais nesses processos, sem prejuízo das disposições que figuram na Convenção de Viena sobre Relações Diplomáticas.

\section{ARTIGO X}

Em nenhum caso poderão ser invocadas circunstâncias excepcionais, tais como estado de guerra ou ameaça de guerra, instabilidade política interna ou qualquer outra emergência pública, para justificar o desaparecimento forçado de pessoas. Nesses casos, será mantido o direito a procedimentos ou recursos judiciais rápidos e eficazes, como meio de determinar o paradeiro das pessoas privadas de liberdade ou seu estado de saúde, ou de identificar a autoridade que ordenou a privação de liberdade ou a tomou efetiva. 
$\mathrm{Na}$ tramitação desses procedimentos ou recursos e de conformidade com o direito interno respectivo, as autoridades judiciárias competentes terão livre e imediato acesso a todo centro de detenção e a cada uma de suas dependências, bem como a todo lugar onde houver motivo para crer que se possa encontrar a pessoa desaparecida, inclusive lugares sujeitos à jurisdição militar.

\section{ARTIGO XI}

Toda pessoa privada de liberdade deve ser mantida em lugares de detenção oficialmente reconhecidos e apresentada, sem demora e de acordo com a legislação interna respectiva, à autoridade judiciária competente.

Os Estados Partes estabelecerão e manterão registros oficiais atualizados sobre seus detidos e, de conformidade com sua legislação interna, os colocarão à disposição dos familiares dos detidos, bem como dos juizes, advogados, qualquer pessoa com interesse legítimo e outras autoridades.

\section{ARTIGO XII}

Os Estados Partes prestar-se-ão cooperação recíproca na busca, identificação, localização e restituição de menores que tenham sido transportados para outro Estado ou retidos neste em conseqüência do desaparecimento forçado de seus pais, tutores ou guardiães.

\section{ARTIGO XIII}

Para os efeitos desta Convenção, a tramitação de petições ou comunicações apresentadas à Comissão Interamericana de Direitos Humanos em que se alegar o desaparecimento forçado de pessoas estará sujeita aos procedimentos estabelecidos na Convenção Americana sobre Direitos Humanos e nos Estatutos e Regulamentos da Comissão e da Corte Interamericana de Direitos Humanos, inclusive as normas relativas a medidas cautelares.

\section{ARTIGO XIV}

Sem prejuízo do disposto no artigo anterior, quando a Comissão Interamericana de Direitos Humanos receber uma petição ou comunicação sobre um suposto desaparecimento forçado dirigir-se-á, por meio de sua Secretaria Executiva, de forma urgente e confidencial, ao governo pertinente, solicitando-lhe que proporcione, com a maior brevidade possível, a informação sobre o paradeiro da pessoa supostamente desaparecida e qualquer outra informação que julgar pertinente, sem que tal solicitação prejulgue a admissibilidade da petição. 


\section{ARTIGO XV}

Nada do disposto nesta Convenção será interpretado no sentido de restringir outros tratados bilaterais ou multilaterais ou outros acordos assinados entre as Partes.

Esta Convenção não se aplicará a conflitos armados internacionais regidos pelas Convenções de Genebra de 1949 e seu Protocolo relativo à proteção dos feridos, doentes e náufragos das forças armadas, e a prisioneiros e civis em tempo de guerra.

\section{ARTIGO XVI}

Esta Convenção estará aberta à assinatura dos Estados membros da Organização dos Estados Americanos.

\section{ARTIGO XVII}

Esta Convenção estará sujeita a ratificação. Os instrumentos de ratificação serão depositados na Secretaria-Geral da Organização dos Estados Americanos.

\section{ARTIGO XVIII}

Esta Convenção ficará aberta à adesão de qualquer outro Estado. Os instrumentos de adesão serão depositados na Secretaria-Geral da Organização dos Estados Americanos.

\section{ARTIGO XIX}

Os Estados poderão formular reservas a esta Convenção no momento de assiná-la, ratificá-la ou de a ela aderir, contanto que não sejam incompatíveis com o objeto e o propósito da Convenção e versem sobre uma ou mais disposições específicas.

\section{ARTIGO XX}

Esta Convenção entrará em vigor para os Estados ratificantes no trigésimo dia a partir da data em que tenha sido depositado o segundo instrumento de ratificação.

Para cada Estado que ratificar a Convenção ou a ela aderir depois de haver sido depositado o segundo instrumento de ratificação, a Convenção entrará em vigor no trigésimo dia a partir da data em que esse Estado tenha depositado seu instrumento de ratificação ou adesão.

\section{ARTIGO XXI}

Esta Convenção vigorará indefinidamente, mas qualquer dos Estados Partes poderá denunciála. O instrumento de denúncia será depositado na Secretaria-Geral da Organização dos Estados Americanos. Transcorrido um ano, contado a partir da data de depósito do 
instrumento de denúncia, a Convenção cessará em seus efeitos para o Estado denunciante, permanecendo em vigor para os demais Estados Partes.

\section{ARTIGO XXII}

O instrumento original desta Convenção, cujos textos em espanhol, francês, inglês e português são igualmente autênticos, será depositado na Secretaria-Geral da Organização dos Estados Americanos, que enviará cópia autenticada do seu texto para registro e publicação ao Secretariado das Nações Unidas, de conformidade com o artigo 102 da Carta das Nações Unidas. A Secretaria-Geral da Organização dos Estados Americanos comunicará aos Estados membros da referida Organização e aos Estados que tenham aderido à Convenção as assinaturas e os depósitos de instrumentos de ratificação, adesão e denúncia, bem como as reservas que houver.

EM FÉ DO QUE os plenipotenciários infra-assinados, devidamente autorizados por seus respectivos governos, assinam esta Convenção, que se denominará "Convenção Interamericana sobre o Desaparecimento Forçado de Pessoas".

EXPEDIDA NA CIDADE DE BELÉM, BRASIL, junho de mil novecentos e noventa e quatro.

\section{Convenção Internacional para a Proteção de Todas as Pessoas contra o Desaparecimento Forçado}

\section{Preamble}

\section{The States Parties to this Convention,}

Considering the obligation of States under the Charter of the United Nations to promote universal respect for, and observance of, human rights and fundamental freedoms,

Having regard to the Universal Declaration of Human Rights,

Recalling the International Covenant on Economic, Social and Cultural Rights, the International Covenant on Civil and Political Rights and the other relevant international instruments in the fields of human rights, humanitarian law and international criminal law, 
Also recalling the Declaration on the Protection of All Persons from Enforced Disappearance adopted by the General Assembly of the United Nations in its resolution 47/133 of 18 December 1992,

Aware of the extreme seriousness of enforced disappearance, which constitutes a crime and, in certain circumstances defined in international law, a crime against humanity,

Determined to prevent enforced disappearances and to combat impunity for the crime of enforced disappearance,

Considering the right of any person not to be subjected to enforced disappearance, the right of victims to justice and to reparation,

Affirming the right of any victim to know the truth about the circumstances of an enforced disappearance and the fate of the disappeared person, and the right to freedom to seek, receive and impart information to this end,

Have agreed on the following articles:

\section{PART I}

\section{Article 1}

1. No one shall be subjected to enforced disappearance.

2. No exceptional circumstances whatsoever, whether a state of war or a threat of war, internal political instability or any other public emergency, may be invoked as a justification for enforced disappearance.

\section{Article 2}

For the purposes of this Convention, "enforced disappearance" is considered to be the arrest, detention, abduction or any other form of deprivation of liberty by agents of the State or by persons or groups of persons acting with the authorization, support or acquiescence of the State, followed by a refusal to acknowledge the deprivation of liberty or by concealment of the fate or whereabouts of the disappeared person, which place such a person outside the protection of the law.

\section{Article 3}

Each State Party shall take appropriate measures to investigate acts defined in article 2 committed by persons or groups of persons acting without the authorization, support or acquiescence of the State and to bring those responsible to justice. 


\section{Article 4}

Each State Party shall take the necessary measures to ensure that enforced disappearance constitutes an offence under its criminal law.

\section{Article 5}

The widespread or systematic practice of enforced disappearance constitutes a crime against humanity as defined in applicable international law and shall attract the consequences provided for under such applicable international law.

\section{Article 6}

1. Each State Party shall take the necessary measures to hold criminally responsible at least:

(a) Any person who commits, orders, solicits or induces the commission of, attempts to commit, is an accomplice to or participates in an enforced disappearance;

(b) A superior who:

(i) Knew, or consciously disregarded information which clearly indicated, that subordinates under his or her effective authority and control were committing or about to commit a crime of enforced disappearance;

(ii) Exercised effective responsibility for and control over activities which were concerned with the crime of enforced disappearance; and

(iii) Failed to take all necessary and reasonable measures within his or her power to prevent or repress the commission of an enforced disappearance or to submit the matter to the competent authorities for investigation and prosecution;

(c) Subparagraph (b) above is without prejudice to the higher standards of responsibility applicable under relevant international law to a military commander or to a person effectively acting as a military commander.

2. No order or instruction from any public authority, civilian, military or other, may be invoked to justify an offence of enforced disappearance.

\section{Article 7}

1. Each State Party shall make the offence of enforced disappearance punishable by appropriate penalties which take into account its extreme seriousness.

2. Each State Party may establish: 
(a) Mitigating circumstances, in particular for persons who, having been implicated in the commission of an enforced disappearance, effectively contribute to bringing the disappeared person forward alive or make it possible to clarify cases of enforced disappearance or to identify the perpetrators of an enforced disappearance;

(b) Without prejudice to other criminal procedures, aggravating circumstances, in particular in the event of the death of the disappeared person or the commission of an enforced disappearance in respect of pregnant women, minors, persons with disabilities or other particularly vulnerable persons.

\section{Article 8}

Without prejudice to article 5,

1. A State Party which applies a statute of limitations in respect of enforced disappearance shall take the necessary measures to ensure that the term of limitation for criminal proceedings:

(a) Is of long duration and is proportionate to the extreme seriousness of this offence;

(b) Commences from the moment when the offence of enforced disappearance ceases, taking into account its continuous nature.

2. Each State Party shall guarantee the right of victims of enforced disappearance to an effective remedy during the term of limitation.

\section{Article 9}

1. Each State Party shall take the necessary measures to establish its competence to exercise jurisdiction over the offence of enforced disappearance:

(a) When the offence is committed in any territory under its jurisdiction or on board a ship or aircraft registered in that State;

(b) When the alleged offender is one of its nationals;

(c) When the disappeared person is one of its nationals and the State Party considers it appropriate.

2. Each State Party shall likewise take such measures as may be necessary to establish its competence to exercise jurisdiction over the offence of enforced disappearance when the alleged offender is present in any territory under its jurisdiction, unless it extradites or surrenders him or her to another State in accordance with its international obligations or 
surrenders him or her to an international criminal tribunal whose jurisdiction it has recognized.

3. This Convention does not exclude any additional criminal jurisdiction exercised in accordance with national law.

\section{Article 10}

1. Upon being satisfied, after an examination of the information available to it, that the circumstances so warrant, any State Party in whose territory a person suspected of having committed an offence of enforced disappearance is present shall take him or her into custody or take such other legal measures as are necessary to ensure his or her presence. The custody and other legal measures shall be as provided for in the law of that State Party but may be maintained only for such time as is necessary to ensure the person's presence at criminal, surrender or extradition proceedings.

2. A State Party which has taken the measures referred to in paragraph 1 of this article shall immediately carry out a preliminary inquiry or investigations to establish the facts. It shall notify the States Parties referred to in article 9, paragraph 1, of the measures it has taken in pursuance of paragraph 1 of this article, including detention and the circumstances warranting detention, and of the findings of its preliminary inquiry or its investigations, indicating whether it intends to exercise its jurisdiction.

3. Any person in custody pursuant to paragraph 1 of this article may communicate immediately with the nearest appropriate representative of the State of which he or she is a national, or, if he or she is a stateless person, with the representative of the State where he or she usually resides.

\section{Article 11}

1. The State Party in the territory under whose jurisdiction a person alleged to have committed an offence of enforced disappearance is found shall, if it does not extradite that person or surrender him or her to another State in accordance with its international obligations or surrender him or her to an international criminal tribunal whose jurisdiction it has recognized, submit the case to its competent authorities for the purpose of prosecution.

2. These authorities shall take their decision in the same manner as in the case of any ordinary offence of a serious nature under the law of that State Party. In the cases referred to in article 
9, paragraph 2, the standards of evidence required for prosecution and conviction shall in no way be less stringent than those which apply in the cases referred to in article 9, paragraph 1 .

3. Any person against whom proceedings are brought in connection with an offence of enforced disappearance shall be guaranteed fair treatment at all stages of the proceedings. Any person tried for an offence of enforced disappearance shall benefit from a fair trial before a competent, independent and impartial court or tribunal established by law.

\section{Article 12}

1. Each State Party shall ensure that any individual who alleges that a person has been subjected to enforced disappearance has the right to report the facts to the competent authorities, which shall examine the allegation promptly and impartially and, where necessary, undertake without delay a thorough and impartial investigation. Appropriate steps shall be taken, where necessary, to ensure that the complainant, witnesses, relatives of the disappeared person and their defence counsel, as well as persons participating in the investigation, are protected against all ill-treatment or intimidation as a consequence of the complaint or any evidence given.

2. Where there are reasonable grounds for believing that a person has been subjected to enforced disappearance, the authorities referred to in paragraph 1 of this article shall undertake an investigation, even if there has been no formal complaint.

3. Each State Party shall ensure that the authorities referred to in paragraph 1 of this article:

(a) Have the necessary powers and resources to conduct the investigation effectively, including access to the documentation and other information relevant to their investigation;

(b) Have access, if necessary with the prior authorization of a judicial authority, which shall rule promptly on the matter, to any place of detention or any other place where there are reasonable grounds to believe that the disappeared person may be present.

4. Each State Party shall take the necessary measures to prevent and sanction acts that hinder the conduct of an investigation. It shall ensure in particular that persons suspected of having committed an offence of enforced disappearance are not in a position to influence the progress of an investigation by means of pressure or acts of intimidation or reprisal aimed at the complainant, witnesses, relatives of the disappeared person or their defence counsel, or at persons participating in the investigation.

\section{Article 13}


1. For the purposes of extradition between States Parties, the offence of enforced disappearance shall not be regarded as a political offence or as an offence connected with a political offence or as an offence inspired by political motives. Accordingly, a request for extradition based on such an offence may not be refused on these grounds alone.

2. The offence of enforced disappearance shall be deemed to be included as an extraditable offence in any extradition treaty existing between States Parties before the entry into force of this Convention.

3. States Parties undertake to include the offence of enforced disappearance as an extraditable offence in any extradition treaty subsequently to be concluded between them.

4. If a State Party which makes extradition conditional on the existence of a treaty receives a request for extradition from another State Party with which it has no extradition treaty, it may consider this Convention as the necessary legal basis for extradition in respect of the offence of enforced disappearance.

5. States Parties which do not make extradition conditional on the existence of a treaty shall recognize the offence of enforced disappearance as an extraditable offence between themselves.

6. Extradition shall, in all cases, be subject to the conditions provided for by the law of the requested State Party or by applicable extradition treaties, including, in particular, conditions relating to the minimum penalty requirement for extradition and the grounds upon which the requested State Party may refuse extradition or make it subject to certain conditions.

7. Nothing in this Convention shall be interpreted as imposing an obligation to extradite if the requested State Party has substantial grounds for believing that the request has been made for the purpose of prosecuting or punishing a person on account of that person's sex, race, religion, nationality, ethnic origin, political opinions or membership of a particular social group, or that compliance with the request would cause harm to that person for any one of these reasons.

Article 14

1. States Parties shall afford one another the greatest measure of mutual legal assistance in connection with criminal proceedings brought in respect of an offence of enforced disappearance, including the supply of all evidence at their disposal that is necessary for the proceedings. 
2. Such mutual legal assistance shall be subject to the conditions provided for by the domestic law of the requested State Party or by applicable treaties on mutual legal assistance, including, in particular, the conditions in relation to the grounds upon which the requested State Party may refuse to grant mutual legal assistance or may make it subject to conditions.

\section{Article 15}

States Parties shall cooperate with each other and shall afford one another the greatest measure of mutual assistance with a view to assisting victims of enforced disappearance, and in searching for, locating and releasing disappeared persons and, in the event of death, in exhuming and identifying them and returning their remains.

\section{Article 16}

1. No State Party shall expel, return ("refouler"), surrender or extradite a person to another State where there are substantial grounds for believing that he or she would be in danger of being subjected to enforced disappearance.

2. For the purpose of determining whether there are such grounds, the competent authorities shall take into account all relevant considerations, including, where applicable, the existence in the State concerned of a consistent pattern of gross, flagrant or mass violations of human rights or of serious violations of international humanitarian law.

\section{Article 17}

1. No one shall be held in secret detention.

2. Without prejudice to other international obligations of the State Party with regard to the deprivation of liberty, each State Party shall, in its legislation:

(a) Establish the conditions under which orders of deprivation of liberty may be given;

(b) Indicate those authorities authorized to order the deprivation of liberty;

(c) Guarantee that any person deprived of liberty shall be held solely in officially recognized and supervised places of deprivation of liberty;

(d) Guarantee that any person deprived of liberty shall be authorized to communicate with and be visited by his or her family, counsel or any other person of his or her choice, subject only to the conditions established by law, or, if he or she is a foreigner, to communicate with his or her consular authorities, in accordance with applicable international law; 
(e) Guarantee access by the competent and legally authorized authorities and institutions to the places where persons are deprived of liberty, if necessary with prior authorization from a judicial authority;

(f) Guarantee that any person deprived of liberty or, in the case of a suspected enforced disappearance, since the person deprived of liberty is not able to exercise this right, any persons with a legitimate interest, such as relatives of the person deprived of liberty, their representatives or their counsel, shall, in all circumstances, be entitled to take proceedings before a court, in order that the court may decide without delay on the lawfulness of the deprivation of liberty and order the person's release if such deprivation of liberty is not lawful.

3. Each State Party shall assure the compilation and maintenance of one or more up-to-date official registers and/or records of persons deprived of liberty, which shall be made promptly available, upon request, to any judicial or other competent authority or institution authorized for that purpose by the

law of the State Party concerned or any relevant international legal instrument to which the State concerned is a party. The information contained therein shall include, as a minimum:

(a) The identity of the person deprived of liberty;

(b) The date, time and place where the person was deprived of liberty and the identity of the authority that deprived the person of liberty;

(c) The authority that ordered the deprivation of liberty and the grounds for the deprivation of liberty;

(d) The authority responsible for supervising the deprivation of liberty;

(e) The place of deprivation of liberty, the date and time of admission to the place of deprivation of liberty and the authority responsible for the place of deprivation of liberty;

(f) Elements relating to the state of health of the person deprived of liberty;

(g) In the event of death during the deprivation of liberty, the circumstances and cause of death and the destination of the remains;

(h) The date and time of release or transfer to another place of detention, the destination and the authority responsible for the transfer.

Article 18 
1. Subject to articles 19 and 20, each State Party shall guarantee to any person with a legitimate interest in this information, such as relatives of the person deprived of liberty, their representatives or their counsel, access to at least the following information:

(a) The authority that ordered the deprivation of liberty;

(b) The date, time and place where the person was deprived of liberty and admitted to the place of deprivation of liberty;

(c) The authority responsible for supervising the deprivation of liberty;

(d) The whereabouts of the person deprived of liberty, including, in the event of a transfer to another place of deprivation of liberty, the destination and the authority responsible for the transfer;

(e) The date, time and place of release;

(f) Elements relating to the state of health of the person deprived of liberty;

(g) In the event of death during the deprivation of liberty, the circumstances and cause of death and the destination of the remains.

2. Appropriate measures shall be taken, where necessary, to protect the persons referred to in paragraph 1 of this article, as well as persons participating in the investigation, from any illtreatment, intimidation or sanction as a result of the search for information concerning a person deprived of liberty.

\section{Article 19}

1. Personal information, including medical and genetic data, which is collected and/or transmitted within the framework of the search for a disappeared person shall not be used or made available for purposes other than the search for the disappeared person. This is without prejudice to the use of such information in criminal proceedings relating to an offence of enforced disappearance or the exercise of the right to obtain reparation.

2. The collection, processing, use and storage of personal information, including medical and genetic data, shall not infringe or have the effect of infringing the human rights, fundamental freedoms or human dignity of an individual.

\section{Article 20}

1. Only where a person is under the protection of the law and the deprivation of liberty is subject to judicial control may the right to information referred to in article 18 be restricted, 
on an exceptional basis, where strictly necessary and where provided for by law, and if the transmission of the information would adversely affect the privacy or safety of the person, hinder a criminal investigation, or for other equivalent reasons in accordance with the law, and in conformity with applicable international law and with the objectives of this Convention. In no case shall there be restrictions on the right to information referred to in article 18 that could constitute conduct defined in article 2 or be in violation of article 17 , paragraph 1.

2. Without prejudice to consideration of the lawfulness of the deprivation of a person's liberty, States Parties shall guarantee to the persons referred to in article 18, paragraph 1, the right to a prompt and effective judicial remedy as a means of obtaining without delay the information referred to in article 18, paragraph 1 . This right to a remedy may not be suspended or restricted in any circumstances.

\section{Article 21}

Each State Party shall take the necessary measures to ensure that persons deprived of liberty are released in a manner permitting reliable verification that they have actually been released. Each State Party shall also take the necessary measures to assure the physical integrity of such persons and their ability to exercise fully their rights at the time of release, without prejudice to any obligations to which such persons may be subject under national law.

\section{Article 22}

Without prejudice to article 6, each State Party shall take the necessary measures to prevent and impose sanctions for the following conduct:

(a) Delaying or obstructing the remedies referred to in article 17, paragraph $2(f)$, and article 20, paragraph 2;

(b) Failure to record the deprivation of liberty of any person, or the recording of any information which the official responsible for the official register knew or should have known to be inaccurate;

(c) Refusal to provide information on the deprivation of liberty of a person, or the provision of inaccurate information, even though the legal requirements for providing such information have been met.

Article 23 
1. Each State Party shall ensure that the training of law enforcement personnel, civil or military, medical personnel, public officials and other persons who may be involved in the custody or treatment of any person deprived of liberty includes the necessary education and information regarding the relevant provisions of this Convention, in order to:

(a) Prevent the involvement of such officials in enforced disappearances;

(b) Emphasize the importance of prevention and investigations in relation to enforced disappearances;

(c) Ensure that the urgent need to resolve cases of enforced disappearance is recognized.

2. Each State Party shall ensure that orders or instructions prescribing, authorizing or encouraging enforced disappearance are prohibited. Each State Party shall guarantee that a person who refuses to obey such an order will not be punished.

3. Each State Party shall take the necessary measures to ensure that the persons referred to in paragraph 1 of this article who have reason to believe that an enforced disappearance has occurred or is planned report the matter to their superiors and, where necessary, to the appropriate authorities or bodies vested with powers of review or remedy.

\section{Article 24}

1. For the purposes of this Convention, "victim" means the disappeared person and any individual who has suffered harm as the direct result of an enforced disappearance.

2. Each victim has the right to know the truth regarding the circumstances of the enforced disappearance, the progress and results of the investigation and the fate of the disappeared person. Each State Party shall take appropriate measures in this regard.

3. Each State Party shall take all appropriate measures to search for, locate and release disappeared persons and, in the event of death, to locate, respect and return their remains.

4. Each State Party shall ensure in its legal system that the victims of enforced disappearance have the right to obtain reparation and prompt, fair and adequate compensation.

5. The right to obtain reparation referred to in paragraph 4 of this article covers material and moral damages and, where appropriate, other forms of reparation such as:

(a) Restitution;

(b) Rehabilitation; 
(c) Satisfaction, including restoration of dignity and reputation;

(d) Guarantees of non-repetition.

6. Without prejudice to the obligation to continue the investigation until the fate of the disappeared person has been clarified, each State Party shall take the appropriate steps with regard to the legal situation of disappeared persons whose fate has not been clarified and that of their relatives, in fields such as social welfare, financial matters, family law and property rights.

7. Each State Party shall guarantee the right to form and participate freely in organizations and associations concerned with attempting to establish the circumstances of enforced disappearances and the fate of disappeared persons, and to assist victims of enforced disappearance.

\section{Article 25}

1. Each State Party shall take the necessary measures to prevent and punish under its criminal law:

(a) The wrongful removal of children who are subjected to enforced disappearance, children whose father, mother or legal guardian is subjected to enforced disappearance or children born during the captivity of a mother subjected to enforced disappearance;

(b) The falsification, concealment or destruction of documents attesting to the true identity of the children referred to in subparagraph $(a)$ above.

2. Each State Party shall take the necessary measures to search for and identify the children referred to in paragraph $1(a)$ of this article and to return them to their families of origin, in accordance with legal procedures and applicable international agreements.

3. States Parties shall assist one another in searching for, identifying and locating the children referred to in paragraph $1(a)$ of this article.

4. Given the need to protect the best interests of the children referred to in paragraph $1(a)$ of this article and their right to preserve, or to have re-established, their identity, including their nationality, name and family relations as recognized by law, States Parties which recognize a system of adoption or other form of placement of children shall have legal procedures in place to review the adoption or placement procedure, and, where appropriate, to annul any adoption or placement of children that originated in an enforced disappearance. 
5. In all cases, and in particular in all matters relating to this article, the best interests of the child shall be a primary consideration, and a child who is capable of forming his or her own views shall have the right to express those views freely, the views of the child being given due weight in accordance with the age and maturity of the child.

PART II

Article 26

1. A Committee on Enforced Disappearances (hereinafter referred to as "the Committee") shall be established to carry out the functions provided for under this Convention. The Committee shall consist of ten experts of high moral character and recognized competence in the field of human rights, who shall serve in their personal capacity and be independent and impartial. The members of the Committee shall be elected by the States Parties according to equitable geographical distribution. Due account shall be taken of the usefulness of the participation in the work of the Committee of persons having relevant legal experience and of balanced gender representation.

2. The members of the Committee shall be elected by secret ballot from a list of persons nominated by States Parties from among their nationals, at biennial meetings of the States Parties convened by the Secretary-General of the United Nations for this purpose. At those meetings, for which two thirds of the States Parties shall constitute a quorum, the persons elected to the Committee shall be those who obtain the largest number of votes and an absolute majority of the votes of the representatives of States Parties present and voting.

3. The initial election shall be held no later than six months after the date of entry into force of this Convention. Four months before the date of each election, the Secretary-General of the United Nations shall address a letter to the States Parties inviting them to submit nominations within three months. The Secretary-General shall prepare a list in alphabetical order of all persons thus nominated, indicating the State Party which nominated each candidate, and shall submit this list to all States Parties.

4. The members of the Committee shall be elected for a term of four years. They shall be eligible for re-election once. However, the term of five of the members elected at the first election shall expire at the end of two years; immediately after the first election, the names of these five members shall be chosen by lot by the chairman of the meeting referred to in paragraph 2 of this article. 
5. If a member of the Committee dies or resigns or for any other reason can no longer perform his or her Committee duties, the State Party which nominated him or her shall, in accordance with the criteria set out in paragraph 1 of this article, appoint another candidate from among its nationals to serve out his or her term, subject to the approval of the majority of the States Parties. Such approval shall be considered to have been obtained unless half or more of the States Parties respond negatively within six weeks of having been informed by the SecretaryGeneral of the United Nations of the proposed appointment.

6. The Committee shall establish its own rules of procedure.

7. The Secretary-General of the United Nations shall provide the Committee with the necessary means, staff and facilities for the effective performance of its functions. The Secretary-General of the United Nations shall convene the initial meeting of the Committee.

8. The members of the Committee shall be entitled to the facilities, privileges and immunities of experts on mission for the United Nations, as laid down in the relevant sections of the Convention on the Privileges and Immunities of the United Nations.

9. Each State Party shall cooperate with the Committee and assist its members in the fulfilment of their mandate, to the extent of the Committee's functions that the State Party has accepted.

\section{Article 27}

A Conference of the States Parties will take place at the earliest four years and at the latest six years following the entry into force of this Convention to evaluate the functioning of the Committee and to decide, in accordance with the procedure described in article 44, paragraph 2 , whether it is appropriate to transfer to another body - without excluding any possibility the monitoring of this Convention, in accordance with the functions defined in articles 28 to 36.

\section{Article 28}

1. In the framework of the competencies granted by this Convention, the Committee shall cooperate with all relevant organs, offices and specialized agencies and funds of the United Nations, with the treaty bodies instituted by international instruments, with the special procedures of the United Nations and with the relevant regional intergovernmental organizations or bodies, as well as with all relevant State institutions, agencies or offices working towards the protection of all persons against enforced disappearances. 
2. As it discharges its mandate, the Committee shall consult other treaty bodies instituted by relevant international human rights instruments, in particular the Human Rights Committee instituted by the International Covenant on Civil and Political Rights, with a view to ensuring the consistency of their respective observations and recommendations.

Article 29

1. Each State Party shall submit to the Committee, through the Secretary-General of the United Nations, a report on the measures taken to give effect to its obligations under this Convention, within two years after the entry into force of this Convention for the State Party concerned.

2. The Secretary-General of the United Nations shall make this report available to all States Parties.

3. Each report shall be considered by the Committee, which shall issue such comments, observations or recommendations as it may deem appropriate. The comments, observations or recommendations shall be communicated to the State Party concerned, which may respond to them, on its own initiative or at the request of the Committee.

4. The Committee may also request States Parties to provide additional information on the implementation of this Convention.

Article 30

1. A request that a disappeared person should be sought and found may be submitted to the Committee, as a matter of urgency, by relatives of the disappeared person or their legal representatives, their counsel or any person authorized by them, as well as by any other person having a legitimate interest.

2. If the Committee considers that a request for urgent action submitted in pursuance of paragraph 1 of this article:

(a) Is not manifestly unfounded;

(b) Does not constitute an abuse of the right of submission of such requests;

(c) Has already been duly presented to the competent bodies of the State Party concerned, such as those authorized to undertake investigations, where such a possibility exists;

(d) Is not incompatible with the provisions of this Convention; and 
(e) The same matter is not being examined under another procedure of international investigation or settlement of the same nature;

it shall request the State Party concerned to provide it with information on the situation of the persons sought, within a time limit set by the Committee.

3. In the light of the information provided by the State Party concerned in accordance with paragraph 2 of this article, the Committee may transmit recommendations to the State Party, including a request that the State Party should take all the necessary measures, including interim measures, to locate and protect the person concerned in accordance with this Convention and to inform the Committee, within a specified period of time, of measures taken, taking into account the urgency of the situation. The Committee shall inform the person submitting the urgent action request of its recommendations and of the information provided to it by the State as it becomes available.

4. The Committee shall continue its efforts to work with the State Party concerned for as long as the fate of the person sought remains unresolved. The person presenting the request shall be kept informed.

Article 31

1. A State Party may at the time of ratification of this Convention or at any time afterwards declare that it recognizes the competence of the Committee to receive and consider communications from or on behalf of individuals subject to its jurisdiction claiming to be victims of a violation by this State Party of provisions of this Convention. The Committee shall not admit any communication concerning a State Party which has not made such a declaration.

2. The Committee shall consider a communication inadmissible where:

(a) The communication is anonymous;

(b) The communication constitutes an abuse of the right of submission of such communications or is incompatible with the provisions of this Convention;

(c) The same matter is being examined under another procedure of international investigation or settlement of the same nature; or where

(d) All effective available domestic remedies have not been exhausted. This rule shall not apply where the application of the remedies is unreasonably prolonged. 
3. If the Committee considers that the communication meets the requirements set out in paragraph 2 of this article, it shall transmit the communication to the State Party concerned, requesting it to provide observations and comments within a time limit set by the Committee.

4. At any time after the receipt of a communication and before a determination on the merits has been reached, the Committee may transmit to the State Party concerned for its urgent consideration a request that the State Party will take such interim measures as may be necessary to avoid possible irreparable damage to the victims of the alleged violation. Where the Committee exercises its discretion, this does not imply a determination on admissibility or on the merits of the communication.

5. The Committee shall hold closed meetings when examining communications under the present article. It shall inform the author of a communication of the responses provided by the State Party concerned. When the Committee decides to finalize the procedure, it shall communicate its views to the State Party and to the author of the communication.

\section{Article 32}

A State Party to this Convention may at any time declare that it recognizes the competence of the Committee to receive and consider communications in which a State Party claims that another State Party is not fulfilling its obligations under this Convention. The Committee shall not receive communications concerning a State Party which has not made such a declaration, nor communications from a State Party which has not made such a declaration.

\section{Article 33}

1. If the Committee receives reliable information indicating that a State Party is seriously violating the provisions of this Convention, it may, after consultation with the State Party concerned, request one or more of its members to undertake a visit and report back to it without delay.

2. The Committee shall notify the State Party concerned, in writing, of its intention to organize a visit, indicating the composition of the delegation and the purpose of the visit. The State Party shall answer the Committee within a reasonable time.

3. Upon a substantiated request by the State Party, the Committee may decide to postpone or cancel its visit. 
4. If the State Party agrees to the visit, the Committee and the State Party concerned shall work together to define the modalities of the visit and the State Party shall provide the Committee with all the facilities needed for the successful completion of the visit.

5. Following its visit, the Committee shall communicate to the State Party concerned its observations and recommendations.

\section{Article 34}

If the Committee receives information which appears to it to contain well-founded indications that enforced disappearance is being practised on a widespread or systematic basis in the territory under the jurisdiction of a State Party, it may, after seeking from the State Party concerned all relevant information on the situation, urgently bring the matter to the attention of the General Assembly of the United Nations, through the Secretary-General of the United Nations.

\section{Article 35}

1. The Committee shall have competence solely in respect of enforced disappearances which commenced after the entry into force of this Convention.

2. If a State becomes a party to this Convention after its entry into force, the obligations of that State vis-à-vis the Committee shall relate only to enforced disappearances which commenced after the entry into force of this Convention for the State concerned.

\section{Article 36}

1. The Committee shall submit an annual report on its activities under this Convention to the States Parties and to the General Assembly of the United Nations.

2. Before an observation on a State Party is published in the annual report, the State Party concerned shall be informed in advance and shall be given reasonable time to answer. This State Party may request the publication of its comments or observations in the report.

\section{PART III}

\section{Article 37}

Nothing in this Convention shall affect any provisions which are more conducive to the protection of all persons from enforced disappearance and which may be contained in:

(a) The law of a State Party; 
(b) International law in force for that State.

Article 38

1. This Convention is open for signature by all Member States of the United Nations.

2. This Convention is subject to ratification by all Member States of the United Nations. Instruments of ratification shall be deposited with the Secretary-General of the United Nations.

3. This Convention is open to accession by all Member States of the United Nations. Accession shall be effected by the deposit of an instrument of accession with the SecretaryGeneral.

Article 39

1. This Convention shall enter into force on the thirtieth day after the date of deposit with the Secretary-General of the United Nations of the twentieth instrument of ratification or accession.

2. For each State ratifying or acceding to this Convention after the deposit of the twentieth instrument of ratification or accession, this Convention shall enter into force on the thirtieth day after the date of the deposit of that State's instrument of ratification or accession.

\section{Article 40}

The Secretary-General of the United Nations shall notify all States Members of the United Nations and all States which have signed or acceded to this Convention of the following:

(a) Signatures, ratifications and accessions under article 38;

(b) The date of entry into force of this Convention under article 39.

\section{Article 41}

The provisions of this Convention shall apply to all parts of federal States without any limitations or exceptions.

\section{Article 42}

1. Any dispute between two or more States Parties concerning the interpretation or application of this Convention which cannot be settled through negotiation or by the procedures expressly provided for in this Convention shall, at the request of one of them, be submitted to arbitration. If within six months from the date of the request for arbitration the Parties are 
unable to agree on the organization of the arbitration, any one of those Parties may refer the dispute to the International Court of Justice by request in conformity with the Statute of the Court.

2. A State may, at the time of signature or ratification of this Convention or accession thereto, declare that it does not consider itself bound by paragraph 1 of this article. The other States Parties shall not be bound by paragraph 1 of this article with respect to any State Party having made such a declaration.

3. Any State Party having made a declaration in accordance with the provisions of paragraph 2 of this article may at any time withdraw this declaration by notification to the SecretaryGeneral of the United Nations.

\section{Article 43}

This Convention is without prejudice to the provisions of international humanitarian law, including the obligations of the High Contracting Parties to the four Geneva Conventions of 12 August 1949 and the two Additional Protocols thereto of 8 June 1977, or to the opportunity available to any State Party to authorize the International Committee of the Red Cross to visit places of detention in situations not covered by international humanitarian law.

\section{Article 44}

1. Any State Party to this Convention may propose an amendment and file it with the Secretary-General of the United Nations. The Secretary-General shall thereupon communicate the proposed amendment to the States Parties to this Convention with a request that they indicate whether they favour a conference of States Parties for the purpose of considering and voting upon the proposal. In the event that within four months from the date of such communication at least one third of the States Parties favour such a conference, the SecretaryGeneral shall convene the conference under the auspices of the United Nations.

2. Any amendment adopted by a majority of two thirds of the States Parties present and voting at the conference shall be submitted by the Secretary-General of the United Nations to all the States Parties for acceptance.

3. An amendment adopted in accordance with paragraph 1 of this article shall enter into force when two thirds of the States Parties to this Convention have accepted it in accordance with their respective constitutional processes. 
4. When amendments enter into force, they shall be binding on those States Parties which have accepted them, other States Parties still being bound by the provisions of this Convention and any earlier amendment which they have accepted.

Article 45

1. This Convention, of which the Arabic, Chinese, English, French, Russian and Spanish texts are equally authentic, shall be deposited with the Secretary-General of the United Nations.

2. The Secretary-General of the United Nations shall transmit certified copies of this Convention to all States referred to in article 38. 